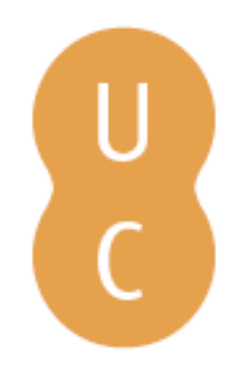

\title{
pompalina
}

\section{A dimensão anti-épica de Virgílio e o indianismo de Gonçalves Dias}

Autor(es): $\quad$ Grizoste, Weberson Fernandes Publicado por: Centro de Estudos Clássicos e Humanísticos; Imprensa da Universidade

URL

persistente: URI:http://hdl.handle.net/10316.2/2385

DOI: $\quad$ DOI:http://dx.doi.org/10.14195/978-989-8281-90-6

Accessed : $\quad$ 26-Apr-2023 00:58:56

A navegação consulta e descarregamento dos títulos inseridos nas Bibliotecas Digitais UC Digitalis, UC Pombalina e UC Impactum, pressupõem a aceitação plena e sem reservas dos Termos e Condições de Uso destas Bibliotecas Digitais, disponíveis em https://digitalis.uc.pt/pt-pt/termos.

Conforme exposto nos referidos Termos e Condições de Uso, o descarregamento de títulos de acesso restrito requer uma licença válida de autorização devendo o utilizador aceder ao(s) documento(s) a partir de um endereço de IP da instituição detentora da supramencionada licença.

Ao utilizador é apenas permitido o descarregamento para uso pessoal, pelo que o emprego do(s) título(s) descarregado(s) para outro fim, designadamente comercial, carece de autorização do respetivo autor ou editor da obra.

Na medida em que todas as obras da UC Digitalis se encontram protegidas pelo Código do Direito de Autor e Direitos Conexos e demais legislação aplicável, toda a cópia, parcial ou total, deste documento, nos casos em que é legalmente admitida, deverá conter ou fazer-se acompanhar por este aviso.

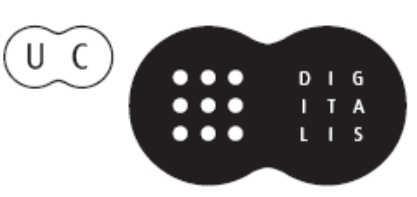




\section{a dimensão anti-épica de Virgílio e o indianismo de Gonçalves Dias}

Weberson Fernandes Grizoste 


\section{Weberson Fernandes Grizoste}

(Universidade de Coimbra)

\section{A dimensão anti-épica de Virgílio e o indianismo de Gonçalves Dias}


Todos os volumes desta série são sujeitos a arbitragem científica independente.

Autor: Weberson Fernandes Grizoste

Título: A dimensão anti-épica de Virgílio e o indianismo de Gonçalves Dias

Editor: Centro de Estudos Clássicos e Humanísticos

Imprensa da Universidade de Coimbra

Edição: 1a/2011

Coordenador Científico do Plano de Edição: Maria do Céu Fialho

Conselho Editorial: José Ribeiro Ferreira, Maria de Fátima Silva,

Francisco de Oliveira, Nair Castro Soares

Director técnico da colecção: Delfim F. Leâo

Concepção gráfica e paginação: Rodolfo Lopes, Nelson Ferreira.

Obra realizada no âmbito das actividades da UI\&D

Centro de Estudos Clássicos e Humanísticos

Univ ersidade de Coimbra

Faculdade de Letras

Tel.: 239859981 | Fax: 239836733

3000-447 Coimbra

ISBN: 978-989-8281-89-0

ISBN Digital: 978-989-8281-90-6

DOI: http://dx.doi.org/10.14195/978-989-8281-90-6

Depósito Legal: 328942/11

Obra Publicada com o Apoio de:

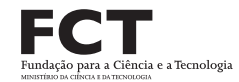

$\mathrm{POCI} / 2010$

(C) IMPRENSA DA UnIVERSIDAdE DE COIMBRA

(C) Classica Digitalia Vniversitatis Conimbrigensis (http://classicadigitalia.uc.pt)

(C) Centro de Estudos Clássicos e Humanísticos da Universidade de Coimbra

Reservados todos os direitos. Nos termos legais fica expressamente proibida a reprodução total ou parcial por qualquer meio, em papel ou em edição electrónica, sem autorização expressa dos titulares dos direitos. É desde já excepcionada a utilização em circuitos académicos fechados para apoio a leccionação ou extensão cultural por via de e-learning. 


\section{ÍNDICE}

Nota Pr évia 9

$\begin{array}{ll}\text { Prefácio } & 11\end{array}$

Carlos Ascenso André

$\begin{array}{ll}\text { Abr eviaturas e Sigl as } & 15\end{array}$

$\begin{array}{ll}\text { Intr oduçã o } & 17\end{array}$

Capítul o I - Epopeia e Antiepop eia: A intençã o e o r esul tado 23

Capítul o II - Vir gílio: as c ontradiç óes de um poet a épico 31

Capítul o III - Gonçal ves Dias: as c ontradiç óes de um poet a anti-ép ico 45

1. A procura do $r$ epresent ante da na ção brasileir a 47

2. A contradiçã o da dialética gonçal vina 53

3. Tabira: o r etra to da uniã o entr e o índio e o eur opeu 64

4. Guerr eir os: r etra tos de uma civiliz açã o per dida 87

5. O que há-de ser mor to e que é digno de ser mor to 105

6. Tupá: o parado xo de Gonçal ves Dias 131

7. A estiliz ação nost ál gica da quil o que nã o se deixa mais cant ar $\quad 150$

$\begin{array}{lr}\text { Considera ções finais } & 189\end{array}$

$\begin{array}{ll}\text { Bibliografia } & 195\end{array}$ 
À memória dos meus avós desbravadores do invio sertão 


\section{Nota Prévia}

Esta obra é o resultado do liame de três vertentes, com obviedade não há torrente sem fonte. Gonçalves Dias veio através da Professora Vera Cruz Maciel, Virgílio através da Doutora Inês Parolin Almeida e o antiépico através do Doutor Carlos Ascenso André.

Quando entrei em contato com a poética antiépica de Virgílio vi, - depois de algum esforço - refle os no indianismo de Gonçalves Dias. Os primeiros estranhamentos trouxeram resultados favoráveis que ainda estáo a decorrer. Aqui disponibilizamos a primeira parte concluída desta pesquisa como parte dos requisitos para a conclusão do curso de Mestrado em Poética e Hermenêutica. A segunda virá em curso homónimo em doutoramento sob o título de Os paradoxos antiépicos da Ilíada Brasileira.

Como resultado que compete, dedico e agradeço ao Doutor Carlos Ascenso André, porque terei sempre a honra de o ter tido como orientador, porque acreditando na possibilidade da realização deste trabalho tornou-se-me um exemplo do ofício e comprometimento que compete à docência.

Gostaria de externar também a minha gratidão ao Professor Doutor Francisco de Oliveira pela hombridade de uma arbitrariedade bastante zelosa que sem sombras de dúvidas corrigiu muitas lacunas que me passaram a esmo.

À Doutora Margarida Miranda pela generosidade do apuramento desta obra, cujo auxílio enriqueceu imensamente no que compete à gramática e ao léxico da língua.

Ao Doutor Delfim Ferreira Leão por se ter disponibilizado sem reservas tanto quanto precisei, desde as orientaçóes ao prelo e ainda no que diz respeito às exigências da polidez.

À Doutora Maria do Céu Fialho por se ter prontificado todas as vezes que precisei, cujo auxílio foi imprescindível na minha continuidade por este viés.

Pela revisão textual e inúmeras contribuições singulares da $\mathrm{Dr}^{\mathrm{a}}$. Ana Seiça Carvalho. A atenção da D. Custódia Morgado André na época do levantamento bibliográfico desta obra. 
As orientaçôes de prelo do Dr. Nelson Henrique Ferreira e o carisma dos demais membros do Instituto com os quais convivo diariamente.

Agradeço ainda aos meus pais José Fernandes e Lenilda Grizoste e às minhas irmãs Josiane Cristina e Josilâine Patrícia porque me ajudaram a suportar a saudade do Mato Grosso.

Obviamente que as contribuiçôes indiretas para o início, confecção, apuramento e conclusão deste projeto abarcam inúmeras pessoas. Ser-me-ia impossível citá-las todas aqui, escusando-me apenas em agradecer a todas aquelas que se sintam envolvidas.

Coimbra, Maio de 2011. 


\section{Prefácio}

Ao nascer, já o poeta trazia agarrada à pele a semente de todos os seus paradoxos; e dela se náo desapegou ao longo das suas pouco mais de quatro décadas de vida, antes a viu desabrochar, flo escer, lançar fundas raízes. Filho de um português e de uma mestiça (uma guajajara, como na "Introdução" deste volume se diz), essa origem ter-lhe-á ditado, porventura, o dilema em que se debateu, qual beco sem saída, Gonçalves Dias, um dos mais notáveis poetas do Brasil e um nome maior do Romantismo brasileiro.

À sua origem paterna junta-se o facto de ter sido na Europa, mais concretamente em Portugal, que formou a sua personalidade literária, com fortes raízes clássicas. Mas sentia, parece, o sangue indígena a correr-lhe nas veias e uma alma indígena a pulsar-lhe bem fundo. Observador atento do país que o viu nascer e que, afinal, nasceu com ele (veio ao mundo pouco depois da independência), forjou nessa encruzilhada de destinos e nas contradiçóes que nela pressentia a sua personalidade.

Assim se foi nele configurando o seu indianismo, plasmado em versos de um lirismo ímpar e numa escrita que obedecia aos mais genuínos cânones da poesia clássica e europeia.

Olhou o "seu" povo e a "sua" terra; e olhou o português, essa outra raiz de onde vinha, fundador do país e da nacionalidade e, ao mesmo tempo, portanto, libertador e colonizador desse mesmo povo e dessa mesma terra. E, na hora da escolha, pesou mais o húmus, o mesmo é dizer, a sua alma brasileira, mesclada de sangues e de raças, mas fiel à fo ça da terra-máe.

Aí lhe terá nascido, por certo, o impulso de celebrar o índio do Brasil (índio lhe chamaremos, por comodidade e tradição, mas com a consciência de ser pouco ajustado o nome), as suas lendas, os seus mitos, os seus fantasmas, os seus heróis, os seus seja consentida a repetição - paradoxos. Ao abalançar-se à tarefa a que deitava mãos, aproximava-se, porventura sem o suspeitar, dos textos onde cimentara a sua cultura literária: os clássicos. Iria cantar um povo e um território aonde, um dia, chegou um outro povo, vindo de longe e que acabaria por dominá-lo. Como os míticos guerreiros que, capitaneados por Eneias, de Tróia 
vieram até ao Lácio, para fundar uma nova civilização, a romana, mesclada de sangue indígena e sangue forasteiro.

Assim fi era Virgílio, na sua Eneida. Talvez por isso, o canto épico do poeta latino é, ao mesmo tempo, o engrandecimento de um povo e um herói (Eneias, Augusto), o retrato pessimista das atrocidades cometidas nesse percurso de glória e uma reflexão amargurada em torno da condição humana.

Gonçalves Dias, que projectou escrever a "Ilíada brasileira", acabou por seguir de perto as contradiçôes virgilianas. Os seus heróis, entretanto, ao contrário dos de Virgílio, emergem, por assim dizer, do povo conquistado e não do conquistador. E não terão, talvez, na sua génese a configuração de grandeza épica que se exige aos protagonistas de uma epopeia. Mas dão forma a poemas de pendor epopeico, posto que semeados de contradiçóes, como aquele que nos legou o canto das glórias de Roma. É isso mesmo que nos sugere este livro, mormente quando ao capítulo a que dá por título "Virgílio: as contradiçôes de um poeta épico" faz suceder um outro intitulado "Gonçalves Dias: as contradiçóes de um poeta anti-épico".

O melhor emblema, afinal, das contradições do poeta brasileiro é esse misto de herói e anti-herói, o protagonista de I-Juca Pirama, que chora diante da morte iminente, por entender ser mais forte que a coragem guerreira o amor filial, que o fazia sentir precisar dele o pai, na sua velhice (e por isso não morre, pois quem chora não é merecedor de morrer às mãos do inimigo), e regressa, mais tarde, depois de confrontado pelo pai com o seu acto indigno, pronto a enfrentar o destino que, antes, recusara; é ele 'o que há-de ser morto e que é digno de ser morto’, estranhas palavras que dáo o mote a um outro capítulo desta obra.

Foi em meio deste quase labirinto de contradições que decidiu aventurar-se Weberson Grizoste, ao escolher para tema da sua dissertação de Mestrado em Poeta e Hermenêutica $O$ reflexo anti-épico de Virgílio no indianismo de Gonçalves Dias, agora dada a lume com o título $A$ dimensáo anti-épica de Virgílio e o indianismo de Gonçalves Dias. A aventura era quase temerária, pois punha em confronto dois poetas de universos substancialmente distintos e que partiram para as respectivas obras de pontos não menos diferentes. Temerária, também, já que Weberson Grizoste, se conhecia bem a obra do poeta brasileiro e o seu contexto, fica a mais distante, por formação, do convívio com o poeta latino que pretendia ir cotejando. Isso explica, por exemplo, 
aquilo que não faltará quem aponte como fragilidade deste livro: a presença do texto latino surge sempre por interposto tradutor, com todos os riscos que tal opçáo encerra, desde logo na escolha das ediçóes adoptadas, por manifesta incapacidade de compulsar o original. A verdade é que o objectivo do trabalho é Gonçalves Dias e não Virgílio. E esse, Gonçalves Dias, é analisado com fina hermenêutica e aguda capacidade de indagação, sempre em busca, ora de um inventário das contradiçóes gonçalvinas, ora, mesmo, de uma explicaçáo para elas.

Aventura temerária, repito, mas em boa hora iniciada. Talvez náo concluída, convenhamos. Depois da leitura global, aqui efectuada, da obra poética deste notável vulto do Romantismo brasileiro, nos seus poemas mais emblemáticos, nos seus heróis (anti-heróis, afinal, ou mesmo heróis?), faltará um olhar mais atento e demorado sobre os seus textos mais significati os, entre eles aquele que poderia ter vindo a ser o seu poema épico (anti-épico?), Os Timbiras, a tal projectada Ilíada brasileira, de que só terá composto dez cantos, dos dezasseis anunciados, e dos quais a morte prematura e o naufrágio onde ocorreu apenas nos deixaram chegar quatro. Esse, porém, é um desígnio de maior fôlego que, estou certo disso, Weberson Grizoste levará a cabo, com sucesso, nos anos que aí vêm e que já se iniciaram.

Fica-nos, por agora, um retrato lúcido, pertinente, acutilante, da obra do maior indianista da literatura brasileira. $O$ bastante para sobre Gonçalves Dias atrair a nossa redobrada atenção. $\mathrm{O}$ bastante, também, para, em relação a Gonçalves Dias e à sua obra, suscitar um conjunto de perplexidades e refle óes. $\mathrm{O}$ bastante para ser ponto de partida para novas indagaçóes e para a descoberta de novos paradoxos. O bastante para questionar o texto e nos fazer questioná-lo. Essa é também, no fim de contas, uma das funçóes de quem estuda a arte da palavra, a que chamamos Literatura.

Carlos Ascenso André 


\section{Abreviaturas e Siglas}

A canção do tamoio (CT)

A canção do Exílio (CE)

Deprecação (D)

I-Juca Pirama (JP)

Marabá (M)

O canto do guerreiro (CG)

$\mathrm{O}$ canto do índio (CI)

O canto do piaga (CP)

$\mathrm{O}$ gigante de pedra (GP)

Os Timbiras, Introdução, (OT i)

Os Timbiras, Livro I, (OT 1)

Os Timbiras, Livro II, (OT 2)

Os Timbiras, Livro III, (OT 3)

Os Timbiras, Livro IV, (OT 4)

Poema Americano (PA)

Tabira (T)

Visóes (V) 


\section{INTRODUÇÃo}

Canto de celebração, de compleição de heróis, mas onde também encontramos o esmorecimento, a queixa, a decepção, a falha humana. O poema épico gonçalvino acompanha o retrato da sua vida. Recair a escolha no seu indianismo reflecte aquilo que lhe trouxe o sofrimento: a mestiçagem, a impureza racial. Daí o refúgio na raça banalizada pelos interesses da burguesia comercial dos três primeiros séculos da história brasileira, a indígena.

Virgílio celebrou a ilustre e fecunda conquista da pax romana dois milênios antes, imortalizando em verso épico a altivez de Roma, o arquétipo homérico, pleno de vida resplandecente, que representava para ele, como para os poetas que o antecederam e os que se lhe seguiram, um marco dificilmente transponí el ${ }^{1}$.

A presença das obras homéricas na epopeia virgiliana é indiscutível, na opinião generalizada dos estudiosos. Podemos dividir a sua obra em duas partes distintas, correspondendo a primeira às narrativas da Odisseia e a segunda às da Ilíada ${ }^{2}$. Entretanto, Virgílio notabilizou-se não apenas por fazer uso das epopéias homéricas, mas também por se deixar influenciar pelas tragédias jónicas ${ }^{3}$. Para Di Cesare ${ }^{4}$, a glória e a tragédia na Eneida (Enéias) foram notáveis para ambos, e esse é um equilíbrio necessário e arriscado, mas que define a condição humana

Pelo lado épico, Virgílio celebra a glória e a honra dos romanos; mas pelo lado trágico celebra, com lágrimas, os fatigados momentos que os precursores da nação romana se viram obrigados a enfrentar ${ }^{5}$. O modelo antiépico de Virgílio pauta-se por esta premissa: todo o grande personagem virgiliano é uma união de contrários; no caso de Eneias, nota-se claramente que o herói cai primeiro para adquirir grandeza na queda e, seguindo a ideia de Kothe ${ }^{6}$, quanto maior a desgraça que sobrevier, maior será a grandeza. A desgraça de Eneias não é um mero lamento

${ }^{1}$ Carvalho 200813.

${ }^{2}$ V. Pereira 1992 77; Büchner 1963 402; Camps 196926.

${ }^{3}$ Quinn 1968324.

${ }^{4}$ Di Cesare 1974239.

${ }^{5}$ André1992 27. O autor questiona se seria a Eneida um poema de morte ou de vida.

${ }^{6}$ Kothe 198713. 
lacrimoso, mas um duro caminho na aprendizagem da condição humana, transcendendo a doutrinação que lhe é inerente.

A relação intertextual de Virgílio com Homero é aceite em todo universo literário; de facto, é das epopeias gregas que nasce todo o tipo de produçáo literária ${ }^{7}$. Mas na esteira do poeta, outros autores também o fariam, como Dante ${ }^{8}$ e Lucan', que reescreveram Virgílio. A propósito desta questão, conforme veremos neste trabalho, Gonçalves Dias promete criar uma espécie de "genesis americano", denominando-o "Iliada Brasileira", "criação recriada" 10 , mas o que nos deixa realmente é uma "Eneida Brasileira", uma epopeia inacabada. Ou talvez acabada, mas perdida nas profundezas do oceano, quando o poeta náufrago perecera no mar.

O presente trabalho tem como principal objectivo o estudo das marcas fundamentais da Eneida no indianismo de Gonçalves Dias, nas suas linhas de continuidade e intertextualidade que o poeta, embora o desejasse, náo lhe foi possível evitar.

Em momento algum Gonçalves demonstra o seu apreço por uma epopeia de lágrimas e de dores. A sua proposta vai no sentido da criação de uma obra que seja superior a todas, declarando-a como nunca vista. Mas ao incorporar o elemento suprimido e extinto da colonização brasileira, Gonçalves entra em contradição, tornando-se impossível construir uma obra sem lágrimas, sem desespero e sem sofrimentos, porque ao cabo de toda a felicidade aparente está a morte, a única certeza que temos. Isto faz de Gonçalves Dias, na linguagem de Vasconsellos ${ }^{11}$, o poeta brasileiro mais harmonioso e sentimental.

Gonçalves é, em toda a sua história, um homem contraditório. Sofre com os preconceitos, em virtude da sua origem humilde e, ao mesmo tempo, encontra no seu reconhecimento de inferioridade uma maneira de abrandar o seu sofrimento. $O$ poeta que, na opiniāo de Sodré ${ }^{12}$, soube cantar o índio e a natureza, soube também cantar a saudade, o exílio e o mal de amor, com uma força que poucas vezes a língua conheceu tâo grande, e certamente nem uma vez maior. $\mathrm{O}$ poeta transfere para os seus poemas o mesmo sofrimento. As suas personagens também o lamentam quando

\footnotetext{
${ }^{7}$ Jaeger 199564

${ }^{8}$ Martindale 199343.

${ }^{9}$ Martindale 199348.

${ }^{10}$ Moisés 198936.

${ }^{11}$ Vasconsellos 186813.

12 Sodré 1969283.
} 
deveriam demonstrar-se fortes. Exemplo clássico disso é o herói central de I-Juca Pirama.

De acordo com Bornheim ${ }^{13}$, o clássico e o romantismo são duas categorias básicas, elucidativas do desdobramento da cultura. $\mathrm{O}$ romântico seria sempre uma fase de rebelião, de inconformismo aos valores estabelecidos e consequentemente a busca de uma nova escala de valores, através do entusiasmo pelo irracional ou pelo inconsciente, pelo popular ou pelo histórico, ou ainda pelas coincidências dos diversos aspectos. Gonçalves viveu numa época muito próxima da independência brasileira, tendo, aliás, nascido no ano seguinte ao referido evento. A memória viva do colonizador é, sem dúvida, o grande instrumento que move a construção do seu indianismo.

No entanto, o seu indianismo pode ser compreendido como um empenho no sentido de aceitar a dimensão índia da "mestiçagem". Entretanto, a própria necessidade de idealizar a figura indígena, não a assumindo como ela realmente foi - pobre, ignorante, primitiva -, contém em si uma náo explícita confissáo de penúria e vergonha. A dor da perda da identidade original está presente e escamoteada também nas demais imigraçôes, como um filho a falar uma língua que náo se entende, tornando-se um ser estranho, num mundo distante ${ }^{14}$.

Herculano ${ }^{15}$ não teve dúvidas, pois para ele as Poesias Americanas eram exemplos de verdadeira poesia nacional do Brasil; citando O Canto do Guerreiro e Morro do Alecrim, o escritor lamenta aliás o facto de tais poesias não ocuparem a maior parte dos Primeiros Cantos. Para Franchetti ${ }^{16}$, o comentário do prestigiado escritor português valeu, na época, como o baptismo do nascimento da poesia nacional brasileira.

Porém, Gonçalves Dias compóe alguns poemas de tema heróico e outros de tema indígena, embora não lhes tenha conferido forma épica ${ }^{17}$. O seu projecto de compor uma epopeia semelhante às obras homéricas permaneceu inacabado, produzindo apenas um quarto daquilo que havia prometido. Mesmo assim, a sua obra ainda é vista como a mais bela realização do género, na literatura brasileira.

${ }^{13}$ Bornheim 199376.

${ }^{14}$ Kothe, 1997 258-259.

${ }^{15}$ Herculano 1998100 (publicado originalmente na Revista Universal Lisbonense - ano de 184875.

${ }^{16}$ Franchetti 200755.

${ }^{17}$ Franchetti 200755. 
O primitivo americano de Gonçalves Dias é idealizado, é ficção - generosa por certo, mas ficção - para onde confluem os projectos oníricos do poeta, na direcção de uma beatitude utópica e na visualização duma Idade Média miticamente perfeita e feliz ${ }^{18}$. Os seus índios são rudes, severos e sedentos de glória, confiantes na vitória em caso de batalha; para o elemento gonçalvino, a guerra era uma tarefa diária e um motivo de honra maior que um homem poderia encontrar. Para Moisés os guerreiros gonçalvinos são descritos de tal maneira que é "como se a flor da cavalaria arturiana se transplantasse para as selvas tropicais ${ }^{19}$."

A missão de Gonçalves Dias consiste em ultrapassar os termos estabelecidos pela literatura colonial que, desde a carta de Pêro Vaz de Caminha, estabelecera um confronto entre os dois mundos, com a ideia de que o conquistador é o representante da civilização, e os índios os representantes da barbárie; ou de que o primeiro simboliza a bondade natural humana e o segundo corporifica a maldade ${ }^{20}$. Cabia aos conquistadores uma tarefa que o próprio Caminha sugeriu: salvar a terra, salvar a gente que nela habita. Mas por trás desse salvamento e do combate à barbárie praticou-se a barbárie; no combate à injustiça mataram-se homens, velhos, mulheres e crianças; em nome do cristianismo destruiu-se; no combate ao paganismo cometeram-se sacrifícios humanos ${ }^{21}$.

$\mathrm{O}$ facto de Gonçalves utilizar o termo índios revela o desconhecimento da identidade do outro ${ }^{22}$, porque este termo provém do pseudo-hindu; acaba por sua vez o nativo assumindo aquela que lhe foi atribuída ${ }^{23}$. Herculano também reconheceria que o poeta tem muito de trato português na sua lírica. Mas o indianismo gonçalvino possui três grandes autenticidades: pelo

${ }^{18}$ Moisés 198936.

${ }^{19}$ Moisés 198936.

${ }^{20}$ Kothe 1997237.

${ }^{21}$ Kothe 1997245.

${ }^{22}$ Para Gonçalves, o índio é um estrangeiro. O facto de habitarem nas mesmas terras e possuírem descendência em comum não evitou que o tratamento dispensado possuisse um determinado carácter de "estrangeiredade". Para esta realidade apontam claramente os estudos de Ricoeur, Life in quest of narrative e Sobre a tradução. Através do esclarecimento da hospitalidade linguística e do fenómeno em que a intraduzibilidade se torna ultrapassável, podemos perceber como se dá o reconhecimento da identidade do outro, e daí percebermos o papel desempenhado por Gonçalves Dias na constituição do seu indianismo. Por exemplo, a admiração pelo estrangeiro de que fala Ricoeur, num primeiro passo, ganha respaldo dentro da poética gonçalvina.

${ }^{23}$ Kothe 1997236. 
sangue, porque era filho de uma guajajara ${ }^{24}$ com um português; pelo conhecimento directo com os índios; e em terceiro lugar, pelos estudos acerca do Brasil e da Oceânia ${ }^{25}$.

Salvo o terceiro aspecto enunciado, os dois primeiros são controversos: o primeiro porque carece de maiores fontes, náo se sabendo ao certo se o poeta teria sangue indígena na sua miscigenação, facto que muitos escritores não reconhecem e não é já possível comprovar (nem através de análise por parentes, porque náo existem descendentes do poeta - que náo chegou a conhecer o local da sepultura da sua filha - nem através da arcada dentária, visto que o seu corpo desapareceu no mar); o segundo porque, conforme veremos, o poeta atribui aos Timbiras costumes dos tupinambás, embora alguns teóricos afirmem que tal facto se deva ao conhecimento que o poeta tinha dos tupinambás e, ao mesmo tempo, à sua ignorância relativamente aos costumes dos Timbiras.

Todavia, optamos por acreditar que o poeta teria optado pelos Timbiras, índios que ocupavam a maior parte do seu estado natal (o Maranháo), atribuindo-lhes costumes tupinambás, talvez porque estes já eram tidos como uma raça nobre; talvez pelo pouco conhecimento da tribo Timbira, o poeta quisesse legitimá-la. De acordo com Angione Costa ${ }^{26}$, os Gês:

Não foram povos de civilização inferior aos Tupis-guaranis, antes tão adiantados quanto eles, se não mais nas indústrias domésticas, tendo, porém, ânimos menos propensos às atraçôes da guerra, aos pendores marciais. Só assim se explica que, em todos os campos onde se defrontaram com os seus valentes e aguerridos inimigos, sempre lhes cederam o lugar, sempre se deixaram bater.

No entanto, esta afirmação não compromete a obra de Gonçalves, porque o seu carácter não é histórico e sim poético. Em diversos momentos, a verdade poética seria inquestionável na obra do poeta. Gonçalves sobrepóe à realidade, arquitecta uma sociedade convencional, uma civilização ideal, um Brasil fora da sua rude verdade ${ }^{27}$.

${ }^{24}$ A origem de Gonçalves é contestada. Sabe-se que o poeta era mestiço disso não há dúvidas; no entanto não se tem conhecimento algum se o poeta teria sangue indígena. Os Guajajaras são um grupo indígena da família Tupiguarani, o que coloca em dúvida a afirmação de Coutinho e Rica do.

${ }^{25}$ Coutinho 1986 75; Ricardo 196426.

${ }^{26}$ Costa 1934190.

27 Sodré 1969273. 
Através desta recriação literária, veremos na poesia gonçalvina as suas duas grandes linhas de orientação, épica e antiépica, os refle os antiépicos virgilianos na sua obra, bem como o seu contragosto e a falha na criação de um conjunto de obras antiépicas, porque, no fundo, este nunca teria sido o seu objectivo final, o que consideramos pa te da contradição de sua dialéctica. 
Capítul o I

Epopéia e anti-epop éia: a intençã o e o r esul tado 
O que permanece é a obra dos poetas.

Hölderlin

Há mais de dois mil anos que Virgílio celebrou, numa epopeia, a construção da pax Romana; o poeta deixava proclamada a sua escolha - a vida. Porém, muitos foram os que não a apreenderam, entre eles o seu próprio herói ${ }^{1}$. Há uma presença clara da influência homérica na poesia de Virgílio, mas entre eles existe um mundo a separá-los. Mais do que o fulgor dos dias heróicos de Micenas e de Tróia reflectida na Ilíada e na Odisseia, Virgílio sentiu as sombras que invadiram os seus heróis e, no fundo, a grande e desventurada família humana. Além do arquétipo de heroísmo, na sua tradicional versão guerreira e inventiva, Virgílio estava preocupado em desvendar a acepção da acção humana e o estabelecimento de procedimentos modelares. A partir dessa premissa, presumimos por que razão Virgílio não pode conceder a Eneias uma imagem resplandecente.

A epopeia é apresentada como um espaço de luz, ao passo que a antiepopeia possui a sua superfície envolta na penumbra ${ }^{2}$. $\mathrm{Na}$ epopeia manifesta-se a peculiaridade da educação jónica; em compensaçáo, deparamo-nos com outros povos, nos mesmos estágios de desenvolvimento, e com uma organização social distinta, com cantos heróicos análogos àqueles dos gregos primitivos ${ }^{3}$. Mas é do modelo grego que surge toda a literatura ocidental posterior.

O mundo dos heróis, dos deuses e dos homens é um cosmos, um todo vivo no qual todo o movimento gira em torno da justiça, da ordem e do destino. O nascimento e a morte são os extremos que circundam este universo $\mathrm{o}^{4}$. Neste extremo surge o homem. A "hybris é o pecado por excelência contra a saúde política e cósmica 5." A cólera de Aquiles, o orgulho de Agamémnon, a

${ }^{1}$ Carvalho 200864.

${ }^{2}$ De acordo com André 1993. Através do contraste luz/penumbra, o autor discorre sobre as contradiçôes gerais da literatura humanista da época das descobertas. "Poema de morte? Ou de esperança e de vida?" André 199227.

${ }^{3}$ Jaeger 199564.

${ }^{4} \mathrm{Paz} 1982244$.

${ }^{5}$ Paz 1982 244-245. 
inveja de Ájax, a presunção de Odisseu, são exemplos de heróis que cometem a hybris. No caso de Aquiles, Adorno e Horkheimer afirmam que a cólera do filho da deusa contra o rei guerreiro e organizador racional demonstra a inactividade indisciplinada desse herói ${ }^{6}$. Já Odisseu manipula os processos de assimilação ao estado natural como um meio de dominar a natureza, ao se denominar Oudeis. Junto da hybris, está o seu poder destruidor. A ira desmedida de Aquiles culmina no sofrimento mais profundo: a morte daquele que lhe é mais caro, o amigo Pátroclo. Desse sofrimento nasce o desejo de vingança ${ }^{7}$. Mas o desejo de vingança é necessário, para que a Legalidade Cósmica seja restaurada. Através da justiça, a ordem e o destino são resgatados, e o equilíbrio cósmico é restabelecido ${ }^{8}$.

Mas não é apenas esta a configuração de um poema épico, para Bowra:

An epic poem is by common consent a narrative of some length and deals with events which have certain grandeur and importance and come from a life of action, especially of violent action such as war?.

Quanto à sua forma no conceito grego, um poema épico deve ser escrito em hexâmetros dactílicos. Deve ser um poema longo, dividido em vários livros, e deverá contar uma história.

Os primeiros poetas romanos, no entanto, não obedeceram a estas exigências. Virgílio, pelo contrário, torna-se servo desse modelo, pelo que alguns críticos questionam as limitaçóes da história e da técnica. A diferença que temos entre Virgílio e Homero é que, no caso deste, se trata de uma epopeia oral, enquanto para o poeta romano é totalmente literária ${ }^{10}$. Para Quinn ${ }^{11}$, Virgílio é a evocação mais profunda de Homero. Mas isto não indica que haja divergências entre estes poetas épicos. Parry ${ }^{12}$ observa a duplicidade da Eneida; este autor descreve as características utilizadas por Virgílio, que permitem catalogar a sua obra como uma epopeia que ao mesmo tempo se torna uma antiepopeia.

\footnotetext{
${ }^{6}$ Adorno e Horkheimer 198555.

${ }^{7}$ Lesky 199625.

${ }^{8} \mathrm{Paz} 1982243$.

${ }^{9}$ Bowra 196653.

${ }^{10}$ Quinn 1968277.

${ }^{11}$ Quinn, 1968278.

12 Parry 1966 107-123.
} 
Quando Umbro aparece diante do povo de Marrubia, ele é o mais valente. Ele é um sacerdote, possui a arte do sono e do controlo sobre as mais ferozes serpentes. Aqui se trava o caminho homérico e tem início o Virgílio antiépico: as ervas e o encantamento do sacerdote náo o salva e ele é ferido pela lança dos Dárdanos. O poeta encerra então a cena com uma lamentação esplêndida.

Te nemus Angitiae, vitrea te Fucinus unda, Te liquidi flevere lacus. (Eneida 7.759-760)

Numa análise quase microscópica, Parry observa a presença do trícolon, três sucessivos substantivos-frase. Aqui encontramos um assíndeto sem os conectores gramaticais que, juntamente com o verbo fleuere, é um dispositivo que combina com uma apóstrofe. O guerreiro inoperante é endereçado directamente na segunda pessoa. O primeiro é nemus Angitiae, o segundo é o nome próximo do lago Fucinus e o terceiro é o lago. Os três nomes são diferentes no seu conjunto. $\mathrm{O}$ primeiro e o segundo opóem-se ao terceiro por serem nomes dos lugares; o segundo e o terceiro opóem-se ao primeiro por possuírem adjectivos, encontrando-se os adjectivos separados dos substantivos; o primeiro e o terceiro opóem-se ao segundo por causa das variaçóes de anáforas: te personifica a rectidão do lamento ${ }^{13}$. O trícolon com a anáfora é um dispositivo formal forte que se apropria dos sons do lamento público ${ }^{14}$. Parry observa que o trícolon fora utilizado por Homero, o que confirma que Virgílio se inspirara no autor grego. O exemplo utilizado por Parry está no final do segundo liv o de Ilíada:

The forces from Mysia were led by Chromius and by Ennomus, a diviner of birds. But his birds did not keep him from black death. He was to be slain by hands of swift Achilles at the river, where many another Trojan fell ${ }^{15}$.

Concernente à característica homérica presente na obra de Virgílio, Parry observa que Virgílio tem pelo menos duas passagens homéricas em mente, uma do vigésimo terceiro livro de Ilíada, onde Aquiles tenta abraçar o espectro de Pátroclo, e outra

\footnotetext{
${ }^{13}$ Parry 198758.

${ }^{14}$ Parry 198759.

${ }^{15}$ Parry 198759.
} 
do décimo primeiro livro de Odisseia, onde Odisseu tenta abraçar o espectro de sua mãe. No final do segundo livro de Eneida, Eneias tenta abraçar o espectro de sua esposa, mas em vão. Isto indica que Eneias é similar aos heróis homéricos, mas este facto é isolado, já que Virgílio possui uma característica que os torna diferentes. No poema de Virgílio, a sua central característica é a tristeza, a perda, a frustração, o sentido do insubstanciável que poderia ser palpável e satisfeito ${ }^{16}$. A imagem que Virgílio nos dá das almas no além é a da inanidade e da inconsistência, pois tudo é simulacro, imagens e sombras ${ }^{17}$.

Os heróis homéricos possuem uma característica que, por sinal, está além da nossa existência física: embora Aquiles se precipite pelas próprias mãos e Odisseu sinta este tipo de frustração, os heróis homéricos amam e apreciam a vida ${ }^{18}$, enquanto Eneias lamenta o facto de não ter sucumbido com os troianos que pereceram diante da muralha de Tróia.

De acordo com Quinn ${ }^{19}$, o desejo de matar é um sentimento natural e um tanto necessário no herói. Mas, quando se torna uma vitória forçada, para nós ela pode adquirir uma imagem desagradável, de maneira que nos leva, por vezes, a ver a morte apressada como uma forma de expiação. Para Farron ${ }^{20}$, o combate entre Eneias e Turno está modelado a partir do combate entre Aquiles e Heitor. $\mathrm{O}$ combate homérico é a última luta na epopeia, assim como o combate virgiliano. Mas, após o combate de Aquiles e Heitor, seguem-se as lamentaçóes dos penates vencidos, o funeral de Pátroclo, a visita de Príamo a Aquiles e, finalmente, o funeral de Heitor, enquanto Virgílio encerra a sua obra com a morte violenta de Turno, sendo este o último episódio. Farron ${ }^{21}$ também observa que, apesar do elevado grau de violência nas tragédias gregas, apenas quatro terminam violentamente (Prometeu Agrilhoado de Esquilo, Electra de Sófocles e, de Eurípides, as obras Hécuba e Héracles) e nenhuma delas termina de forma tão penosa como a Eneida.

Enquanto a Ilíada celebra a guerra de Tróia, o poema virgiliano comemora a grande vitória, a batalha de Actium, que

\footnotetext{
${ }^{16}$ Parry 196662.

17 V. Pereira 1992106.

${ }^{18}$ Parry 196663.

${ }^{19}$ Quinn 196816.

${ }^{20}$ Farron 1982136.

${ }^{21}$ Farron 1982138.
} 
simboliza o triunfo sobre os anos de sangue da guerra civil ${ }^{22}$. Mas a analogia virgiliana distancia a sua obra do texto homérico, porque

Homer's tale is ingenuous fiction intended for an audience half disposed to believe. Virgil makes belief in his stylized fantasy impossible by interspersing among the parts we might be prepared to believe passages so patently ironical in intent (for example, Charon) or allegorical (for example, the vestibule of the underworld) that the question of belief hardly arises. ${ }^{23}$

Já havia dito Auerbach ${ }^{24}$ que Homero era um mentiroso inofensivo, quando fazia uma alusão a respeito da diferença entre o autor bíblico e o grego. Homero mentia para agradar, era consciente das suas metas e mentia em nome de uma pretensa autoridade absoluta. Para Quinn ${ }^{25}$, Virgílio é espiritualmente superior a Homero, mas isto náo garante que seja superior artisticamente, porque a arte poética é um produto meramente cultural ou individual.

Enfim, o objectivo de Virgílio era a criação de um poema de vida, mas viu a sua obra migrar de um espaço de luz para um espaço de sombras; o próprio poeta é afectado por esta mutação: no leito de morte, quis destruir seu poema - testemunho amargurado de uma época conturbada. A antiepopeia submerge aquilo que é o componente constitutivo fundamental da sua correspondente contrária - a distância épica - ao suprimir o espaço temporal entre o universo constituinte e a época do seu autor e de seus contemporâneos. Para Carvalho ${ }^{26}$, o universo épico é por natureza um mundo ideal. A antiepopeia, por sua vez, transforma este mundo perfeito do passado - ao dar lugar às deficiências do tempo presente e real, com o seu cortejo de infortúnios, misérias, comiseraçóes, baixezas. Asseverada a incoerência de enaltecer a contemporaneidade, a grandeza volve-se em pequenez, a consagração heróica em desabafo, em crítica e em denúncia. A chama de outras épocas abranda-se e, não raro, fenece.

\footnotetext{
${ }^{22}$ Quinn 196822.

${ }^{23}$ Quinn 1968287.

${ }^{24}$ Auerbach 198611

${ }^{25}$ Quinn 1968288.

${ }^{26}$ Carvalho 200836.
} 
Capítul o II

Vir gílio: as c ontradiç óes de um poet a épico 
Les plus déséspérés sont les chants les plus beaux, Et j'en sais d'immortels qui sont de purs sanglots.

"Nuit de Mai" - Musset

Em Homero, na Ilíada, Eneias salva-se da morte através de uma intervenção divina: não resta nenhuma dúvida de que, na tradição, era favorecido pelos deuses e o seu destino era sobreviver à guerra. A Eneida é a história da migração dos remanescentes troianos que, sob o comando de Eneias, deixaram as muralhas destruídas de Tróia e avançaram rumo a Itália. Virgílio adopta a forma de Homero, mas não adopta a mesma atitude 2 . Em Homero, os deuses e as deusas são tratados com limitaçôes quando, na realidade, eles deveriam ser sobrenaturais, pois intervêm na vida dos humanos, sendo a sua intervenção mais física do que divina ou mágica. Os heróis gregos possuem características sobre-humanas e, normalmente, ascendência divina, seja de um deus ou deusa ${ }^{3}$, ao passo que os heróis virgilianos assumem uma categoria mais humana que divina, embora não abandonem a ascendência divina prefigurada nos he óis homéricos.

Para Putnam ${ }^{4}$, na última parte da Eneida, Eneias torna-se uma imagem de Aquiles . Putnam $^{6}$ ressalta que Turno ${ }^{7}$ e Heitor são derrotados sozinhos. Eis a grande diferença entre os heróis vencidos: Heitor e Turno fazem as suas súplicas. Turno pela vida, Heitor por um enterro aceitável. "Hector attempts to supplicate Achilles only after he has been mortally wounded; it is not, then, life that he asks for but only a decent burial"." Mas isto não indica que Virgílio tenha falhado no seu objectivo de construir uma narrativa épica. Para Perret, o optimismo na Eneida é incontestável.Virgílio admirava Augusto. Via na sua obra a realizaçáo das melhores partes da vida romana. Acreditava que

${ }^{1}$ Camps 196911.

${ }^{2}$ Quinn 1968284.

${ }^{3}$ Quinn 1968285.

${ }^{4}$ Putnam 1988196.

${ }^{5}$ Johnson 1976116.

${ }^{6}$ Putnam 1988199.

${ }^{7}$ Turno é anti-Eneias e o Aquiles do Lácio, que luta pela destruição dos troianos. André1992 43.

${ }^{8}$ Johnson 1976115. 
Roma trazia à humanidade uma salvação definiti a, escrevendo a Eneida com intenção de o dizer e aom mesmo tempo partilhar

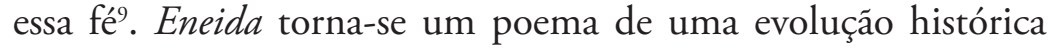
que tem êxito - o herói desabrocha guiado por um deus - dado que ao herói, o poeta une um valor moral. Se lhes atribuímos um significado universal, logo somos tentados a atribuir a Virgílio um optimismo de princípio, universal também ${ }^{10}$.

Não sendo incontestável, Perret então afirma: "Virgile, comme les philosophes, est optimiste quand il pense à l'ordre du monde; il est alors tout admiration et enthousiasme ${ }^{11}$." Virgílio torna-se optimista ao pensar a ordem do mundo. Mas este optimismo pode ser visto à maneira de Camps ${ }^{12}$, ou seja: Virgílio, ao compor o poema, não quis rivalizar com Homero, porque a sua obra é uma continuação de grande envergadura, onde os troianos abrem à maneira do sucesso dos gregos.

Todavia o pessimismo está presente na obra de Virgílio, impregnado por toda parte: quando o poeta evoca o horror a respeito do duelo de César e Pompeu; ou os campos fúnebres de Filipos; e, talvez o episódio mais importante, quando alude vagamente às atrocidades cometidas durante o período de confusão da guerra da Perúsia ${ }^{13}$ (Setembro 41 a.C. - Julho 40 a.C.). Para Brisson ${ }^{14}$ e $\mathrm{Jal}^{15}$, o pessimismo virgiliano é uma particularidade resultante desta guerra civil.

Para Parry ${ }^{16}$, Dido e Cleópatra eram inimigas de Roma, e por isso é que ambas sucumbem à morte. "Dido-Cleopatra is the sworn enemy of Rome." Logo são culpadas. Se não fossem culpadas, o destino não as destruiria. Porém, essa culpa não as diminui, antes as engrandece. Como no caso de Prometeu, Antígona e Édipo: o ser cumpre-se e não regressa ao $\operatorname{caos}^{17}$.

Que Virgílio sofreu influência homérica, disso sabemos. Quinn $^{18}$, no entanto, frisa uma cena de suma importância no tocante ao serviço da influência homérica em relação aos termos

\footnotetext{
${ }^{9}$ Perret 1967343.

${ }^{10}$ Perret 1967 343; Wilsen 1973737.

${ }^{11}$ Perret 1967356.

${ }^{12}$ Camps 196920.

13 Perret 1967360.

${ }^{14}$ Brisson 1966266.

15 Jal 1963231.

${ }^{16}$ Parry 196670.

${ }^{17}$ Paz 1982248.

${ }^{18}$ Quinn 1968 8. Ver Ilíada 22.71-76.
} 
antiepopeicos: Príamo torna-se uma figura patética e exemplo da desonra que é matar um homem idoso em batalha; não seria desajustado afirmar que, a partir dessa imagem, Virgílio teria decidido a morte vergonhosa de Turno.

Virgílio reúne em sua obra o conjunto das obras de Homero ${ }^{19}$, "meio odisseica, meio ilidíaca» ${ }^{20}$. A imitação homérica, porém, não compromete a originalidade do poema, porque o herói virgiliano apresenta as suas próprias características" "Homer was for Virgil the archetypal poet, the grand original ${ }^{22}$." Mas a Eneida não sofre influência apenas de Homero; denotam-se inúmeros resquícios de tragédias, sobretudo de tragédias gregas ${ }^{23}$. A história da guerra e das armas descrita na Ilíada e a história de aventuras de um homem escrita na Odisseia, são influências distintas que encontramos logo nas primeiras linhas de Eneida ${ }^{24}$.

\section{Ille ego qui quondam gracili modulatus avena \\ Carmen, et, egressus silvis, vicina coegi \\ Ut quamvis avido parerent arva colono, \\ Gratum opus agricolis; at nunc horrentia Martis \\ Arma virumque cano Trojae qui primus ab oris \\ Italiam, fato profugus, Lavinaque venit \\ Littora: (Eneida 1.1-7)}

Otis elabora um esquema sobre a imitatio virgiliana: de acordo com este autor, a influência dos seis primeiros livros da Eneida pertence à Odisseia; consequentemente, os seis últimos à Ilíada. Porém o sétimo livro da Eneida possui uma recapitulação daquilo que ocorreu no primeiro livro, por conseguinte é a abertura da segunda parte que compóe a epopeia ${ }^{25}$.

Virgílio inverte a sequência de Homero, - Ilíada e Odisseia ${ }^{26}$ - a primeira narra a guerra de Tróia, enquanto a segunda narra o retorno dos Heróis, personificando-os em Odisseu. Partindo do mesmo horizonte, Virgílio, em primeiro lugar, descreve Eneias

19 Büchner 1963 402: relativamente à narrativa semelhante a Odisseia; Camps 1969 26: no que concerne à narrativa correspondente a Ilíada. Otis 196442.

${ }^{20}$ V. Pereira 1992 77; Williams 198383.

${ }^{21}$ Brisson 1966257.

${ }^{22}$ Clausen 196675.

${ }^{23}$ Maguiness 1963478.

${ }^{24}$ Quinn 196841.

25 Otis 196491.

${ }^{26}$ Para Jaeger 1995 37: a Odisseia é uma continuação da Ilíada. 
deambulando à procura da nova pátria, para posteriormente narrar a guerra de conquista do Lácio ${ }^{27}$. Logo, a guerra pela conquista da terra prometida está na última parte da Eneida ${ }^{28}$. Para Jaeger, a Ilíada é provavelmente anterior à Odisseia. A primeira baseia-se no pathos, em que o destino dos guerreiros é o ideal; já a segunda baseia-se no Ethos, que trata da cultura e da moral aristocrática $^{29}$. A diferença que temos entre as duas composiçóes épicas não é apenas no conceito da própria linearidade histórica da guerra, mas no facto de a Ilíada se basear numa alocução em que o destino das naçóes é resolvido na batalha, ao passo que a Odisseia atinge um momento histórico mais elevado, em que o discurso democrático é o facto essencial para que os povos atinjam os seus objectivos. Alcínoo, por exemplo é a pintura fiel de um governante das cidades-estado da Grécia Antiga.

No entanto, há uma coisa fundamental em Virgílio: a estrutura da epopeia. $\mathrm{O}$ autor organiza conscientemente o conflito ou tensão. A própria história de Virgílio nos direcciona para Homero, porque, de certa forma, aquela é continuação desta ${ }^{30}$. Os heróis viajando pelo mar, as mesmas estruturas divinas, os concílios idênticos entre deuses, com deuses oponentes e com a ajuda divina da autoridade maior, Zeus/Júpiter. Com a excepção clara de que na Eneida não há nostos, apenas nostalgia ${ }^{31}$. Obviamente que Virgílio não pretendia glorificar Eneias. Ao nível do paradoxo, ele usa o modelo de luta da Ilíada. Porém, de acordo com Otis ${ }^{32}$, Virgílio realmente desejou representar Eneias como um herói romano, talvez como um Augusto que empreende a guerra no interesse da paz, e em ordem a uma mais elevada civilizaçáo.

No entanto há uma grande similaridade entre a composição de Virgílio e a de Homero ${ }^{33}$ : entre eles usaremos o exemplo de Pöschl citado por Büchner no tratamento de Virgílio em relação à Odisseia:

${ }^{27}$ Büchner 1968519.

${ }^{28}$ Camps 196913.

${ }^{29}$ Jaeger 199566.

${ }^{30}$ Quinn 1968289.

${ }^{31}$ Medeiros 199212.

32 Otis 1964 in A study in civilized poetry.

${ }_{33}$ Entre estas similaridades destacamos que "Aeneid I-VI repeats the main plot of Odyssey V-XII". Otis 1964 30. Todavia o livro V de Eneida está baseado na Ilíada, nos cantos XV e XXIII. Otis 1964 32; Büchner 1963 393. Os jogos fúnebres são obviamente modelados no episódio de Pátroclo no canto XXIII de Ilíada, ao passo que o ato de pôr fogo nos navios, no curso contado na Ilíada XV. Otis 1964 38. Do canto VII-XII o herói é emprestado da Ilíada. Otis 196463. 
L'introduzione con la catastrofe provocata dalla divinatà nemica, la catastrofe per se stessa, il monologo disperato dell'eroe, il porto di Forci, il discorso consolatore, l'incontro con Venere come trasformazione dell'incontro di Ulisse con Atena ad Itaca, l'invisibilità dell'eroe durante il suo cammino attraverso Cartagine come imitazione dell'arrivo di Ulisse nella città dei Feaci, l'incontro con Didone con il confronto di Nausicaa, l'apparizione di Ênea davanti a Didone sotto le sembianze di uno straniero, cui la protettrice dà una bellezza raggiante, il discorso fra Giove e Venere, come imitazione del dialogo fra Zeus ed Atena nel primo libro dell'Odissea, addirittura il motivo intimo del discorso di Giove, e, cioè, l'interpretazione del poema ${ }^{34}$.

Ao apoderar-se da forma homérica, Virgílio cria uma série de convençóes que o dificultam na técnica; de acordo com Quinn, o primeiro problema é o dos deuses e o segundo é o da motivação ${ }^{35}$. Nestas obras, os eventos são causados pelos deuses. Há uma semelhança muito grande entre o mundo cósmico de Virgílio e o de Homero $^{36}$, porque em ambas as obras o destino dos homens está ligado aos interesses dos deuses. Mas, no caso de Virgílio, há uma determinada distância entre a humanidade e o $\operatorname{cosmos}^{37}$, ao contrário, como já dissemos, dos heróis homéricos, que eram super-homens e super-mulheres. No mundo épico romano, toda a acção humana é dominada por uma estrutura cósmica semelhante à de Homero, mas, ao contrário dos heróis deste, o herói virgiliano torna-se $\mathrm{uma}^{38}$ "simples ferramenta nas mãos de um deus." Para Quinn ${ }^{39}$, no entanto, esta é a impressão que Virgílio quis causar, porque "the exploitation of the technique, like the exploitation of form, depends on an illusion of strict adherence."

O segundo requisito da técnica era a motivação, porque o público de Virgílio era diferente do público de Homero, e, por isso, Virgílio explora temas de interesse romano. Os romanos tinham um especial apreço pela moral, pela rotina, e um interesse

${ }^{34}$ Büchner 1963 520-521.

35 Quinn 1968300.

${ }^{36}$ Camps 196915.

${ }^{37}$ Otis 1964 49: "Homer's gods are not so divided (Zeus is more powerful and more omniscient than the other gods but there is no definiti e and consistent system of subordination)".

${ }^{38}$ Paz 1982241.

${ }^{39}$ Quinn 1968303. 
dominante pela história ${ }^{40}$. Virgílio apossa-se destes factores para produzir a sua epopeia. Mas, ao contrário de Homero, Virgílio reúne epopeia e tragédia ${ }^{41}$, e com isto, consegue provocar o sentimento de frustração no leitor:

As figuras virgilianas parecem mover-se num terreno fluido, misto de consciência e inconsciência, de verdade e falsidade, num universo de personagens desfocadas, de fragmentos caleidoscópicos, de inconsistências. Assim abre caminho à inquietude; daqui à frustraçáo, um passo apenas ${ }^{42}$.

O quinto livro da Eneida - que narra a viagem inesperada para a Sicília, a morte de Palinuro e os jogos fúnebres em honra de Anquises - decorre num ambiente de alegria desportiva e contrasta com a tentativa de incêndio dos navios pelas mulheres troianas. Sobre o contraste, V. S. Pereira ${ }^{43}$ afirma que "Virgílio habituou-nos a este constante desandar da roda da fortuna." Perante o incêndio, apesar de terem sido contidas as chamas, Eneias mergulha na depressão e questiona o próprio prosseguimento da viagem. Neste ponto, Eneias rasga as vestes e pede a Júpiter que lhe acuda ou o fulmine pelas suas próprias mãos ${ }^{44}$.

Enquanto, no primeiro livro, o herói tinha encorajado os seus camaradas a prosseguir, agora, nesta circunstância, é Nautes, com uma tímida ajuda de Palas, quem o incita a enfrentar a situaçáo ${ }^{45}$. Eneias retorna constantemente ao passado, parece hesitar naquilo que tem de fazer. Porém, o herói não é um cobarde, apesar de noutra ocasião evocar a morte. Mesmo após receber uma ordem divina para edificar uma nova Tróia além do mar, o herói não obedece, nem mesmo quando o sacerdote Panto anuncia o fim de Tróia e de seus habitantes; nesta ocasião Eneias reúne um grupo de desesperados e juntos bradam ${ }^{46}$ : Moriamur, et in media arma ruamus. IUna salus victis, nullam sperare salutem. (Eneida 2.353-354)

Portanto, Eneias torna-se um herói com as mesmas configuraçôe gregas, mas com características distintas. Eneias é - ninguém o

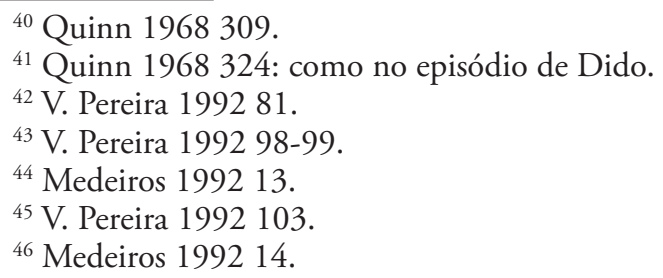


duvida - uma prefiguração de Augusto ${ }^{47}$. Deve considerar-se que as diferenças entre Eneias e os heróis homéricos também são culturais e históricas ${ }^{48}$. Então Medeiros deixa uma pergunta: "Quem é Eneias?" $\mathrm{Na}$ intenção geral do poema é Augusto, reafirma ainda que também é António em Cartago; Heitor vitorioso de AquilesTurno, no Lácio. Mas logo faz uma pergunta: "E a outra face? ${ }^{29}$." E afirma: "Eneias é, de algum modo, o próprio Virgílio ${ }^{50}$, um Virgílio que, segundo o mesmo autor, corresponde à representação do mosaico de Hadrumeto, um Virgílio cujas faces cavadas, cujos olhos cheios de uma chama sombria, e cuja fronte virada para um futuro incógnito e distante, revelam um homem do passado, um homem de lágrimas, cheio de incertezas, de angústias e de frustrações, cuja vitória é igual à derrota. Prova disso é que Virgílio tentou destruir o seu poema antes da morte e morreu profundamente infeliz, mas não desesperado: "Virgílio acreditava que mais longe, para além do éter, mais tarde, para além do tempo, o sangue e as lágrimas do infeliz haviam de florir em sóis ${ }^{51}$." Para Medeiros, a outra face é Eneias, porque, ao pensar no rosto do herói, não o consegue fazer pensando na luz hierática e no queixo voluntarioso de Augusto, mas sim de acordo com a representação de Virgílio no mosaico de Hadrumeto. Virgílio, apesar de se sentir atraído pelo projeto da pax Romana, discordava do rumo que os acontecimentos, na sua particularidade, iam tomando. Era-lhe impossível, por isso, dar a Eneias e à sua missão uma imagem única e imaculada. Não o fez ao longo do poema e, no final, a vitória de Eneias tem o amargor da derrota. Assim, o contraponto inflexí el da ambiguidade e da frustração parece ter-se acentuado no final da Eneida. E é irretorquível que indignata e umbras são discordantes no termo de um poema épico ${ }^{52}$.

Em Cartago, Eneias chora diante das pinturas de um templo cuja evocação rememorava a guerra de Tróia. Chora

${ }^{47}$ Büchner 1963 526, afirma Augusto e acrescenta os romanos pertencentes à gens Iulia. Brisson 1966251 "grâce à son adoption par Cesar, Octave appartenait à la gens Julia, c'est-à-dire à une vieille famille patricienne qui se réclamait précisément d'Enée comme ancêtre." Otis 1964 96: The pius Aeneas is thus the ideal man or hero of Virgili's Augustan ideology. Haecher, 1966, 68. "And this of Aeneas, of the ancestor of Caesar, of the mirror of Augustus! Aeneas was no victorious Greek, but a defeated Trojan like Hector".

${ }^{48}$ Quinn 196852.

${ }^{49}$ Medeiros 199221.

${ }^{50}$ Medeiros 199222.

${ }^{51}$ Medeiros 199222.

${ }^{52}$ V. Pereira 1992130. 
como Odisseu chorou diante do canto de Demódoco, na terra do rei Alcínoo. Odisseu, porém, era um vencedor e Eneias um derrotado. Odisseu retornava à pátria e Eneias não tinha mais uma pátria. As elocuçôes trazidas por estas pinturas estavam repletas de nostalgia daquilo que se não devia mais cantar. Não havia nostos (retorno), mas apenas nostalgia. O choro de Eneias é sobre si mesmo, sobre o seu infortúnio, sobre a desventura dos seus camaradas. De acordo com Medeiros"53, "Eneias é o único herói épico que, na sua primeira apresentação, nos aparece a desejar a morte." Uma similaridade que encontramos com o livro de Job, texto igualmente épico, onde o patriarca amaldiçoa o dia do seu próprio nascimento. Todavia, neste texto épico, o patriarca não deseja a morte mas espera por um auxílio divino ${ }^{54}$.

Eneias parece ser dos únicos heróis cuja desgraça é total: derrotado na guerra, perde a família, a pátria, presencia a morte do rei Príamo e de toda família real, além de muitos camaradas. Peregrino pelo mundo, parte para conquistar uma terra, ciente da desgraça que lhe resta. A esperança no futuro não lhe parece compensar a perda do passado. Esta é uma similaridade com o patriarca Job, que não tem outra esperança a não ser o auxílio divino, porque a sua ruína é total. Eneias também não tem escolha, nem mesmo quando deixa Cartago. Mas Eneias tem perdas sucessivas e paulatinas, ao passo que a ruína de Job é repentina. Dentro de instantes, náo lhe resta nada a não ser os lamentos e os monólogos. No caso de Eneias, ele perde Dido, mas antes já tinha perdido a esposa e o pai, quando a ambos desejaria afirmar o seu amor. "É difícil conceber frustração maior para um eleito. Um eleito que dir-se-ia condenado à insatisfação e ao espectáculo da morte 5 ."

Há ainda uma grande similaridade entre Eneias e uma personagem do livro do Gênesis. Eneias é semelhante a Abraão ${ }^{56}$ pois, nesta estranha analogia, ambos recebem uma promessa de grande futuro para sua posteridade, mas no decorrer desta conquista, estes heróis têm de abandonar o passado ${ }^{57}$. $\operatorname{Lot}^{58}$ é semelhante a Anquises, porque ambos saem na companhia dos heróis, mas devem ficar pelo caminho. Lot tem maior sorte que

${ }^{53}$ Medeiros 199212.

${ }^{54}$ Job 13.15. "Mesmo que me tire à vida, não tenho outra esperança"

${ }^{55}$ Medeiros 199217.

${ }^{56}$ Camps 196922.

${ }^{57}$ Génesis 13.1-13.

${ }^{58}$ Haecher, 1966, 70. O autor compara o exemplo de Lot. 
Anquises, porque enquanto o primeiro partiu para uma terra alheia, o segundo sucumbe à morte. Agar e Ismael são semelhantes a Dido e Turno; no caso de Agar e Dido, a primeira torna-se concubina de Abraão e a segunda torna-se mulher de Eneias, mas ambas devem ser abandonadas. Agar parte para o deserto, enquanto Dido morre e vai para o mundo dos mortos (ambos os lugares representam o caos). Já Ismael vê-se desprovido da paternidade. $\mathrm{O}$ abandono de Ismael pode ser comparado à morte violenta de Turno, porque assim como um acto bárbaro de abandono paternal não possui explicaçóes plausíveis, a morte violenta de Turno não possui justificati as. No entanto, a narrativa bíblica náo adquire o mesmo impacto que Eneida. Em nenhum momento Abraáo hesita, o que o torna mais semelhante a Odisseu, porquanto nisso Job é mais próximo de Eneias, porque lamenta o seu destino a todo o instante. Os lamentos destes heróis, no entanto, divergem: Job não compreende porque é afligido, enquanto Eneias desejaria ter morrido a enfrentar aquelas adversidades. Percebemos que nessa analogia com as personagens bíblicas, Virgílio reuniu em Eneias os monólogos de Job e a missão triunfal de Abraão. O que falta em Abraão completa-se em Job, e vice-versa. Virgílio reúne ambos em Eneias.

Mesmo na hora da suprema exaltação patriótica, quando Anquises mostra a Eneias o aglomerado dos heróis nascituros, surge uma figura envolvida de uma sombra agourenta, Marcelo, um jovem de dezanove anos, condenado à inveja dos deuses ${ }^{59}$. "Marcelo é o símbolo das dores que a pax Romana há-de custar ${ }^{60}$." Marcelo é a frustração dos Romanos que nele depositaram a confiança de dias melhores. No entanto, Eneias venceu, mas ficou vencido. Eneias praticou uma acção de vingança individual contra um derrotado que pedia a clemência e a interrupção de todos os ódios. Eneias traiu o ideal anunciado por Anquises: parcere subiectis. O poema da construção da pax Romana termina com uma acção de truculência selvagem ${ }^{61}$.

Para Farron ${ }^{62}$, o combate entre Eneias e Turno está modelado no combate entre Aquiles e Heitor, mas, para Clausen ${ }^{63}$, a violência aplicada a Turno, e a ele sozinho, é uma inovação de Virgílio. Já vimos anteriormente que a inspiração trágica da

\footnotetext{
${ }^{59}$ Medeiros 199218.

${ }^{60} \mathrm{~V}$. Pereira 1992107

${ }^{61}$ Medeiros 199221.

${ }^{62}$ Farron 1982136.

63 Clausen 198789.
} 
Eneida vem sobretudo da tragédia grega; Maguiness ${ }^{64}$ afirma que Virgílio introduziu livremente dois episódios emprestados de Eurípides, Polidoro e de Andrómaca ${ }^{65}$, os quais, de acordo com a ciência aristotélica, são vítimas inocentes. Dido e Turno também são, o que deixa claro a contemplação trágica ${ }^{66}$.

No seu conjunto, Eneias é uma história de sucesso e uma trágica história de um insucesso; Virgílio extrai ambas as histórias das obras gregas: o sucesso das epopeias e o insucesso das tragédias: a Odisseia é relativamente uma história de sucesso, enquanto a Ilíada é uma história de triunfo militar. Já tragédias gregas como Medeia, Hipólito, Agamémnon, Ájax e Rei Édipo descrevem a degradaçáo e a ruína de personagens que não mereciam estas terríveis catástrofes; a tragédia de Alceste, na peripécia final, traz a salvação à heroína e a felicidade ao seu marido purgado dos seus defeitos pelas provas que sofreu. Tragédias como Filoctetes, Édipo em Colono e Prometeu Agrilhoado representam os triunfos morais ganhos no abismo dos sofrimentos ${ }^{67}$.

De resto, os heróis sucumbem na Eneida, mas não à hybris:

They only can scape tragedy because they do not succumb to hybris and the passions which perpetuate violence ${ }^{68}$. The mission of Rome is peace: the driving spirit of Turnus, Camilla, Nisus, Mezentius, Amata, as well as of Dido, is passion, and through passion, violence ${ }^{69}$.

Em todo o seu curso, o poema é a expressão da ideia de Roma e de Itália, e da sua missão pessoal ${ }^{70}$. A partir disso, presumimos que cada um dos heróis que sucumbem à morte se torna Pharmakós ${ }^{71}$ e que pode eventualmente sucumbir pela paixão.

\footnotetext{
${ }^{64}$ Maguiness 1963479.

${ }^{65}$ Personagens das tragédias Hécuba e Andrómaca.

${ }^{66}$ Maguiness 1963 480; Camps 196931.

${ }^{67}$ Maguiness 1963 480-481.

${ }^{68}$ Otis 196464.

${ }^{69}$ Otis 196465.

${ }^{70}$ Camps 196918.

${ }^{71}$ Por se tratar de um conceito que não é universalmente aceito, usaremos o termo de acordo com a definição de Frye 1957 41. "The Pharmakós is neither innocent nor guilty. He is innocent in the sense that what happens to him is far greater than anything He has done provokes, like the mountaineer whose shout brings down an avalanche. He is guilty in the sense that he is a member of a guilty society, or living in a world where such injustices are an inescapable part of existence".
} 
A dedicação extrema, o desejo de glória e uma insensata atracção pelos despojos levam Niso e Euríalo à morte. É por este motivo que Eneias reflecte tanto. Na obra é o único a fazê-lo. E fá-lo tantas vezes que se sente impedido de levar a cabo as suas refle ôes. Por isso, tantas indagaçóes ficam sem resposta, ao longo da epopeia. Para V. S. Pereira ${ }^{72}$, responder equivaleria a pôr em causa o que é, à primeira vista, o objectivo do poema: a exaltação da missão civilizadora de Roma. Estas perguntas sem resposta remetem-nos novamente aos constantes monólogos do patriarca Job.

Uma coisa se sabe sobre Eneias: ele sofre, mas obedece. Um exemplo de real desobediência pode ser observado no quarto livro, quando se deixa levar pelo amor a Dido. Esse quadro exibido é o momento representativo da fraqueza humana ${ }^{73}$. Medeiros percebeu outro momento de desobediência do herói, no instante em que convida os troianos vencidos a entrarem na batalha, repudiando a ordem de fugir para a busca de uma nova terra, conforme já citámos.

Eis a contradição de Virgílio: o objectivo do poeta era a criação de um poema de vida. No entanto, acaba por deixar uma obra que, a exemplo do seu encerramento, conjuga o verso e o reverso, vida e morte, expondo uma imagem de uma Roma embriagada de sangue de tantos quantos foram sacrificados em sua honra. Assim também foi para Turno, rei dos Rútulos, cuja longanimidade não foi suficiente para vencer um duelo singular que tinha já há muito um vencedor. Consciente da conturbação política da sua terra natal e das limitaçóes da acção humana, Virgílio transforma a sua epopeia: o herói central, esquecido das recomendaçôes paternais - respeitar aqueles que se submetem, - desfere sobre um varão curvado um golpe mortal de que a humanidade se envergonha, ainda mais quando se sabe que a clemência, a justiça e o perdáo eram prerrogativas generalizadas como virtudes necessárias ao momento político ${ }^{74}$.

Virgílio, enfim, deixa as deficiências do tempo presente invadir o universo primoroso do passado; Gonçalves Dias na intenção de criar uma "Ilíada Brasileira", uma espécie de "Gênesis americano", seguiria o seu exemplo...

\footnotetext{
${ }^{72}$ V. Pereira 1992116.

${ }^{73}$ Lewis 196666.

${ }^{74}$ Carvalho 2008 20-21.
} 
Capítul o III

Gonçal ves Dias: As c ontradiç ōes de um poet A ANTI-Épico 


\section{A procura do representante da naçáo brasileira}

Paguei bem caro esta momentânea celebridade, com decepçôes profundas, com desenganos amargos, e com a lenta agonia de um martírio ignorado.

Gonçalves Dias

A literatura brasileira, tal como as suas congéneres americanas, năo principiou por um período balbuciante, no que diz respeito à língua ${ }^{1}$. Tais congéneres americanas, de que nos fala Souza Pinto, tiveram início apenas num período clássico, com a língua definiti amente formada. Destes elementos americanos, destaca-se o indianismo, o mais típico daquele período.

$\mathrm{O}$ indianismo canta o índio nos seus costumes, superstiçóes e combates ${ }^{2}$, tornando-se, portanto, a realização mais fecunda do nacionalismo americano, inclusive do Brasil. $\mathrm{O}$ índio fora escolhido como representante legítimo da pátria; para Souza Pinto, o pau-brasil, que deu nome à terra, e o índio, primitivo habitante, eram as realidades nacionais ${ }^{3}$. Mas para Melatti ${ }^{4}$, o índio nascido no Brasil depois da posse portuguesa não deixa de ser brasileiro. Aliás, não é mais brasileiro que o negro e o branco que colonizaram a terra. Antes que o Brasil se formasse, os indígenas estavam lá. $\mathrm{O}$ Brasil formou-se à custa das conquistas dos territórios desses povos. Aqueles que náo morreram tiveram que se submeter. No entanto, Souza Pinto também pondera o falso ponto de partida, porque o indianismo esqueceu que o americano, tal como no presente se afirma, náo é descendente directo do índio, mas do europeu transladado ${ }^{5}$, e de outros povos que para lá migraram.

Houve um choque entre os colonizadores e os indígenas: estes foram relegados para o interior do continente e os que não foram dizimados foram mantidos numa relaçáo de dependência que acabou por destruir tudo o que poderiam oferecer. Passaram

\footnotetext{
${ }^{1}$ Souza Pinto 19285.

${ }^{2}$ Souza Pinto 19285.

${ }^{3}$ Souza Pinto 19286.

${ }^{4}$ Melatti 1987195.

${ }^{5}$ Souza Pinto 1928 6-7.
} 
a representar o elemento marginal, sem tomarem a palavra no processo de colonização ${ }^{6}$, ao passo que o elemento negro participou activamente da colonizaçáo brasileira. Mas o negro não podia ser tomado como assunto, e muito menos como herói, náo porque teria sido submisso, passivo, conformado (conforme alguns estudiosos afirmam), como se fosse uma ideia generalizada da sua classe. Efectivamente, o exemplo de Zumbi dos Palmares ${ }^{7}$ e tantos outros demonstraria que a escravidão não fora um processo assim tão fácil de ser mantido. $\mathrm{O}$ negro não poderia ter sido escolhido, porque representava a última camada social, aquela que só poderia oferecer trabalho e para isto era orientada. Numa sociedade baseada na escravatura semelhante àquela em que vivia Gonçalves Dias, honrar o negro e valorizá-lo seria uma heresia ${ }^{8}$.

Sob a óptica de Orico, podemos perceber por que motivos teriam os indianistas optado pelo índio. A união com os chefes indígenas era a única possibilidade de os portugueses se estabelecerem na nova terra; nomes de índios notáveis, como Pirajobe, Tabira, Zorobabé, Tibireçá, significa am milhares de soldados ao serviço dos portugueses. A partir disso, diz-nos Orico, o índio brasileiro foi um elemento essencial na construção do país, náo pelo que representou ou poderia representar de romântico ou sugestivo, mas pela força de uma necessidade económica e guerreira, para a qual era ele o mais apto a comemorar'. Seria, pois, um erro afirmar que o índio náo participou activamente da colonização - o indígena aliado - uma vez que esta apenas se tornou possível pelo seu contributo.

No entanto, Gonçalves Dias inaugura uma nova vertente no indianismo, a do índio revoltado. Mas porque não teria optado Gonçalves pelo europeu ou pelo africano? De facto, o negro, por vezes, é apresentado na poética gonçalvina. Todavia, figura através da presença vaga de escravos atormentados, que sofrem às mãos de senhores impiedosos e cruéis, enquanto recordam com nostalgia uma África idílica ${ }^{10}$. Também não canta o negro quilombola, o revoltado; o próprio acto de recordar uma terra distante por si só já revela a razáo por que o negro não pode ocupar esta vertente gonçalvina. Restou ao seu dispor o conquistador e o primitivo.

\footnotetext{
${ }^{6}$ Sodré 1969165.

7 Último líder do Quilombo dos Palmares.

${ }^{8}$ Sodré 1969168.

${ }^{9}$ Orico 1930 37-38.

${ }^{10}$ Ventura 199146.
} 
Ao contrário de Virgílio, que cantou os feitos dos troianos conquistadores das terras do Lácio, sucumbindo às populaçôes locais, Gonçalves escolheu o índio, porque fora ele o adversário comum do português colonizador - ele que livre e dono da terra, se opusera ao domínio lusitano, lutara contra ele, e fora derrotado, combatendo-o ${ }^{11}$. Gonçalves tem um motivo para náo optar pelo mesmo elemento que Virgílio. Os troianos não tinham pátria. Haviam-na perdido e conquistaram-na no Lácio. Já os portugueses não precisavam conquistar terras, porque tinham uma pátria. Virgílio não canta a expansão, mas a fundação do Império Romano. Gonçalves Dias segue o exemplo, cantando a fundação de uma nova nação; porém a partir de uma vertente totalmente diferente, a sua premissa é a da visão dos povos derrotados.

Gonçalves Dias usa o arquétipo virgiliano na constituição do seu indianismo, pois as ambiçóes épicas de Virgílio estão enraizadas profundamente na actualidade histórica. Brisson confirma esta óptica ao afirmar q

Virgile n'est pas venu à l'épopée en un temps d'expansion de la cité romaine; son imagination créatrice n’a pas été stimulée par une poussée dynamique de la société où vivait; au contraire: ce qui a éveillé en lui le sens épique, ce fut l'apaisement, après bien des espoirs déçus, d'une longue et chaotique période de mutations, génératrice d'angoisse pour ceux qui essayaient d'envisager l'avenir ${ }^{12}$.

O sentimento épico de Gonçalves Dias também não é despertado pela expansão e ocupação das terras brasileiras. O que o despertou foi o sonho de liberdade possível; o Brasil vivia o segundo momento da sua independência. Tenha-se em conta que, no primeiro momento, o monarca era um lusitano, descendente primário da casa real portuguesa. Foi, portanto, no segundo momento que os brasileiros se sentiram independentes de Portugal. E após tantas esperanças desiludidas, a conquista do objecto desejado incentivou os nossos românticos a regressarem aos primórdios da nação. A reconquista da liberdade provocou uma nostalgia daquilo que haviam perdido. Referimos a liberdade anterior à chegada dos portugueses.

Se para Melatti, os índios são tão brasileiros quanto os negros e europeus, para Gonçalves o índio é, de alguma maneira,

${ }^{11}$ Sodré 1969279.

${ }^{12}$ Brisson 1966265. 
mais brasileiro, porque é a essência; Parry também observa que os primitivos habitantes do Lácio são, de certa forma, mais italianos do que os romanos ${ }^{13}$. No caso da opção de Gonçalves, os habitantes daquelas terras acabaram de conquistar a liberdade em relação à metrópole. No entanto, anterior à opressão, outros habitantes viveram em liberdade, e morreram por ela. Gonçalves segue o fio dessa ordem, recordando o tempo em que tais naçóes viviam livremente. As palavras de Evaristo da Veiga "Ou ficar a pátria livre ou morrer pelo Brasil ${ }^{14 "}$ tornam os índios o principal exemplo, porque o "morrer pelo Brasil" é morrer pela liberdade, pela posse da terra.

Para Quinn ${ }^{15}$, Virgílio é assaltado por duas problemáticas, a artística e a moral. Mas o poeta supera o seu dilema artístico, encontrando uma maneira técnica de fazer a escrita de valor no poema; e, por sua vez, resolve o problema de ordem moral, encontrando um artifício para fazer o poema extrair algo de valor historicamente ${ }^{16}$. Virgílio resolve este conflito nas primeiras linhas do poema. Gonçalves Dias também é tomado por este dilema, e, à semelhança de Virgílio, supera o seu problema artístico e moral:
Os ritos semibárbaros dos Piagas ${ }^{17}$,
Cultores de Tupã, e a terra virgem
Donde como dum trono, enfim se abrira
Da cruz de Cristo os piedosos braços;
As festas, e batalhas mal sangradas
Do povo Americano, agora extinto,
Hei de cantar na lira. (OT i.1-7)

Gonçalves tem de lidar com problemas de duas vertentes. Por um lado a complexidade de refazer as imagens do índio; porque ganharia outras significaçôes, para além daquelas que a experiência da administração colonial havia criado: do índio como bárbaro inimigo e escravo, como gentio, do índio como uma populaçáo a ser assimilada, do índio como uma alegoria da América ${ }^{18}$. A tarefa era construir um campo literário e intelectual

13 "They were somehow more Italian than the Romans themselves". Parry 196660.

${ }^{14}$ Este trecho corresponde ao refrão do Hino da Independência do Brasil.

${ }^{15}$ Quinn 196834.

${ }^{16}$ Quinn 196840.

${ }^{17} \mathrm{O}$ mesmo que pajé, tido como chefe espiritual indígena, misto de sacerdote, profeta e curandeiro.

${ }^{18}$ Kodama 200523. 
autonomizado da antiga metrópole. A imagem do índio como uma forma de expressar as particularidades do Brasil, ligadas às origens do que se tornaria a "Naçáo Brasileira"19. Por outro lado, refazer a imagem do colonizador; visto, anteriormente conforme expressa a carta de Pêro Vaz de Caminha - como o salvador daquela pátria e daquela gente, dando-lhe uma nova configuraçã . Ou seja, Gonçalves Dias deveria fazer uma inversão de valores, entre o índio e o colonizador.

Essa inversão de valores remete o poeta para o conflito de civilizaçôes na dimensão de tragédia ${ }^{20}$. A explicação que Bosi ${ }^{21}$ dá para o facto de Gonçalves se ter associado à cultura indígena, tentando, com isto, mostrar a face oculta da colonizaçáo, está no facto de o poeta ter nascido sob o signo de tensóes locais antilusitanas, que vão da independência aos Balaios, revolta popular no interior do Maranhão.

A paisagem natural passaria a servir como um sustentáculo que definisse, para a elite letrada, o conjunto de coisas consideradas como nacionais. Ao mesmo tempo em que se elegia a natureza do Brasil e os seus representantes directos - os índios - como símbolos nacionais, passava-se também a conhecer esta mesma natureza como uma aprendizagem material e científica dos elementos desta paisagem natural evocada, implicando este processo numa via de mão-dupla ${ }^{22}$.

Gonçalves, à semelhança de outros indianistas, impóe um certo olhar sobre a literatura nacional, tecendo sobre ela toda a urgência de um tempo histórico a ser vivificado, cujo fundamento de equivalência ao modelo das antigas naçóes estava nos elementos vistos como primordiais: a paisagem brasileira e, dentro dela, o índio ${ }^{23}$. O índio gonçalvino possui uma certa superioridade em relaçáo aos indígenas dos demais indianistas porque é mais autêntico. Mas o índio de Gonçalves Dias não é mais autêntico do que o de Magalhães ou o de Norberto por ser mais índio, mas por ser mais poético ${ }^{24}$. Para além de ser mais poético, Gonçalves tem ainda um grande trunfo, por ser, de entre os poetas indianistas, o que melhor compreendeu a cultura

\footnotetext{
${ }^{19}$ Kodama 200523.

${ }^{20}$ Bosi 2001184.

${ }^{21}$ Bosi 2001185

${ }^{22}$ Kodama 200527.

${ }^{23}$ Kodama 200526.

${ }^{24}$ Cândido 199375.
} 
indígena. No dizer de Antônio Cândido ${ }^{25}$, o valor de um escritor indianista é proporcional à sua compreensão da vida indígena.

${ }^{25}$ Cândido 199374. 


\section{A contradição da dialética gonçalvina}

"Quem sofre pode não ser poeta, mas o poeta... duvido que não sofra." Alexandre Teófil

Para Bosi, Gonçalves Dias é o primeiro poeta autêntico a emergir do Romantismo brasileiro ${ }^{26}$. De facto, aparece entre os quatro maiores nomes do indianismo, ao lado de Santa Rita Durão e Basílio da Gama (poetas da fase setecentista), e de Araujo Porto Alegre, seu contemporâneo ${ }^{27}$. Para Valverde ${ }^{28}$, Gonçalves Dias surge no início da poesia do Brasil como alguém que faz renascer, na literatura americana, as tradiçóes pré-colombianas. Para Veríssimo ${ }^{29}$, Gonçalves é um dos raros, se não foi o único, dos nossos que, com os dons naturais para o ser, a vida fez poeta. Não foi a moda, a retórica, a camaradagem, a presunção, nem sequer algum estímulo vaidoso, interesseiro, ou sequer patriótico, que fi eram de Gonçalves um poeta, mas sim a dor e o sofrimento.

De facto, Veríssimo estava pautado nas próprias afirmaçóes do poeta; eis a asseveraçáo sublime que o próprio pronunciou, no prólogo dos Últimos Cantos:

Desejar e sofrer - eis toda a minha vida neste período; e estes desejos imensos, indizíveis e nunca satisfeitos, - caprichosos como a imaginação, - vagos como o oceano, - e terríveis como a tempestade; e estes sofrimentos de todos os dias, de todos os instantes, obscuros, implacáveis, remanescentes, - ligados a minha existência, recontrados em minha alma, devorados comigo - umas vezes me deixaram sem forças e sem coragem, e se reproduziram em pálidos refle os do que eu sentia, ou me forçaram a procurar um alívio, uma distração no estudo, e a esquecer-me da realidade com as ficçóes do idea ${ }^{30}$.

O poeta referia-se obviamente ao afastamento da terra em que nascera; à perda do pai, ao isolamento em terra estranha, à

\footnotetext{
${ }^{26}$ Bosi 2004104.

${ }^{27}$ Valverde 1997114.

${ }^{28}$ Valverde 1997118.

${ }^{29}$ Veríssimo 1916249.

${ }^{30}$ Gonçalves Dias 1998369.
} 
amargura de seu nascimento mais que humilde, ao sentimento da sua inferioridade social, que contrastava com a sua fidalguia moral e mental; referia-se ainda à humilhação de viver à custa dos amigos; à penúria de recursos e mesquinhez da vida; à recusa em unir-se à mulher amada por causa da razáo do seu nascimento ${ }^{31}$; à própria estatura do poeta, com seu metro e meio ${ }^{32}$.

A consciência que tem da sua inferioridade é o que mais o atormenta, declara a José Joaquim Ferreira do Vale: "Sou fatalista no que diz respeito à minha vida, e resolveu-me sempre a fatalidade em fazer por fim o que náo quisera ${ }^{33 "}$; era fatalista porque sabia o que o aguardava. Sabia que o pedido de casamento poderia ser recusado. E, como se a família Ferreira Leal náo percebesse, fez questáo de afirma, primeiro na carta à mãe da Ana Amélia e, posteriormente, na correspondência com o irmão da mesma (desta vez com maiores requintes): "Sabes que não tenho fortuna, e que longe de ser fidalgo de sangue azul, nem ao menos sou filho legítimo ${ }^{34}$."

$\mathrm{O}$ poeta parece buscar na consciência da inferioridade uma compaixão, e esta comiseração seria cobiçada ao longo de sua vida. Posteriormente, num encontro com Ana Amélia, faria o seu 'último' harpejo, implorando a compaixão, - ao menos da mulher amada - uma vez que a família a havia negado.

Para além das tribulaçóes que conhece em vida, o poeta vive também os seus momentos de glória ao tornar-se o maior poeta de seu tempo. Gonçalves náo se restringiu apenas à poesia tentou figura -se nos diversos âmbitos da cultura intelectual do país, o que fez dele (aos olhos do público) um poeta de diversas faces. Sobre as outras faces do poeta, nos diria Coutinho ${ }^{35}$, Gonçalves cultivou com igual grandeza o lírico, o épico e o dramático; ensaiou prosa poemática que originou o verso livre; criou uma linguagem poética característica nas Sextilhas de Frei Antão, agitando a questão prosa-poesia no drama, como se nota no prólogo de Leonor de Mendonça; elaborou um dicionário de Tupi. Foi historiador, teatrólogo, etnólogo.

O poeta apresentava-se muito diverso de si, em cada criação, desejando ter usado vários heterónimos, conforme queria a

${ }^{31}$ Veríssimo 1997249.

32 Bandeira 199824 (a).

33 Gonçalves Dias 1998 1074. Em correspondência ao irmão de Ana Amélia Ferreira do Vale, na ocasião do pedido de casamento.

${ }^{34}$ Gonçalves Dias 19981074.

${ }^{35}$ Coutinho 1986123. 
princípio fazer nas Sextilhas, assinando-as com o nome de Frei Antão de Santa Maria de Neiva. O dualismo de cultura produziu o dualismo de personalidade, e a prova disso foi o facto de ter escrito inúmeros poemas que, ao invés de assinar, publicou como "traduzidos". Coutinho ${ }^{36}$ indaga: "Traduzidos por quem? Naturalmente por algum colega de Frei Antáo... ${ }^{37}$."

Este constante interesse pelos heterónimos faz jus à sua própria obra. Consciente o poeta, de sua inferioridade e sofredor, tenta sobrepor este sentimento à própria consciência que tem dele como se este acto anulasse quaisquer resquícios de sofrimentos. Parece navegar por dois extremos e confundir-se por eles, tal como escrevera ${ }^{38}$ a Henriques Leal: "Eu náo choro por mim; sou homem, disperso de grandezas, e, quando sofro, sou desmentido por minhas palavras, que nunca denotam sofrimento." Embora, na cart, o poeta falasse dos sentimentos amorosos, nela também declara o sofrimento sem esperança - "Tu não sabes o que é amar sem esperanças! ${ }^{19}$ " Toda esta prefiguração nos diz muito do poeta, na tentativa de construir uma obra genuína, de americanidade, do brasileirismo de que fala Alexandre Herculano ${ }^{40}$.

Gonçalves Dias era um misto entre o optimismo e o pessimismo, conforme ressalta Bandeira ${ }^{41}$ :

Mas aquele homenzinho de um metro e cinqüenta, que em versos moles ou na correspondência íntima, tanto se queixava, e remoendo a sós os seus desgostos emprestava-lhes as proporçóes de irremediáveis desgraças, crescia muito acima do estaláo comum nos atos de sua vida, sempre reveladores de forte vontade, sereno estoicismo e extraordinária resistência. Em agosto falava de suicídio, e no mês seguinte empenhavase nas eleiçôes municipais em favor de seus amigos cabanos.

O poeta, no entanto, tentava ignorar esta face oculta, nutrindo sonhos de grandeza e de glória. Surge entáo o interesse de uma grande proeza, desta feita a produçáo daquilo a que ele denominava "Ilíada Brasileira"; numa carta de mil e oitocentos e quarenta e sete, deixa claro a Henriques Leal o seu objectivo, chegando a anunciar elementos pitorescos, americanos, que utilizaria no

\footnotetext{
${ }^{36}$ Coutinho 1986123.

${ }^{37}$ Ricardo 1964138.

38 Souza Pinto 1931 15-16.

${ }^{39}$ Souza Pinto 193115.

${ }^{40}$ Herculano 1998 97-100.

${ }^{41}$ Bandeira 199824 (a).
} 
poema: imaginava um poema com magotes de tigres, quatis, cascavéis; mangueiras, jabuticabeiras, jequitibás, ipês arrogantes, sapucaieiras, jambeiros, palmeiras (é na referência a esta árvore que percebemos a estreita relação do poeta com a palmeira, como elemento da sua terra, pelo que diz: "de palmeiras nem falemos", como se este fosse o elemento primordial). E a série continua com guerreiros diabólicos, mulheres feiticeiras; sapos e jacarés. A sua futura obra defin -a como "gênesis americano" e "Ilíada brasileira", "criação recriada" 42 . Pensava que os acontecimentos teriam início no Maranhão e terminariam no Amazonas com a dispersão dos Timbiras, descrevendo as guerras entre os indígenas, e também contra os portugueses ${ }^{43}$.

O objectivo de compor uma "Ilíada Brasileira" é uma contradição que Gonçalves tem de vencer, uma vitória, a julgar impossível, e por ela sucumbe. O poeta tinha apenas um fim preciso, o épico, e na procura pelo épico tornou-se um antiépico. Coutinho ${ }^{44}$ traz-nos uma resposta plausível: "Nos poemas de Gonçalves Dias não faltarão lágrimas.” O pessimismo de $O s$ Timbiras tem na sua própria intenção a sua atitude poética de "cantor de um povo extinto ${ }^{45}$." Diria ainda "humilde cantor."

Há uma disparidade exorbitante entre a Ilíada e a intenção criadora de Os Timbiras: primeiro, porque a obra homérica lida com um exército à beira das muralhas de Tróia, de onde acaba por sair vitorioso. Já no caso de Os Timbiras, o poeta tinha um recurso bastante contundente, pois tratava-se de um exército derrotado que, penetrando por entre as brenhas amazónicas, fugia do invasor. Como se não bastasse, havia um elemento ainda mais complexo, com o qual nem Homero nem mesmo Virgílio, o exímio poeta, cantor dos troianos derrotados, responsáveis pela fundaçáo de Roma, tiveram de lidar. Porque, no caso de Gonçalves, o poeta teria de inverter os papéis na literatura já que, ao longo da cultura colonial, o índio era visto como um bárbaro, que deveria ser salvo pelos portugueses. Ou seja, o poeta tinha ainda de fazer uma inversão de valores. No entanto, na altura dos primeiros anos da independência brasileira, tal facto não seria demasiado complicado, uma vez que a lembrança do colonizador ainda estava forte na memória dos brasileiros.

\footnotetext{
${ }^{42}$ Moisés 198936.

${ }^{43}$ Franchetti 200762.

${ }^{44}$ Coutinho 198682.

${ }^{45}$ Coutinho 198692.
} 
Machado de Assis ${ }^{46}$ também reconhece o pessimismo gonçalvino na destruição das tribos indígenas:

A aparição de Gonçalves Dias chamou a atenção das musas brasileiras para a história e os costumes indianos. Os Timbiras, I-Juca Pirama, Tabira e outros poemas do egrégio poeta acenderam as imaginaçôes; a vida das tribos, vencidas há muito pela civilização, foi estudada nas memórias que nos deixaram os cronistas, e interrogadas dos poetas, tirando-lhes todos alguma coisa, qual um idílio, qual um canto épico.

Mas a contradição estava lançada. Gonçalves desliza pelos fios do épico para o antiépico. Virgílio, a exemplo do que vimos, tornou-se antiépico, por caminhar entre o optimismo e o pessimismo; em Gonçalves isto seria inevitável. Virgílio ainda cantava um exército derrotado que conquistava uma nova terra, ou seja, um momento de vitória posterior à derrota, a procura de uma nova glória, e por sinal, maior que aquela alcançada entre as muralhas de Tróia; já o vate maranhense declara-se cantor de um povo extinto, ou seja, não há glória, não há futuro pujante, há apenas ruína, destruição e morte; os guerreiros vitoriosos hão-de comemorar, para depois sucumbir pelas armas do colonizador. No caso dos romanos, havia uma esperança, havia uma nova terra; já para os indígenas, não havia nem terra nem esperança.

Para Machado de Assis, os motivos indianistas eram inválidos. Afirma que

É certo que a civilização brasileira não está ligada ao elemento indiano, nem dele recebeu influ o algum; e isto basta para náo ir buscar entre as tribos vencidas os títulos da nossa personalidade literária ${ }^{47}$.

Isso, no entanto, não denegriu a intensa procura dos indianistas. Mas não justifica a criação de algo genuinamente nacional, porque para Machado de Assis não há literatura que seja inteiramente nacional e desligada de outras literaturas. De facto, ao optar pelas tribos vencidas, os indianistas inauguraram um novo elemento literário americano, semeado de sentimentos tão extremosos.

A explicação desta mescla de sentimentos tão diversos entre si está na vida do próprio poeta. Para Pizarro ${ }^{48}$, Gonçalves caminha

\footnotetext{
${ }^{46}$ Machado de Assis 19942.

${ }^{47}$ Machado de Assis 19942.

${ }^{48}$ Pizarro 197024.
} 
do optimismo para o pessimismo, o que pode ser exemplificado no poema Quadras de minha vida, onde o poeta lembra os tempos cheios de ilusóes; onde havia fé e restou o desengano. Após uma série de desilusóes, o poeta encerra o poema de maneira gloriosa. A morte antes temível, é vista como a válvula de escape: "Feliz quem dorme sob a lousa amiga"; e enxerga no sepulcro o asilo desejado.

Para Ricardo ${ }^{49}$, a vida de Gonçalves é um confronto entre alegrias e dissabores, em que as alegrias saem ganhando. Todavia, por maiores que sejam as compensaçóes, o poeta jamais chegou a conformar-se com a sua condição. Nada foi capaz de o fazer esquecer as humilhaçóes de um nascimento obscuro e desigual. Mas, no fundo, a dor foi benéfica até certo ponto, pois é pela dor, pelo sofrimento, pelos espinhos da vida a atravessar-lhe o coração, que o poeta nos arranca um grito que se chama ode ou poema.

Para Musset ${ }^{50}$, os poemas mais belos de um romântico eram os desesperados, os que chegavam ao extremo de despojarse da consciência estética para surgirem como pura expressão psicológica. Sodré ${ }^{11}$ lembra a condição que faz de Gonçalves um homem melancólico: a sua vida atribulada, cheia de desencontros, com triunfos a que fez jus, próximos de infortúnios que náo merecera. Sofreu pela origem familiar e pela raça, pela distância do lar e da pátria e com os enganos no amor. E tudo isso soube cantar, como jamais outro cantou no nosso idioma - "talvez só Camóes.” Para Ricardo ${ }^{52}$ não há dúvida de que a fonte de inspiração está no sofrimento decorrente da auto-consciência do poeta.

Ackermann ${ }^{53}$ confirma o pressuposto: é possível que o poeta tenha sofrido muitas vezes com o desprezo de ser mestiço. «Prova disso é a dor maior, pelo pedido de casamento rejeitado», assim como o facto de a tragédia de Marabá reflectir a sua própria vida. O sentimento do poeta também é semelhante ao que encontramos em $O$ Canto do Indio: o "eu" lírico conta que, ao cair do sol, se sentiu atraído por uma jovem cristá que se banhava - nem seria necessário lembrar que o amor nascido no banho é uma invenção do romantismo europeu. $\mathrm{O}$ poema serve como configuraçáo do

\footnotetext{
${ }^{49}$ Ricardo 1964151

${ }^{50}$ Apud Cândido 199323.

${ }^{51}$ Sodré 1969283.

${ }^{52}$ Ricardo 1964150.

53 Ackermann 196496.
} 
mestiço que morre de amores por uma mulher que ele diz ser de "sangue azul" (será talvez necessário dizer que o poema se refere ao período anterior ao amor por Ana Amélia).

Mas se o nobre sentimento do poeta pode ser comparado ao amante de $O$ Canto do Índio, a sua disposiçáo de luta por este sentimento não é semelhante, porque no caso do índio, este menciona tudo aquilo que se submeteria de bom grado para conseguir o seu intento: tormentos e perigos, o sacrifício, não apenas da coragem, da força e da honra, mas ainda do seu ódio pelos cristãos, e até da sua própria liberdade ${ }^{54}$.

Marabá, de facto, não é apenas o retrato da índia que lamenta a falta de marido ou de pretendentes, mas é a própria projecção do poeta que no poema Ainda uma vez-Adeus manifesta o desgosto de o seu pedido de casamento a Ana Amélia Ferreira do Vale ter sido negado pela família da moça. Para Bandeira ${ }^{55}$, o motivo mais forte devia ser apenas a cor e a origem humilde do poeta, filho ilegítimo de Dona Lourença, porque aos vinte e oito anos Gonçalves era um homem glorioso em todo Brasil e Portugal. O poeta reage tal como o "Eu" lírico de Marabá: a mestiça não é capaz de tomar decisóes, frente à falta de pretendentes, porque não possuía uma linhagem original; o poeta também, "não foi capaz nem da indelicadeza de trair a confiança das famílias Leal e Ferreira do Vale, aceitando a solução de Ana Amélia, que propusera fugir com ele ${ }^{56}$."

Marabá não deplora um amor desdenhado, como a virgem indígena; o que ela lamenta é a sua solidão, a situação trágica que provém do seu nascimento, e a falta de amor, a que sempre está condenada e a que jamais poderá fugir ${ }^{57}$. O poeta por sua vez, lamenta "aqueles feros coraçóes, que se meteram entre nós." Lógico que por detrás de todo este sentimento, estava a mágoa de ter visto o seu casamento negado por ser mestiço. A sua dor chegara ao extremo de desejar a morte, mas a lembrança da mulher amada é o último arcar de esperança. A lembrança, aliás, é o tema central de toda a poesia gonçalvina. A lembrança da pátria distante, da mulher ausente, do passado pujante de um povo extinto, é o que move, no fundo, a sua máquina poética.

\footnotetext{
54 Ackermann 196497.

${ }^{55}$ Bandeira 199836 (a).

${ }^{56}$ Bandeira 199837 (a).

${ }^{57}$ Ackermann 196496.
} 
É pela sua mestiçagem e pelo conhecimento contíguo dos indígenas que Gonçalves recebe o grande impulso. O sentimento de inferioridade desperta nele a paixão pelo indígena brasileiro que, retaliado de todas as formas possíveis, se embrenha pela flo esta, fugindo do colonizador. Desde os primórdios da colonizaçáo, o índio fora visto como um elemento inferior. A instauração da Civilização faz-se à custa da morte dos "não-civilizados", e pela ocupação da terra pelos civilizados.

Gonçalves enobrece o índio. Sodré ${ }^{凶}$ todavia, questiona o enobrecimento de tais classes sociais, pela "sua "ociosidade", sua aversão a todo esforço disciplinado, sua 'imprevidência', sua 'intemperança', seu gosto acentuado por atividades antes predatórias do que produtivas - ajusta-se de forma bem precisa aos tradicionais padróes de vida das classes nobres." Gonçalves funda com seu indianismo um novo conceito de nobreza, o de nobreza do selvagem americano - embora em alguns momentos o poeta atribua aos índios virtudes convencionais de antigos fidalgos e ca aleiros europeus ${ }^{58}$.

Para Souza Pinto ${ }^{59}$, o indianismo traduz a pretensão de criar, para a América, uma epopeia americana, um passado lendário, que garantisse a autonomia do novo continente. É, principalmente, uma afirmação de continentalidade. E não se pode dizer que não seja nobre e legítimo tal propósito, visto que, invertendo todas as regras apologéticas, quer celebrar o triunfo dos vencidos - função que melhor competiria à tragédia.

$\mathrm{O}$ indianismo, portanto, baseia-se no interesse de construir um monumento literário inteiramente brasileiro, livre das convençóes portuguesas; mas ao tentar fazê-lo, Gonçalves entra em contradição. Os primeiros indianistas tentaram enaltecer o elemento indígena, mas Gonçalves queria ir além da celebração; queria um monumento literário semelhante às obras épicas, e que não ferisse o "código de ética" dos primitivos americanos. Porém, nos primeiros instantes da sua poesia, Gonçalves falhou. Embora os defensores mais sérios do indianismo gonçalvino declarem que o poeta tenha criado um indianismo único e não imitativo ${ }^{60}, O$ Canto do Índio parece trair toda esta convenção. O amor entre o indígena e o português já estava presente no Caramuru de Santa Rita Durão, e o próprio conterrâneo José Alencar representou

\footnotetext{
58 Sodré 1969276.

59 Souza Pinto 19286.

${ }^{60}$ Coutinho 1986115.
} 
isto muito bem em $O$ Guarani e Iracema ${ }^{61}$. No entanto, nas obras posteriores, esta falha é corrigida, embora isso não signifique que Gonçalves tenha alcançado a literatura genuinamente brasileira. Porque, a exemplo das palavras de Machado de Assis ${ }^{62}$, não existe literatura que seja genuína e exclusiva de uma nação, desconexa das demais.

Gonçalves exibe uma extracção neoclássica nos versos. A sua linguagem e o seu estilo mostram-se firmemente entroncados na tradição portuguesa. $\mathrm{Na}$ carta que acompanha Iracema, Alencar critica Gonçalves Dias, porque os índios gonçalvinos tinham uma linguagem muito clássica, não porque esperava que eles falassem tupis, mas que, à semelhança dos seus índios, usassem termos e frases que ao leitor pareceriam naturais na boca do selvagem ${ }^{63}$. $\mathrm{O}$ poeta utiliza pouco este instrumento, à excepção de Os Timbiras, e nalguns trechos (raros) de poemas diversos.

Segundo Valverde ${ }^{64}$ :

Y en esas obras el poeta brasileño ya revelaba un indianismo que era, antes que nada, exigencia interior em quien había nacido hijo de português y de brasileńa descendiente de indígenas. Por otro lado, Gonçalves Dias estaba tan atento al trabajo formal y a la tradición de su lengua literaria que uno de los primeros elogios públicos a su obra vino de Portugal y de un escritor con la autoridad de Alexandre Herculano.

Embora muito se diga que Gonçalves terá sido o primeiro autêntico poeta indígena, a verdade é que nem mesmo aqui a visão do índio se consuma, porque não é propriamente o índio quem fala. $\mathrm{O}$ facto de o poeta ser mestiço é por si só fruto da colonização que eliminou o indígena. Ou seja, a visão do índio em Gonçalves Dias, ainda é a visão que o europeu lhe deu. Mais que isso, ressalta Herculano ${ }^{65}$, o poeta tem muito de português no trato da língua e nas cadências garrettianas do lirismo, ao contrário de seus conterrâneos que eram influenciados pela literatura francesa.

Estas contradições no âmbito de constituir uma literatura inteiramente brasileira são perceptíveis desde o primeiro poema indianista de Gonçalves Dias: a metáfora da natureza edénica

\footnotetext{
${ }^{61}$ Ackermann 196497.

${ }^{62}$ Vide nota 46 p. 57.

${ }^{63}$ Franchetti 200761.

${ }^{64}$ Valverde 1997117.

${ }^{65}$ Bosi 2004105.
} 
exprime a ideia de identidade colectiva, e pode ajudar no entendimento da urgência romântica em criar uma literatura propriamente nacional ${ }^{66}$. Mas esta natureza edénica causa algum estranhamento em Gonçalves Dias. Em mil e oitocentos e quarenta e cinco, de Caxias, numa carta a Alexandre Teófilo de Carvalho Leal, diz o poeta: "sozinho em terra que, apesar de minha, eu posso chamar estranha ${ }^{67}$ ”... O poeta sentia saudades da cultura letrada, da voz do entusiasmo e da poesia, e acabaria por trocar as terras de palmeiras pela então capital imperial, Rio de Janeiro.

As contradiçóes não estão apenas na natureza edénica, pois para Valverde ${ }^{68}$, a Canção do Exilio é "la posible alusión encubierta, referida anteriormente, al «sabiá» como rival americano del ruiseñor." Partimos entáo para o pressuposto de que toda a obra é imitativa. Martindale ${ }^{69}$ observa que a tensáo encontrada na Eneida influenciou muitos escritores posteriores a Virgílio. O optimismo e o pessimismo são as duas grandes vozes analisadas por Parry ${ }^{70}$, "a public voice of celebration and an elegiac private voice of lament." Obviamente que a obra de Gonçalves não poderia ficar ilesa, já que se tratava de conquistadores e conquistados, semelhante à Eneida.

Que a poesia latina exerceu uma influência sobre os povos ocidentais desde a conquista dos romanos no Lácio não é novidade ${ }^{71}$. Embora Gonçalves Dias tendesse a construir uma "Ilíada Brasileira", acabou por nos deixar, no conjunto de seus poemas, uma "Eneida Brasileira", já que a Eneida virgiliana canta o nascimento de um novo povo, de um novo império, construído a partir das cinzas de outro povo, de outro império ${ }^{72}$, ainda que essa construção pertença a um povo vencido, cujo primeiro império sucumbiu com as muralhas da cidade. Pelo contrário, e conforme já dissemos, o monumento literário de Gonçalves celebra antes o triunfo das tribos vencidas.

Seria esta, ainda assim, uma imitação da obra virgiliana. De acordo com Martindale ${ }^{73}$, todas as leituras de textos estão situadas

\footnotetext{
${ }^{66}$ Marques 2003 79-80.

${ }^{67}$ Gonçalves Dias 19981041.

${ }^{68}$ Valverde 1997119.

69 Martindale 199340.

70 Parry 1966.

${ }^{71}$ Martindale1993 p. XIII.

72 André 199247.

${ }^{73}$ Matindale 199335.
} 
de acordo com o momento histórico, ou seja, a compreensão de uma obra é feita historicamente, já que todo o texto é imitativo. Partimos dessa premissa para firmar que os grandes textos são releituras, isto é, releitura dos trabalhos que imitam. Logo, a cada releitura, um novo elemento é incorporado, cada um condizente com o seu momento histórico.

A obra de Virgílio parece ter alcançado em Gonçalves Dias uma maior intensidade pessimista e, em menor dimensão, laivos optimistas. Tenhamos em conta que os indígenas foram extintos, ao passo que os romanos conquistaram uma nova pátria. Contudo, o grande optimismo de Gonçalves está na morte gloriosa, no campo de batalha, no acto de morrer pela liberdade e não se deixar submeter à lei escravocrata dos colonizadores, tal como todo índio almejava. Morrer na batalha, aliás, nas culturas primitivas, era a maior honra que um homem poderia alcançar. Numa sociedade como a indígena isto seria primordial. 


\title{
3. Tabira: o retrato da uniáo entre o índio e o europeu
}

\author{
"E o sangue dos caciques escorreu feito água, \\ o pátio virou uma imensa pocilga \\ a fedentina subia sangue \\ enquanto intestinos se arrastavam pelo chão com seus feridos." \\ Bernardino Sahagún
}

Os poemas indianistas apresentaram três fases distintas: paradisíaca, guerreira e agónica. Nas duas primeiras fases, o poeta desconstrói a visão colonialista acerca do universo nativo, valorizando-o e identificand -se com o que antes era repudiado. Porém, a terceira fase distingue-se claramente, por serem poemas que narram o encontro entre os europeus e os nativos, mostrando o que se escondia por detrás da capa do progresso e do civilizador. De acordo com Andrey ${ }^{74}$, podemos indicar Marabá, O Canto do Índio e Tabira como exemplos dessa fase, juntando a estes o poema Visóes, um dos poemas publicados postumamente.

Tabira é um poema épico composto por vinte e cinco oitavas de versos eneassílabos de ritmo anapéstico. O poema, cujo herói principal tem o nome estampado no título, narra o combate entre as tribos Tabajaras e Potiguares. A guerra entre os Tabajaras e os Potiguares, de acordo com Orico ${ }^{75}$, foi a mais grave e a mais sangrenta de toda a conquista do território, pela resistência que se encontrava de ambos os lados. Para Franchetti ${ }^{76}$, Tabira está mais próximo do modelo épico do que I-Juca Pirama, porque desenvolve um conteúdo histórico ou mítico, mas ambos os textos são singulares, porque permitem ao leitor perceber, na consideraçáo do escopo do título, a diferença de tratamento da maneira heróica.

Gonçalves Dias utiliza uma forma técnica na produção de Tabira. Os recursos moral e artístico de que fala Quinn ${ }^{77}$, foram explorados apenas em benefício da poesia. Confrontando o interesse histórico e o interesse poético, o poeta fez uma inversão de valores, aquando

\footnotetext{
${ }^{74}$ Oliveira 2005 39-40.

75 Orico 193035.

${ }^{76}$ Franchetti 200763.

77 Quinn 196834.
} 
do evento da produção de Tabira. Para Ackermann ${ }^{78}$, não há dúvidas de que a guerra entre os Tabajaras e Potiguaras constitui o principal motivo de composiçáo, visto que o próprio poeta documentou a veracidade dos factos. Mas Gonçalves fez uma inversão dos factos: a afirmação de que os Tabajaras eram os vencidos deixa perceber a simpatia do poeta pelos Potiguaras.

Apesar de contraditória, e de suscitar inúmeras suspeitas, a alteraçáo dos factos dentro do poema deixa transparecer a ideia de que o que vale na obra artística não é a verdade histórica, e sim a verdade poética. Aliás, em diversos momentos, o poeta utilizaria os recursos históricos apenas no benefício da poesia.

Tabira possui todas as características de um herói épico. As primeiras palavras do poema denunciam as suas qualidades de chefe e soldado.

À semelhança dos heróis gregos e romanos, Tabira só tinha um dom: o de vencer batalhas. Se, na Eneida, Virgílio expressava a contradição entre o canto glorioso e o canto da dor humana, usando mecanismos exclusivos do género épico ${ }^{79}$, a gloriosa batalha e a expressão pujante da morte de Tabira são prenúncios da ruína e da extinção dos povos indígenas.

Num dos poucos poemas onde Gonçalves reúne o negro e o índio, o poeta utiliza uma epígrafe, confrontando o destino destes povos:

Les peaux rouges, plus nobles, mais plus infortunées que les peaux noires, qui arriveront un jour à la liberté par l'esclavage, n'ont d'autre recours que la mort, parce que leur nature se refuse à la servitude.

Antes que o leitor tenha contacto com o poema, Gonçalves faz uma advertência, não apenas para o que está no poema, mas para o que o conjunto da sua obra denuncia: a morte e a extinção dos povos americanos. O desconhecido autor da epígrafe afirma que os índios eram mais nobres do que os negros. Porém mais desafortunados, porque os negros um dia alcançariam a liberdade da escravidão, ao contrário do índio que, em virtude da sua natureza, recusava a servidão, não restando outro recurso que não fosse a morte.

As configuraçóes épicas de Tabira denunciam que cumpria as partes de chefe e soldado, semelhante a Agamémnon, chefe de todos os Aqueus, que também entra em batalha. Ninguém

${ }^{78}$ Ackermann 1964 102-103.

${ }^{79}$ Carvalho 200878. 
mais que Tabira observava o tratado. Os primeiros cronistas da colonização tinham percebido a fidelidade dos índios, exaltando-a como superior à fidelidade dos europeus. Já Homero havia dado estas mesmas características aos seus heróis: Penélope mantém-se fiel ao marido, durante todos os anos que este esteve ausente; mesmo quando não tinha notícias do paradeiro do esposo, não cedeu aos interesses dos pretendentes. A lealdade de Penélope significa a uma uniáo matrimonial até à morte, ao passo que a lealdade e o respeito pelos tratados de que dispunha Tabira escondia a sua ingenuidade e estupidez ${ }^{80}$.

Lery ${ }^{81}$ observa a facilidade de se construir amizade com os indígenas e assinala que quem quiser ser amigo, tanto dos velhos quanto das crianças, nada lhes deve negar. Na verdade não eram ingratos, principalmente os velhos, pois quando menos pensamos no obséquio, eles lembram o donativo e retribuem com qualquer coisa. Os selvagens não dão nada sem que recebam; segundo Lery, se alguém lhes fi er recusa, nunca mais esquecem o facto ${ }^{82}$. Por outro lado, por menos que sejam ultrajados, jamais perdoaráo a ofensa. Os índios adquirem e conservam esta obstinação de pais para filho ${ }^{83}$. O que se percebe é que os índios eram fiéis aos seus sentimentos, fossem eles de amizade ou de inimizade. Ninguém menos que Tabira se aterrorizava diante dos perigos, nem corria mais depressa aos acenos da guerra; semelhante a Heitor que, mesmo conhecendo o destino, no caso de um confronto com Aquiles, não foge à luta, e no meio da batalha, procura o rei dos mirmidóes. Em tantas batalhas épicas, os maiores heróis eram os que melhor atendiam ao grito de guerra; assim é Tabira:

Ninguém mais observa o tratado,

Ninguém menos de p'rigos se aterra,

Ninguém corre aos acenos da guerra

Mais depressa que o bom lidador! (T 5-8)

$\mathrm{O}$ viver de Tabira era a batalha. O preparar a cilada onde o inimigo se viesse meter. Os tormentos causados aos inimigos atentavam para um facto que os Potiguares podiam testemunhar: "Que Tabira só sabe vencer!" (T 16). Por diversas vezes tentaram matar o chefe indígena. Os heróis gregos e romanos eram

${ }^{80}$ Oliveira 200552.

${ }^{81}$ Léry 1941151.

${ }^{82}$ Fernandes 1989262.

${ }^{83}$ Fernandes 1989262. 
protegidos por um deus que os amava, já o elemento indígena desconhece um panteáo semelhante ao dos gregos e latinos. Por isso, Tabira não podia ser protegido por um ser divino, mas havia no chefe e guerreiro uma espécie de feitiço, ou encanto, ou condão, porque todo o plano de morte era frustrado. As práticas antropofágicas dos indígenas tinham um objectivo. Ao digerir a carne do inimigo, o índio também digeria a sua virilidade, a sua astúcia, a sua força ou fraqueza. É possível que a protecção de que o chefe dispunha estivesse no facto de ter muito do inimigo dentro de si.

No meio dos versos de glória, surge a razão que conduzirá ao poema, o canto de dor e de morte:

Já dos Lusos o trôço apoucado,

Paz firmando com ele traidora

Dorme ileso na fé do tratado,

Que Tabira é valente e leal.

Sem Tabira do Lusos que fora?

Sem Tabira que os guarda e defende,

Que das pazes talvez se arrepende

Já feridas outrora em seu mal! (T25-32)

A guerra entre as tribos tinha apenas uma finalidade: vingar os pais e os amigos presos e comidos, no passado ${ }^{84}$. Os índios viviam em constantes batalhas; por causa das desunióes entre as tribos é que o elemento indígena foi extinto. Se os povos indígenas se tivessem unido em torno de um objectivo comum - expulsar o invasor - certamente os portugueses teriam tido maiores dificuldades em conquistar tais territórios. Porém, os índios eram muito atentos às alianças, e por esta razão a melhor de todas as armas para a conquista do selvagem era estar de bem com ele ${ }^{85}$. Além disso, reduzidos em número, os portugueses jamais poderiam vencer os indígenas sem a ajuda do indígena aliado $^{86}$. É mister na sua poética, que Gonçalves coloca, ao lado de índios valorosos como Tabira, sempre a imagem de europeus dominantes ${ }^{87}$. Cardim ${ }^{88}$ cita o exemplo dos índios de São Vicente que ajudaram os portugueses na conquista da terra, "pelejando

\footnotetext{
${ }^{84}$ Léry 1941168.

${ }^{85}$ Orico 193036.

${ }^{86}$ Orico 1930 36-37.

87 Souza Pinto 19287.

${ }^{88}$ Cardim 1939171.
} 
contra seus próprios parentes", entre outras nações indígenas, e testemunha que quase todos eram mortos e possuíam tanto medo dos portugueses que fugiam costa adentro até trezentas ou quatrocentas léguas.

De acordo com Florestan ${ }^{89}$, os papéis dos chefes indígenas referiam-se às relaçóes com os grupos tribais vizinhos e inimigos (guerra): punição de ofensas e homicídios (retaliação) e as formas tribais de dominação (gerontocracia). Tabira, portanto, é o elemento chave para se chegar à tribo, e a união com o dono da terra; quaisquer que fossem as vontades dos lusos, os indígenas obedeceriam apenas à vontade do chefe. Conquistá-lo significaria a conquista de toda tribo. Após a união com Tabira, os lusos dormiam ilesos na fé do tratado. O tratado de paz entre os povos primitivos sempre trouxe a ruína para um dos lados.

O Brasil é conquistado sob o poder da cruz de Cristo. A conciliaçáo entre Tabira e os portugueses sugere uma mensagem feliz, mas está envolvida na destruição desta civilização. Assim também Dido ama Eneias e desta união provém sua morte. "Desconhecedora do destino (seu, dos outros) como qualquer mortal, o seu coração que transborda de amor e a sua má sina conjugar-se-ão para alimentar uma esperança vá no amor de Eneias ${ }^{90}$." Tal sina também presidira à união de Eneias e Evandro, cuja união trouxe a morte de seu filho, enfim, a destruição no seio de sua nação; a união dos indígenas com os estrangeiros não teria melhor sorte.

Chefe stulto dum povo de bravos,

Mas que os piagas vitórias te fadem,

Háo de os teus, miserandos escravos,

Tais triunfos um dia chorar!

Caraíbas tais feitos aplaudem,

Mas sorrindo vos forjam cadeias,

E pesadas algemas, e peias,

Que traidores vos hão-de lançar! (T 33-40)

Eis a face do triunfo das tribos guerreiras. Não adiantava vencer os vis Potiguaras porque, no final da grande vitória, uma derrota os aguardava. Os Caraíbas aplaudiam a derrota dos Tabajaras no mesmo instante em que eram derrotados, porque as traiçóes dos lusos não eram apenas com os Tabajaras. Mas

${ }^{89}$ Fernandes 1989261.

${ }^{90} \mathrm{~V}$. Pereira 199291. 
tal sucedia aos Caraíbas e a todas as tribos que se interpusessem no meio do caminho. $\mathrm{O}$ poeta lamenta a imprudência do chefe dos Tabajaras porque, no final da batalha, os índios de Tabira seriam perseguidos pelas matas, feridos e sangrentos; porque não eram capazes de ser escravos e por isso acabariam por morrer, à semelhança do seu chefe.

A poética de Gonçalves engloba três raças distintas: brancos, negros e índios. Os negros foram denominados de homens de "pel' cor da noite" (T 49). A figura de linguagem gonçalvina tem uma particularidade comum aos indígenas, porque a noite tinha um significado ímpar. Durante o dia executavam-se todas as acçóes, todos os trabalhos. Mesmo as guerras apenas se realizavam ao brilho do sol. Os índios temiam a noite, de modo que, de entre as pouquíssimas coisas que eram efectuadas nesse período, as festas tinham lugar de destaque, no centro da Taba. Eis, pois, os elementos mais intimidantes para os índios: a parte do dia mais temível era a noite, ao passo que, da vida, a servidão era a pior hipótese de sobrevivência. Os negros tinham a pele da cor da noite, submetiam-se à servidão sob os açoites; mas o índio não era capaz disso, porque prezava poucas coisas e por elas dava a vida: as batalhas, as festas, os triunfos sangrentos e as sestas, resguardadas do sol nas aldeias.

Apesar do pessimismo no poema, surge um fio de esperança. Se não há outro caminho do que a servidão, o índio ama a vida, mas prefere morrer a viver amargos momentos: "Quer e pode e bem sabe morrer!” (T 64). O grande trunfo do optimismo gonçalvino está completamente expresso nesta frase. A esperança que nasce em cantar a extinção de um povo é exaltar que o índio escolheu a morte a viver o regime escravocrata imposto pelos portugueses.

Após os prenúncios de sofrimento para as tribos indígenas, em virtude da uniâo com o elemento invasor, o poeta leva-nos a uma nova dimensão, a do combate entre as tribos americanas. Surgem os Potiguaras ousados, que não são muitos, mas define se como briosos guerreiros. Os Potiguaras conhecem o inimigo e a fama que ele possui: Tabira já não reverenciava Tupã, pois tinha sido convertido ao cristianismo. De acordo com Kothe ${ }^{91}$, o catolicismo, a reconquista, as descobertas ultramarinas, a conquista e a colonização da América fazem parte do mesmo espírito grego, da mesma europeidade, porque, entre si, os povos europeus também praticaram isto. Deixemos a ambígua

${ }^{91}$ Kothe 1997247. 
afirmação de que Tabira não cria em Tupã, uma vez que os índios não tinham nenhuma divindade semelhante aos portugueses. No fundo, a religião que os Jesuítas trouxeram para os índios teve um significado muito semelhante ao do cavalo que os gregos deixaram diante das muralhas de Tróia: em ambos estava a morte.

$\mathrm{Na}$ décima primeira estrofe surge um índio de nome desconhecido, dos mais orgulhosos entre os Potiguaras, que subiu às pressas ao topo de um monte e ali bradou de frente com Tabira:

Ó Tabira, Tabira! aqui somos

A provar nossas forças contigo;

Dizes tu que vencidos já fomos!

Di-lo tu, não no diz mais ninguém.

Ora eu só a vós todos vos digo:

Sois cobardes, irmão de Tabira!

Propagastes solene mentira,

Que vencer não sabemos também.

"Para o vosso terreiro vos chamo,

Contra mim vinde todos, - sou forte:

Acorrei ao meu nobre reclamo!

Aqui sou, nem me parto daqui!

Vinde todos em densa coorte:

Travaremos combate sangrento,

Mas por fim do triunfo c uento

Direis vós, se fui eu quem menti. (T 89-104)

O índio desconhecido assume as prefiguraçóes de um herói homérico; seus heróis seriam ousados ao ponto de entrar na batalha ainda que lhes fosse desfavorável. Assim o fez Pátroclo, usando as armas de Aquiles para reclamar a si um duelo com Heitor, sabendo que a vitória seria impossível; mas assim também faria Heitor, mais tarde, ao combater com Aquiles. No discurso do índio desconhecido está a essência do optimismo do indianismo gonçalvino: a batalha tinha apenas um significado, o da honra, seja para os que pereceram em combate, seja para os vitoriosos.

$\mathrm{O}$ discurso do índio incita à ira de Tabira, em poucos instantes o extremo horizonte estaria cheio de guerreiros, não sendo possível distinguir no monte o que era gente e o que gente náo era. A imagem fornecida por Gonçalves é típica da que encontramos nos textos épicos antigos, cujo número de soldados era geralmente incalculável e não raro enchiam todo o vale ou a praia. A batalha deixou o cháo coberto de mortos, mas a peleja estava indecisa. 
No meio dessa guerra sangrenta, o poeta evoca o nome de Tabira "Onde agora se esconde o pujante?" (T 154). Tabira está no meio da batalha, sangrento, mas segue impiedoso andando adiante, deixando uma larga esteira de mortos pelo chão, como um raio cortando ramos e troncos, no bosque onde cai.

A figura de Tabira sangrento no meio da batalha é um símile de Agamémnon ferido no meio da guerra com os Troianos; o nobre guerreiro e chefe dos Aqueus retirou-se da batalha apenas ao cair da noite. Para Ackermann ${ }^{92}$, é forte a imagem de Tabira cravejado de setas e parecendo um porco-espinho. Sangrando, continua avançando contra o adversário, arranca sem dó o olho com a flecha que o feriu e exibe-o, para zombar assim do inimigo, que se enfurece ainda mais. Tais qualidades elevam a sua figura, de tal maneira que não é preciso temer comparação com algum herói homérico.

Foge! Foge! Leal Tobajara;

"Quantos arcos que em ti fazem mira?!"

- Muitos são; porem medos encara

- Face a face, quem é como eu sou! -

Muitas setas cravejam Tabira:

Belo quadro! - mas vê-lo era horrível!

Porco-espim que sangrado e terrível

Duras cerdas raivando espetou!

Tem um olho dum tiro flechado

Quebra as setas que os passos lh'impedem

$\mathrm{E}$ do rosto, em seu sangue lavado,

Flecha e olho arrebata sem dó!

$\mathrm{E}$ aos imigos que o campo não cedem,

Olho e flecha mostrando exto quidos,

Diz, em voz que mais eram rugidos:

- Basta, vis, por vencer-vos um só! (T 161-176)

A vitória para o índio não estava no número de mortos, mas sim na morte gloriosa, porque vencer apenas um inimigo já significa a por si tê-la alcançado. Tabira exibe o olho na flecha como quem levanta um troféu. A Eneida encerra com a morte impiedosa de Turno. O poema da pax romana termina com a cena mais brutal do poema. Turno e os Latinos estáo do lado oposto ao triunfo de Roma, por isso Turno é a última vitima e a mais importante de

${ }^{92}$ Ackermann 1964102. 
uma série de vítimas de Eneias ${ }^{33}$. Tabira poderia ser um poema inteiramente épico se terminasse com a morte do chefe indígena, porque aparentemente a sua morte é condicionada pela guerra comum entre as tribos, mas após a morte gloriosa de Tabira, o poeta lembra que os mortos deixados no campo de batalha são invejados pelos índios, que tanto amaldiçoam a escravidão. Insiste na ideia enunciada na legenda inicial, já uma vez repetida na sétima estrofe: o negro pode suportar aquele horror, mas o índio prefere a morte, a suportar a escravidão ${ }^{94}$.

Após este acto heróico de Tabira, a sua tribo, que estava em desvantagem, recobra o ânimo e triunfa no combate. No entanto, bem longe de trazerem de facto uma vitória, os triunfos da tribo Tabajara frente aos Potiguares dá origem à sua própria escravidáo, que é o pior dos fins que podem esperar os guerreiros indígenas. Considerando a escravidáo como o mais indigno dos destinos em oposição à honrosa morte em combate, os Tabajaras que, na última estrofe do poema, são descritos numa senzala em condição de escravos ao lado de negros africanos, invejam a sorte dos Potiguares, apesar de estes terem sido reduzidos de uma "nação numerosa e potente, a restos dum povo infeliz"."

Para Montesquieu, o direito de escravidão deriva do desprezo de uma nação pela outra, em que a diferença cultural serve como indício de inferioridade humana e social. Os índios não se submetiam à escravidão, não apenas porque conheciam a liberdade, mas também porque não aceitavam a condição de inferioridade. Tal convenção era fácil de ser percebida diante dos rituais de antropofagia, quando a vítima não temia a morte e incitava à ira os inimigos, mesmo quando já se encontravam irremediavelmente vencidos. Segundo Ventura ${ }^{96}$ a religiāo foi o meio utilizado para encorajar os destruidores da América, porque esta dá o direito de quem professa converter quem não professa.

$\mathrm{O}$ encerramento de Tabira possui conotaçóes semelhantes às do início de Eneida, quando Eneias chorava por não haver perecido junto das muralhas de Tróia; chorou também diante das pinturas de um templo em Cartago, que evocavam a guerra com os Aqueus; o choro de Eneias era sobre a sua sorte e a dos seus amigos ${ }^{97}$. O encerramento do poema de Gonçalves Dias

\footnotetext{
${ }_{93}$ Putnam 1989151.

${ }^{94}$ Ackermann 1964102.

${ }^{95}$ Oliveira 200554.

${ }^{96}$ Ventura 199120.

${ }^{97}$ Medeiros 199212.
} 
trouxe a parte mais sublime do pessimismo, o destino final dos sobreviventes:

Este o conto que os Índios contavam,

A desoras, na triste senzala;

Outros homens ali descansavam,

Negra pel'; mas escravos tấo bem.

Não choravam; somente na fala

Era um quê da tristeza que mora

Dentro d'alma do homem que chora

O passado e o presente que tem! (T 193-200)

O negro teve o seu espaço tardiamente na literatura; as raras vezes que Gonçalves usou os negros foi de uma forma idílica, lembrando a terra que tinham no além-mar. Mas, em geral, no poema gonçalvino, o negro tem de se contentar, no melhor dos casos, com a posição de vítima, vítima submissa ou rebelde ${ }^{98}$. Em Tabira, o negro assumiu esta conotação; o negro vive na senzala, e para lá é que vai o índio aliado.

Discorremos, um pouco, acerca da inversão que Gonçalves fi era nesta obra, e perguntamos quais seriam os motivos dessa inversão. O optimismo de Gonçalves está no índio que resiste ao colonizador, e a essência deste optimismo é a morte, em prol da causa comum. Não raro a morte por uma causa é o acto mais sublime que se pode alcançar. Assim como a morte de Cristo é a vitória do bem contra o mal, a morte do índio resistente é o símbolo da pureza indígena; ainda que signifique o abandono da mesma. O Potiguara que morre leva consigo a sua pureza; o Tabajara que fora transformado em escravo, perde sua virtude. A vitória dos Potiguaras é singular; a derrota dos Tabajaras só teve uma intenção: mostrar a parte oculta da "vitória" dos aliados, visto que tais índios acabaram junto com os negros, na senzala.

A triste imagem do índio na senzala é o resultado da aliança de Tabira com os portugueses. Mas os primitivos habitantes do Lácio também sucumbem ao poderio da conquista e fixação de Roma ${ }^{99}$. Porque, ao chegar ao Lácio, Eneias fez alianças com as tribos. Enquanto o seu nome penetrava poderoso no Lácio, o dos nativos sucumbia ${ }^{100}$. Eneias por fim, parecia ter compreendido o significado das alianças com os inimigos

\footnotetext{
98 Sodré 1969276.

${ }^{99}$ Parry1966 60.

${ }^{100}$ Wiesen 1973741.
} 
A hospitalidade é uma convenção natural nos poemas épicos. O rei Alcínoo é o exemplo típico de hospitalidade dos reis das cidades jónicas. Ao chegarem ao Lácio:

The newcomers are welcomed by the Latin king, and we learn that oracles have foretold the coming of a stranger from abroad who is to marry the king's daughter and become the ancestor and founder of a great nation ${ }^{101}$.

Entre os índios, o sentimento de hospitalidade era muito forte, considerando o hóspede como pessoa sagrada a quem destinam todas as pequenas comodidades da taba ${ }^{102}$. Mas os latinos e os indígenas tornaram-se vítimas desta hospitalidade; antes disso, tornaram-se vítimas das suas próprias crenças. Os oráculos latinos previram a chegada de um estrangeiro que se assentaria sobre o trono; já as armas capazes de produzir estrondos semelhantes aos temíveis trovóes e as embarcaçóes que vinham pelo mar provocaram uma espécie de temor nos indígenas, entre outros factores, e tais acontecimentos fi eram deles vítimas da sua própria recepção.

No poema Visóes, num discurso entre "O Índio" e "O Cantor", Gonçalves tentou reproduzir, ainda que timidamente, os dois pontos de vista: o do primitivo habitante e o do colonizador. Haveríamos de perceber a falta de conotaçáo entre os dois olhares:

Não somos nós irmãos - a tua pátria

Não é a pátria minha? Ali na marcada

Não tinhas outra vida - outro futuro? $(V 46-48)$

A resposta do Índio surge breve para o Cantor:

És dos grandes também - tu que assim falas.

Desses que aos Índios tem no rol de escravos?

Irônico sorrindo me inquiria $(V 49-51)$

Mas o Cantor não possuía escravos, tinha a mente livre, possuía o passo livre na terra. No final da visão, seguem-se apenas

${ }^{101}$ Camps 196913.

${ }^{102}$ Costa 1934 252. A taba é o nome que se dá ao tipo de habitação indígena. Trata-se de um conjunto de habitaçôes colectivas, denominadas ocas «oka». Normalmente dispostas ao redor de uma praça central «okara», ao redor da taba havia uma cerca de troncos para protegê-la. «Em português usa-se tanto o termo taba como aldeia para descrever o tipo de habitação indígena». 
as palavras do índio, convidando o Cantor para se sentar a sós com ele e ouvir histórias acerca dos tempos antigos, quando a Tribo Tupi era cheia de cantores. Histórias acerca dos detalhes que trouxeram a ruína, a morte e a destruição e acerca da "fuga do vencido sem combate!..." (V 76).

A escravidão que os portugueses trouxeram sobre as tribos era uma guerra sem combate, que vencia os índios, porque estes morriam na recusa de trabalhar. Não era o tipo de morte desejada, porém melhor seria morrer do que submeter-se aos trabalhos forçados.

Foi meu pai dos Tupis - último chefe,

E quando o búzio atroador soprava,

Três mil guerreiros corriam prestes

Ao guerreiro festim! (V 87-90)

Semelhantes aos poemas épicos gregos, quando os heróis consultavam o oráculo antes de qualquer batalha, os guerreiros Tupis consultaram os Piagas, acerca dos males que lhes vaticinavam. A conjectura táo pessimista dos acontecimentos extraordinários e sobrenaturais, do rouco estrondo desconhecido que vinha do ocaso, do ribombo que fez tremer os pés na terra, não deu ao poeta uma hipótese de optimismo. A questão diante dos Piagas era acerca dos males que estavam por vir, como se só houvesse esta hipótese, restando ainda a dúvida: "Que mal é?" Um dos anciãos ao som do maracá cantando, lançando raio para todas as direcçóes para onde olhava, figurando o trovão na voz trovejante, diz:

Treme - ó povo Tupi - Já não és povo

Eleito de Tupã,

Sumiu-se o teu poder como uma somba

No luzir da manhã (V 110-113)

A ruína dos Tupis sucederia, por virtude do abandono do culto ao deus Tupã, pela substituição deste culto por outro, e por isso seriam abandonados à sorte. $\mathrm{O}$ futuro da naçáo seria gemer e lembrar o povo que foi. $O$ poema encerra-se com a consciencialização do Índio: "Adeus, Cantor - adeus! Que a minha pátria não é a tua, não” (V 138-139). O poema Visóes, embora tenha sido um dos primeiros poemas a ser escritos, talvez devido ao espírito crítico do poeta só foi publicado depois da sua 
morte ${ }^{103}$. Para além da singeleza deste poema, está a magnificência das obras publicadas enquanto o poeta vivia.

$\mathrm{Na}$ corrente dos maus presságios da aliança do índio com o português, figur -se ainda o poema $O$ Gigante de Pedra, que segundo Coutinho ${ }^{104}$ poderia eventualmente ter algum parentesco com a figura camoniana do monstro Adamastor. Embora se saiba que Gonçalves reagiu ao modelo de Camóes, embora tenha repudiado a mitologia grega ${ }^{105}$, observamos que ainda assim o poeta se prendeu, sem dúvida, aos modelos das épicas gregas, latinas e até mesmo aos de Camóes.

Para Cristóvão ${ }^{106}$, o poema dá o mote imaginando o Brasil como um gigante adormecido a recordar a sua história, desde que viu os primeiros íncolas, robustos, das flo estas, batendo os arcos rígidos, e assistiu à chegada dos portugueses que depois expulsaram os estrangeiros posteriores à sua chegada, e também foi sendo testemunho de grandes mudanças. Mas a imagem optimista do Brasil como gigante adormecido esconde assim uma ideia pessimista, porque, enquanto a terra dormia, a sua gente primitiva era derrotada por invasores:

E no féretro de montes

Inconcusso, imóvel, fito

Escurece os horizontes

$\mathrm{O}$ gigante de granito.

Com soberba indiferença

Sente extinta a antiga crença

Dos Tamoios, dos Pajés;

Nem vê que duras desgraças,

Que lutas de novas raças

Se lhe atropelam aos pés! (GP 83-93)

O gigante assiste a tudo imóvel, vê a gente primitiva espalharse pelas matas ínvias à procura da sobrevivência, fugindo ao vil invasor. Se, por um lado, o gigante camoniano, Adamastor, afundava as naus e incutia medo aos navegantes que se interpusessem no seu caminho, o gigante de pedra gonçalvino estava adormecido. Porém, ambos têm algo em comum, o pessimismo que representam; porque, no caso de Adamastor, o

${ }^{103}$ Datado de 25 de Dezembro de 1844, na cidade de Pitóes.

${ }^{104}$ Coutinho 198691.

105 Coutinho 198691.

${ }^{106}$ Cristóvão 2004 13-14. 
gigante trazia o sofrimento e o temor entre os marinheiros que se viam obrigados a passar por aquele caminho; já o gigante gonçalvino manteve-se intransigente diante das mudanças a seus pés, embora a crença do poeta permanecesse:

Porém se algum dia fortuna inconstante

Puder-nos a crença e a pátria acabar,

Arroja-te às ondas, o duro gigante,

Inunda estes montes, desloca este mar! (GP 143-146)

Os primeiros íncolas não tiveram tal sorte, perderam a pátria e a crença; deixaram de existir, enquanto o gigante permaneceu adormecido. Viviam numa pátria perfeita, certamente ideal, porque chegam a sucumbir por não poderem submeter-se a outro estilo de vida. No início do sétimo livro da Eneida, Virgílio também mostra que os latinos viviam numa civilização perfeita e certamente idealizada. Para Farron ${ }^{107}$, isso prejudicava a imagem de que os romanos e latinos se juntaram para construir a paz futura. O próprio confronto entre estas raças demonstrava como seria construída esta paz romana. Desta maneira, a poética de Santa Rita Durão e de Basílio da Gama também fica comprometida; porque nelas, o primitivo e o colonizador unem-se para fundação do Brasil; mas a uniáo de Diogo com Paraguaçu demonstra como seria construída esta nação.

Depois de nos confrontarmos com o optimismo e o pessimismo nos poemas que narram a união entre o índio e o português, bem como no retrato da uniáo que trouxe a morte e a extinção dos primitivos habitantes, confrontar-nos-emos com as transformaçôes causadas aos índios que se misturaram com os portugueses na fundação de uma nova raça, de um povo mestiço.

$O$ Canto do Índio talvez seja o mais complexo, porque é singular entre os poemas indianistas de Gonçalves Dias. A configuração deste poema segue a premissa de Santa Rita Durão e de Basílio da Gama. O poema estrutura-se à semelhança de uma cantiga de amor do lirismo galego-português medieval ${ }^{108}$. Os atributos da mulher amada que aqui provocam encantamento no índio são próprios de uma europeia e são os mesmos que em Marabá eram rejeitados pelos guerreiros nativos ${ }^{109}$.

${ }^{107}$ Farron 1982140.

${ }^{108}$ Oliveira 200547.

${ }^{109}$ Oliveira 200549. 
Nas obras árcades de Basílio da Gama e Santa Rita Durão, os indígenas desempenham um papel secundário e de subserviência ao colonizador luso. Outro traço original da poesia de Gonçalves Dias está na concessão de uma "voz poética" própria do índio, tendo em vista que o mesmo, por náo ter sido contaminado pelos males da civilização, é simbolicamente superior ao europeu ${ }^{110}$.

Embora o índio de $O$ Canto do Índio tenha uma tendência para a subserviência semelhante aos índios das obras supracitadas, existem diferenças no processo que implica a sua realização, porque nenhum destes autores manifestou o interesse de construir uma poesia nova ou americana. Além disso, estes índios surgem na condição de bárbaros inferiores à civilização europeia ${ }^{111}$. O índio gonçalvino, mesmo quando assume as convençóes de subserviência dos nossos árcades, tal como sucede em $O$ Canto do Índio, ainda assim é partede um novo ponto de vista e de uma nova visão indígena. De acordo com Roncari ${ }^{112}$, a perspectiva do índio se faz necessária, já que ética e culturalmente estariam mais aptos a julgar os europeus do que estes a eles.

$\mathrm{O}$ amor do índio nasce exactamente nas mesmas convençóes que regiam os poemas do medievalismo europeu; talvez Gonçalves quisesse mostrar que o índio era capaz de ser atraído por uma mulher no banho, semelhante ao que acontecia com os cantores europeus. Isto poderia ser visto como um processo de legitimação dos sentimentos indígenas, tendo em vista que este poema está entre os primeiros que Gonçalves escrevera. Para Roncari ${ }^{113}$, o índio gonçalvino, ao falar, procura por outro ponto de vista reflectir sobre o mundo social que o cerca, sem se apoiar em preconceitos ou em idealizaçóes puramente literárias.

Ao cantar a mulher amada, o índio faz comparaçóes com elementos da natureza ${ }^{114}$ : ela é "bela como a fonte cristalina como a luz de meiga estrela" (CI 6-8); quando sorri, é mais bela "que a aurora quando ao raiar principia" (CI 33-34); por fim,

Bem como gotas de orvalho

Das folhas de flor mimosa

Do seu corpo a onda sem fio

Se deslizava amorosa. (CI 48-52).

${ }^{110}$ Marques 2006180.

${ }^{111}$ Roncari 1995377.

112 Roncari 1995377.

${ }^{113}$ Roncari 1995381.

${ }^{114}$ Oliveira 200549. 
Mas o amor do Índio torna-se semelhante ao amor de Dido por Eneias e de Turno por Lavínia. Para Putnam ${ }^{115}$ :

The diffe ence lies in the two sides of the simile. Turnus, because of his love for Lavinia, is suffering a wound similar to Dido's in the opening lines of IV, and passion inevitably rules his judgment in some of the decisions which follow.

Em virtude do amor inevitável, Dido sucumbe à morte, ao ver-se abandonada por Eneias; as decisóes de Turno estão de facto condicionadas pela sua paixão por Lavínia. Dido e Turno tornamse vítimas de Eneias e consequentemente do papel civilizador da nação romana.

Por detrás do optimismo está o pessimismo; por detrás do amor que traz a vida está a guerra que traz a morte. Por um lado, o sentimento de fidelidade de Tabira iguala-se ao sentimento de amor do Índio. Ambos sucumbem à instalação da nova civilização. No encerramento do poema, ainda em favor do seu amor, o Índio diz ser capaz de relegar o seu dever de guerreiro; desdenhando do canto de guerra de seus companheiros e abrindo mão do seu poder, entregando-se como escravo aos europeus, uma vez que, pela mulher amada, venceria o ódio antigo ${ }^{116}$.

Mas queiras tu ser minha, que eu prometo
Vencer por teu amor meu ódio antigo,
Trocar a maça do poder por ferros
E ser, por te gozar, escravo deles. (CI 56-59)

Esse é um evento singular na poesia gonçalvina. Em nenhum outro momento se vê o índio aceitando a escravidão. Até mesmo nas cartas dos Jesuítas que apesar de declararem a humanidade do índio, reconheciam neles também a bestialidade ${ }^{117}$; os Jesuítas depararam com índios que queriam e desejavam ser cristãos; mas deixar os seus costumes parecia-lhes demasiado áspero ${ }^{118}$. $O$ Canto do Índio traiu todas as convençóes indianistas de Gonçalves Dias, porque o Índio atraído pela europeia quer sacrificar os mais nobres dos seus sentimentos.

115 Putnam 1988156.

116 Oliveira 200550.

117 Silva Dias 1982224.

118 Silva Dias 1982227. 
O Canto do Índio contradiz totalmente todas as convençóes indianistas de Gonçalves Dias, mas o que tende a ser uma contradição torna-se também uma inovação literária; porque em nenhum momento anterior, algum poeta ou escritor registou o amor do índio pela europeia, apenas o da índia pelo europeu, tal como fi era Santa Rita Duráo com o amor entre Caramuru e Catarina Paraguaçu, que confirma a tendência inicial da carta de Caminha. Esta disposição gonçalvina firmaria o seu contrato nas obras de José de Alencar.

Ackermann ${ }^{119}$ também nos chama a atenção para a contradição entre $O$ Canto do Índio e Marabá, porque todos os elementos de admiração no primeiro poema são as causas do sofrimento da índia mestiça. O poema Marabá estrutura-se à semelhança de uma cantiga de amigo de tradição galego-portuguesa medieval, apresentando uma voz lírica feminina que canta os seus infortúnios amorosos ${ }^{120}$. A frase inaugural do poema já revela $\mathrm{o}$ carácter pessimista desta obra:

Eu vivo sozinha, ninguém me procura! (M 1)

Ao contrário do Índio que sofre por amor, Marabá sofre pela falta deste, pela falta de pretendente. Segundo Oliveira ${ }^{121}$, o poema é composto por quatro períodos de lamentos: no primeiro, Marabá não vê a quem dirigir as suas palavras amorosas; no segundo, ela lamenta náo poder enfeitar a fronte de nenhum homem com ramo de acácia; no terceiro, diz que nunca será desprendida de sua arasóia (arasóia, segundo os cronistas do século XVI, era uma espécie de saiote de plumas utilizado pelas índias, indicando que ainda eram virgens); e no quarto, deixa viva a percepção de que a raiz de todos seus males está na sua condição de mestiça.

Eu vivo sozinha, ninguém me procura!

Acaso feitura

Náo sou de Tupá?!

Se algum dentre os homens de mim não se esconde:

— "Tu és", me responde,

“Tu és Marabá!”(M 1-6)

119 Ackermann 196497.

${ }^{120}$ Oliveira 200541.

${ }^{121}$ Oliveira 200545. 
Marabá sente-se como se não fosse uma criatura de Tupã. Aquilo que deveria tornar-se um canto de felicidade, ou de esperança, como é o caso de O Canto do Índio, torna-se o canto de tristeza, de desespero, da falta de esperança. Marabá lamenta não encontrar entre a sua tribo um pretendente, e afirma que aqueles que dela não escondiam o rosto respondiam: "Tu és Marabá!"

Os poucos pretendentes que aparecem, também são marabás: possuem olhos esverdeados, mas os olhos almejados pela mestiça são os olhos bem pretos, fulgentes. Apesar disso, ela reconhece a cor de seus olhos: da cor de safira, olhos garços, que imitavam as nuvens em céu anilado, e as cores imitavam as vagas do mar.

As imagens fornecidas no decorrer do poema retratam os motivos da tristeza e do pessimismo de Marabá. O rosto semelhante à alvura dos lírios produz um contraste dentro da obra gonçalvina, que só encontramos na sua obra. A cor da morte e do sofrimento em Gonçalves tem valores ímpares, porque ela se apresenta como a cor da paz, o branco. Já o preto e o vermelho, tradicionais cores da morte e do sofrimento, significam a cor da felicidade e da vida. O contraste de Gonçalves é propositado, está na própria intenção poética. A inversão de valores entre o índio e o europeu, a que faz a poética de Gonçalves, também é a inversão da simbologia entre os mesmos.

O sofrimento de Marabá está na cor de sua pele, semelhante às areias batidas do mar, às aves mais brancas, às conchas mais puras, enquanto os índios preferiam as mulheres com o rosto de jambo corado, crestado ao sol do deserto. Na poética de Gonçalves, o vermelho tem apenas um significado, o da vida; a possibilidade da continuidade da raça. A mulher semelhante à flor de cajá significa a a extinção de raça e, ao mesmo tempo, o nascimento de outra. Por isso, Marabá derrama os seus lamentos, porque os seus loiros cabelos ondulados, semelhantes ao ouro mais puro, não atraíam pretendentes, que preferiam os cabelos pretos e lisos, corridos, compridos.

Marabá é o exemplo do nascimento desta nova raça. O caso do Índio que se apaixona pela europeia é ímpar, porque este evento praticamente não acontecia, principalmente nos primeiros anos, quando a imigração era essencialmente masculina. Porém, o que vale na poética gonçalvina é a verdade poética e não a verdade histórica; e Gonçalves soube muito bem utilizar-se da verdade histórica, quando julgou que ela prevalecia. O caso de Marabá, por exemplo, tornara-se uma rotina no seio da terra dos índios. 
De acordo com Kothe ${ }^{122}$, Marabá demonstra como se realizou a miscigenaçáo: de um lado o colonizador europeu e do outro o elemento indígena feminino, não havendo uma alteração no português, mas no nativo. Tal também sucedera aos Latinos; para Putnam $^{123}$, Eneias impóe Tróia na Itália, enquanto membro da última geração de Troianos, mas configur -se como a primeira raça de romanos. A diferença está entre a ruína de Tróia e a expansão portuguesa; porque Eneias náo possui uma pátria e por isso é forçado a ser parte da última geração de Troianos, e em nome da continuidade da vida, é forçado a unir-se aos latinos na formação de uma nova raça. Obviamente que a perda da identidade é a causa do sofrimento de Eneias, mas ele vence a perda pela conquista da nova identidade, teoricamente superior à que fora perdida.

Também de acordo com Fernandes ${ }^{124}$, o retrato de Marabá expressa o surgimento de uma nova raça, a mestiçagem. De acordo com a ordem social dos Tupinambás, a expectativa do casamento era com uma mulher desflorada. O desfloramento ocorria quando a rapariga era considerada uma kugnatim, logo depois das regras e dos ritos da puberdade. Entretanto, ela apenas se casava quando pertencia à categoria das kugnammuçus. Ainda que este desfloramento viesse a acontecer em oculto, a moça deveria indicá-lo, rompendo os fios de algodáo amarrados na cintura e nos braços, de modo que o facto fosse do conhecimento público. Apesar dessa associação mágica, os tupinambás davam pouco valor às ocorrências. Não lhes faltariam pretendentes. Em determinas ocasióes, os pais recebiam recompensa, cedendo-as a qualquer varão. A mestiçagem encontrou nesse campo fértil o instrumento de que precisava para acontecer, uma vez que os pais entregavam as filhas a troco de quinquilharias e ninharias dos europeus.

É uma pena que Gonçalves, ao trabalhar a questão da mestiçagem, trate apenas entre o índio e o branco, e jamais com o negro. Obviamente que o poeta vivera numa época escravocrata, mas isto não o exime de abandonar o negro, referindo-o muito pouco na sua obra. A posiçáo do negro era de tão baixa reputação que Sodré observa que a seis de agosto de mil e setecentos e setenta e um, o vice-rei do Brasil

\footnotetext{
122 Kothe 1997223.

${ }^{123}$ Putnam 1988152.

${ }^{124}$ Fernandes 1989139.
} 
baixou uma portaria, dando baixa do posto de capitão-mor a um índio, porque se mostrara de tão baixos sentimentos que se casou com uma preta, manchando o seu sangue com esta aliança, e tornando-se assim indigno de exercer tal posto $^{125}$. Por outro lado, a união entre índios e europeus era amplamente permitida, como também incentivada durante o colonialismo, embora os nomes de pessoas jamais devessem ser caboclos ${ }^{126}$; Marabá, portanto, torna-se o símbolo dessa premissa portuguesa. Isso impossibilita o optimismo dentro da poesia gonçalvina.

O poema encerra-se com as lágrimas em face do desespero:

E as doces palavras que eu tinha cá dentro

A quem nas direi?

O ramo d'acácia na fronte de um homem!

Jamais cingirei:

Jamais um guerreiro da minha arazóia

Me desprenderá:

Eu vivo sozinha, chorando mesquinha,

Que sou Marabá! (M 47-54)

Para Ackermann ${ }^{127}$, é possível que Marabá também seja o canto de Gonçalves em face dos sofrimentos que a mestiçagem lhe causou. Enquanto Marabá sofre no seio de sua tribo, por não encontrar entre eles um pretendente de sangue puro, Gonçalves também amarga esta perda no seio de sua gente, pela falta de pureza consanguínea, também de pureza de raça.

É possível que a falta de esperança de Marabá seja o refle o da falta que o poeta possuía; num dos seus poemas mais desesperados e mais belos, Gonçalves encerraria o poema com a mesma desesperança, com a mesma desventura, com o mesmo pessimismo:

Lerás porém algum dia

Meus versos, d'alma arrancados,

D'amargo pranto banhados,

Com sangue escritos; - e entáo

Confio que te com vas,

${ }^{125}$ Sodré 1969276.

${ }^{126}$ Sodré 1969276.

127 Ackermann 196496. 
Que a minha dor te apiede,

Que chores, não de saudade,

Nem de amor, - de compaixão ${ }^{128}$.

A compaixão que o poeta pede à mulher amada é a mesma que Marabá espera do leitor, porque ambos nada podiam fazer, porque o mal estava feito. A interferência de estranhos é o motivo das dores de ambos, no caso de Gonçalves "os feros coraçóes" que se meteram entre ambos e venceram. Marabá era o fruto da invasão, da corrupçáo de raças. Paulatinamente os índios estavam sendo vencidos, à semelhança dos índios de Tabira e da Tribo dos Tupis de Visóes, porque, em ambos os casos, a derrota era sem combate.

Marabá é o único canto gonçalvino de uma heroína indígena ${ }^{129}$. O que deveria ser um canto de felicidade tornou-se um canto de desespero. Os portugueses trouxeram uma felicidade aparente para as tribos, mas o projecto de civilização consistia na extinção dessa raça. Antes de conhecerem os europeus, os índios usavam ferramentas e instrumentos de pedras, ossos, paus, canas, dentes de animais, etc. Cardim ${ }^{130}$ demonstra surpreender-se com a destruição de grandes matos com cunha de pedra, embora fossem ajudados pelo fogo, além dos arcos e flechas que eram tão bem feitos. Com o conhecimento do ferro, toda a actividade indígena passou a executar-se em menos tempo e com maior facilidade, razão pela qual folgavam com a comunicação com os brancos.

Esta aparente folga de que fala Cardim está comprometida com o projecto da civilização portuguesa. Os queixumes de Marabá são indícios de que os índios nunca sentiram uma felicidade serena com a chegada destes estranhos. As trocas de favores comprometiam-se ao longo dos tempos, e não tardou que o índio conhecesse no português o espírito insaciável. Na epopeia virgiliana, desde a chegada de Eneias, em nenhum momento Dido sente uma felicidade serena ${ }^{131}$. Porque, tanto no caso dos índios quanto de Dido, ambos sentem-se presos ao interesse e dependem dele, mas dali virá a sua ruína e a sua morte.

Tróia caiu, ergueu-se Roma. Como aconteceu com Lavínia, também esta recebeu um sinal semelhante, igualmente de duplo alcance: para ela o destino traçava um grande futuro - ser mãe

${ }^{128}$ XVIII estrofe de Ainda uma vez - Adeus.

${ }^{129}$ Moisés 198937.

${ }^{130}$ Cardim 1939157.

${ }^{131}$ V. Pereira 199292. 
de uma nova civilização que haveria de dominar o mundo ${ }^{132}$. Tais poderiam ser as convençôes de Marabá: o símbolo do surgimento de uma nova raça, a dos mestiços; enquanto em Visóes o Piaga afirma

Mas um dia virá, bem longe d'hoje,

E os teus livres serấo;

Mas esse dia - não verás, ó povo,

Teus filhos - também não! V 130-133)

A extinção da raça indígena estava condicionada ao surgimento dessa nova raça ${ }^{133}$, a raça que um dia também haveria de tornar-se livre; é óbvio que o poeta queria referir-se ao evento $\mathrm{da}$ independência brasileira. Marabá prefiguraria, portanto, o símbolo glorioso do início dessa raça. Mas, ao contrário de Lavínia que desperta o amor do recém-chegado e do primitivo habitante, Marabá não encontra pretendentes entre os seus, e esta é a razão do seu sofrimento. Sente-se como se não pertencesse à sua raça. $\mathrm{O}$ sentimento que Turno dispensa a Lavínia faz dela uma latina. Já o sentimento de Eneias significa a a possibilidade de tornar-se mãe de uma nova civilização. A heroína tem de escolher entre ambos, mas, ao escolher o futuro, não se sente despojada da sua origem. Talvez seja por esta razão que Marabá tanto hesita em encontrar, entre os seus semelhantes, um pretendente; a heroína pretende primeiro firma -se como herdeira da raça primitiva. Entretanto, ao contrário de Lavínia, Marabá já era fruto da mestiçagem, portanto deixou de ser índia, e também não pertence à raça dos lusos.

Enfim, por detrás da união entre o índio e o europeu estava a morte; a felicidade aparente em virtude da troca de favores não traduzia o horror que nela estava impregnado. Porque, no final, os indígenas vitoriosos nas batalhas acabavam escravos, as suas mulheres eram tomadas, os seus filhos reduzidos ao cativeiro, e a sua geração extinta, transformada pela mestiçagem e pela união violenta do europeu com o índio. A morte gloriosa de Tabira configur -se com uma figura nostálgica de um passado honroso para sua tribo - um passado que o Índio de $O$ Canto do Índio sente necessidade de abandonar; um passado que já não pertence

${ }^{132}$ André 199252.

${ }^{133}$ A Eneida canta o surgimento de um povo a partir da morte das cinzas de outro povo, e André discorre quão alto era o preço da fundação de uma nova raça. André 199247. 
a Marabá; e de que o Índio, em Visóes, sente saudades quando, ao som do búzio atroador, três mil soldados corriam para a batalha. 


\section{Guerreiros: retratos de uma civilizaçáo perdida}

"Pobre íncola! Por que não descobriste a pólvora antes do chinês?" Lima Figueiredo

O tema essencial da história da formação de um elemento indígena é a guerra. As tribos viviam em função das batalhas e esta organização remonta aos tempos mais antigos. A facilidade com que se encontravam para fazer alianças com os índios contrasta com a facilidade que tinham em torná-los inimigos. Por qualquer motivo que seja, desde os mais simples, a ofensa tornava-se imperdoável, sendo esta ira transmitida de geração a geração. E não se dão por perdoados enquanto um dos lados não for destruído.

A virtude de um guerreiro náo estava na quantidade de guerreiros que conseguia matar. As palavras de Tabira cristalizam a honra que resulta de matar apenas um guerreiro: “- Basta, vis, por vencer-vos um só!” (T 176). A força e a destreza guerreira e acima de tudo o heroísmo atingiam o clímax numa morte honrosa. As palavras de Tabira, quando aparece ao final do poema, cravejado de muitas setas, semelhante à imagem de um porco-espinho, quebrando setas que impediam os passos, de rosto banhado de sangue, arrancando sem dó uma flecha com o olho espetado e mostrando-o aos seus assassinos como se fosse um troféu de honra ao mérito, incitam ainda mais a ira nos inimigos. É a evocação de um herói homérico junto às muralhas de Tróia.

Porém, se a morte no campo de batalha é motivo de honra, semelhante à de Tabira, por outro lado, morrer num banquete antropofágico é motivo ainda de honra maior: o prisioneiro não se demonstrava intimidado diante de um acto repugnado pela cultura ocidental. Quando cantava os seus feitos de morte, dizia ao matador que os que ali estavam náo iriam comer a sua carne, $\mathrm{e}$ sim a carne de seus parentes, porque havia comido os pais, entre muitos outros membros daquela tribo; estava ali para ser morto e comido, mas os seus parentes e amigos haveriam de vingar a sua morte. 
Assim, baseado numa sociedade guerreira, Gonçalves tenta extrair a maior pureza dos costumes indígenas, a fim de reconstruir, por intermédio de uma pragmática poética, o que as convençóes históricas repeliram e compeliram para o esquecimento. Para isto examinaremos alguns poemas que tratam deste tema.

$O$ Canto do Guerreiro, portanto, pertence a uma dimensão poética que trata com optimismo os feitos do índio, mas convém dizer que por detrás desse aparente optimismo que Gonçalves atribuiu a este poema - observe-se que é o único dentre a sua obra indianista que não trata explicitamente a destruição a que os índios se submeteram por causa da chegada dos europeus - há um pessimismo no próprio cântico.

$O$ Canto do Guerreiro canta os feitos e a bravura de um combatente indígena; de todas as honras e gostos da vida, nenhuma era maior para os índios do que matar e tomar nomes nas cabeças de seus inimigos ${ }^{134}$. O poeta estabelece um diálogo entre o chefe indígena e a sua tribo, onde apenas um interlocutor dirige o seu canto e suas indagaçóes; ao mesmo tempo, o convite do chefe indígena aos seus guerreiros para ouvir o seu cantar é também a forma como o poeta incita o seu leitor a ouvir o cântico do bravo guerreiro.

$\mathrm{Na}$ primeira estrofe, o poeta abre um cenário de uma selva intocada pelos colonizadores. As primeiras palavras são direccionadas por um interlocutor que não é o guerreiro, como se fossem uma informaçáo ao leitor quanto ao local e o que se há-de cantar: na selva intocada pelos colonizadores, façanhas de bravos náo geravam escravos, que valorizavam a vida sem guerra nem lide. Então surge o guerreiro que conclama:

_ Ouvi-me, Guerreiros.

_ Ouvi meu cantar. (CG 7-8)

$\mathrm{O}$ soldado começa a dirigir palavras que se assemelham em muito às características de Tabira - o chefe e soldado valente, que cumpria o tratado mais do que ninguém, que náo se aterrorizava diante dos perigos, que corria aos acenos da guerra mais do que ninguém. Assim o Guerreiro também celebra a sua valentia acima de todos os homens.

Valente na guerra

Quem há como eu sou?

${ }^{134}$ Cardim 1939 159; Costa 1934261. 
Quem vibra o tacape

Com mais valentia?

Quem golpe daria

Fatais, como eu dou? (CG 9-14)

Nos poemas épicos de Gonçalves, percebe-se a grande presença dos costumes dos guerreiros embrutecidos; na sociedade indígena a sobrevivência de um guerreiro era alimentada pela honra e fazia parte do ritual da vida. À semelhança da cultura homérica ${ }^{135}$, o indígena gonçalvino adquire consciência do seu valor pelo reconhecimento da sociedade a que pertence. Mas para ganhar este reconhecimento era necessário tornar-se um guerreiro valente. Ser o melhor era imprescindível, porque os melhores sobreviviam e tornavam-se comandantes nas guerras e chefes das tribos.

O Guerreiro continua a cantar os seus feitos de guerra. Ninguém melhor que ele guiava a flecha emplumada na direcção correcta; tinha capturado mais inimigos que todos; e indaga quem com mais energia cantava os seus feitos. Depois de cantar os seus feitos de guerra, o Guerreiro canta a sua destreza na caça:

\author{
A onça raivosa \\ Meus passos conhece, \\ $\mathrm{O}$ imigo estremece, \\ $\mathrm{E}$ a ave medrosa \\ Se esconde no céu. (CG 35-39)
}

Em sequência, o Guerreiro afirma que quando reboa as matas com os sons do Boré, mil arcos se encurvam, mil setas voam, mil gritos retumbam, mil homens de pé. O Guerreiro tinha mil soldados à sua disposição, e eram todos valentes guerreiros, prontos a atender o seu pedido numa guerra e, depois de encurvarem os seus arcos, dispararem suas setas e gritarem de pé como soldados. A destreza com que descreve os seus guerreiros é típica do estilo gonçalvino:
Lá vão pelas matas;
Não fazem ruído:
$\mathrm{O}$ vento gemendo
$\mathrm{E}$ as matas tremendo
E o triste carpido

${ }^{135}$ Jaeger 199531. 
Duma ave a cantar,

São eles - guerreiros,

Que faço avançar. (CG 53-59)

Eis uma face pessimista do poema: os ventos não gemem; as matas não tremem no sentido indicado e as aves não possuem pranto lastimoso. Mas o poeta fez o vento gemer, como quem derramava lamentos; as matas tremeram como quem é movimentado convulsivamente pelo vento lamentoso; e o cântico de uma ave torna-se um triste carpido. O poeta poderia ter simplificado o canto melancólico da ave solitária, porque o cântico dela é triste. $\mathrm{Na}$ afirmação "triste carpido", o termo triste por si só inspira a melancolia do canto da ave, mas o poeta reforça a tristeza, o triste carpido, como o triste barulho de uma ave, o triste pranto lastimoso.

$\mathrm{O}$ poeta abre uma lacuna. Por que gemia o vento? Por que tremia a mata? Por que soava tão melancólico o canto de uma ave? Enquanto soava a melodia deprimente da ave, o seu exército avançava por entre a mata que se movimentava pelos soluços do vento.

Embora se possa conceber a ideia de que os índios não tinham fronteiras políticas, semelhante aos países europeus daquela época, no entanto, os índios estabeleciam fronteiras com vários grupos tribais, com os quais viviam continuamente em guerra ${ }^{136}$. A partir disto podemos perceber por que razão a guerra possuía um carácter notório. A guerra dizia da tribo, do domínio e da sua extensão. $\mathrm{O}$ Guerreiro canta o seu exército e a sua força. $\mathrm{O}$ seu exército era composto de mil guerreiros que deixavam os campos juncados de mortos, no entanto nenhuma alma dentre os seus se perdia:

Mil homens viveram,

Mil homens são lá. (CG 66-67)

Para consolidar os pressupostos macambúzios do poema - que descreve o canto triste da ave, a mata que tremia pelo movimento causado por um vento queixoso, como sinal de tristeza pela morte que pairava no ar, os ares flechados que deixavam os campos juncados de mortos, como quem expressa as dores dos inimigos do Guerreiro - o poeta decide encerrar sua obra épica com a força imperatriz da melancolia:

${ }^{136}$ Fernandes 198926. 
E entáo se de novo

Eu toco o Boré;

Qual fonte que salta

Da rocha empinada,

Que vai marulhosa,

Fremente e queixosa,

Que a raiva apagada

De todo não é,

Tal eles se escoam

Aos sons do Boré.

_ Guerreiros, dizei-me,

_ Tão forte quem é? (CG 68-79)

O Guerreiro compara o seu exército a uma fonte que salta da rocha, vibrando por um entusiasmo de descontentamento. Porque, por mais que tivessem vencido a batalha sem que perecesse uma só alma entre eles, e deixando assim o campo juncado de mortos, saem descontentes, porque a ira não está apagada. O que deveria ser um canto de celebração vitoriosa torna-se um canto lamentoso. Parte do optimismo de um exército nativo que só sabe vencer, - cujo cantor é o mais forte entre seus soldados - para o pessimismo, já que a vitória não é completa. A vingança não foi capaz de aniquilar a cólera.

Poderíamos estabelecer um paralelo entre o carácter antiépico de $O$ Canto do Guerreiro e a Eneida. Nas narrativas clássicas, os deuses prevêem os acontecimentos, mas eles também estão configurados em figuras de linguagens 'ocultas' dentro do texto: na Eneida, por exemplo, a tragédia de Dido é uma antecipação da morte de Turno ${ }^{137}$. Assim, a expressão melancólica da natureza anunciada na estrofe VII, quando o exército do Guerreiro se retirava para a batalha, era a antecipação da melancolia da última estrofe, quando seu exército se retiraria vitorioso, porém queixoso dos campos de batalha - como quem vence o inimigo, mas não é capaz de espantar de dentro de si a cólera que ele causou.

Se, em $O$ Canto do Guerreiro, o poeta quis celebrar a glória dos feitos de uma tribo e o poema acaba por encerrar-se com uma vitória insatisfeita e melancólica, em $A$ Canção do Tamoio, um canto natalício em que o poeta deveria apenas celebrar o nascimento de um guerreiro ideal, acabou por se tornar um canto de lágrimas e sofrimentos. Ora, o nascimento é tido como

137 Williams 19834. 
o princípio para a fase áurea da vida humana. Primeiro porque é o início de uma vida, segundo porque adquire as dimensóes de conservaçáo da raça. Mas aquilo que deveria ser uma celebraçáo de vida e felicidade torna-se um poema de infelicidade e lágrimas, a começar pelos primeiros cantos:

Não chores, meu filho

Não chores, que a vida

É luta renhida:

Viver é lutar. (CT 1-4)

As palavras dirigidas ao guerreiro que acaba de nascer demonstram com que pessimismo é vista a vida nas Tabas. As lágrimas faziam parte nos rituais indígenas, quando tinham hóspedes choravam como quem sofre com aquele que sente saudades do seu rebento. As lágrimas podem ocupar duas categorias para o elemento indígena, as de repulsa e as de celebração, da honra ou da desonra. Isto está configurado no poema I-Juca Pirama: as lágrimas do prisioneiro diante da morte foram a causa da maldição do seu pai, porque elas envergonhavam e traziam a desonra sobre a tribo Tupi; já as lágrimas do velho Tupi, diante da bravura do filho que requer a honra que lhe é devida ao submeter-se ao ritual (conforme deveria ser), eram lágrimas de honra, de glória, de celebração.

Mas, em $A$ Canção do Tamoio, o "eu" lírico pede ao que nasce para que não chore, porque a vida é semelhante a um combate que aos fracos abate, mas que aos fortes e bravos só pode exaltar. O homem forte não teme a morte, só teme fugir. Estas palavras evocam novamente a semelhança com o guerreiro Tupi feito prisioneiro pelos Timbiras em I-Juca Pirama, porque o guerreiro, quando implora por sua vida, fá-lo porque tem medo que o pai o considere ingrato. Todavia receia que os Timbiras pensem que está a escapar-se da morte, e quando as palavras do chefe Timbira cristalizam a sua dúvida em realidade, o guerreiro Tupi desiste de partir, querendo retornar ao ritual.

No entanto, o poeta encontra um optimismo no sofrimento que a morte pode causar, o da honra:

Domina, se vive;

Se morre, descansa

Dos seus na lembrança,

$\mathrm{Na}$ voz do porvir. 
Não cures da vida!

Sê bravo, sê forte!

Não fujas da morte,

Que a morte há de vir! (CT 25-32)

Eis o optimismo: dominar enquanto viver; e quem morre descansa. O conselho para não fugir da morte, vem como uma esperança, porque a morte há-de vir. Portanto é melhor morrer com honra do que esperar a morte, e ao cabo disto, não findar como aquele que foi. Ou seja, para o índio náo basta viver. Morrer como viveu é essencial. A morte nos campos de batalha sempre significou morrer como um herói esforçado para as sociedades primitivas.

A reivindicação prossegue pelos cantos subsequentes, um guerreiro Tamoio devia ser valente, o suficiente para se abster da vida diante da situaçáo adversa que esta exigisse. Deveria representar a tribo na guerra ou na paz e o grito de guerra deveria retumbar nos ouvidos dos inimigos, pior que o silvo das setas ligeiras, pior que o trovão. $\mathrm{O}$ trovão, representando o poder de Tupá, era um dos elementos mais temíveis para o índio. Pelo que aí se percebe, o terror do trovão correspondia ao terror que o guerreiro ideal deveria causar nos inimigos. Proclamado nas tabas inimigas, o seu nome não setia ouvido sem causar prantos e dores.

Mas o poeta reconhece que os grandes também se abatem, e esta imagem podemos perceber no chefe dos Gamelas (Os Timbiras) e em Tabira. Segue-se então o conselho para o nobre guerreiro que cai diante do inimigo:

E cai como o tronco

Do raio tocado,

Partido, rojado

Por larga extensão;

Assim morre o forte!

No passo da morte

Triunfa, conquista

Mais alto brasão. (CT 65-72)

A morte de um guerreiro pode assumir duas dimensóes, primeiro semelhante às ervas do campo que vivem tapadas pelo sol e morrem facilmente quando expostas a ele; ou como a copa das árvores frondosas que são as primeiras a ser tocadas pelo poder consumidor dos raios, isto é, pelo poder de Tupá. Cabia 
ao guerreiro, diante da morte, escolher como queria morrer: de forma gloriosa, como Tabira, cravejado de setas, porém ainda capaz de afligir a ira no coraçáo dos inimigos; ou como aquele que chorou diante da morte, na presença dos Timbiras, e que teria morrido vergonhosamente se tivesse caído diante dos Aimorés, mas que por sorte do ritual Timbira, teve a oportunidade de se redimir alcançando a honra que ameaçou perder, triunfando com o mais alto brasão.

A Canção do Tamoio, de celebração do nascimento de um guerreiro ideal, possui um pessimismo, náo apenas porque o nascimento de um guerreiro indígena seja uma estilização nostálgica daquilo que não se deixa mais cantar, mas porque os conselhos de como ser um bom lidador estão carregados de sofrimento. Um dia vivemos e o homem que é forte não teme a morte (CT 9-11); não se anuncia a morte para quem acaba de nascer. Aliás, a morte é algo que passa longe diante do nascimento. Mas o poeta anuncia-a, num misto de felicidade e tristeza, de vida e morte. A felicidade está configurad no nascimento de um novo guerreiro, mas também a tristeza, pois a vida é como uma luta que aos fracos abate e aos fortes só pode exaltar. Não existe luta que não exija esforço. O esforço necessita da coragem; a coragem é a firm za de ânimo diante do perigo. Viver, para o índio, é, portanto, um constante perigo, do qual apenas se liberta pela morte (CT 32).

Se em $A$ Canção do Tamoio, a celebração do nascimento de um guerreiro ideal está configurada numa esperança melancólica, e em $O$ Canto do Guerreiro, o poeta quis celebrar a glória dos feitos de uma tribo, encerrando-se numa vitória insatisfeita e sorumbática, em $O$ Canto do Piaga a merencória ocupa as três partes que compóem o poema. Se em $O$ Canto do Guerreiro, ainda havia o fio de esperança numa guerra honrosa, e em $A$ Canção do Tamoio, ainda havia uma esperança de honra para aqueles que morrem como heróis esforçados, O Canto do Piaga, por sua vez é completamente apocalíptico, porque narra apenas ruína, desgraças e destruições que sobreviriam sobre os indígenas.

Na primeira parte do poema, o "eu" lírico, personificado num Piaga, conclama os guerreiros para ouvirem seu canto:

Ó Guerreiros da Taba sagrada,

Ó Guerreiros da Tribu Tupi,

Falam Deuses nos cantos do Piaga,

Ó Guerreiros, meus cantos ouvi. (CP 1-4) 
Os Piagas, descendentes dos Caraibebes, abençoavam os guerreiros quando estes partiam para algum empreendimento guerreiro. O Piaga era, portanto, uma espécie de líder religioso dentro de sua tribo: profetizava o futuro, proibia determinadas acçóes e curava os doentes, porque era os conhecedor das plantas e dos fins medicinais de cada uma. No poema, o Piaga conclama todos os guerreiros para ouvirem o seu canto, porque era através dos cantos dos Piagas que os deuses se faziam ouvir junto da tribo.

Constituindo-se, desse modo, num elo entre o mundo material e o espiritual, o Piaga, - intérprete das mensagens dos deuses - é o operador da consciência do destino trágico que estava reservado aos povos indígenas ${ }^{138}$.

$\mathrm{Na}$ estrofe seguinte, a melancolia expóe-se logo na primeira frase: "Esta noite - era a lua já morta" (CP 5). O índio nunca viu a noite com bons olhos. Geralmente, à noite as pessoas não se ausentavam da taba, e quando estavam numa excursão guerreira, juntavam o bando apenas num local para passarem a noite. As guerras faziam-se apenas durante o dia. Entre as poucas actividades que se realizavam no período nocturno, estavam as festas, em que todos se reuniam no centro da taba pela noite dentro. Portanto, ao citar "esta noite", o poeta reúne todos os medos indígenas, porque o poder de Anhangá crescia ao anoitecer (OT 2.88).

Os deuses indígenas eram físicos e Jaci, a divindade protectora dos amantes e da reprodução ${ }^{139}$, era identificada na sua forma material com a lua. A expressão "era a lua já morta" traz consigo o sentido imperativo de que o poder de Jaci deixava de se exercer, pelo que o Piaga cita o raiar do dia, quando os poderes de Anhangá iam enfraquecendo e os de Jaci se dissipando. O Piaga lamenta-se por ser já quase dia, quando ainda Anhangá o impedia já de sonhar; os sonhos nas sociedades primitivas tinham carácter peculiar, porque por intermédio deles os chefes tribais conduziam a sociedade.

Enquanto Anhangá impedia o Piaga de sonhar, o chefe religioso acorda com uma voz rouca que o chamava; abre os olhos, inquieto e medroso, e contempla um pau ardendo de resina fumosa. De repente, surge um fantasma gigantesco a seus pés e um crânio liso ao pé do Piaga, e uma cobra feia, enroscada no cháo. O Piaga sente o sangue gelar nas veias e o corpo tremer pelo horror da visão; sentia o horror penetrar-lhe na pele, o frio

${ }^{138}$ Marques 2006181.

${ }^{139}$ Costa 1934248. 
vento bater-lhe no rosto. Porque o fantasma tinha um aspecto asqueroso, e mais uma vez o Piaga convoca os guerreiros para ouvirem o seu canto.

Ao entrarmos na segunda parte do poema, a Visão começa a falar ao Piaga. A indagação "Por que dormes" se faz ouvir duas vezes (CP 25, 27), porque o chefe religioso dormia como quem náo tinha motivos para se preocupar. E as palavras de tristeza, de ruína, de destruição, ganham vida nas advertências. Veja-se que na primeira parte do poema, a horrenda visão do Piaga era um prenúncio do desespero que tomaria partido na segunda e na terceira parte.

Tu não viste no céu um negrume

Toda face do sol ofuscar;

Não ouviste a coruja, de dia,

Sons estrídulos torva soltar?

Diziam as lendas indígenas que a coruja adivinhava a morte das pessoas. O som estrídulo que a coruja soltava durante o dia era o anúncio de que a morte se aproximava da tribo. Tupá, divindade poderosa que manifestava o seu poder no trováo e no relâmpago, ganhava a sua materialidade maior no sol. Portanto, a face do sol a ocultar de dia significa a perda do poderio de Tupá, facto que seria cantado em Deprecação. A morte anunciada pelo canto da coruja e o negrume a invadir o céu, a copa das árvores no bosque a vergar-se e a gemer, a imagem da lua esfogueada, da cor de sangue, são imagens cruéis da morte que aguardava a tribo do Piaga.

O poeta utilizou o termo Visão para descrever o carácter da ruína que chegaría sobre a taba, carácter esse que encontramos no livro do Apocalipse, ou seja, a destruição de uma naçáo equivale à destruição do mundo ${ }^{140}$. A imagem do sol ofuscado e da lua em vestes de sangue constitui uma referência existente no livro do Apocalipse $e^{141}$.

A segunda parte encerra, conclamando todos a ouvirem os anúncios do fantasma, os sons do fiel Maracá, porque os deuses protectores fugiram da taba. $\mathrm{O}$ grito desesperado demonstra o horror que sobressalta o Piaga por causa da visáo horrenda e da fuga dos deuses da Taba:

${ }^{140}$ Bosi 2001186.

${ }^{141}$ Bosi 2001185. 
Para entrarmos na terceira parte, é necessário estabelecermos uma analogia com a Eneida. Palante, filho de Evandro, é executado por Turno, mas antes de ser abatido grita diante de Turno palavras que expressam a pequenez da morte diante da honra que ele obteria ${ }^{142}$. Evandro não sabia que a aliança com um amigo aparente conduziria à destruição da sua comunidade, representada na morte de Palante ${ }^{143}$.

As palavras da visão do Piaga representada na primeira estrofe da terceira parte do poema, denunciam já a existência daqueles monstros nas flo estas da Taba. Estes "monstros" que estavam na flo esta estabeleceram o seu domínio através da aliança e da troca de matérias-primas indígenas por matérias europeias manufacturadas. A aliança de Evandro com Eneias, que só trouxe a morte e a desgraça ao seio do seu povo, perdendo o seu próprio filho, encontra o seu refle o na união do português com o índio, que também lhe traria a dor e a morte.

Sobressaltado pelo desespero, o Piaga pergunta, na sua Visão, o que o monstro buscava em terras indígenas, e a resposta que o Piaga recebe contém um valor poético de desesperação, em nada inferior a qualquer uma das suas outras obras: o quadro apocalíptico que Gonçalves pintaria posteriormente a esta pergunta é, sem dúvida, o apogeu da beleza desta obra singela que, ao lado da Canção do Exílio e de Deprecação, torna-se a expressão mais comovedora dos Primeiros Cantos.

Não sabeis o que o monstro procura?

Não sabeis a que vem, o que quer?

Vem matar vossos bravos guerreiros,

Vem roubar-vos a filha, a mulher

Vem trazer-vos crueza, impiedade -

Dons cruéis do cruel Anhangá;

Vem quebrar-vos a maça valente,

Profanar Manitôs, Maracás.

Vem trazer-vos algemas pesadas,

Com que a tribu Tupi vai gemer;

${ }^{142}$ André 199241.

${ }^{143}$ Wiesen 1973 754; André 199242. 
Hão-de os velhos servirem de escravos

Mesmo o Piaga inda escravo há de ser?

Fugireis procurando um asilo,

Triste asilo por ínvio sertão;

Anhangá de prazer há de rir-se,

Vendo os vossos quão poucos serão. (CP 61-76)

Morrer na batalha era a maior honra que um guerreiro indígena poderia alcançar. $\mathrm{O}$ indianismo de Gonçalves está repleto de personagens assim: o herói central de I-Juca Pirama; Tabira; o chefe dos Gamelas no canto I de Os Timbiras, entre outras personagens. Mas a morte anunciada em $O$ Canto do Piaga, não se refere às mortes honrosas citadas acima. Perder uma batalha não equivale, para os índios, a perder a honra; pelo contrário, é a prova cabal de sua bravura. A morte referida se tornaria vergonha para os sobreviventes, porque seriam vencidos sem combate. Seriam vencidos a troco das convençóes comerciais das quais se viram vítimas, pouco a pouco; os que não morressem nos campos de batalha tornar-se-iam vítimas da mutação racial.

$\mathrm{O}$ monstro vinha para roubar as filhas e as mulheres dos guerreiros. O poema Marabá é a demonstração fiel dessa mutação racial causada no seio da família indígena. O desfloramento das moças indígenas não ocorria necessariamente no casamento. Conforme já dissemos, os pais muitas vezes recebiam recompensas cedendo as filhas a qualquer varão, e a mestiçagem encontrou nisso a força que precisava para evoluir ${ }^{144}$. Com a chegada dos portugueses ao Brasil, no primeiro registo em língua portuguesa, a carta da descoberta do Brasil de Pêro Vaz de Caminha, o escritor mostrara-se fascinado pelas mulheres índias que andavam completamente nuas, descrevendo-as mais bem feitas do que as mulheres europeias (a índia nua chamou obviamente muito mais a atenção dos colonizadores do que os índios nus).

$\mathrm{Na}$ estrofe seguinte, a visão denuncia que o monstro vinha trazer os dons cruéis do cruel Anhangá; profanar as divindades sagradas e o Maracá. Anhangá era responsável por castigar aqueles que náo vivessem de acordo com os bons costumes, ou que não mostrassem destreza nas batalhas, e que aprisionassem diversos inimigos, sacrificand -os nos rituais de antropofagia ${ }^{145}$.

${ }^{144}$ Fernandes 1989139.

145 Abbeville 1945 252; D’Evreux 1929 294; The et 1944 261; Léry 1941 223; Fernandes 1989164. 
No poema Deprecação, o poeta colocara os portugueses como enviados de Anhangá, que detinham os poderes de Tupã; em $O$ Canto do Piaga, o poeta confirma a mesma versão. Vinham como enviados de Anhangá, com os dons cruéis da cruel divindade, que era castigar os índios. A primeira impressão que os índios tiveram dos portugueses foi a de que estes seriam filhos ou enviados de Tupã, porque estes detinham o poder do trovão, personificados no barulho e na destruição que as armas de fogo produziam. Posteriormente, e já em Deprecação, o poeta figura isto. Os índios perceberiam que os portugueses detinham os poderes de Tupã, embora fossem enviados por Anhangá. Eis o porquê do pessimismo, a razão do anúncio apocalíptico de $O$ Canto do Piaga. O clamor estabelecido no poema Visóes se faz ouvir no canto do Piaga:

Treme - ó povo Tupi - já não és povo

Eleito de Tupã. (V 110-111)

Tupã havia deixado a taba sagrada, o seu rosto coberto com um denso velâmen de penas. As divindades protectoras das tabas haviam fugido. $\mathrm{O}$ monstro haveria de profanar os Manitôs ${ }^{146}$. Prova desta profanação é que os Jesuítas ignorariam quase todas estas divindades indígenas, escolhendo Tupã e Anhangá para representarem, na língua indígena, o mundo sobrenatural governado por Deus e Satanás, o bem e o mal.

$\mathrm{Na}$ estrofe seguinte, o monstro trazia aos índios duras algemas, e transformaria os velhos em escravos, e até mesmo o Piaga tornarse-ia escravo. A imagem que o poeta fornece do futuro insólito e cruel dos Tupis coincide exactamente com o final das tribos Tabajaras no final do poema Tabira, transformados em escravos para o serviço da colonização.

A indicação de que os velhos se tornariam escravos, inclusive o Piaga, é a maior profanação que se pode causar no seio da tribo Tupi. Na cultura primitiva, os velhos possuíam lugar de respeito, porque tinham maiores experiências e conhecimentos e, por isso, estavam incumbidos de educarem os mais novos. Entre os gregos, um príncipe sempre era educado por um velho. Tal sucede com Aquiles educado por Fénix ${ }^{147}$, ou a figura de Mentes por trás do

146 Divindades semelhantes aos Penates romanos.

${ }^{147}$ Jaeger 199550. 
príncipe Telémaco ${ }^{148}$. Porque numa sociedade primitiva tudo está baseado na experiência. Os mais novos não têm experiência, portanto não têm nada para ensinar. Cada geraçáo que alcançava a sua velhice tendia, portanto, a estabelecer os mesmos costumes. A figura de Tabira é a prova de que os velhos serviriam de escravos, porque o chefe Tabajara era experiente. Já havia atravessado diversas guerras. A observância fiel que este faz ao tratado é uma prova de que se tornara escravo dos lusos. Em contrapartida, os lusos traidores dormiam em paz na crença do tratado, porque conheciam o seu fiel se vo.

Na penúltima estrofe, sem dúvida uma das formas inspiradoras de I-Juca Pirama, a visão do Piaga denuncia que os Tupis fugiriam procurando asilo por entre o ínvio sertáo. Em I-Juca Pirama, o prisioneiro vagava com o pai cego pelo ínvio sertão, porque perdera a sua tribo numa razáo ignorada pelo poeta, descrita apenas como as afliçóes do destino que Tupá causou. $\mathrm{O}$ poeta referia-se certamente à fuga dos índios da costa, causada pela ocupação portuguesa, que está prefigurada e testemunhada em O Canto do Piaga.

No último canto, a visão demonstra, no meio de tantos pessimismos, um fio de esperança, porque os deuses indígenas conjuravam interromper a ira de Anhangá:

Vossos Deuses, ó Piaga, conjura,

Susta as iras do fero Anhangá. (CP 77-78)

Porém novamente, como quem lembra o mal que está feito, a visão deixa-se esmorecer, e grita o seu último canto, cheio de desgosto e infortúnio, para depois se calar.

Manitôs já fugira da Taba,

Ó desgraça! ó ruína! ó Tupā! (CP 79-80)

O tom solene que permeia o texto harmoniza-se de tal maneira com os maus presságios revelados pelo Piaga que o complexo rítmico do poema, marcado pelos versos eneassilábicos, é dado pela predominância do anapesto, que se tornou uma espécie de célula rítmica de toda a sua poesia indianista. É da combinação do movimento anapéstico com uma recorrente rima aguda, que marca os segundos e quartos versos das suas vinte quadras, que

${ }^{148}$ Jaeger 199556. 
resulta o tom apocalíptico que percorre as três partes de $O$ Canto do Piaga ${ }^{149}$.

No entanto, as desgraças anunciadas pela natureza trazem consigo um aspecto mais dramático ao destino dos selvagens, uma vez que, ao contrário dos cristáos que podem ser salvos, caso se mantenham fiéis aos ensinamentos e normas de Deus, os índios são empurrados para um beco sem saída, pois o seu destino atroz náo depende da crença nos deuses, já que está directamente relacionado com a presença dos colonizadores lusos que, impiedosos, os condenam tanto à destruição quanto à escravidáo ${ }^{150}$.

O Piaga estava presente em todas as decisóes da tribo. Os sonhos por ele explicados não se separam da realidade física. Para Ricardo ${ }^{151}$, o poeta teria compreendido que o sobrenatural para o índio é que é o natural; do mesmo modo que o natural é o sobrenatural.

Gonçalves confere enorme importância ao "onírico", ao "mágico", aos "ritos semibárbaros do Piaga". O poeta limita-se, contudo, no que diz respeito à teogonia selvagem, a Tupã e Anhangá, referindo-se uma só vez a Caraibebe em Os Timbiras. Não fez menção a Rudá e, no que respeita aos mitos, não alude a Tamuí, Jaci, Saci Pererê, Jurupari, Curupira, Maraguigana, Caapora, Boitatá; nem aos mitos históricos da lenda Tupi, como Sumé e Tamandaré.

A respeito das lendas e do fabulário indígena, ainda mais escasso, Ricardo ${ }^{152}$ indaga "por que não os teria melhor aproveitado?" Só num fragmento de um poema, denominado Poema Americano, que está entre os versos póstumos, é que o poeta resolveu descrever uma das mais poéticas lendas da teogonia Tupi. Gonçalves não se deixou seduzir muito por esse aspecto do nosso indianismo.

É verdade que, noutros poemas, Gonçalves Dias alude ao monstro marinho, que parece confundir-se com o "urupiara" tão falado pelos cronistas coloniais, como Gabriel Soares e Simão de Vasconcelos; à "mãe d'água", uma "Náiade moderna" que habita no fundo dos rios; e ao gigante de pedra, mito que corresponde àqueles gigantes armados, de temerosíssima grandeza, a que alude D. Francisco Manuel de Melo ${ }^{153}$.

${ }^{149}$ Marques 2006 184-185.

${ }^{150}$ Marques 2006189.

${ }^{151}$ Ricardo 196461.

152 Ricardo 196462.

${ }^{153}$ Ricardo 196463. 
O mundo perfeito do passado é a inspiração de toda a poesia indianista. As primeiras palavras do Poema Americano conduzem-nos através da nostalgia a esta época feliz. É neste poema que Gonçalves evidencia o surgimento dos guerreiros indígenas, da discórdia e do que tinha conduzido os nativos à ruína.

Fértil a terra produzia outrora

Deleitosa em abundância: em toda a quadra

Lourejava o caju, pendia o milho

Das verdes hastes - uberosas glebas

Aqui, ali, rachavam-se, mostrando

A macaxeira, o aipi - da vida esp'rança.

Piscoso o rio, as margens povoadas,

Pingue a flo esta, semelhante à fera

Que ao recém-nado filho as tetas dura

Cópia de leite incômodo apresenta,

Tal se mostrava a natureza - outrora. (PA 1-11)

É impossível não percebermos o pessimismo nestas frases, porque o que está em causa não é um passado feliz, mas sim um presente fracassado, um futuro comprometido; a lembrança da terra fértil é algo que pertence ao passado. É nele que os rios possuem as suas margens povoadas. Por detrás desse passado feliz está a morte, a ruína que encontraram. Nos versos seguintes, o poeta denuncia pelas palavras do Piaga quais os reais motivos que levaram à ruína os nativos.

$O$ poeta exalta a sabedoria do Piaga que se tornava mais sábio com o passar dos anos, semelhante ao ipê que ganha mais cerne no tronco. Descortinam entáo as palavras de mau agouro para os nativos, pela boca do Piaga: "os dons do Ibaque, são do Ibaque outra vez, já não são vossos” (PA 23-24). Os deuses dão aos indígenas duas opçóes: rasgar o seio da terra e fecundá-la com ímprobo trabalho (PA 27-33) ou em duras festas enquanto os hinos da vitória soam, com langor celebrar cruentas guerras (PA 45-50). Os índios escolheram a guerra, enquanto o labor ingrato e duro da agricultura deveria ficar por conta da turba mulheril ( A 51-53).

O Piaga prenuncia as duras lides dos guerreiros indígenas: "com arma igual sereis nunca vencidos" (PA 57). Obviamente que o que está por trás disso é a infelicidade daqueles que foram vencidos sem combate, o combate com as armas adequadas, e não com os poderes de Tupá relegados aos portugueses. Após estas 
palavras, o Piaga revela que as discórdias entre as tribos seriam a causa da destruição (PA 60-64).

Mal atendem aos últimos conselhos:

"À guerra! à guerra, amigos - todos bradam, (PA 65-66)

As palavras do poeta denunciam a ingenuidade e a falta de precaução dos indígenas. Mal o Piaga os advertiu acerca do mal que a guerra poderia causar à Tribo, já estavam a bradar pela batalha. Na posse do tacape foi-lhes concedida a posse da terra (PA 82-95); invadiram conquistando, e de sangue se embriagaram, e com o passar dos anos, já nas tabas opulentas, folgavam em ouvir mesclados dialectos, e nem perceberam que iniciaram os combates no seio da Tribo. $\mathrm{O}$ poeta dirige então uma triste pergunta:

- Um Deus, que vale?

Que prestam seus avisos, quando o ódio

Crava raiz na terra ensangüentada,

E à vingança o guerreiro excita e impele? (PA 105-108)

Os nativos não haviam prestado atenção às palavras de precaução que o Piaga lhes ensinou. E o poeta conduz-nos para a terceira parte do poema, para o canto agoureiro da Acauá.

A Acauã é um gaviáo, branco-sujo, que se alimenta de cobras. Segundo a teogonia Tupi, o canto dessa ave era de mau agouro. $\mathrm{O}$ poeta convida à prudência dos indígenas para os sentidos que vinham nos gemidos da Acauá (PA 111). A referência gemido já denota o sofrimento que o poeta quis expressar - de outra forma teria expressado apenas canto. No canto da Acauá estavam os suspiros dos antigos heróis, e que os netos não eram capazes de compreender (PA 112-117).

Na terceira parte do poema, o poeta narra a união entre Cranjé, filho de Imbé, com Taoba. A conquista de inúmeras terras é o fruto da união entre estes chefes indígenas. Após inúmeros triunfos, a terra dá folga aos conquistadores ovantes. Noutra parte, Taoba segue tranquilo pelas flo estas, sem armas, encontrando numa branca praia cintilante muitas donzelas. Mas apenas uma é que interessa o guerreiro: é Tapera, a quem os cariris denominaram. Mal sabia o chefe guerreiro que Tapera seria a causa da desunião no seio da tribo. Queria Taoba que os guerreiros invejassem a mulher que possuía (PA 185-186), mas não sabia o grande mal o aguardava: 
Presa infeliz! funesto encontro aquele,

Mal entra no arraial, vendo-a tão bela

Rudos e feros os coraçóes se enlevam,

Porém de Imbé com mais violência a chama

Se lhe ateia no peito - tudo olvida,

Cedendo ao impulso de fatais desejos,

A empresa começada, a própria glória,

Guerras, conquistas - tudo - desde essa hora,

Daquele ser na posse os seus anelos

Concentra; e fora dele o mundo é nada. (PA 194-203)

Imbé acha-se no direito de possuir Tapera, alegando que a mais bela cabe ao mais valente, e que a ninguém cederá (PA 218219); mas Taoba lhe replica dizendo "- exceto a mim somente" (PA 220), e freme-lhe no peito o ominoso colar. A discórdia inicia-se com a chegada de Tapera, mas essa discórdia já havia sido prenunciada na primeira parte do poema, pelas palavras do Piaga. Na segunda parte, o poeta evidencia o significado do canto da Acauá, cuja expressão carregava os suspiros dos antepassados. O poema parece-nos inacabado, porque a discórdia entre Imbé e Taoba náo se desenvolve, acabando com as palavras de Taoba e com a fremência do seu colar que ostenta orgulhoso.

Todavia, inacabado, Poema Americano é um dos poucos em que o poeta tentou representar as lendas indígenas, salvo o poema Mãe D'água, em que Gonçalves conduz o leitor através dos cantos tristes de uma lenda indígena. Este poema, porém, apresenta elementos bastantes modernos, chegando inclusive muitos críticos a não o reconhecerem como um poema indianista. No entanto, o que evidenciamos aqui é de facto o surgimento das batalhas e da discórdia no seio das tribos nativas; o poeta denuncia que os indígenas escolheram a morte ao escolherem a guerra, porque não prestaram atençáo às palavras do Piaga.

Ironicamente, tendo os restos sombrios dessa violência como substrato, foi projectada sobre o índio uma certa aura de pureza, coragem e capacidade de luta sob condiçóes adversas. A sua nova identidade passaria, inclusive, pela coincidência dos seus algozes terem sido os mesmos que tinham "civilizado" a colónia e agora eram combatidos pelos brasileiros da independência: os portugueses conquistadores ${ }^{154}$.

${ }^{154}$ Corrêa 200686. 


\section{O que há-de ser morto e que é digno de ser morto}

Voltarei gostoso à obscuridade, donde não devera ter saído, e - como um soldado desconhecido - contarei os meus triunfos pelas minhas feridas voltando à habitação singela, onde me correram, não felizes, mas os primeiros dias da minha infância.

Gonçalves Dias

Para Simóes e Pereira Simóes ${ }^{155}$, I-Juca Pirama é considerado o mais perfeito poema épico indianista da literatura brasileira. De facto, o poema tornou-se a obra prima de Gonçalves Dias, por o poeta ter conseguido terminar a obra (tendo em conta que o poema Os Timbiras ficou inacabado, devido à morte precoce do poeta). Todavia, à semelhança da restante produçáo indianista de Gonçalves Dias, esta obra assume todas as convençóes épicas e transforma-se num poema antiépico.

Numa observação sobre I-Juca Pirama, Franchetti ${ }^{156}$ afirmou

No caso, o conflito entre os valores heróicos e a piedade, bem como o fato de o herói ser um dos últimos descendentes de uma "raça extinta", emigrando e levando consigo o pai senil; permitem ver I-Juca Pirama como glosa americana de um dos textos centrais para constituição da cultura ocidental - a Eneida, de Virgílio.

Mas Eneias, herói da epopeia, é um indivíduo conhecido na história, na mitologia e na literatura, cujo nome aparece no título do poema e preexiste à obra de Virgílio ${ }^{157}$. Já o herói gonçalvino não tem nome, move-se num lugar sem fronteiras, num tempo sem delimitação nem história. Mas todos os poemas do indianismo gonçalvino têm um fundo histórico. $\mathrm{O}$ poema trata de lembranças cujo sujeito e objecto pertencem a um mundo irremediavelmente desaparecido. A sua matéria heróica carrega a certeza da extinção dos índios, por causa da chegada do invasor branco ${ }^{158}$.

155 Simóes e Simóes 200549.

156 Franchetti 200763.

${ }^{157}$ Franchetti 200763.

${ }^{158}$ Franchetti 200765. 
O termo grego Agôn prende-se a "ago" que significa levar diante de si, referindo-se ao gado ou aos prisioneiros capturados em guerra. Portanto, o conceito de Agôn designa o resultado de reunir. Pierre Chantraine observa que o sentido mais frequente de Agôn em Homero é o da assembleia para jogos, e por extensão, combate, confronto, conflito, discussáo ${ }^{159}$. Johan Huizinga observa que toda a poesia tem origem no jogo: o jogo sagrado do culto, o jogo festivo da corte amorosa, o jogo marcial da competição. E foi exactamente isto que inspirou Gonçalves Dias no seu poema I-Juca Pirama ${ }^{160}$. De acordo com Cardim ${ }^{161}$, não havia maior festa entre os índios do que as cerimónias de execução e antropofagia dos inimigos.

No meio das tabas de amenos verdores,

Cercadas de troncos - cobertos de flo es,

Alteiam-se os tetos d'altiva nação;

São muitos seus filhos, nos ânimos fo tes,

Temíveis na guerra, que em densas coortes

Assombram das matas a imensa extensão. (JP 1-6)

A paisagem tipicamente indígena, de um ambiente cercado de troncos e coberto de flo es, revela o carácter nostálgico do poema, de um tempo em que as naçóes indígenas viviam em harmonia com a natureza e cultivavam os seus costumes no seio da terra. Gonçalves apossou-se deste ambiente para escrever os costumes da raça extinta; a paisagem ganha conotaçóes épicas ímpares. Os textos épicos gregos e latinos relatavam a vida na cidade. As paisagens nómadas rurais ganharam grandes proporçóes nos textos bíblicos mais antigos, mas, à medida que o tempo avançou, estas histórias migraram para os ambientes urbanos, tais são as diferenças que se percebem entre o Velho Testamento e o Novo Testamento, tal se conjuga entre a conquista do patriarca Abraão e do apóstolo Paulo. Porém, a poética de Gonçalves não está presa às convençóes criadas pelo tempo. Por isso o poeta maranhense nos conduz a um ambiente campestre descrito com a mesma grandiosidade dos ambientes urbanos gregos e latinos.

No meio desse ambiente, surge uma nação de ânimos fortes, temíveis na guerra, que assombravam as outras tribos. $\mathrm{O}$ poeta não esconde as características desta tribo guerreira. Eram rudes,

${ }^{159}$ Coelho da Silva 2006157.

${ }^{160}$ Coelho da Silva 2006161.

${ }^{161}$ Cardim 1939159. 
severos e a sua nobreza consistia em serem sedentos de glória. Aliás, Jaeger ${ }^{162}$ observaria que os heróis gregos requeriam a sua honra em função da sua nobreza; à semelhança dos heróis gregos, os Timbiras sabiam apenas vencer. A guerra, para os povos primitivos só tinha um significado, o da honra. Morrer na guerra significa a "morrer como um herói esforçado ${ }^{163}$." Entre os índios americanos, a honra não estava apenas ao alcance dos vitoriosos. Morrer na batalha era a maior glória que se podia alcançar.

Gonçalves conduz-nos para uma nação Timbira, famosa entre as gentes da flo esta. $\mathrm{O}$ poderio desta tribo tornara-se tão notável entre os povos, que os vizinhos enfraqueceram. A típica paisagem épica grega é substituída pela típica paisagem indígena brasileira, ao passo que os templos gregos, locais tradicionais dos concílios, são substituídos pelo centro da taba:

No centro da taba se estende um terreiro,

Onde ora se aduna o concílio guerreiro

Da tribo senhora, das tribos servis:

Os velhos sentados praticam d'outrora,

E os moços inquietos, que a festa enamora,

Derramam-se em torno dum índio infeliz. (JP 19-24)

As cenas do concílio guerreiro, em torno de um índio que está prestes a ser sacrificado, lembram o concílio entre os guerreiros na tragédia Ifgénia em Áulide, de Eurípides. Ifigénia seria oferecida em sacrifício, em prol dos Aqueus que partiriam para a guerra de Tróia, ao passo que o jovem guerreiro seria sacrificado em nome da honra de sua tribo. O concílio guerreiro épico, em Gonçalves, adquire as proporções das instalaçôes das tabas, pois era no centro destas tabas que ocorriam as principais decisôes e todo tipo de festa, ou quaisquer eventos que fossem comuns aos membros da tribo. O concílio é algo comum entre os povos primitivos. É por eles que toda a vida da comunidade se rege.

No meio da taba está um guerreiro de nome desconhecido; o poeta ignora o nome do herói porque a verdade poética tem maior valor que a verdade histórica. Todavia, o facto de ignorar nomes em ocasióes, como a do bravo Potiguar gritando por Tabira, e do guerreiro valente, em I-Juca Pirama, que está prestes a ser sacrificado, demonstra que a verdade poética, embora superior, não compromete a verdade histórica. Porque o interesse do poeta

162 Jaeger 199531.

163 Jaeger 199528. 
não é fundar uma poesia histórica, mas trazer para sua poesia uma verdade poética que suplanta o sofrimento e a morte pela verdade histórica.

De acordo com Ladeira ${ }^{164}$, as aldeias Timbiras eram circulares e o círculo era formado para que todas as casas distanciassem igualmente do pátio «càd»» que se tornava, assim, centro da aldeia. Cada casa tinha o seu próprio caminho que a ligava ao pátio, e estes caminhos radiais «càà ma pry» eram iguais para todas, o que significa que todas tinham o mesmo peso social e que estavam relacionadas de um mesmo modo ao pátio, centro das decisóes políticas e de toda a vida ritual.

O rito de passagem, cuja preparaçáo é para um banquete em que um bravo Tupi será devorado pelos Timbiras, é necessário para que todos os guerreiros assimilem a força interior, a coragem, a energia Tupi ${ }^{165}$. Logo após, precedendo a alegria e impaciência com que todos esperam a festa, surge uma série de perguntas revestida de uma nota especial.

Quem é? - ninguém sabe: seu nome é ignoto,

Sua tribo não diz: - de um povo remoto

Descende por certo - dum povo gentil; (JP 25-27)

Assim uma sociedade primitiva se comporta como agonística, tal como a arte da luta na antiga Grécia, símile que o próprio poeta fez questão de frisar ${ }^{166}$ :

Assim lá na Grécia ao escravo insulano

Tornavam distinto do vil mulçumano

As linhas corretas do nobre perfil. JP 28-30)

A partir da observância do ritual de sacrifício por Florestan Fernandes ${ }^{167}$, buscamos aqui interpretar as correlativas com o poema I-Juca Pirama. Dentro de sua maloca, na companhia de treze ou catorze guerreiros, o matador pintava-se com tintas extraídas de determinadas raízes, adquirindo a cor plúmbea ${ }^{168}$. Saía da maloca imponente, com todos os projécteis possíveis

${ }^{164}$ Ladeira 198220.

165 Coelho da Silva 2006162.

${ }^{166}$ Coelho da Silva 2006162.

${ }^{167}$ Fernandes 1989 231-235.

168 Gabriel Soares 1938 398; Abbeville 1945 232-233; Figueiredo 1949 101-104. 
do prisioneiro, enfeitado de plumas, barretes, entre outros adornos $^{169}$. Na cabeça trazia uma carapuça de penas amarelas e um diadema e nos braços e nas pernas usava manilhas do mesmo tipo de penas. Sobraçava grandes ramais de contas brancas, possuía um rabo de penas de ema nas ancas, e erguia um tacape ricamente ornamentado ${ }^{170}$. Os tacapes ou clavas eram feitos de uma madeira muito resistente, a tangapema, massa pesada, muito grossa na extremidade inferior, cujo formato de espada a destinava quase exclusivamente ao sacrifício dos prisioneiros ${ }^{171}$. $\mathrm{Na}$ companhia de um cortejo composto por parentes e amigos que entoavam cânticos comemorativos, o matador se punha no local do sacrifício ${ }^{172}$.

A custo, entre as vagas do povo da aldeia

Caminha o Timbira, que a turba rodeia,

Garboso nas plumas de vário matiz.

Entanto as mulheres com leda trigança,

Afeitas ao rito da bárbara usança,

O índio já querem cativo acabar:

A coma lhe cortam, os membros lhe tingem,

Brilhante enduape no corpo the cingem,

Sombreia-lhe a fronte gentil canitar. (JP 40-48)

O matador assume, portanto, a centralidade dos acontecimentos, atingindo com isso a maior honra que lhe será tributada, além da honra já adquirida pelo privilégio de vingar a morte dos seus antepassados, dos seus irmãos e parentes ${ }^{173}$. No local do sacrifício já se encontrava o prisioneiro, pronto para ser executado. $\mathrm{O}$ poeta, porém conduz-nos a outra dimensão.

$\mathrm{O}$ ritmo é essencial no poema. $\mathrm{Na}$ expressão de Afrânio Coutinho ${ }^{174}$, "é como se ouvíssemos a dança, o batepé dos selvagens nos festins." Conforme a associação da segunda parte do poema, de verso curto, de rima aguda, com um longo verso decassílabo ${ }^{175}$.

\footnotetext{
${ }^{169}$ Léry 1941177.

${ }^{170}$ Gabriel Soares 1938 398-400.

${ }^{171}$ Costa 1934236.

172 Gabriel Soares 1938399.

${ }^{173}$ Gabriel Soares 1938399.

${ }^{174}$ Coutinho 1986101.

175 Coelho da Silva 2006161.
} 
Em fundos vasos d'alvacenta argila

Ferve o cauim;

Enchem-se as copas, o prazer começa,

Reina o festim. (JP 49-52)

Os pés dos selvagens é que dominam a cadência dos versos. Sob o movimento dos pés dos índios, está o prisioneiro. Os olhos de ignóbil pranto estão secos, os lábios cerrados não desferem as lamúrias do coração. Após uma descrição do preparo ritual, o poeta propóe um monólogo, como se uma voz estivesse a perguntar a respeito das preocupaçóes do valente tupi, e da sua expectativa de morte ${ }^{176}$. Lembra a brevidade da sua vida e a atitude desdenhosa com que encara o sacrifício. Léry ${ }^{177}$ havia observado que o prisioneiro estava longe de mostrar-se pesaroso diante destes rituais. $\mathrm{O}$ poeta dirige-se a ele, pois não consegue dissimular a sua emoção. Consola-o para que morra satisfeito, com as alegrias que o esperam no Além. Consola-o dizendo que no fundo daquela cena tão cruel, está a honrosa morte que enfrenta; que por detrás desta morte está a honra das tabas que o viram nascer. Porque, além dos Andes, os fortes revivem, e ele soube afrontar orgulhoso a fria morte. Compara o herói com a natureza. Àqueles que são como as rasteiras gramas, expostas ao sol e à chuva, murcham. Somente os troncos que invadem os ares são ofendidos pelos raios.

$\mathrm{Na}$ terceira parte do poema, segue-se o festival dos Timbiras. $\mathrm{O}$ matador recebia das máos de um anciáo o tacape ${ }^{178}$, - de acordo com Cardim $^{179}$, este é o honrado padrinho do novo cavaleiro - e este lhe tomava o ibirapema ${ }^{180}$ passando a arma diversas vezes entre as pernas, metendo ora por uma ou outra parte, - da mesma maneira que os cachorrinhos dos sanfoneiros - passando por entre as pernas e depois tomando pelo meio com ambas as mãos aponta com uma estocada para os olhos do morto; e feito isto, vira-lhe a cabeça para cima da maneira que dela hão-de usar, e mete-a nas mãos do matador ${ }^{181}$.

Em seguida, a imagem do cacique. A definição do cacique da tribo é concebida pela sua força de guerreiro valente. No pescoço do orgulhoso cacique está o símbolo do poderio dos Timbiras ${ }^{182}$ :

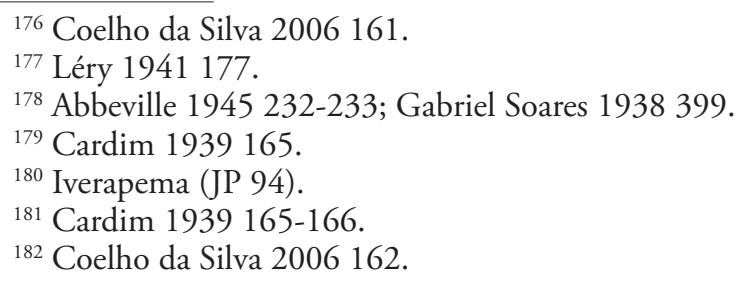


Colar d'alvo marfim, insígnia 'honra

Que lhe orna o colo e o peito, ruge e freme,

Como que por feitiço não sabido

Encantadas ali as almas grandes

Dos vencidos Tapuias, inda chorem

Serem glória e brasão d'imigos feros (JP 96-101)

Foram os primeiros cronistas que aprenderam a língua dos índios e através destes souberam da existência de outras gentes, errantes pelo interior, a quem chamavam Tapuias. Mas Tapuias eram todos os inimigos, todos os povos estranhos ${ }^{183}$. Os inimigos dos Timbiras choravam porque haviam sido vencidos. $\mathrm{O}$ poeta quer com isso não apenas enaltecer o seio da nação Timbira, mas também a importância daquele que há-de ser morto.

Enquanto isto, o prisioneiro observava atentamente os movimentos do matador, e dois homens seguravam as pontas da corda pela qual se encontrava amarrado. Isso dava alguma condição de luta ao prisioneiro, que eventualmente tentaria tomar a arma do matador ${ }^{184}$, e por vezes conseguia, colocando o matador em má situação. Mas, por intermédio dos demais camaradas que intervinham e tomavam a arma do prisioneiro, que obviamente lutava para a não devolver ${ }^{185}$, o ritual restabelecia-se, e raramente a vítima escapava, porque estava sozinho entre muitos guerreiros.

Nisto aparelha-se um para furtar o corpo, o objecto de honra do sacrifício; por vezes, já o dia avançava sem que o prisioneiro fosse morto, porque ao ver a espada pelo ar, ora desviava a cabeça, ora lhe furtava o corpo, expondo o matador a situaçóes ridículas ${ }^{186}$, já que não podia ameaçar sem desferir o golpe. Se o fi esse, seria vaiado pelos companheiros. $\mathrm{O}$ que dava ao prisioneiro vantagens no furtar do corpo $^{187}$. Mas, por intermédio dos companheiros que seguravam as pontas da corda, e com isso conseguiam imobilizar o prisioneiro, o matador poderia em determinado momento desferir o golpe fatal. Com uma ou duas marretadas atrás da orelha e com um golpe brusco no crânio, fazia saltar os miolos da vítima ${ }^{188}$.

${ }^{183}$ Costa 1934151.

${ }^{184}$ Abbeville 1945 232-233.

${ }^{185}$ Cardim 1939 166-167.

${ }^{186}$ Cardim 1939 166-167; Abbeville 1945 232-233; Costa 1934 245-246.

${ }^{187}$ Cardim 1939167.

${ }^{188}$ Abbeville 1945 232-233; Cardim 1939 167; Gabriel Soares 1938 399; 
Porém, antes de matá-lo, o matador volteava diante do prisioneiro, ameaçando com o tacape e travando com ele um rápido diálogo ${ }^{189}$. É para esta esfera que Gonçalves nos leva no final da terceira parte do poema. Disse-lhe o matador que estava ali para matá-lo:

Eis-me aqui, diz ao índio prisioneiro;

Pois que fraco, e sem tribo, e sem família,

As nossas matas devassaste ousado,

Morrerás morte vil da mão de um forte. (JP 102-105)

O prisioneiro respondia normalmente no mesmo tom. Isto dava-lhe o privilégio de fazer o seu canto de morte conhecido entre a tribo, quando deveria cantar os feitos de guerra e de vida ${ }^{190}$. Para Coelho da Silva ${ }^{191}$, este diálogo em grego seria um Agôn. Porque o discurso entre o valente chefe Timbira e o guerreiro Tupi configur -se à semelhança dos encontros entre os heróis da épica clássica grega e latina, quando relatavam a sua genealogia e expunham os seus epítetos, que eram a síntese dos seus feitos heróicos ${ }^{192}$. Aquiles, por exemplo, é muitas vezes referido pelos seus epítetos: o filho de Tétis, o dos pés ligeiros, o melhor dos aqueus,etc.

De acordo com Sáez ${ }^{193}$, este é um dos discursos mais famosos da etnologia das Terras Baixas, porque a vítima do banquete antropofágico Tupinambá poderia proferir um discurso pouco antes de ser abatida, e era precisamente uma alocução autobiográfica, em parte equivalente aos coup tales norteamericanos, embora as façanhas da vítima se enlaçassem nele com as dos seus predecessores e as dos seus herdeiros, girando em torno da vingança.

O prisioneiro de I-Juca Pirama entoa o seu canto com voz tristonha. Primeiro começa por se apresentar como Tupi, evocando as desgraças da sua tribo, que vive errante e perseguida por um cruel destino.

Léry 1941 179; Gândavo 1922 133-134; Nóbrega 1931 100; The et 1944 244; Huxley 1963290.

${ }_{189}$ Abbeville 1945 232-233.

${ }^{190}$ Cardim 1939 166; Gândavo 1922 51; Huxley 1963290.

${ }^{191}$ Coelho da Silva 2006162.

${ }_{192}$ Coelho da Silva 2006162.

${ }^{193}$ Sáez 2006186. 
Meu canto de morte,

Guerreiros, ouvi:

Sou filho das sel as,

Nas selvas cresci; (JP 112-115)

Mais tarde, por causa da hostilidade dos conquistadores, os índios da orla marítima embrenharam-se flo esta dentro, rumo ao centro do continente, daí juntando-se aos demais povos Tapuias ou combatendo ${ }^{194}$. Gonçalves encontrou nisto o campo fértil de que precisava para a produçáo do poema I-Juca Pirama e de toda a sua poesia indianista.

O canto de morte do bravo Tupi relembra uma época pujante da sua tribo, cuja cultura ainda estava presa à sua raíz, sem as alteraçóes do homem branco; mas em poucas palavras o poeta revela que o jovem Tupi perdera a sua tribo nas guerras. Sem perceber como, o jovem guerreiro, na companhia do seu pai embrenhou-se nas selvas, sobre territórios inimigos (claramente aqui o poeta pretende aludir à invasão dos lusos sobre os territórios dantes Tupis) e, errante, em busca de meios necessários à sobrevivência, é que o jovem Tupi acaba prisioneiro da tribo Timbira.

Guerreiros, descendo

Da tribo Tupi.

Da tribo pujante,

Que agora anda errante

Por fado inconstante,

Guerreiros, nasci;

Sou bravo, sou forte,

Sou filho do orte;

Meu canto de morte,

Guerreiros, ouvi. (JP 116-125)

Após apresentar-se como descendente dos bravos Tupis, o jovem guerreiro canta as suas próprias façanhas, os factos da sua vida errante, perseguida por um destino cruel.

Já vi cruas brigas,

De tribos imigas,

$\mathrm{E}$ as duras fadigas

Da guerra provei;

${ }^{194}$ Costa 1934181. 
Nas ondas mendaces

Senti pelas faces

Os silvos fugaces

Dos ventos que amei.

Andei longes terras,

Lidei cruas guerras,

Vaguei pelas serras

Dos vis Aimorés;

Vi lutas de bravos,

Vi fortes - escravos!

De estranhos ignavos

Calcados aos pés.

E os campos talados,

$\mathrm{E}$ os arcos quebrados,

E os piagas coitados

Já sem maracás;

E os meigos cantores,

Servindo a senhores,

Que vinham traidores,

Com mostras de paz

Aos golpes do imigo

Meu último amigo,

Sem lar, sem abrigo

Caiu junto a mi!

Com plácido rosto,

Sereno e composto,

$\mathrm{O}$ acerbo desgosto

Comigo sofri. (JP 126-157)

A morte do último amigo do bravo prisioneiro lembra a evocação de Eneias que assiste à morte de Príamo e vê o corpo do rei decapitado na areia do mar. Virgílio fez de Eneias um herói melancólico, que perdeu um passado e que corre atrás de um futuro que nunca verá. Gonçalves também fez do jovem Tupi um guerreiro sorumbático, que perdeu um passado e que vê o seu futuro suprimido precocemente, porque a sua honra consiste na sua morte.

O Herói de I-Juca Pirama é semelhante a Eneias, pois para o herói troiano, a vida também é sofrimento. A alta missão de que foi divinamente investido é um fardo. Transporta aos ombros o pai (o passado) e no momento em que caminha para o futuro é o 
fardo que leva (o escudo); o presente, uma obrigação. A sua voz ergue-se para contar (cantar) o passado, nunca para falar da sua missão. E assim, preso ao passado, esquecendo o seu presente e preparando o futuro que não verá, Eneias não é um herói feliz ${ }^{195}$.

Eneias não compreende que, para o seu amadurecimento, era forçoso que o pai, até então o principal dinamizador da viagem, desse lugar à iniciativa do filh . Não pode compreender que a sua missão the exija desprendimento pelos afectos do passado, o desprendimento do passado ${ }^{196}$. De acordo com Medeiros ${ }^{197}$, "o passado deve morrer - e, no entanto, náo morre. Ressuscita logo à partida, na dor e na saudade."

Eis o fardo de que dispóe o herói central de I-Juca Pirama: está incumbido de honrar a sua tribo, como o último guerreiro a morrer pela honra do nome dos Tupis. Ao passo que, ao morrer, viverá em nome da honra do seu povo. Mas também possui um fardo, está preso ao passado e é sua obrigação desprendê-lo de si.

A cidade de Tróia tem uma enorme importância na vida de Eneias: "The importance of Troy in Aeneas's spiritual life may be seen in his tale of the Fall of Troy ${ }^{198}$." E o herói recusa partir mesmo quando não há esperança, recobrando o ânimo dos seus colegas para que se precipitem na batalha e para que nela morram sem abandonar as muralhas da cidade. Da mesma forma, o pai exerce um papel singular na vida do jovem Tupi; nos instantes em que tem de decidir entre o amor filial e a honra tribal, o guerreiro não hesita. $\mathrm{O}$ que transforma a obra épica de Gonçalves em antiépica é o carácter humanístico das suas personagens, porque agem pelas paixóes que possuem, à semelhança dos heróis virgilianos.

Meu pai a meu lado

Já cego e quebrado,

De penas ralado,

Firmava-se em mi:

Nós ambos, mesquinhos,

Por ínvios caminhos,

Cobertos d'espinhos

Chegamos aqui!

${ }^{195}$ V. Pereira 199282.

${ }^{196}$ V. Pereira 199289.

${ }^{197}$ Medeiros 199214.

${ }^{198}$ Di Cesare 197437. 
O velho no entanto

Sofrendo já tanto

De fome e quebranto,

Só qu'ria morrer!

Não mais me contenho,

Nas matas me embrenho,

Das frechas que tenho

Me quero valer.

Então, forasteiro,

Caí prisioneiro

De um troço guerreiro

Com que me encontrei:

$\mathrm{O}$ cru dessossego

Do pai fraco e cego,

Enquanto não chego,

Qual seja — dizei!

Eu era o seu guia

$\mathrm{Na}$ noite sombria,

A só alegria

Que Deus lhe deixou:

Em mim se apoiava,

Em mim se firma a,

Em mim descansava,

Que filho lhe sou

Ao velho coitado

De penas ralado,

Já cego e quebrado,

Que resta? - Morrer.

Enquanto descreve

$\mathrm{O}$ giro tão breve

Da vida que teve,

Deixai-me viver! (JP 158-197)

O jovem guerreiro adquiriu as mesmas proporçôes de Eneias. É o responsável pela sobrevivência do pai que era cego (o passado) e, no momento caminha para o futuro (a morte honrosa em virtude de ser o último da raça dos Tupis); o presente é uma obrigação. A sua voz ergue-se para cantar o passado, mas não fala da sua missão. E assim, preso ao passado, esquecendo o seu presente e preparando o futuro que náo virá, o herói central do poema é 
tomado de um sofrimento excêntrico, porque tem de optar entre o amor paternal (passado) e a honra da sua tribo (futuro).

A fim de comover os que o ouvem, fala da triste situaçáo do pai, cego e quebrado. Opondo a solidão do velho (que se encontra na mata, sozinho e desamparado), à segurança que ele, como filho, lhe costuma proporcionar, o prisioneiro espera despertar a compaixão dos ouvintes, para que ouçam as súplicas que lhes vai fazer: que lhe poupem a vida enquanto o pai for vivo. Repele, porém, de antemão, a suspeita de covardia, prometendo voltar à aldeia como escravo.

Em relação à fidelidade pelos tratados de Tabira, o amor do Índio em $O$ Canto do Índio lembra o amor de Dido para com Enéias, porque ambos sucumbem pelos sentimentos arrebatadores. $\mathrm{O}$ amor pelo pai, em I-Juca Pirama, é a figura de Eneias, que se sente preso ao pai; consideremos que os velhos tinham na sociedade primitiva um local destacado pelos conhecimentos que possuíam. A figura paternal, como único sobrevivente familiar, desperta nestes heróis sentimentos dos quais têm que se desprender para alcançar o futuro.

Preso ao amor filial, clamando pela vida, o jovem guerreiro encerra o seu canto com a afirmação de não sentir vergonha de suas lágrimas pois apesar de rogar pela vida, sabe morrer honrosamente.

Não vil, não ignavo,
Mas forte, mas bravo,
Serei vosso escravo:
Aqui virei ter.
Guerreiros, não coro
Do pranto que choro;
Se a vida deploro,
Também sei morrer. (JP 198-205)

No poema Tabira, o poeta lembra que os mortos deixados no campo de batalha foram invejados pelos índios que tanto amaldiçoam a escravidão. $\mathrm{O}$ poeta insiste na ideia enunciada na legenda inicial, já uma vez repetida na sétima estrofe: se o negro pode suportar o horror da escravidão, o índio prefere suportar a morte ${ }^{199}$. Quando caíam prisioneiros recusavam o alimento e quase sempre morriam de inanição e quiçá de saudade da vida

${ }^{199}$ Ackermann 1964102. 
liberta que levavam ${ }^{200}$. Porém, o herói da trama, à semelhança do Índio de $O$ Canto do Índio, deseja ser escravo.

$\mathrm{O}$ prisioneiro do poema lamenta a sua sorte, tal como no testemunho de Léry, em que dois portugueses próximos da fortaleza de Morpion defenderam-se desde a manhá até a tarde. Mas os selvagens queriam apanhá-los vivos, e tal sucedeu depois de esgotada a munição, embora se defendessem bravamente pela espada. Na aldeia arrancaram-lhes as barbas, e estes homens flagelados lamentavam-se, enquanto os vitoriosos zombando perguntavam: “- Como depois de vos terdes tão valentemente defendido mostrais menos coragem do que mulheres, agora que devíeis morrer com honra?201" E já teria observado Léry que a mulher também não temia este tipo de morte $^{202}$. Mas os portugueses não escaparam à morte, como também sucedera a Antônio, índio cristáo, que estivera em Portugal: havia abandonado os seus hábitos de antropofagia e solicitou a Léry e aos seus amigos que o salvassem da morte inevitável. No dia seguinte, quando Léry aparece com a intenção de salvá-lo, encontrou apenas os pedaços de Antônio postos no moquém ${ }^{203}$.

O canto de morte do jovem Tupi é uma inovação gonçalvina; de acordo com os modelos de cantos de morte descritos pelos primeiros cronistas, o prisioneiro náo se mostrava fraco e imbele. Pelo contrário, a morte antropofágica era motivo de honra maior. Este facto fora utilizado por Santa Rita Durão na obra Caramuru. Mas Gonçalves trata o índio pelas suas paixôes, por isso Moisés o denomina de poeta-emoção ${ }^{204}$.

$\mathrm{O}$ canto de morte provoca a repulsa no chefe Timbira, que autoriza a libertaçáo do prisioneiro da sua tribo, causando grande espanto dos guerreiros.

Soltai-o! — diz o chefe. Pasma a turba;

Os guerreiros murmuram: mal ouviram,

Nem pode nunca um chefe dar tal ordem!

Brada segunda vez com voz mais alta,

Afrouxam-se as prisões, a embira cede, (JP 206-210)

Oheróisentimental estava dispostoasacrificar pragmaticamente o código de honra à afeição, mas erra no julgamento ao supor que

\footnotetext{
${ }^{200}$ Figueiredo 1949157.

${ }^{201}$ Léry 1941184.

${ }^{202}$ Léry 1941179.

${ }^{203}$ Léry 1941 183-184.

${ }^{204}$ Moisés 198935.
} 
os seus captores o compreenderiam, e que o pai o acusaria de ingrato, caso o abandonasse por uma morte gloriosa ${ }^{205}$.

— Timbira, diz o índio enternecido,

Solto apenas dos nós que o seguravam:

És um guerreiro ilustre, um grande chefe,

Tu que assim do meu mal te comoveste,

Nem sofres que, transposta a natureza,

Com olhos onde a luz já não cintila,

Chore a morte do filho o pai cansado

Que somente por seu na voz conhece. (JP 212-219)

Ao proferir as palavras de gratidão, o prisioneiro é surpreendido com as ordens bruscas do chefe Timbira, porque só aqui é que percebe que náo fora compreendido, e aqui iníciou os primeiros indícios de arrependimento por haver chorado diante da morte:

—És livre; parte.

- E voltarei.

- Debalde.

— Sim, voltarei, morto meu pai.

— Não voltes! (JP 220-221)

Mas o prisioneiro é rejeitado porque se mostrou covarde e justamente por isso quer salvar a sua honra e a da tribo a que pertence, não quer ir embora. Mesmo assim é dispensado ${ }^{206}$. O jovem Tupi vê-se invadido de um arrependimento que tende a crescer até ao desfecho da obra.

É bem feliz, se existe, em que não veja, Que filho tem, qual chora: és liv e; parte!

- Acaso tu supóes que me acobardo,

Que receio morrer!

—És livre; parte!

- Ora não partirei; quero provar-te

Que um filho dos Tupis vive com honra,

E com honra maior, se acaso vencem,

Da morte o passo glorioso afronta.

- Mentiste, que um Tupi não chora nunca,

$\mathrm{E}$ tu choraste!... parte; não queremos

Com carne vil enfraquecer os fortes. (JP 222-232)

${ }^{205}$ Franchetti 200768.

${ }^{206}$ Ackermann 1964 105-106. 
As palavras do chefe Timbira tornam-se a causa da amargura do jovem Tupi, o sentimento filial que se mostrara táo denso agora é encoberto pela vergonha de haver chorado diante da morte. A tentativa de reatar-se como prisioneiro a fim de que o ritual se cumpra, falha.

Os índios são nobres, valentes guerreiros, que não temem nem choram ante a morte ${ }^{207}$. Estas palavras penetraram no íntimo do prisioneiro, que agora se recusa a partir, ao passo que os Timbiras se recusam a aceitá-lo como prisioneiro.

A tristeza do prisioneiro está manifesta no poema, curvado o colo, taciturno e frio. Os termos taciturno e frio revelam o carácter do empreendimento que é o poema. Revela o próprio carácter com que o Tupi deixa os Timbiras, taciturno e frio. Assim está a sua alma, numa luta dolorosa entre o amor filial e a honra da tribo, prevalecendo inicialmente a afeição ao pai ${ }^{208}$.

Curvado o colo, taciturno e frio,

Espectro d'homem, penetrou no bosque! (JP 242-243)

É, sobretudo, sugestiva e impressionante a cena desenvolvida na sexta parte, onde o filho retorna para junto do pai. Uma parte épica vem precedida de um diálogo e seguida de outro, os quais esboçando a situação em que o filho há pouco se encontrava, autenticam no pai a convicção do que de facto se passou. No primeiro desses diálogos, o filho, voltando com provisóes para junto do pai que o espera, pretexta, para explicar a longa demora, ter-se perdido na mata, propondo partirem imediatamente.

— Tardaste muito!

Náo era nado o sol, quando partiste,

E frouxo o seu calor já sinto agora! (JP 247-249)

Mas o jovem guerreiro demonstra-se apreensivo com as coisas que acabaram de lhe suceder. Mantém ainda no coração a sua indecisão entre ter partido ou ter ficado, entre ajudar o pai ou ter-se deixado morrer, no ritual a que se vira obrigado.

Geralmente, quando um prisioneiro ia ser executado, era enfeitado antes de morrer. Limpavam-lhe o rosto e toda a penugem, e untavam-no com o leite de certa árvore que pega

${ }^{207}$ Kothe 1997267.

${ }^{208}$ Ackermann 1964 106; Coelho da Silva 2006162. 
muito. Sobre ele colocavam certo pó de determinadas cascas de ovos verdes de uma espécie de ave do mato, depois untavam todo o corpo até os pés, e enchiam-no todo de penas que para isto já tinham picadas e pintadas de vermelho. Isto fazia o rosto parecer um tanto maior e luzente, e os olhos menores, criando como que uma horrenda visão ${ }^{209}$.

Procura o filho, tacteando as t evas

Da sua noite lúgubre e medonha.

Sentindo o acre odor das frescas tintas,

Uma idéia fatal correu-lhe à mente...

Do filho os memb os gélidos apalpa,

$\mathrm{E}$ a dolorosa maciez das plumas

Conhece estremecendo: - foge, volta, encontra sob as mãos o duro crânio, Despido entáo do natural ornato!... Recua aflito e pávido, cobrind Às mãos ambas os olhos fulminados, Como que teme ainda o triste velho De ver, não mais cruel, porém mais clara, Daquele exício grande a imagem viva Ante os olhos do corpo afigurada Não era que a verdade conhecesse Inteira e táo cruel qual tinha sido; Mas que funesto azar correra o filho Ele o via; ele o tinha ali presente; E era de repetir-se a cada instante. A dor passada, a previsão futura E o presente tão negro, ali os tinha; Ali no coração se concentrava, Era num ponto só, mas era a morte! (JP 267-290)

$\mathrm{O}$ velho Tupi tem todos os sentidos apurados. O ouvido e uma misteriosa intuição forneceram-lhe os primeiros indícios. O olfacto, acusou-lhe o cheiro das tintas usadas nos rituais de antropofagia e, pelo tacto, reconheceu os adornos utilizados. Temeroso com o que havia acontecido, sente os gélidos membros do filh . O velho pergunta então ao filho os motivos dos adornos, embora já os conhecesse de facto. Ao tomar conhecimento de que o filho fora aprisionado pelos Timbiras, pensa que o filho teria quebrado a corda com que os índios atavam os prisioneiros:

${ }^{209}$ Cardim 1939164. 
- E a muçurana funeral rompeste,

Dos falsos manitôs quebraste a maça...

— Nada fiz... aqui estou. JP 293-295)

$\mathrm{Na}$ narração épica que constitui a parte central, o poeta descreve como o anciáo se esforça para desvendar o "que misterioso" e a "impiedosa fraude" do filh . O cego, aplicando todos os sentidos de que dispóe, vai descobrindo progressivamente a triste verdade que receara e pressentira.

Assalta-o um pensamento terrível ao sentir o cheiro das tintas; retrocede assustado ao agarrar o ornato de plumas. Torna a estender a mão para certifica -se cabalmente. Pela justaposição dos dois verbos "foge, volta" o poeta retarda ainda a maior elevação dramática, a fim de a tornar mais arrebatadora um pouco adiante, quando o cego apalpa a cabeça rapada do filh .

Tendo-se certificado do principal facto - a sorte que ameaçara o filho, e da qual este se livrara - o velho dirige o seu pensamento para o futuro, para onde prolonga também a sua dor. A bárbara realidade do presente, o passado cheio de atribulaçóes concentrase num só alvo: a morte.

O diálogo de frases abruptas rompe-se com a tensão representada pela ânsia de certeza que se intensificara no espírito do velho Tupi. Quer ouvir a verdade da boca do filh . O filho, limitando-se a responder concisamente às perguntas do pai, procura encobrir o verdadeiro motivo de sua libertação. Pelo silêncio de ambos, o diálogo sofre uma interrupção, que acusa o embaraço do pai quando o jovem lhe contradiz a única explicação que lhe parecia provável: ter rompido as prisóes com violência.

— Tu és valente, bem o sei; confesso,

Fizeste-o, certo, ou já não foras vivo!

— Nada fiz; mas souberam da existênci

De um pobre velho, que em mim só vivia... (JP 297-300)

O velho Tupi insiste nesta proposição, até que o jovem confessa, afinal, uma parte da verdade, mas sem contar o essencial. $\mathrm{O}$ poeta não anuncia por que motivo o velho tupi resolve ir à aldeia. Resume tudo na pergunta do filho

— E quereis ir?... (JP 304) 
À pergunta cristaliza-se o susto que dele se apodera, ao perceber que o pai está disposto ao mais duro golpe que o pode atingir, pois ouvirá a verdade e a acusação de covardia ${ }^{210}$. O velho faz o filho marchar na direcção da taba, para continuação do ritual interrompido ${ }^{211}$, embora o pai ainda não tivesse conhecimento da covardia do filh .

O Velho Tupi inflexí el sintetiza e personifica os valores cavaleirescos que coordenam o mundo heróico; mesmo em desgraça, mantém o alto orgulho das suas proezas guerreiras, renuncia ao único afecto que lhe restaria e à própria possibilidade de subsistência ${ }^{212}$.

Entre a sexta e a sétima parte do poema, o poeta nos conduz abruptamente para a cena do sacrifício. Já as primeiras palavras sintetizam o engano do velho, que começa enaltecendo o espírito magnânimo dos Timbiras. De forma irónica diz que os Tupis não seriam capazes de tal generosidade. Assegurando que nunca foi vencido por quem quer que fosse, recusa implicitamente a nobre acção e intima os Timbiras a prosseguirem e a continuarem com o ritual.

Vós, guerreiros, concedestes

A vida a um prisioneiro.

Ação tão nobre vos honra,

Nem tão alta cortesia

Vi eu jamais praticada

Entre os Tupis - e mas foram

Senhores em gentileza.

"Eu porém nunca vencido,

Nem os combates por armas

Nem por nobreza nos atos;

Aqui venho, e o filho trag .

Vós o dizeis prisioneiro,

Seja assim como dizeis;

Manda! vir a lenha, o fogo,

A maça do sacrifício

E a muçurana ligeira:

Em tudo o rito se cumpra! (JP 307-323)

Relatando alguma da sua experiência entre os índios brasileiros, Léry afirma que conseguiu, mediante a quantia de

${ }^{210}$ Ackermann 1964107

${ }^{211}$ Coelho da Silva 2006162.

${ }^{212}$ Franchetti 200768. 
quase três mil francos em mercadoria, resgatar uma mulher e o seu filho de dois anos. Pretendia Léry levar a criança para a Europa, mas Villegagnon mandou-o restituir a mercadoria e ficou com os escravos. Quando Léry disse à índia a sua intenção, esta respondeu-lhe que esperava que o seu filho crescesse e dali fugisse para se reunir aos maracajás e vingar-se dos Tupinambás. Léry conclui, no entanto, que a índia preferia ver o filho comido pelos tupinambás do que levado para longe de $\mathrm{si}^{213}$. Embora esta seja uma afirmação duvidosa, porque o desejo da máe era o de vingança, Léry compreendeu o sentimento arreigado que subsistia no coração da índia ${ }^{214}$.

O velho lembra a solidão que o aguarda com a perda do filh . Exprime com convicção que, sem dúvida, algum jovem da tribo dos Timbiras se sentiria honrado em substituir o filho como guia e guarda do velho herói coberto de cicatrizes ${ }^{215}$.

E quando eu for só na terra,

Certo acharei entre os vossos,

Que táo gentis se revelam,

Alguém que meus passos guie;

Alguém, que vendo o meu peito

Coberto de cicatrizes,

Tomando a vez de meu filho, JP 324-330)

A antropofagia indígena tinha um carácter mágico, servia como punição da injúria e da profanação do carácter sagrado do Nós colectivo ${ }^{216}$.

\section{— Nada farei do que dizes:}

É teu filho imbele e fraco! JP 336-337)

A resposta do chefe Timbira ataca o espírito do velho Tupi. Neste instante é que verifica a sua ilusão. Da sua boca desprendem-se sons articulados, precedendo uma violenta irrupçáo de cólera, que se vai derramar sobre o filho como terrível maldiçáo. Somente os maus, efeminados e os covardes consumiam-se na danação eterna. Anhangá atormentaria aqueles que não tivessem vivido de acordo com os bons costumes, que náo tivessem mostrado valor nas guerras,

${ }^{213}$ Léry 1941175.

${ }^{214}$ Léry 1941175.

${ }^{215}$ Ackermann 1964108.

${ }^{216}$ Fernandes 1989236 
ou aprisionado numerosos inimigos, sacrificand -os ritualmente ${ }^{217}$, e o filho tinh -se mostrado imbele e fraco diante da morte.

A surda voz na garganta

Faz ouvir uns sons confusos,

Como os rugidos de um tigre,

Que pouco a pouco se assanha! (JP 345-348)

Repelindo o filho, o pai deseja que se torne presa dos vis Aimorés, tidos como os indígenas mais ferozes e cruéis ${ }^{218}$. Eram índios de estatura agigantada ${ }^{219}$ e que jamais perdoavam os seus inimigos. A sua maldição estende-se além da morte. Que nenhum amigo se ache para enterrá-lo de acordo com o costume da tribo. E no meio dessa maldição, o herói tem de escolher, ou morrer em nome da honra da tribo, ou viver a maldição que lhe foi imposta. Uma coisa permanece como certa - a tribo que lhe deu a vida, requere-a neste momento.

Tu choraste em presença da morte?

$\mathrm{Na}$ presença de estranhos choraste?

Não descende o cobarde do forte;

Pois choraste, meu filho não és! JP 349-352)

O filho fora punido pela repulsa, e só aqui compreende o abismo entre a compulsão do sentimento e a lei da honra. Então, para encontrar acolhimento e redenção, em ambos os universos, o paternal e o dos inimigos, subordina-se finalmente ao código comum, que os rege e anima ${ }^{220}$. Mas proferidas as palavras, em linguagem puramente poética, o poeta inicia a nona parte da obra, traçando em imagem bastante merencória, a descrição da figura do elho Tupi que se retira para a mata.

Vai com trêmulo pé, com as mãos já frias

Da sua noite escura as densas trevas

Palpando. - Alarma! alarma! - O velho para.

O grito que escutou é voz do filho

Voz de guerra que ouviu já tantas vezes

Noutra quadra melhor. - Alarma! alarma! (JP 400-405)

${ }^{217}$ Abbeville 1945 252; D’Evreux 1929 294; The et 1944 261; Fernandes 1989164.

${ }^{218}$ Ackermann 1964108

${ }^{219}$ Figueiredo 1949155.

${ }^{220}$ Franchetti 200768. 
A descrição tristonha do velho caminhando lentamente, com passo incerto, é interrompida subitamente pelo grito de guerra, "Alarma! Alarma!" De acordo com Coelho de Castro ${ }^{221}$, Gonçalves Dias age como se estivesse esculpindo. O seu cinzel imprime um empréstimo italiano em vogal temática, pela precisão etimológica da expressão italiana "Alle arme", "para as armas".

Entre os gregos, o tema essencial da formação é o conceito de Arete. Não há na língua portuguesa um equivalente exacto, mas a palavra "virtude" é o conceito mais próximo, não pelo conceito moral, mas pela expressão do mais alto ideal cavaleiresco, a conduta cortês e distinta do heroísmo guerreiro ${ }^{222}$. O prisioneiro Tupi, enfim, estava próximo de restituir os seus ideais cavaleirescos, que havia comprometido diante dos sentimentos amorosos que tanto embaraçam os humanos.

Este momento supera, sufoca e desfaz todos os tormentos porque o velho passou como pai e guerreiro orgulhoso de sua tribo. E agora realiza-se o que antes a dor atroz náo conseguira: a tensão interior desfaz-se em lágrimas e a tristeza se transforma em alegria.

Após o grito de guerra, o poeta apresenta em poucas palavras uma série de detalhes: pinta um vivo e impressionante quadro do rebuliço da luta. Salienta de um lado o grande número de inimigos e, do outro, o jovem Tupi batendo-se heroicamente, como último rebento da estirpe Tupi. Pelo nome e pela honra da sua gloriosa tribo, cujo esplendor estava prestes a apagar-se.

"Este, sim, que é meu filho muito amado

"E pois que o acho enfim, qual semp e o tive,

"Corram livres as lágrimas que choro,

“Estas lágrimas, sim, que não desonram.” (JP 436-439)

Gonçalves Dias constrói um herói sentimental ${ }^{223}$, porque náo assumiu convençóes divinas para o herói, mas características puramente humanas. Toda a boa aventurança do sacrifício consiste em morrer com valentia ${ }^{224}$. Para Franchetti ${ }^{225}$, a sua honra guerreira, assim como a sua morte, é um sacrifício oferecido ao

${ }^{221}$ Coelho da Silva 2006163.

222 Jaeger 199525.

${ }^{223}$ Franchetti 2007 65-66.

${ }^{224}$ Cardim 1939162.

${ }^{225}$ Franchetti 200768. 
pai, ou em nome do pai. E por isto ecoam tão fortes nas palavras do velho tupi "- Este, sim, que é meu filho muito amado!" - as palavras que se ouvem também no momento da transfiguração de Cristo: "Este é Meu Filho muito amado, no Qual pus todo o Meu enlevo; escutai-O ${ }^{226}$."

As palavras do velho tupi revelam: este sim é meu filho, não o outro, o covarde, que aflo ou por um momento e se dissipou ${ }^{227}$. Quando o filho corresponde com aquilo que o seu pai esperava, o pai abraça-o novamente como filho muito amado. Tal sucederia com Cristo. Quando enfim terminassem as suas dores na cruz, poderia ocupar o seu lugar honroso, à dextra do pai. A morte no meio dos inimigos, o ser devorado por uma causa justa era motivo de honra para os índios ${ }^{228}$.

Ao compararmos o poema épico gonçalvino com a epopeia virgiliana, nota-se que Eneias parte para a futura restauração de Tróia, para a fundação de uma nova nação, uma nova raça, o que torna moralmente mais importante que o colapso e a destruição de Tróia, mas o retorno, a nostalgia profunda é uma indicação de pessimismo ${ }^{229}$. O herói de I-Juca Pirama, após o seu canto de morte, parte para se desprender do passado, mas o acto de chorar diante da morte compromete a sua honra e também a da sua própria tribo, conseguindo somente restaurá-la quando finalmente se desp ende do seu passado.

Quando Medeiros ${ }^{230}$ fala sobre a morte, afirma que "a morte tem muitas caras. Tantas quantas os morituros. Porque a sua, a verdadeira, é sempre igual à vida." $\mathrm{O}$ jovem tupi haveria de morrer no mesmo instante em que nasceria pela honra da sua morte e da tribo guerreira a que pertencia.

Temos aqui, em I-Juca Pirama, dois tipos de lágrimas, porque os índios choram, ora o "pranto ignóbil", ora o pranto de orgulho e alegria que "não desonra", que era natural do índio, porque as lágrimas faziam parte do ritual e das festas indígenas ${ }^{231}$. Para Coutinho ${ }^{232}$, este é o retrato do próprio Gonçalves, cujas lágrimas caíam por vezes como forma de consolação, umas em silêncio, e outras fictícias

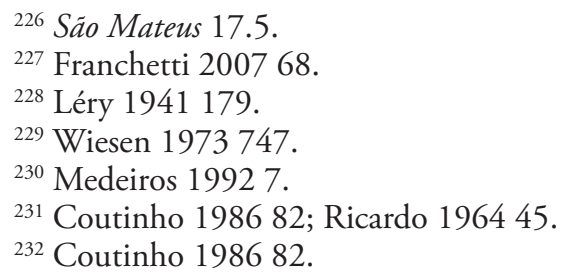


Para Ackermann ${ }^{233}$, I-Juca Pirama deve ser classificado como um canto heróico, sobretudo no grupo de composiçóes em que o heróico se funde com o sentimental, o que configura a antiepopeia em si.

De facto, Gonçalves Dias copiou o modelo grego de tragédia. No modelo engendrado, o sujeito do acto trágico deve ter em mente tudo aquilo que deve sofrer. O sacrifício é feito conscientemente. Conforme a afirmação de Lesky ${ }^{234}$, "Onde uma vítima sem vontade é conduzida surda e muda ao matadouro, não há impacto trágico." Nas tragédias gregas, todos os heróis que se encontram com o seu destino fatal causam antes um impacto. Citemos o caso da tragédia Ifigénia em Áulide de Eurípides: todo o drama se constrói em torno da necessidade do sacrifício versus o conflito interior de Agamémnon. Quando o rei toma consciência da impossibilidade de não ofertar a filha, sofre um novo dilema: convencer a esposa. Por isso, decide ludibriá-la com uma falsa oferta de casamento de Aquiles a Ifigénia. Agamémnon esquece-se, porém, de que a mãe jamais deixaria de acompanhar a filha neste momento tão ímpar, surgindo então novos dilemas no instante em que Aquiles se sente ludibriado por lhe terem sido ocultados os motivos da vinda da filha de Agamémnon. Por fim, o sacrifício é realizado, com lamentos da mãe que vê a filha perder a vida precocemente por causa de uma guerra que, até então, não lhe dizia respeito, mas também com os lamentos de Ifigénia que não vê alternativa a não ser submeter-se ao ritual; e os do pai, que se vê obrigado a realizar um sacrifício dessa natureza. A tragédia de Eurípides possui indiscutivelmente um impacto trágico de grande natureza.

Frye afirmaria ainda que até na Cristologia existe uma espécie de fuga ao destino, quando, em face da morte, vai ao Getsêmani e clama por socorro, as palavras: "Meu Pai, se é possível passe de Mim este cálice; todavia não seja como Eu quero, mas como Tu queres $^{235}$." Frye classific -as como "a sense of his exclusion, as a divine being, from the society of the Trinity ${ }^{236}$." Era desejo da Trindade o resgate da humanidade, porém apenas Cristo cumpria uma sentença. Diríamos que se sua morte não ocorresse, o desejo da Trindade não se realizaria, porém, ao fazê-lo sozinho, sente-se

${ }^{233}$ Ackermann 1964109.

${ }^{234}$ Lesky 199634.

${ }^{235}$ São Mateus 26.39.

${ }^{236}$ Frye 195736. 
excluído da Trindade. Em termos específicos, uma coisa é ser o Pai que contempla o filho perecendo por uma causa que é do interesse comum de ambos; outra é ser o próprio objecto de sacrifício, a questão que o aflige na hora da morte. É ser o único a pagar o preço em sangue.

O jovem Tupi torna-se semelhante ao Pharmakós. Segundo Frye, o Pharmakós ou Scapegoat ${ }^{237}$, «Bode Expiatório», exerceu uma influência muito grande na cultura hebraica. O ritual de expiação da culpa do povo era efectuado por um sacerdote:

Aarão apoiará as duas mãos sobre a sua cabeça do bode vivo e, nesta posição, confessará todas as iniqüidades dos filhos de Israel, todas as suas transgressóes e todos os seus pecados, fazendo-os assim cair sobre a cabeça do bode, que enviará para o deserto, levado por um homem designado para isso. $\mathrm{O}$ bode levará sobre si, todas as iniqüidades deles para uma região solitária e será abandonado nesse deserto ${ }^{238}$.

Porém, na cultura helénica o Pharmakós ganharia outra dimensão:

O Pharmakós is neither innocent nor guilty. He is innocent in the sense that what happens to him is far greater than anything He has done provokes, like the mountaineer whose shout brings down an avalanche. He is guilty in the sense that he is a member of a guilty society, or living in a world where such injustices are an inescapable part of existence 239 .

Entre os hebreus, o Scapegoat deveria ser o melhor de entre o rebanho, ao passo que entre os gregos, o Pharmakós era de baixa origem e maltratado por natureza ${ }^{240}$. O jovem Tupi torna-se o Pharmakós porque tem de morrer pela honra de sua tribo, e não há outro que o possa fazer - é o último sobrevivente. Não é culpado nem inocente, mas está inserido na categoria culpada, e por isso deve perecer.

A representação do sacrifício no poema I-Juca Pirama, em contrapartida, tem o objectivo de representar o costume indígena na sua originalidade, embora a antropofagia seja, na sociedade ocidental, prática de repúdio, sobretudo numa sociedade cristá,

${ }^{237}$ Frye 195741.

${ }^{238}$ Levítico 16.21-22.

${ }^{239}$ Frye 195741.

${ }^{240}$ Bremmem 1983303. 
onde tais práticas são observadas como frutos dos investimentos satânicos. Mas Gonçalves Dias quer enaltecer o índio e constrói a mais bela representação neste poema, obstruindo os elementos de sua própria crendice e dos ensinamentos de Anchieta - primeiro apóstolo católico em terras brasileiras - que, conforme ressaltou Bosi, transportou para o universo de Anhangá todos os actos indígenas condenáveis sob o ponto de vista cristão, hábitos costumeiros como: antropofagia, poligamia, embriaguez pelo cauim e inspiração dos fumos queimados nos maracás ${ }^{241}$.

No que toca à antropofagia, Bosi ${ }^{242}$ ressalta que o ritual de se alimentar do inimigo remetia, na realidade, para um bem substancial para a vida da comunidade, sendo uma acção de teor eminentemente sacral que dava a todos os que o celebravam uma nova identidade e um novo nome. A antropofagia, portanto, não pode ser compreendida fora da crença no aumento da força que se recebia pela absorção do corpo e da alma de inimigos em peleja honrosa ${ }^{243}$. A intenção poética de Gonçalves é apresentar uma aldeia selvagem e pujante, ainda não contaminada pela presença do homem branco, e o tema central é o fim de uma linhagem e a dispersão ou desgraça de uma nação ${ }^{244}$.

Embora seja controversa, e não cabe a nós investigar por que razão Gonçalves atribuiu valores Tupis aos Timbiras, torna-se necessário frisar que, ao analisarmos a afirmação de Alexander Von Humboldt ${ }^{245}$, de que a prática do canibalismo não se dava entre os índios mais atrasados, e sim entre os tecnicamente mais avançados (e que corresponde ao que Castillo ${ }^{246}$ observara entre os astecas, no México), só aí chegamos à conclusão do motivo porque Gonçalves Dias terá atribuído aos Timbiras os costumes antropofágicos.

$\mathrm{O}$ poema termina com os registos da memória de um velho Timbira. A memória constitui os media das sociedades arcaicas ou primitivas. A modernidade do terceiro milénio desconhece a memória, nos termos do verso gonçalvino ${ }^{247}$.

${ }^{241}$ Bosi 200167.

${ }^{242}$ Bosi 200167.

${ }^{243}$ Bosi 200169.

${ }^{244}$ Franchetti 200765.

${ }^{245}$ Apud Kothe 1997269.

${ }^{246}$ Apud Kothe 1997269.

${ }^{247}$ Coelho da Silva 2006163. 


\section{Tupá: o paradoxo de Gonçalves Dias}

"O homem branco, aquele que se diz civilizado, pisou duro náo só na terra, mas na alma do meu povo, e os rios cresceram, e o mar se tornou mais salgado porque as lágrimas da minha gente foram muitas."

Cibae Ewororo - ou Lourenço Rondon - índio Bororo, de Mato Grosso

A nostalgia é o tema central de toda a obra indianista de Gonçalves Dias. O poeta denomina-se "Cantor de um povo extinto.” A nostalgia, aliás, é o tema central de todo o lirismo gonçalvino. De entre os poemas de carácter nostálgico, poderíamos destacar o poema Canção do Exílio. É que, segundo Coutinho ${ }^{248} \mathrm{e}$ Ricardo ${ }^{249}$, a Canção do Exílio é um poema indianista.

O lirismo idílico de Gonçalves Dias, figurado no poema indianista Canção do Exílio, possui uma melodia que mais parece uma cançáo do que um poema, graças a certas palavras-chave, como é o caso do sabiá que nela gorjeia quatro vezes, por causa do "a”" de sabiá, com o sabor de vogal indígena, ao fim de cada instância em agudo ${ }^{250}$. Todavia, na imagem de saudade e exaltação da terra pátria, o optimismo que parece configura -se provém de um pessimismo. Conforme diria Coutinho ${ }^{251}$ : a saudade gonçalvina chega a ser indígena, tamanha é a sua ingenuidade. Mas também porque evoca o país das palmeiras, o Pindorama, onde canta o sabiá - passarinho triste que figura nos poemas indígenas uirachué, ou hoä-pyi-har.

Os índios sentiam saudade. $\mathrm{O}$ amado ausente é um tema indígena que constitui um dos refrãos dos poemas rudimentares do nosso selvagem. A divindade denominada Rudá era responsável por despertar ternura no coração dos homens e fazê-los voltar para a tribo ${ }^{252}$. Outra característica que faz da Canção do Exílio um poema tipicamente indianista é a sua semelhança com o poema

${ }^{248}$ Coutinho 198673.

${ }^{249}$ Ricardo 196422.

${ }^{250}$ Coutinho 198677.

${ }^{251}$ Coutinho 198679 .

${ }^{252}$ Coutinho 198679. 
Leito de Folhas Verdes, em que o poeta não empregou saudade no sentido português, como terá empregado nos poemas que não são indianistas. Embora alguns teóricos aleguem a existência da saudade, deve-se considerar que o poeta nem se referiu ao vocábulo. Nestes poemas, o que o rege é, de facto, a nostalgia ${ }^{253}$. Além disso, por mais portuguesa que seja a palavra, o exílio no Brasil é agravado pela soma de três exílios: o do índio, com saudade da taba; o do negro, com saudade de África; o do português, com saudade da metrópole. Enquanto a saudade portuguesa se baseia nas coisas que o tempo levou consigo, a brasileira é a poesia da distância e Gonçalves utiliza as duas no conjunto da sua obra: a saudade indianista representada pela distância física da pátria, e a saudade no sentido português, que não pertence ao indianismo ${ }^{254}$.

Quando observamos o conjunto da obra Gonçalvina, tida, por muitos teóricos, como o indianismo mais puro da literatura brasileira, surge um paradoxo em torno das divindades indígenas, porque o poeta, que táo bem soube representar a cultura indígena, modificou as crenças indígenas e os poderes dos deuses, se é que assim podem ser classificados

Para compreendermos o paradoxo gonçalvino, é mister que retomemos a Canção do Exílio:

\author{
Minha terra tem palmeiras, \\ Onde canta o sabiá; \\ As aves, que aqui gorjeiam, \\ Não gorjeiam como lá. (CE 1-4)
}

A indicação das palmeiras na terra de Gonçalves é uma referência ao Maranhão, porque, na maior parte do território brasileiro, não existem palmeiras com a mesma abundância que na terra do poeta. Já a referência "onde canta o sabiá" é uma inovação poética de Gonçalves Dias. O sabiá já havia sido empregado por Gonçalves de Magalhães em Suspiros Poéticos e Saudades, que para Coutinho ${ }^{255}$ não haviam produzido nenhum resultado poético semelhante ao sabiá gonçalvino. Porque Gonçalves de Magalhães empregou o sabiá em oposição ao rouxinol (o que se tornava muito importante numa hora de reivindicação nativista), o sabiá passava a ter um argumento ideológico de nativismo, como o indígena em Gonçalves Dias.

A inovação de Gonçalves é que o sabiá que frequenta as

${ }^{253}$ Coutinho 198679.

${ }^{254}$ Coutinho 198680.

255 Coutinho 198677. 
palmeiras é o único que não canta: o sabiapoca. O que canta é o "laranjeira", o sabiapiranga; é também o sabiaúna; e estes não cantam em palmeiras ${ }^{256}$. Nesse ponto, Gonçalves de Magalhães teria sido mais exacto que Gonçalves Dias, porque o seu sabiá cantava em laranjeira, e não na palmeira.

Gonçalves Dias muniu-se da sintaxe poética para fazer o sabiá cantar na palmeira, e muito legitimamente. Tanto que o sabiá de Gonçalves de Magalhães, cantando no lugar correcto - na laranjeira - parou de cantar, ou foi silenciado pelo esquecimento; já o de Gonçalves Dias gorjeia até hoje. Ninguém o conseguirá calar. Isto refere-se ao que Coutinho ${ }^{257}$ denomina de "Verdade poética”, que não precisa ser comprovada. Tal como Gonçalves Dias disse no mesmo poema:

Nosso céu tem mais estrelas,

Nossas várzeas tem mais flo es, (CE 5-6)

São verdades poéticas que ninguém irá redarguir estatisticamente. As verdades poéticas emparelham com os mitos, ou são mitos elas mesmas, e não há lógica nem filologia competentes para as reduzir pela análise. Poder-se-ia apelar à alegoria: o canto do sabiá, voz da saudade, já que este pássaro melancólico é a voz da nossa paisagem, na palmeira, imagem da pátria. Certo surrealismo, plausível numa hora de exacerbação ou de amargura desfiguradora, causada pelo sentimento de ausência - poderia ser invocado ${ }^{258}$.

A natureza errou, evidentemente; havia dado ao que não canta o que devia ter dado ao que canta: a atitude, a elevação que o canto obtém quando cantado na palmeira e não na laranjeira... Vem o poeta e corrige o que estava errado na natureza; era um direito seu $^{259}$.

A inovação poética é tema central em toda poesia de Gonçalves Dias: em Tabira, o poeta invertera o resultado da guerra entre os Tabajaras e Potiguaras; em I-Juca Pirama, o poeta mudara o tradicional canto de morte do prisioneiro; e na Canção do Exílio o poeta fez cantar o sabiá que não canta. Porém, de todas estas verdades poéticas, uma acabaria por se tornar notória, porque

${ }^{256}$ Coutinho 198677.

${ }^{257}$ Coutinho 198678 .

${ }^{258}$ Coutinho 198678 .

${ }^{259}$ Coutinho 198678 . 
não é exclusiva de um só poema, mas de toda a obra indianista: Tupã e Anhangá.

Podemos compreender esta problemática a partir do que ressalta Angione $\operatorname{Costa}^{260}$. As raças brasílicas avançaram do totemismo à procura de formas mais abstractas da ideia de Deus. Tupã era um ser misterioso e desconhecido, mas que se manifestava na luz, nas claridades do céu, na fulguração dos relâmpagos, no fogo, no trovão, no sol. Inferiores a Tupã, existiam vários deuses ou génios, todos propiciadores do bem, não se conhecendo nenhum que fosse a encarnação do mal, o equivalente a Satanás. Embora Angione $\operatorname{Costa}^{261}$ não declare o nome de Gonçalves Dias, referese ao cantor dos Timbiras, pelo que se subentende ser o poeta maranhense, uma vez que é o maior poeta deste género a cantar os Timbiras. Angione Costa refere-se ao caso de Anhangá, tido no poema como a prefiguraçáo do mal, traçando um paralelismo com a teogonia cristá; ainda assim, concentra-se nele uma forma de poder maléfico muito inferior ao do anjo ebelado da Bíblia.

Gonçalves ignora todos os deuses do panteáo indígena e opta apenas por Tupã e Anhangá. Os três maiores deuses deste panteão eram: Coaraci ou Guaracy (Sol), Jaci (Lua) e Rudá (Deus do amor). Abaixo destes três encontrava-se uma categoria menor, que a estes estava subordinada. Ligado a Coaraci estava Iapurú, que comanda o destino dos pássaros e tem o dom de atrair a felicidade com o seu canto; Caapora, que comanda os destinos dos animais da flo esta; Uiara, que comanda o destino da vida aquática; Macachera, que protegia os guerreiros em campanha e guiava as expediçóes ${ }^{262}$. Ligados a Jaci estava Mboitatá, que protege os campos contra incêndios; Curupira, amigo das flo estas; Saci-pererê, guarda das capoeiras da vizinhança das tabas $^{263}$. E a Iara, senhora das águas ${ }^{264}$. Ligados a Rudá estava Cairê, lua cheia; Caiti, lua nova; Mboia, guarda das donzelas ${ }^{265}$. E Jurupari, espírito do $\mathrm{mal}^{266}$. No entanto, os índios não prestavam culto a nenhuma divindade, o que é substancialmente diverso do modelo de religiáo do Velho Mundo.

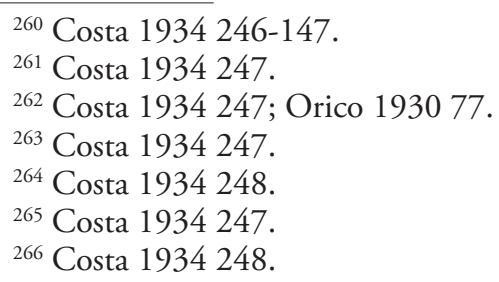


Segundo Cardim ${ }^{267}$, por não terem nome próprio e natural para Deus, os Jesuítas passaram a chamá-lo Tupã, porque nos braços dessa divindade estava a responsabilidade pelos trovóes e relâmpagos. E foi este que lhes deu as enxadas e os mantimentos. Além disso, cedo se aperceberam do grande temor que assaltava os índios perante uma tempestade de trovóes e relâmpagos. Cardim $^{268}$ ressalta ainda que os índios possuíam medo do demónio, o qual chamavam Curupira, Taguaigba, Macachera, Anhangá. De entre estes, porém, o mais temível era Anhangá, motivo pelo qual os Jesuítas o usaram para representar a imagem de Satanás. Mas, para Orico ${ }^{269}$, a atribuição ficou comprometida, porque Anhangá náo possui os mesmos atributos que o demónio, nem mesmo existia entre os índios uma divindade capaz de substituir Santanás. Gonçalves Dias também escolheu Anhangá como principal demónio atormentador dos indígenas.

De um lado, Anhangá, o reino do mal, que assume o código de uma ameaça anti-divina, semelhante ao Demónio hipertrofiado das fantasias medievais. Do outro, Tupá, o reino do bem, com virtudes criadoras e salvíficas, em aberta contradição com o mito original, no qual lhe atribuíam precisamente os poderes aniquiladores do raio ${ }^{270}$ e também do fogo ${ }^{271}$.

De acordo com Melatti ${ }^{272}$, Tupã é como um demónio que controla o raio e o trováo, podendo até provocar a morte e destruição. Mas em nenhum momento Tupã fora considerado pelos índios Tupis como o principal entre os seres sobrenaturais ${ }^{273}$.

As alteraçóes de Gonçalves no culto indígena, a substituição dos "deuses" e "demónios" pela dupla antitética Tupã e Anhangá são causa de diversas controvérsias. Por que teriam feito os Jesuítas, nos primeiros anos da colonização, uma alteração semelhante, usando os mesmos pseudónimos indígenas para as divindades católicas? Isto parece dar prosseguimento à mesma ideia que consagrou o elemento indígena. Gonçalves parece deixar transparecer que o índio só é escutado para dizer o que o europeu queria escutar dele ${ }^{274}$. Enfim, o índio de Deprecação

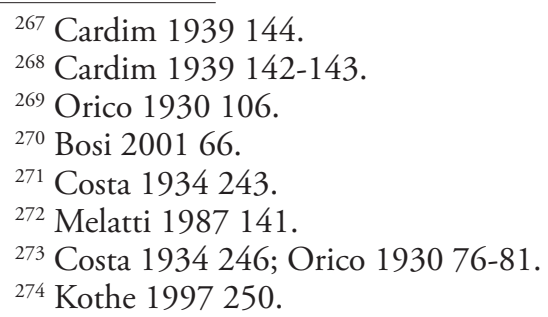


demonstra que, apesar da destruição do colonizador, os Jesuítas teriam cumprido a sua missão, antes de serem expulsos do Brasil durante a era pombalina.

Seria incoerente, portanto, julgar a modificação de Gonçalves apenas por este poema, já que nele está mais visível esta transformação. Percebemos que, embora Gonçalves tenha aceitado as mudanças de pseudónimos que os Jesuítas propuseram, o poeta reivindica para o índio o direito das divindades, porque enquanto os Jesuítas fundiam a imagem de Deus em Tupã e a de Satanás em Anhangá, em Gonçalves eles são distintos. Os seres sobrenaturais do índio são diferentes dos seres naturais do europeu. Têm as mesmas convençôes, seguem as mesmas pragmáticas, mas não são os mesmos. A mudança que Gonçalves fez, na realidade, é mais uma reivindicação nativista do que uma alteração da mitologia original. Ou seja, usou o que já vinha sendo usado pelos cronistas, mas, desta vez, em prol do seu objectivo poético.

\section{É Tabira - cruel, inimigo,}

Já nem crê, renegado, em Tupã. (T 75-76)

Tabira tinha contraído aliança com os portugueses. Tinha-se convertido ao cristianismo. A referência com que os Potiguaras citam o inimigo, a forma como havia renunciado a Tupá porque nele não cria, causa uma discórdia em relação à imagem que os Jesuítas forneciam de Tupá. Para estes, renunciar a Tupã significa a renunciar a Deus, à religiáo dos portugueses. Para os Potiguaras, o facto de Tabira se ter convertido ao cristianismo denotava que teria renunciado a Tupã. Daí concluímos que o Tupã gonçalvino não é o mesmo que o jesuítico. Diríamos que, pretensiosamente, Gonçalves fi era uma reivindicação nativista, e que para isso foi necessário utilizar o mesmo plano cristão, mas a partir da óptica indígena.

Antes de analisarmos Deprecação, julgo necessário estabelecermos a pragmática gonçalvina do panteão indígena, para que risquemos todos os pressupostos equivocados sobre a teogonia gonçalvina. Por que, enfim, Gonçalves fez a reivindicação nativista semelhante à que Gonçalves de Magalhães fi era com o sabiá? O que não se pode deixar de perceber é que, embora o poeta optasse por Anhangá e Tupá como representantes legítimos, ele não desprezou as crenças indígenas. $\mathrm{O}$ poeta que criou o mito do sabiá que canta nas palmeiras, num projecto de reivindicação 
mítica, desconstrói a pragmática jesuítica e restabelece-a numa nova pragmática indígena.

Segundo Bosi ${ }^{275}$, os índios não prestavam culto organizado a deuses e heróis, como faziam gregos e romanos. Angione Costa ${ }^{276}$ ressalta, ainda, que entre eles não havia crença num ser supremo. Porém, no início de Os Timbiras, o poeta estabelece a crença do povo extinto em Tupã:

Os ritos semibárbaros dos Piagas,

Cultores de Tupã, a terra virgem

Donde como dum trono, enfim se abrira

Da cruz de Cristo os piedosos braços; (OT i.1-4)

Nota-se que o termo "Cultores de Tupã” não compromete a verdade histórica, porque de facto os índios conheciam Tupã e temiam os males que este poderia causar à sua tribo. A alusão de que Tabira não acreditava em Tupã advém do facto dos Potiguaras pertencerem a esta raça extinta de "cultores de Tupá." Desta maneira, o poeta vale-se da poesia para estabelecer uma verdade poética. Mas, ao reivindicar Tupá como deus indígena, o poeta entrelaça-o com características indígenas do deus, porque os Jesuítas se tinham valido apenas do pseudónimo, ao passo que as suas características eram peculiarmente bíblicas.

\footnotetext{
"Tupã sorri-se lá dos astros,

- Diz o chefe entre si, - lá, descuidosos

Das folganças de Ibaque, heróis timbiras

Contemplam-me, das nuvens debruçados:

E por ventura de lhes ser eu filh

Enlevam-se, e repetem, não sem glória,

Os seus cantores d'Itajuba o nome. (OT 1.246-252)
}

A referência é cópia da crença indígena. O Ibaque é um lugar indefinido e ilimitado onde se movem os astros. Onde Tupã e os deuses indígenas habitavam, para lá iam as almas dos mortos. Cardim $^{277}$ afirma que os índios detinham o conhecimento de que possuíam alma e de que esta era imortal. Diziam que, depois de mortos, iam para uns campos de muitas figueiras, ao longo de um formoso rio, e todos juntos não faziam outras coisas senão

\footnotetext{
275 Bosi 200168.

${ }^{276}$ Costa 1934242.

277 Cardim 1939142.
} 
bailar. Do Ibaque era possível que os heróis mortos enxergassem os feitos de suas tribos, e deles se orgulhassem.

- "Tupã, que tudo podes,

Orava Ogib em lágrima desfeito, (OT 2.447-448)

Eis uma inovação poética de Gonçalves. Os índios não prestavam oraçóes aos deuses. O máximo que faziam era respeitá-los e sentir extremo temor pelo mal que podiam causar. Porém, a imagem de Ogib orando em lágrimas, clamando por Tupá, torna-se uma evocação da oraçáo de Job quando clama com palavras semelhantes: "Sei que podes tudo ${ }^{278}$." Náo seria a única vez que o poeta evocaria os clamores do patriarca bíblico para os índios brasileiros.

Não decide Tupã humanos casos,

Quando imprudente e cego o homem corre

D'encontro ao fado seu: não valem sonhos,

Nem da prudência meditado aviso

Do atalho infausto a desviar-lhe os passos! (OT 4.344-348)

Tupã não interfere nos casos humanos quando estes, cegos, correm ao encontro do destino, porque, nestes casos, os sonhos náo valem, nem o aviso prudente para desviar os passos. Esta inovação poética contrapóe Tupá ao deus hebreu, porque Deus mandou Noé ${ }^{279}$ apregoar a destruição do mundo, exigindo o arrependimento dos povos, a fim de evitar a destruição. Porém, a pregação fora em vão, o povo não se arrependeu, e a destruição foi necessária. A pregação da crença do final apocalíptico do mundo, por exemplo, afirma que quem crer será salvo e quem não crer será condenado ${ }^{280}$, ou seja, o Deus hebreu avisa os seres humanos, independentemente da sua prudência ou imprudência.

A inovação gonçalvina constrói o mito da protecção de Tupã, que era o responsável pelos sonhos:

Tupã vos olhe, e sobre vós do Ibaque

Os sonhos desçam, quando o orvalho desce! (OT 2.119-120)

A respeito da singela ideia religiosa que os caracterizava, tinham noção de Ente Supremo, cuja voz se fazia ouvir nas

${ }^{278}$ Job 42.2 .

${ }^{279}$ Génesis 6.13-22; 7; 8.

280 São Marcos 16.15-16. 
tempestades - Tupã-cinunga, ou "o trovão", cujo refle o luminoso era Tupäberaba, ou "relâmpago". A crença de que os portugueses eram filhos de Tupá nasceu em virtude das armas de fogo. $\mathrm{O}$ estrondo que estas armas possuíam assemelhava-se aos trovôes, cuja obra da natureza era a representação principal do deus indígena :

Hospedes são, nos diz; Tupã os manda:

Os filhos de tupâ serão bem vindos, ( T 2.251-252)

Gonçalves, enfim, atribui a Tupã uma característica puramente indígena: a dos males que o deus poderia causar. $\mathrm{O}$ barulho provocado pelo trovão era a representaçáo da fúria da divindade. Os relâmpagos eram sinais vitais do deus encolerizado. Portanto, não passava de um efeito, cuja causa o índio desconhecia e, por isso mesmo, temia. $\mathrm{O}$ poderio de Tupã causava mais males às tribos do que bem. Será por isso que, no poema I-Juca Pirama, o velho Tupi tanto receia os males que de Tupã ainda haveriam de vir.

A quem Tupã tamanha dor, tal fado

Já nos confins da vida eservara, (JP 398-399)

O furor de Tupã era representado no trovão e no relâmpago, o poeta figura o relâmpago num elemento comum aos indígenas, a seta. A seta de fogo que corria o céu na direcção do ocaso.

"Tupã! que mal te fiz, que assim me colh

Do teu furor a seta envenenada?

Com voz chorosa e trêmula clamava. (OT 3.488-490)

O clamor de Ogib muito se assemelha às palavras de Job. A oração acima é símile da resposta que Job deu a Elifaz: "Porque as setas do Todo-Poderoso estáo cravadas em mim, e o meu espírito absorve o veneno delas ${ }^{281}$." O drama de Job é tido como um dos mais belos da antiguidade, por isso seria pertinente, ao cantor de uma raça extinta, usar tal símile. Gonçalves fá-lo pela reivindicação, na procura de legitimar a religiáo indígena, contudo sem a misturar com o cristianismo.

Quanto a Anhangá, Gonçalves nomeia-a com maior destaque no poema Deprecação. O recurso poético menos frequente deste ${ }^{281}$ Job 6.4. 
espírito da flo esta explica-se pelo facto de ser uma divindade pouco alterada, visto que o poeta náo lhe atribui poderes táo austeros como os de Satanás.

“O poder de Anhangá cresce co’a noite;

Solta de noite o mau seus maus ministros:

Caraibebes na flo esta acendem

A falsa luz, que o caçador transvia. (OT 2.88-91)

Grande era o número de indígenas que tinham parentesco com um ser superior, a que chamavam de "Caraibebes", que os Jesuítas traduziam por "anjos". Gozavam de uma vida avantajada, esses que se inculcavam serem ministros dos Caraibebes. Recebiam os melhores frutos da terra e as mais cobiçadas caças que fossem abatidas pelas cercanias. Quando um guerreiro partia para a guerra, era honrado com um sopro do Caraibebe, para que náo morresse em combate. Entretanto, se algum caía morto na batalha, havia a desculpa de que se tornara indigno da bênção do "Caraibebe". Deste modo, esses pajés tornaram-se infalíveis, com prestígio inabalável entre os seus crentes.

A referência de Gonçalves aos Caraibebes, porém, baseia-se na descrição destes espíritos da flo estas que eram capazes de enganar o índio; esta é uma das poucas referências aos seres protectores da flo esta. A maior delas seria no poema Mãe D’água, porque Gonçalves se restringira em Anhangá e Tupá.

Já foi dito que os índios não viam a noite com bons olhos, e por isso Gonçalves descreve o negro da cor da noite, porque estes eram capazes de se submeter à escravidão quando eram açoitados. Portanto, a escravidão era o mal maior que se causava ao índio. Junto com a noite crescia o poder de Anhangá, e por isso é que em $O$ Canto do Piaga, Anhangá vedava-o de sonhar, já que o sonho era fruto nocturno.

Esta noite - era a lua já morta -

Anhangá me vedava sonhar; (CP 5-6)

Na poética de Gonçalves, Anhangá opõe-se a Tupã raríssimas vezes. Tupá é responsável por enviar sonhos à noite, e Anhangá vê o seu poder crescer com a noite e, por isso, é capaz de vedar o Piaga de sonhar. O poder destruidor de Anhangá é notório no poema Deprecação. 
O poema Morro do Alecrim estabelece o elo entre o presente (tempo da cidade) e o passado remoto (tempo da primeira instalação portuguesa no Maranhão). Era um fantasma, um vulto errante de índio que surgia pela alta madrugada e pronunciava a invocação aos deuses, na qual lamentava a destruição da sua tribo $^{282}$. Quando Gonçalves Dias reuniu os livros de poesia para uma publicação conjunta, em 1857, alterou a secção de Poesias Americanas, tirando Morro do Alecrim e em seu lugar colocando Caxias e Deprecação.

Deprecação é, com algumas modificações, a parte final do Morro do Alecrim, cujas estrofes haviam sido transcritas por Herculano como exemplo de poesia americana, enquanto Caxias, embora originalmente tenha quatro estrofes, três são partes de Morro do Alecrim $^{283}$. Para Franchetti ${ }^{284}$, esta alteração pode ter dois motivos, primeiro por talvez corresponder ao elogio do escritor português, já que Deprecação torna-se um poema exclusivamente indianista. Mas é possível que o desmembramento tenha outros motivos, se considerarmos o que ficou fora e que foi ac escentado.

Tendo em vista a desintegração do poema, não é preciso analisar Morro do Alecrim, cabendo analisar apenas a parte indianista que corresponde às palavras de um fantasma, de um vulto errante do índio que surge no alto da madrugada e pronuncia a invocação dos deuses, lamentando a destruiçáo de sua tribo, expressa no poema Deprecação.

Tupá, ó Deus grande! cobriste o teu rosto

Com denso velâmen de penas gentis;

E jazem teus filhos clamando vinganç

Dos bens que lhes deste da perda infeliz! (D 1-4)

A imagem de Tupá, com o rosto coberto por um denso véu de penas, assemelha-se aos cocares usados pelos indígenas nas suas festas e, também, pelo chefe da tribo em ocasiôes necessárias. Porém, enquanto Tupá está com o rosto coberto de um véu de penas, os seus filhos jazem clamando pela vingança do deus protector. Porque os bens que obtiveram deste deus tinham-nos perdido numa guerra em que foram vencidos, embora sem o combate honroso, conforme seria considerado glorioso.

${ }^{282}$ Franchetti 200756.

${ }^{283}$ Franchetti 2007 55-56.

${ }^{284}$ Franchetti 200756. 
A partir da imagem de Tupã com o rosto coberto, o poeta guiar-nos-á pelas afliçóes que acometeram as tribos nativas. De acordo com Moisés ${ }^{285}$, Gonçalves Dias é o "antípoda do poeta cerebrino ou reflexi o", porque nele a emoção é tudo, mas a emoção é guiada pela inteligência, pelo bom gosto ou pelo decoro.

Tupã, ó Deus grande! teu rosto descobre:

Bastante sofremos com tua vingança!

Já lágrimas tristes choraram teus filho

Teus filhos que choram tão grande mudança. ( $\left.\begin{array}{ll}\mathrm{D} & -8\end{array}\right)$

Estas lágrimas vieram em virtude dos sofrimentos constantes, da grande mudança, e, porque as tribos haviam sucumbido da honra das batalhas vencidas, para a desonra da derrota sem combate. O velho clama por Tupã, para que descubra o rosto, a fim de que olhe para o seu povo e deles retire a sua ira e vingança. Os clamores direccionados a Tupá tornam-se bastante parecidos com as oraçóes do patriarca Job e dos salmos de Asaf ${ }^{286}$, e assemelham-se também a muitos outros discursos bíblicos.

A diferença entre os cânticos de Asaf ou os monólogos de Job e o clamor do velho Tupi, é que neste há a presença de um ser causador dos males. Porém a curta referência a Anhangá e a atribuição das dores principalmente ao descaso de Tupá pelo seu povo, sugere enfim que Tupá é superior a Anhangá; ou que no mínimo é o protector do povo, ao passo que Anhangá é o inimigo. Portanto, as preces surgem em virtude do abandono do deus protetor. Tupã seria, pois, o símbolo personificado da ideia da Tribo, e Anhangá o símbolo das forças demoníacas da violência e da destruição, à semelhança de Júpiter que é o símbolo personificado da ideia de Roma, e Juno o símbolo de forças demoníacas da violência e destruição. Júpiter é a organização que contém estas forças e mantém o equilíbrio universal. É também o equilíbrio entre a luz e a escuridão, entre a mente e a emoção, entre a ordem e o caos, que invade constantemente o cosmos, a alma e a política.

Anhangá impiedoso nos trouxe de longe

Os homens que o raio manejam cruentos,

Que vivem sem pátria, que vagam sem tino

Trás do ouro correndo, voraces, sedentos. (D 9-12)

${ }^{285}$ Moisés 1989 34-35.

${ }^{286}$ Os Salmos 72-74. 
Os maus, os efeminados e os covardes consumiam-se na danação eterna. Anhangá era responsável por atormentar aqueles que não haviam vivido de acordo com os bons costumes, que não tivessem mostrado valor nas guerras, ou aprisionado numerosos inimigos, sacrificand -os ritualmente ${ }^{287}$.

Mas, pela primeira vez na poesia de Gonçalves, e faz jus dizer que é a única também, é Anhangá o responsável pela chegada dos portugueses às terras indígenas, conforme estava arreigado no mito popular, pois na maioria das vezes (e é o que o poeta faz transparecer na epopeia Os Timbiras), os portugueses eram enviados por Tupá, porque se assemelhavam ao Deus, porque eram capazes de produzir o barulho do trovão. Porém, o poeta, numa atitude poética singular, assemelha Anhangá a Satanás, enviando homens que manejam o raio, que atrás de ouro correm vorazmente.

$\mathrm{Na}$ parte seguinte, o poeta segue descrevendo a atitude voraz dos homens que manejam o raio e que foram enviados por Anhangá. Uma controvérsia de nível pragmático, porque o que sugere o poeta é que as forças do mal se haviam sobreposto às forças do bem, como se, enfim, Anhangá tivesse descoberto o domínio dos raios e delegado aos portugueses, a fim de que estes invadissem a terra dos cultores de Tupã.

E a terra em que pisam, e os campos e os rios

Que assaltam, são nossos; tu és nosso Deus:

Por que lhes concedes tão alta pujança,

Se os raios de morte, que vibram, são teus? (D 13-16)

Quando Eneias parte de Cartago abandonando Dido, chama para si a responsabilidade do suicídio da rainha. Todavia, o herói brada «foi contra vontade». Protesta, mas obedece, condenando uma inocente, condenando o seu amor e uma parcela da própria descendência. Medeiros ${ }^{288}$ deixa algumas perguntas sobre este episódio: "Que deuses são estes que oprimem inocentes? Que deuses são estes que se alimentam de sangue e de dor, como o ventre de Moloc dos corpos das crianças?" Depois de Dido será Palinuro, Miseno, Euríalo, Niso, Palante, Lauso, Camila, Turno e Marcelo. Existe uma relação intrínseca entre o facto e os

${ }^{287}$ Abbeville 1945 252; D’Evreux 1929 294; The et 1944 261; Fernandes 1989164.

${ }^{288}$ Medeiros 199216. 
deuses. Em Eneida este é um detalhe ainda mais visível do que nas epopeias gregas. Todavia, é destas que herdou a concepção do destino e os deuses ${ }^{289}$. Já o índio de Deprecação conhece o seu Deus. Os rios, as terras são nossas e tu és o nosso Deus. A pergunta centra-se: por que teria Tupã permitido que os inimigos enviados de Anhangá tivessem tão alta potência, se os raios de morte, que os filhos de Anhangá manejavam, lhe pertenciam? $\mathrm{O}$ que o índio ainda não percebera é que Tupá havia perdido o domínio do raio. $\mathrm{O}$ seu rosto estava coberto com um denso velâmen de penas, para náo ver os seus filhos consumirem-se na danação dos filhos de Anhangá

De facto, as ideias da religiáo no original podem ser vistas como uma espécie de estrutura figurati a, que designa e ordena a narrativa clássica, e isto direcciona as questóes que vão sendo apontadas $^{290}$.

Basicamente os lusos tomaram as terras, os rios, as mulheres índias ${ }^{291}$. O poema Marabá seria um retrato desse acontecimento cuja revelação pauta-se na condição dos integrantes das tribos que, pela presença do estrangeiro, sofreram alteraçóes na pureza da raça - de um lado o colonizador português e do outro o elemento indígena feminino - procrastinando até destruir-se completamente, porque não houve uma alteração no luso, mas sim no indígena ${ }^{292}$.

Essencialmente o clamor do velho índio é a angústia generalizada em função da destruição de sua tribo. Para Bosi ${ }^{293}$, isto acontece porque o sujeito do discurso lírico romântico parece só ter condiçóes de subsistir quando lança mão de uma dimensão temporal: no passado da poesia nostálgica, no futuro da poesia utópica. Mas fechado na sua imanência, e na medida em que a natureza deixou de ser a sua grande testemunha, ele cai na angústia da finitude, e as suas figuras descolam do mito da queda.

Teus filhos alentes, temidos na guerra, No albor da manhã quão fortes que os vi! A morte pousava nas plumas da frecha, No gume da maça, no arco Tupi! (D 21-24)

\footnotetext{
289 Williams 19833.

${ }^{290}$ Williams 19833.

${ }^{291}$ Kothe 1997222.

292 Kothe 1997223.

${ }^{293}$ Bosi 1978248.
} 
Desta forma, o velho índio sente nostalgia de um tempo em que os filhos de Tupã eram temíveis na guerra e a morte estava nas plumas das flechas, na ponta do tacape, no arco Tupi. Neste clamor, relembrando o passado glorioso da tribo pujante, e a forma como foram surpreendidos, o índio não acreditava num futuro utópico, mas clama por um futuro, que sucederá caso, no presente, Tupã resolva tirar diante de si o denso velâmen de penas que lhe cobre o rosto impedindo de ver a morte dos seus filhos

Segundo Ackermann ${ }^{294}$, "por toda poesia passa, como um fio vermelho, uma ligeira queixa contra Tupã” e, por detrás do velho centenário, estava a figura do próprio Gonçalves Dias ${ }^{295}$. O poema foi escrito por um homem que não tinha apenas uma preocupação literária. $\mathrm{O}$ objecto da sua arte era a gente e terra do Brasil, mas a sua simpatia surge por ser o porta voz da raça a que estava ligada por sangue ${ }^{296}$.

E hoje em que apenas a enchente do rio

Cem vezes hei visto crescer e baixar...

Já restam bem poucos dos teus, qu'inda possam

Dos seus, que já dormem, os ossos levar.

Teus filhos alentes causavam terror,

Teus filhos enchiam as bo das do mar,

As ondas coalhavam de estreitas igaras,

De frechas cobrindo os espaços do ar. (D 25-32)

Os filhos de Anhangá causam uma desgraça tão profunda no seio da tribo Tupi, que Sodré ${ }^{297}$ denomina-a de destruição dos valores que os indígenas haviam conseguido elaborar - o esmagamento cultural. Mas a destruição dos valores indígenas, entre eles o culto a Tupã, também se reflecte no seio da flo esta. Conforme o poeta testemunha, os bem poucos que restaram da tribo Tupi já haviam deixado de praticar os costumes da tribo; já não caçavam nas flo estas frondosas.

A referência coincide com o surgimento das cidades, presumindo-se que, à semelhança do que estava em Morro do Alecrim, o poeta se referisse ao crescente número de índios que trocaram a vida na aldeia para servirem de escravos aos

${ }^{294}$ Ackermann 1964112.

295 Ackermann 1964111.

${ }^{296}$ Ackermann 1964112.

297 Sodré 1969265. 
portugueses, nas construçóes civis das cidades, garimpando nas minas de ouro, nos canaviais nordestinos, nos mais diversos tipos de trabalhos a que o negro devia servir aos portugueses. Um número de índios se viram obrigados a caminhar pelo mesmo via.

Já hoje não caçam nas matas frondosas

A corça ligeira, o trombudo quati...

A morte pousava nas plumas da frecha,

No gume da maça, no arco Tupi! (D 33-36)

Quando os portugueses chegaram ao Brasil, firmaram paz com as tribos locais. Inicialmente os portugueses estabeleceram apenas a troca de mercadorias, pequenas bugigangas, quinquilharias em troca de pau-brasil, embora ao longo da história, muitos teóricos tenham criticado esta permuta, justificando que o valor da madeira era bastante superior às quinquilharias, tais como espelho, machados, facas, enxadas, e armas de fogo. Todavia, deve ser considerado o valor cultural desta troca, porque o valor das quinquilharias europeias era realmente baixo, mas a verdade é que o pau-brasil existia em abundância, e não havia motivos para que os índios se mantivessem longe de produtos que lhes facilitariam o dia-a-dia, para viver com madeiras que não tinham tanto valor, quanto os referidos objectos. Mas aquilo que lhes trouxe benefício e facilidade no dia-a-dia, também lhe trouxe a morte.

O Piaga nos disse que breve seria,

A que nos infliges c uel punição;

$E$ os teus inda vagam por serras, por vales,

Buscando um asilo por ínvio sertão! (D 37-40)

Quando as primeiras desgraças acometeram os povos indígenas, os Piagas profetizaram que seriam breves, mas o velho centenário lamenta-se, porque os anos passaram e, no entanto, os Tupis continuavam a vaguear pelas serras, pelos vales, procurando abrigo no impérvio sertão.

Tupã, ó Deus grande! descobre o teu rosto:

Bastante sofremos com tua vingança!

Já lágrimas tristes choraram teus filhos

Teus filhos que choram tão grande ta dança. (D 41-44) 
Auerbach $^{298}$ observa uma singularidade entre o relato do sacrifício de Isaac e as narrativas de Homero, porque partindo da matriz homérica ficamos perplexos e perguntamos: "Onde estão os dois interlocutores?” Deus deve vir de algum lugar, deve irromper de alguma altura ou profundeza no terreno, mas nada disso é dito, ele não aparece como Zeus ou Poséidon que estava na Etiópia, regozijando-se com um holocausto. Nada sabemos, nem mesmo as razóes que o levaram a tentar Abraão. Não há uma assembleia como entre os deuses gregos e latinos.

No poema Deprecação, Tupã assume as convenções do deus hebreu, porque, ao contrário do que acontece em Os Timbiras, não temos noção de onde é que está Tupá. Sabemos apenas, por intermédio do poeta, que um velho centenário dirige as suas preces ao deus. Não há uma prova histórica de que os índios dirigiam prece a Tupá, mas estava comprovado que a responsabilidade da destruição era daqueles que dominavam os raios; portanto, o dono dos raios era Tupã, o que o tornava responsável pela destruição dos povos. Lesky ${ }^{299}$ observaria que "Somente o voltar-se para Deus pode dar segurança ao homem". Nesse ponto, o poema Deprecação está engendrado no modelo trágico do cristianismo, "aquilo que é sofrido até a destruição física pode encontrar, num plano transcendente, seu sentido e, com ele, sua solução ${ }^{300}$."

Todas as vezes que Israel se encontrava num período de prosperidade, no meio das alianças com as naçóes vizinhas, os israelitas absorviam os deuses vizinhos na sua cultura, tal como fi era com Moloque, Astarote, Baal, etc. Porém, ao caírem em ruína, abandonavam os deuses vizinhos e voltavam-se para Deus. Há uma diferença singular entre os deuses vizinhos e Deus, porque os deuses vizinhos eram físicos. A adoração de Astarote, por exemplo, era simples, porque a fertilidade era algo comum, os campos produziam a semente plantada, as mulheres procriavam, os animais pariam suas crias; porém, quando uma peste assolava os campos judeus, matando certas espécies de semente, quando certas doenças impediam o crescimento dos filhos, ou matavam as criaçóes, ou o gado no pasto, etc., a figura de Astarote deixava de ter importância. Somente uma explicação metafísica era a solução nestes casos. Daí o voltar-se para Deus ${ }^{301}$.

\footnotetext{
${ }^{298}$ Auerbach 1982 5-6.

${ }^{299}$ Lesky 199631.

${ }^{300}$ Lesky 199641.

${ }^{301}$ Lesky 199631.
} 
Engendrado neste modelo, Tupã adquire características metafísicas, perde o poder dos raios consumidores para os filhos de Anhangá. A cobertura do rosto de um denso véu de penas refere-se justamente ao desaparecimento do poder do deus protector das tribos Tupis. A transcendência de Tupã deve-se à perda da sua parte física.

A suprema infelicidade do velho Tupi, as suas últimas palavras tornam-se a evocaçáo da decisão de Dido que "nas últimas palavras que profere diagnostica com lucidez a causa da sua suprema infelicidade 302 ." Num último arcar de esperança, o velho clama novamente para que Tupá descubra o rosto, a fim ver as desgraças que acometiam os seus filhos

Descobre o teu rosto, ressurjam os bravos,

Que eu vi combatendo no albor da manhã;

Conheçam-te os feros, confessem vencidos

Que és grande e te vingas, qu'és Deus, ó Tupā! (D 45-48)

As divindades da Eneida possuem poderes limitados. O próprio Júpiter náo consegue livrar Sarpédon da morte. As divindades sofrem por não saberem se conseguiráo levar a cabo seus intentos ${ }^{303}$. Mas Tupá náo sofre, porque perde alguns dos seus poderes físicos ou, pelo menos, deixa de ser o único a controlálos. O sofrimento cai nos adoradores que viram os poderes de Tupã relegados aos filhos de Anhangá.

Os heróis clássicos, apesar das peripécias que enfrentavam, estavam, ao longo do caminho, amparados por uma força divina. Odisseu é o protegido de Atena ${ }^{304}$ e Eneias é amado por Vénus ${ }^{305}$. Já a causa maior do pessimismo em Deprecação é justamente a falta de um protector para os índios, porque o protector do povo Tupi estava com o rosto coberto de muitas penas, impedindo-o de se aperceber da aflição dos seus filho

$\mathrm{O}$ pessimismo exposto no indianismo tem um fundo lógico, para Coutinho ${ }^{306}$. Muitas das lágrimas do poeta encontram explicação nos poemas indianistas, "pelo que o poeta tem de fundo índio; muita pelo seu mal de origem, que tanto acabrunha; muita pela vocaçáo brasileira para a tristeza sem motivo (o prazer secreto da tristeza)."

\footnotetext{
302 V. Pereira 199296.

${ }^{303}$ V. Pereira 1992123.

${ }^{304}$ Williams 198320.

${ }^{305}$ Williams 198321.

${ }^{306}$ Coutinho 198683.
} 
De facto, poema Deprecação não é semelhante ao raro documento de Bernardino de Sahagún Historia general de las cosas de Nueva España. Embora o poema Deprecação pareça ser a destruição das tribos indígenas narrada por um índio centenário, enquanto o seu deus está com um denso véu de penas que o impede de ver o sofrimento do seu povo, o poema gonçalvino ainda não é um retrato análogo a Sahagún, porque este tem uma perspectiva dos astecas, da destruiçáo cometida por Cortés e os seus soldados. Para Kothe ${ }^{307}$, esta é a lacuna na literatura brasileira: não ter uma perspectiva indígena.

Conforme vimos, a tentativa gonçalvina não é ainda o olhar do indígena, mas o olhar que o europeu deu ao indígena. Gonçalves estudou na Universidade de Coimbra, que, conforme Souza Pinto $^{308}$ afirma, é a "madrinha espiritual" da literatura brasileira. Mas Deprecação surge com o esforço de desmitificar o que se havia instaurado desde a carta de Caminha - o mito de que a colonização portuguesa teria sido mais branda e mais humana do que a espanhola, como se os portugueses tivessem sido melhores cristãos que os espanhóis ${ }^{309}$. 


\title{
7. A estilizaçáo nostálgica daquilo que náo se deixa mais cantar
}

\author{
"É um poema americano, bem nosso, exclusivamente \\ nosso, é um episódio de raça indígena do Brasil idealizado pelo \\ poeta de suas desgraças, de suas guerras, de seu heroísmo. Está \\ cantado em magníficos versos, que só podiam inspirar a nossa \\ natureza e esse sol fecundo que nos alumia."
}

Francisco Otaviano

"Imaginei um poema... como nunca ouviste falar de outro: magotes de tigres, coatis, de cascavéis; imaginei mangueiras e jabuticabeiras, jequitibás e ipês arrogantes, sapucaieiras e jambeiros, de palmeiras nem falemos; guerreiros diabólicos, mulheres feiticeiras, sapos e jacarés sem conta; enfim, um gênesis americano, uma Ilíada brasileira, uma criação recriada.

Passa-se a ação no Maranhão e vai terminar no Amazonas com a dispersão dos Timbiras, guerras entre êles e depois com os portuguêses.

O primeiro canto já está pronto, o segundo começado ${ }^{310 . "}$

Com estas palavras, Gonçalves Dias anunciava ao seu amigo Henriques Leal o nascimento da epopeia Os Timbiras ${ }^{311}$.

De acordo com Adorno e Horkheimer ${ }^{312}$, cantar a ira de Aquiles e as aventuras de Odisseu já é uma estilização nostálgica daquilo que não se deixa mais cantar, porque o herói das aventuras revelase precisamente como o protótipo de um indivíduo burguês, cujo conceito tem origem naquela auto-afirmaçáo unitária que encontra o seu modelo mais antigo no herói errante.

Cantar as aventuras dos Timbiras, também se torna uma estilização nostálgica daquilo que não se deixa mais cantar, em primeiro lugar, porque a epopeia de Gonçalves remonta a uma era em que os poemas longos estavam já praticamente extintos, e talvez seja por este motivo que o poeta não terá concluído a sua obra, ou, pelo menos, terminou e não tivemos acesso, como alegam alguns teóricos, com base nas palavras de Henriques

310 Moisés 198936.

311 Ricardo 196456.

312 Adorno e Horkheimer 198553. 
Leal $^{313}$. Em segundo lugar, devemos considerar que a nostalgia do índio puro, anterior à chegada do europeu, náo pode prefigurar um sentimento patriótico; porque, de facto, o índio precedente nunca terá sido brasileiro, e o contíguo à existência do Brasil, incorporado pela força colonial, também não se justifica. A nostalgia da liberdade, que o índio anterior possuía e perdeu, não equivale à liberdade que o Brasil conseguiu com a conquista da independência política. Ambas as coisas estáo num patamar totalmente divergente. Portanto, cantar a primeira como símbolo da reconquista não é plausível.

Sabe-se que Gonçalves era a favor do Império do Brasil. Embora fosse favorável às eleiçóes para legislaturas, reconhecia a necessidade de um governo político dominante. No curso da sua obra, o poeta colocaria dois chefes à prova: Itajuba como governante dominante, que não aceita desobediência de nenhum membro, nem a interferência dos guerreiros. Além disso, diante da negação do Piaga em implorar pelo povo diante de Tupá, é o cacique Timbira que toma partido em favor de todos. Do outro lado, está Gurupema, cacique democrático, que coloca a sua chefia à disposição da bem querença dos seus camaradas e que, em lugar de tomar partido por todos, prefere reunir um concílio para tomar decisóes importantes. O sistema político que Gonçalves exalta é justamente aquele que estava fadado ao desaparecimento. Em meio século, o Brasil deixaria de ser um Império.

Para Martindale ${ }^{314}$, "The American Indian could indeed be idealized as an image of pristine and uncorrupted primitivism, but this did not save her from annihilation or confinement to reservations." Com isto, toda esta estilização nostálgica fica comprometida. O próprio acto de cantar um povo extinto equivale a extinguir as convençóes épicas a favor das antiépicas. De acordo com Kothe ${ }^{315}$, a partir do instante em que o herói épico decai na sua "epicidade", tende a crescer em humanidade. Naturalmente que um canto de um povo extinto não o deixaria de ser sem dores, melancolias e consternaçóes profundas.

A obra Os Timbiras, no seu conteúdo, acabou por se resumir à exposição das lutas que se desenrolaram entre duas tribos indígenas, a dos Timbiras e a dos Gamelas, pelo predomínio da

313 Moisés 1989 36; Coutinho 1986 86; Ricardo 1964 66; Cândido 1993 85; Ackermann 1964134.

${ }^{314}$ Martindale 199342.

${ }^{315}$ Kothe 198714. 
primeira pela segunda. A obra enquadra grande parte das cenas particulares da vida dos indígenas, nas descriçóes da natureza e dos pensamentos relacionados com a exploração do índio pelo europeu.

Para além das paisagens nativas e da forma pitoresca que descreve o elemento indígena, o poeta, às vezes, na forma rude do falar indígena, narra os costumes, a vida no seio da tribo, as lutas e as festas, trabalhos e divertimentos, crenças e ritos. De certa maneira, esta epopeia pode ser interpretada como um protesto da natureza e dos seus íncolas contra o colonizador que, depois de roubar a terra ao vencido, escravizou o primitivo habitante.

A estilização nostálgica é o carácter central de toda esta narrativa épica. Os versos do poeta de per si contêm suspiros de saudades de tempos passados, de lugares queridos que nunca se hão-de rever, de flo estas devastadas e de uma civilização que se extinguiu. Segundo Ackermann ${ }^{316}$, o pessimismo cultural é talvez o sentimento que terá inspirado ao poeta este protesto. $\mathrm{Na}$ introduçáo da obra, Gonçalves esboça numa amplitude o objectivo da epopeia:

Os ritos semibárbaros dos Piagas,

Cultores de Tupã, a terra virgem

Donde como dum trono, enfim se abrira

Da cruz de Cristo os piedosos braços;

As festas, e batalhas mal sangradas

Do povo Americano, agora extinto,

Hei de cantar na lira. (OT i.1-7)

Gonçalves propóe-se cantar as festas, as lutas ferozes e os ritos "do povo extinto e a terra virgem", de onde teve início, outrora, a difusão do Cristianismo. Evoca, como representante deste povo, a "sombra do selvagem guerreiro" que, a passos incertos, o arco partido e a aljava rota, caminha triste e avesso ao trato humano, pela terra dos seus antepassados, em vão procurando asilo (OT i.7-16). O poeta lança, desta maneira, um olhar reflexi o sobre o remate da epopeia, formando, assim, o arcabouço que emoldura os seus cantos, para os quais desejaria ter a energia e a voz influente do pajé.

A invocação é uma característica própria das narrativas épicas: na Ilíada, Homero invoca a Musa para cantar a cólera de Aquiles Pelida, causa da guerra e de os Aqueus sofrerem

${ }^{316}$ Ackermann 1964114. 
trabalhos inúmeros e numerosas almas de heróis terem partido para o Hades. Na Odisseia, Homero evoca a musa para que cante o varáo astucioso que errou de clima em clima... que padeceu mil sofrimentos para se salvar a si e aos seus; esforço vão, visto que todos pereceram pois, insanos, devoraram os bois de Hipérion. Na Eneida, Virgílio também invoca a figura da musa para cantar os feitos do troiano Eneias que, fugindo das muralhas derribadas de Tróia, na procura da terra prometida, padeceu pelos mares, vítima de sofrimentos mil, até encontrar o destino final

Gonçalves copiou o modelo épico dos gregos e romanos, embora, durante o romantismo, muito se dedicassem os poetas a fugir dos modelos gregos, principalmente, no caso dos poetas brasileiros, do modelo camoniano ${ }^{317}$. Todavia, a epopeia gonçalvina estrutura-se à semelhança de tais obras, conforme percebemos. O pessimismo cultural de que fala Ackermann pode ser observado desde o início do poema; para cantar a cultura semi-bárbara, o poeta evoca a sombra de um selvagem guerreiro. A sombra, claridade atenuada pela interposição de um corpo entre ela e o objecto luminoso, ou a silhueta que um corpo desenha numa superfície quando ela se interpóe entre ela e uma luz, ou o fantasma, o espectro, seja o vislumbre daquilo que perdeu o seu antigo brilho, a sua antiga grandeza ou influência, são imagens que entristecem o espírito, e de certa forma a luz e a penumbra são a antítese temática recorrente da epopeia de Camóes. No fundo, o tema tem o seu início na obra de Virgílio, portanto os pessimismos do poeta romano e do lusitano reflecte -se claramente no carácter central da narrativa de Gonçalves Dias.

No final da introdução, o poeta abre uma esperança de quadros sorridentes e factos aprazíveis, intercalados entre as rudes descriçóes de lutas e de mortes:

Nem só me escutareis fereza e mortes:

As lágrimas do orvalho por ventura

Da minha lira distendendo as cordas,

Hão de em parte ameigar e embrandece-las.

Talvez o lenhador quando acomete

O tranco d'alto cedro corpulento,

Vem-lhe tingido o fio da segu e

De puto mel, que abelhas fabricaram;

317 Ricardo 196465. 
Talvez tão bem nas folhas qu'engrinaldo,

A acácia branca o seu candor derrame

E a flor do sassafraz se est ele amiga. (OT i.50-60)

Mas os trechos plenos da escuridáo nocturna seriam bastante marcantes na epopeia ${ }^{318}$. O poeta reage, desta forma, ao modelo camoniano, alcançando uma atitude épica distinta. Não usa uma tuba belicosa, náo diz que outra voz muito superior se levanta. Antes, cantor humilde, engrinalda a lira com ramo verde e escolhe um tronco de palmeira junto ao qual desferirá o seu canto $^{319}$; porém, o pessimismo é o instrumento que Gonçalves não conseguiu excluir da influência de Virgílio e Camóes.

$\mathrm{O}$ primeiro canto da epopeia inicia-se com a apresentação de Itajuba, cacique dos Timbiras:

Itajuba, o valente, o destemido

Acoçador das feras, o guerreiro

Fabricador das incansáveis lutas. (OT 1.3-5)

É semelhante ao pai Jaguar, célebre por todo canto, tido como invulnerável. Milagrosamente, o Piaga transmitiu essa faculdade do cadáver inútil do pai ao filh . Com a supressão deste encanto, dissipou-se também a sua glória, tanto entre os homens de sua tribo quanto nas naçóes vizinhas - o que culmina na origem das batalhas com os Gamelas. No diálogo que se segue, o chefe dos Gamelas, jactancioso e sedento de glórias, desafia o cacique Timbira, apresentando-se seguro de sua força e superior ao adversário. Convida-o para decidirem, através de um duelo, a questão do esforço e brios (OT 1.56). O quadro que se pinta a seguir, o duelo dos caciques Timbira e Gamela, é uma imitação do combate entre os heróis homéricos.

Os espíritos protectores das duas tribos intervêm activamente; fazem as flechas errarem o alvo (OT 1.81). A do Gamela entra num tronco e só pára ao atingir o cerne; a do Timbira fugiu mais longe, roçando os frondosos cimos. Partem-se as armas (OT 1.86); os adversários combatem corpo-a-corpo revolvendo a terra aos pés; e ao longe é possível ouvir rouquejar o peito arfado e um som confuso (OT 1.89-92). O duelo é igualitário: um gigante robusto pugna contra um adversário extraordinariamente ágil e não menos forte (OT 1.101). A igualdade é notória, ambos se

318 Ricardo 196464.

319 Ricardo 196465. 
separam e a acção é de ambos; ambos arquejam; ambos o ar em ondas sôfregas respiram; cada um mais pasmado com a força do outro do que medroso. E a resistência é o que mais os irrita (OT 1.111-118).

Raiva de tigre anuviou-lhe o rosto

$\mathrm{E}$ os olhos cor de sangue irados pulam

A tua vida a minha glória insulta!

Grita ao rival, e já demais viveste. (OT 1.124-127)

O quadro épico do herói e chefe Timbira, cujos olhos vermelhos irados pulam, expressa na sua forma mais sublime a destreza guerreira que o assalta. A batalha dos caciques é um quadro horrivelmente belo (OT 1.147). O vermelho tem duplo significad. Ao mesmo instante que significa a vida, também pod significar a morte. No quadro representado, os olhos cor de sangue representam o desejo de morte imanente em Itajuba. De acordo com Putnam ${ }^{320}$, o vermelho e o branco são duas cores sugestivas, um contraste muito grande no último momento da Eneida. Para Bodkin $^{321}$, o vermelho tanto se associa à morte como à vida. "On purpureus as a color associated with death as well as life."

Os olhos carmesim de Itajuba, a expressão de descontentamento diante da resistência do inimigo contrastam em muito com a comparação que se segue. $\mathrm{O}$ poeta compara a investida de Itajuba sobre o cacique dos Gamelas com o voo do condor que, descendo a prumo dos astros sobre o lama descuidoso, prende-o nas garras potentes e sobe, audaz, onde não chega o raio, isto é, acima das nuvens. Eis uma imitação de Gonçalves em relação a Virgílio e Homero. Turno inofensivo, derrotado pelas mãos de Eneias, implora pela vida ${ }^{322}$. Príamo é uma figura patética e símbolo da desonra que é matar um homem idoso em batalha ${ }^{323}$. O cacique dos Gamelas, que luta bravamente, tal como teria feito Príamo durante a juventude e Turno nos momentos que antecedem a sua derrota, é no último golpe semelhante a Príamo vencido pela idade e Turno vencido pelo desejo de vida.

O cacique é comparado ao lama, um animal vegetariano que em nada se compara com os índios antropófagos, animal calmo

${ }^{320}$ Putnam 1988158.

${ }^{321}$ Bodkin 1965 44-55.

${ }^{322}$ Clausen 198789.

${ }^{323}$ Quinn 19688. 
semelhante à ovelha. Quando é atacado pelos predadores, ainda que esteja prevenido não tem força. Dessa maneira, a força igualitária de ambos esvai-se, dissipando-se o poder do chefe dos Gamelas, assim como a força de Turno abandonado pelos deuses ou como a força de Príamo, decaída pela idade.

Itajuba voa sobre o rei das selvas. Cinge-o nos braços e aperta-o com força incrível contra si. O gigante verga, inclina-se, desaba e cai num choque repentino (OT 1.132-135). A batalha triunfal da epopeia de Gonçalves ganha carácter antiépico. A vitória gloriosa de Itajuba mancha-se, porque não vencera o Gamela de maneira justa. A destreza idêntica, a separação repentina, decisão de ambos, contrasta com o ataque traiçoeiro de Itajuba: este não dera ao Gamela a opção de lutar, simplesmente agarrara-o como o Condor que agarra o Lama desprevenido. Comprime-o tirandolhe os movimentos dos braços e das pernas, como o Condor que carrega o Lama para as alturas, onde não poderá defender-se. Itajuba pensa apenas na vitória, como Eneias também pensara, mas a morte aplicada ao inimigo é impiedosa e traiçoeira.

O poeta tenta embelezar a cena abominável: compara o tombo do Gamela com a queda de um tronco anoso que levanta o pó da terra e propaga ao longe o barulho da sua queda (OT 1.136-138). Itajuba, porém, ainda bate o pé na arca do peito do desfalecido guerreiro desferindo palavras de morte. O Gamela sem alento, com os olhos turvos observa pela última vez o céu azul, as matas doces cobertas de verdura e flo es.

\author{
Depois, erguendo o esquálido cadáver \\ Sobre a cabeça, horrivelmente belo, \\ Aos seus o mostra ensangüentado e torpe; \\ Então por vezes três o horrendo grito \\ Do triunfo soltou; e os seus três vezes \\ $\mathrm{O}$ mesmo grito em coro repetiram \\ Aquela massa enfim côa nos a es; \\ Porém na destra do feliz guerreiro \\ Dividem-se entre os dedos as melenas, \\ De cujo crânio marejava o sangue! (OT 1.146-155)
}

Eis a face do triunfo, o cadáver pálido, ensanguentado e imundo; o grito triplo de Itajuba repetido pelos seus homens; a imagem repugnante dos dedos entre os cabelos marejados de sangue, contrastando com a felicidade de Itajuba, esconde o lado traiçoeiro e macabro do duelo. $\mathrm{O}$ orgulho do guerreiro, a ufania 
do sucesso, esconde o lado sombrio que mancha a reputação do duelo.

Como se o duelo precisasse de um eco, o poeta faz o vencedor recordar mais uma vez as várias partes ${ }^{324}$. O poeta dá-nos a conhecer que os Gamelas, tendo fugido de noite, se subtraíram $\mathrm{da}$ vassalagem, fuga de que o chefe Timbira jura vingar-se. $\mathrm{Na}$ realidade, o que o poeta tenta nesta recordação, neste eco, na fuga dos Gamelas, é corrigir a aversão do combate, dando um carácter de sucesso à vitória manchada pela reputação de um duelo vencido falaciosamente. $O$ poeta quer redimir Itajuba, afirmando que o herói Timbira é injustiçado pela fuga dos seus vassalos conquistados honrosamente.

Segue-se o diálogo entre Itajuba e Jurucei, o qual, tomado de sobressalto, vem correndo para junto do chefe, a fim de o informar acerca do avanço dos incontestáveis igaras ${ }^{325}$ repletos de Gamelas. Encerra-se o diálogo com as palavras de Itajuba que, aparentemente calmo, mas com o coração ardendo de ódio e desejo de vingança, envia Jurucei como mensageiro, a levar aos Gamelas uma mensagem claramente formulada.

No encerramento do primeiro canto, Itajuba passa em revista os seus guerreiros. Do alto de uma montanha, ele observa, com altivo sorriso e consciente de desfrutar da protecção de Tupá e dos heróis mortos, como aos sons do búzio acodem azafamados os seus homens de armas. Nomeia-os em parte com os seus nomes sonoros: Jucá, Jacaré, Catucaba, Juçurana, Japeguá, Mojacá, Mopereba, Itaroca, Japi, Camotim, Pirajá, Jatir e muitos outros. Gonçalves, às vezes, inserindo algum episódio com todas as minudências, ora enfatiza as características mais salientes e os feitos heróicos de cada um, ora a sua obediência e fidelidade. A propósito do nome de Jatir, que está ausente, o poeta descreve um episódio, no qual Itajuba defende a sua dignidade de chefe em face dos louvores excessivos que Ogib, o pai de Jatir, tributa ao filho, chegando mesmo a ap egoá-lo o melhor de todos.

Jatir é comparado pelo pai ao sabiá que geme sozinho no campo, e ao Condor que aos céus remonta; não é como os anuns que folgam em bando, ou como os catetes que em vara pascem (OT 1.347-350). O pai de Jatir eleva o filho como o melhor entre os Timbiras e Itajuba reivindica o seu reconhecimento:

${ }^{324}$ Ackermann 1964116.

325 Pequena canoa construída normalmente a partir de um tronco de árvore escavada. 
bem maneja o arco,

Vibra certeira a flecha; mas...(sorrind

Prossegue) afora dele inda há quem saiba

Mover tão bem as armas, e nos braços

Robustos, afogar fortes guerreiros. (OT 1.366-373)

O canto termina com esta discórdia entre Ogib e Itajuba. Mas se a imagem de Jatir é semelhante ao sabiá que solitário geme ao invés de cantar, se a figura de Condor, já atribuída a Itajuba e agora a Jatir por este se aventurar sozinho, é uma explicação melancólica para o desaparecimento do herói, Gonçalves dirigenos da discórdia entre os heróis Timbiras para o ambiente em que caminha Jurucei, mensageiro de Itajuba, encerrando assim o primeiro canto com expressóes melancólicas da natureza:

As aves docemente atitam,

De ramo em ramo - docemente o bosque

A medo rumoreja, - a medo o rio

Escoa-se e murmura: um borborinho,

Confuso se propaga, - um raio incerto

Dilata-se do sol doirando o ocaso.

Último som que morre, último raio

De luz, que treme incerta, quantos entes

Oh! hão de ver a luz de novo

E o romper d'alva, e os céus, e a natureza

Risonha e fresca, - e os sons, e os ledos cantos

Ouvir das aves tímidas no bosque

Outra vez ao surgir da nova aurora?! (OT 1.379-391)

Eis um misto de optimismo e pessimismo; no meio do caminho de Jurucei, Gonçalves descreve os fenómenos da natureza com palavras tanto optimistas como pessimistas: o canto doce das aves é o único fio de esperança, num universo em que o bosque sussurra de medo, enquanto o rio corre murmurando, provocando uma expressão incerta e confusa. Logo acima, um raio incerto do sol se dilatava dourando o ocaso, e o dia find -se com a expressão de que morre o último som, e treme o último raio de luz. $\mathrm{O}$ barulho natural da flo esta torna-se para o poeta um som de desespero. $\mathrm{O}$ burburinho das águas torna-se um som de angústia intraduzível, como o prenúncio de novos acontecimentos.

Quando, enfim, o último raio se dilatou e morreu (uma expressão descomunal, porque na verdade os raios solares não 
morrem), o poeta, enfim, dirige uma pergunta que acompanha o desespero expressado pela natureza: a luz vai-se, desaparece mais um dia, e o poeta angustiado pergunta quantos entes, depois de uma nova aurora, veriam outro romper da alva, e os céus, e a natureza risonha e fresca, os sons e os cantos alegres das aves da flo esta. Eis a esperança de dias felizes, de uma natureza hilariante, de uma flo esta encantadora. Eis o desespero por aqueles que não hão-de contemplar os dias esperançosos, uma esperança ameaçada pela ruína, pela destruição. Mas o poeta não nos conta o que havia de subtrair esta esperança.

O primeiro canto narra a morte impiedosa do cacique Gamela, numa expressão de crueldade indígena que certamente Gonçalves não queria expressar, mas que escapa. Porque o duelo não é justo. $\mathrm{O}$ Gamela é subtraído pela traição. $\mathrm{O}$ seu adversário tirou-lhe o poder de reacção ao tomá-lo de surpresa. Há uma grande disparidade entre a reacçáo que a morte de Tabira pode provocar, em comparação com a morte do Gamela. A morte à traição desperta no outro o sentimento de comiseraçáo pelo que morre e de maldição pelo assassino, ao contrário da morte em duelo justificado, que desperta no outro um sentimento de heroísmo por ambas as partes do duelo. Enfim, o primeiro canto está cheio de agonia, de ânsia, aflição, desespero e angústia. Expresso tanto no duelo central, quanto nos diálogos de Jurucei e Itajuba, ou na discórdia de Itajuba e Ogib, que não poderiam terminar com o mesmo desespero. Porque o canto encerra-se com a noite, e é nesta penumbra que avançamos para o segundo.

As primeiras palavras do segundo canto de Os Timbiras denunciam a imagem taciturna expressa no término do canto anterior. $\mathrm{O}$ manto escuro da noite enreda-se na flo esta e murmura e o poeta, enfim, manifesta, nas suas palavras de desesperança, a imagem da morte.

Desdobra-se da noite o manto escuro:

Leve brisa subtil pela flo esta

Enreda-se e murmura, - amplo silêncio

Reina por fim. em saberás tu como

Essa imagem da morte é triste e torva.

Se nunca, a sós contigo, a pressentisse

Longe deste zunir da turba inquieta.

No ermo, sim; procura o ermo e as selvas...

Escuta o som final, o ext emo alento,

Que exala em fins do dia a natu eza! 
O pensamento, que incessante voa,

Vai do som à mudez, da luz às sombras

E da terra sem flo, ao céu sem astro.

Simelha a graça luz, qu'inda vacila

Quando, em ledo sarau, o extremo acorde

No deserto saláo geme, e se apaga! (OT 2.1-16)

A morte que espreita na inquietude da natureza é a causa de angústia do poeta. Na estrofe posterior, o termo "era" é a expressão mais pura da nostalgia dos dias de glória da tribo Timbira. O poeta entáo escapa das dores da morte ressentida no início do canto para a felicidade de um passado glorioso, de uma tribo pujante, das três tabas Timbiras, habilmente construídas entre duas colinas e cercadas da natureza tropical de viçosa flo escência que, para Ackermann ${ }^{326}$, parecem elevar-se diante do leitor, como garbosos seres da natureza.

Eram três flo es em três hastes diferentes, provenientes de um mesmo tronco, como se fossem três irmãs formosas (OT 2.22-23). Perfumadas pelo cajazeiro, era a imagem viva que provinha do cajueiro. As mangas curvadas como o arco beijavam os tectos das tabas, e a sapucaia lambia a terra, enquanto doces maracujás sorriam entre as flo es do pau-d'arco e a úsnea das palmeiras (OT 2.28-38). São expressóes de nostalgia de uma época em que as tribos indígenas viviam felizes. Mas, na estrofe seguinte, o poeta corrobora com o pessimismo impregnado na obra:

Quadro risonho e grande, em que não fosse

Em granito ou em mármore talhado! (OT 2.39-40)

O poeta testemunha que aquelas paisagens não viram palácios, nem torres, nem castelos, nem grimpas, nem zimbórios, nem construçóes de pedra; viram apenas rudes palhoças. Mas por que haveria de ver mais quem há de ter apenas um sol na vida? Porque a dor sentar-se-ia e a morte revoar-se-ia tão solta em gritos; semelhante ao que havia acontecido nos átrios, a compaixáo cobriria o ambiente de dó, limpando as lágrimas do aflit . Numa analogia em que as dores que sobressaltaram os castelos também assaltaram as palhoças rudes dos primitivos habitantes americanos, o poeta então pergunta "Que sobra pois em nós, que falta neles?" (OT 2.55).

${ }^{326}$ Ackermann 1964117. 
E, no verso seguinte, o poeta remete-nos para a tribo dos Timbiras, confrontando-nos com a atitude mental e física dos guerreiros quando voltam da revista, reflectindo a confiança readquirida em Itajuba e a falta de medo de todos, diante das coisas vindouras, porque estão convencidos de que o chefe tem auxílio e protecçáo de Tupã e dos Manitôs (OT 2.56-68). Gonçalves dirige-nos novamente para Itajuba e o Piaga, duas personagens principais numa tribo. O Piaga, ornamentado para o acto sagrado, caminha com passos majestosos, saindo da caverna nunca palmilhada por outro indivíduo, e vai dançando sob o ritmo do maracá, revolvendo os Timbiras carregados de sono. O Piaga dirige então um canto melancólico (OT 2.83-132), solicitando Tupã para que proteja os seus guerreiros contra os maus espíritos e faça descer sobre eles sonhos de triunfos e de glórias.

De acordo com Coutinho ${ }^{327}$, o papel do sonho, do mito, do maravilhoso na epopeia é considerado pelos exegetas de Homero e Virgílio como tipicamente épico. A clara referência aos sonhos, cujos significados eram primordiais no seio das tribos indígenas, deixa viva a intenção poética de Gonçalves em construir uma epopeia.

O canto do Piaga traz as expressóes de tristeza com o crescimento do poder de Anhangá durante a noite; a interferência traiçoeira dos Caraibebes nos sonhos; o canto triste que a acauã desata a entoar, prognosticando males aos guerreiros; o bando tristonho de urubus vorazes; o abandono das tabas pelos Manitôs; expressóes de melancolias, quando enfim o poeta deveria celebrar a alegria, a glória daqueles que partiam para a batalha. Porém, Gonçalves não canta uma tribo de vencedores semelhante à glosa homérica sobre a guerra que os Aqueus promoveram a Tróia; não canta uma nação derrotada, cujos remanescentes partem para recomeçar a civilização, conforme fi era Virgílio. Gonçalves é o cantor de um povo extinto, de uma naçáo que não terá um recomeço, e o seu cântico centra-se num passado pujante. $\mathrm{O}$ grande pessimismo surge em face de um tempo que náo pode ser resgatado porque, entregues à invasão do colonizador, os primitivos habitantes chegaram a um ponto de onde náo puderam retornar.

Enquanto o Piaga dirige o seu canto em torno dos Timbiras, todos adormecem, menos o chefe que vela ainda, entregue a ocultos pensamentos. Primeiro, o poeta abre um leque de

${ }^{327}$ Coutinho 198689. 
possibilidades: estaria o chefe Timbira fabricando ásperas ciladas de guerra e enxergando, desfeita em sangue, a revolver-se em gritos, a morte pávida? Ou sentia e avistava a mente do Deus da guerra, impávido Aresqui, a calcar aos pés cadáveres sem conto (OT 2.134-141). Mas o poeta desfaz a imagem "nem combates, nem lágrimas medita" (OT 2.148). Sentia na alma um sentimento gelado e mudo como o véu da noite, e o seu pensamento estava tomado pelo paradeiro de Jatir: onde e como estaria o guerreiro Timbira? E formula o desejo de que Tupã dê mais fama e glória ao amigo ausente (OT 2.149-161).

A descrição e o monólogo que se seguem referem-se ainda à melancólica disposição de espírito de Itajuba, que se eleva a um presságio fúnebre e a uma imensa tristeza ${ }^{328}$ (OT 2.170-184). Conjectura-se nestes versos que Itajuba foi atingido por uma desventura pessoal. Esta desgraça é, de facto, comunicada no canto melancólico de Croá, o "sabiá das matas", que canta a pedido do chefe indígena, para lhe abrandar a tristeza. A cena seguinte, Ackermann ${ }^{329}$ compara-a com diamantes num colar de pérolas. Desenvolve-se numa noite silenciosa entre dois índios, na taba mal iluminada por tochas resinosas; o cantor, dançando ao som do maracá, entoa um comovente e triste canto pela morte de Coema, mulher amada de Itajuba, que fora raptada e perdera a vida (OT 2.196-342).

Gonçalves aumenta o efeito do canto, alternando entre a exaltação lírica da formosura e a lamentação fúnebre, que se fundem com a exposição épico-dramática do acontecimento, e, no ápice trágico, o cantor interrompe a instâncias do chefe dominado pela dor (OT 2.294-299 e 306-318); então Itajuba continua o canto, que se prolonga pelo sonho do chefe indígena, que afinal também adormecera sob o canto do Piaga.

A cena que se segue fecha o segundo canto da epopeia: Ogib apreensivo pela sorte do filho, e Itajubá, do mesmo modo, pelo amigo, não podem conciliar o sono. $\mathrm{O}$ pai de Jatir vela cansado e triste com saudades do filh. Meditando na taba escura, o velho treme e a voz falta-lhe, ao tocar num corpo molhado e tiritante. É Piaíba que, vagueando de noite nas matas, tem um encontro com a morte, junto ao sepulcro de Coema. Piaíba tem uma mensagem de morte para Ogib, desenvolvendo-se aqui um

${ }^{328}$ Ackermann 1964 117-118.

${ }^{329}$ Ackermann 1964118. 
monólogo de fundo lírico, que posteriormente se converte num diálogo desesperado ${ }^{330}$ entre Ogib e Piaíba.

Dou-lhe a mensagem, que me deu a morte,

Quando acordar!

Eu via a morte: vi-a bem de perto

Em hora má!

Vi-a de perto, não me quis consigo,

Por ser tão má.

Só não tem coração, dizem os velhos,

E é bem de ver;

Que, se o tivera, me daria a morte,

Que é meu querer.

Não quis matar-me; mas é bem formosa;

Eu vi-a bem:

É como a virgem, que não tem amores,

Nem ódios tem. (OT 2.370-383)

Raríssimas vezes a morte teria um aspecto agradável, mas para quem quer entregar-se às garras da morte, ela ganha beleza. A morte que surge dos monólogos de Piaíba mostra-se perfeita e claramente porque ela é semelhante à virgem que não tem amores nem ódios, nem ao menos tem coração; porque, para Piaíba, se a morte tivesse coração, levá-lo-ia, subtrair-lhe-ia a vida, e a maldade que vê na morte é pelo facto de por ela não conseguir deixar-se conduzir, mas considera-a no entanto bela, formosa. Piaíba, o louco, anuncia a morte a Ogib. O pai de Jatir ouve a canção e sente frio; um frio que não é apenas sentido fisicamente - é o frio da morte, senáo o frio do calafrio ${ }^{331}$. E o segundo canto encerra-se com as súplicas de Ogib:

- "Tupã, que tudo podes,

Orava Ogib em lágrimas desfeito,

A vida inútil do cansado velho

Toma, se a queres; mas que eu veja em vida

Meu filho, só depois me colha a mo te! (OT 2.447-451)

Eis um fio de esperança. Se Ogib visse o filho apenas uma vez já morreria feliz. A proposta gonçalvina consiste numa alternância em que, por vezes, o herói se encontra com uma determinaçáo robusta e logo desaba num conflito interior, como

${ }^{330}$ Ricardo 196458.

${ }^{331}$ Ricardo 196465. 
se vencesse as batalhas, mas não esquecesse o trauma que delas trouxe consigo. Assim, o poeta ora canta os feitos indígenas, ora canta o aniquilamento a que são submetidos.

O segundo canto compóe-se de uma série de cenas particulares que, simplesmente justapostas e sem vinculação estreita entre si, náo adiantam directamente ao desenvolvimento da acção. Todavia, preparam o terreno para os acontecimentos posteriores, como por exemplo, o quadro dos guerreiros que recobram a sua confiança em Itajuba, com referência à significaçáo dos sonhos. Enfim, o canto termina com a oração de clemência, a oração mais significati a, o apego a um deus, mais em busca de soluçóes do que de agradecimento pelas bênçãos provenientes. A oração melancólica de Ogib, apesar de merencória, não pode ser considerada pessimista; o canto encerra-se com uma esperança comprometida.

O terceiro capítulo inicia-se com um quadro multicolor e caprichosamente pormenorizado do romper da alva na natureza ${ }^{332}$ (OT 3.1-39). Pela primeira vez, Gonçalves iniciou uma parte da sua epopeia com algumas expressóes de felicidade. Mas cedo o poeta, nestas figuras nostálgicas de uma felicidade passageira, se lembraria das três tabas dos Timbiras que estavam entre os montes. Eis uma imagem do vigor que possuíam:

As três formosas tabas de Itajuba

Já foram como os cedros gigantescos

Da corrente impedrada: hoje acamados

Fósseis que dormem sob a térrea crusta,

Que os homens e as naçóes por fim sepultam

No bojo imenso! - Chame-lhe progresso

Quem do extermínio secular se ufana:

Eu modesto cantor do povo extinto

Chorarei nos vastíssimos sepulcros,

Que vão do mar ao Andes, e do Prata

Ao largo e doce mar das Amazonas. (OT 3.40-50)

$\mathrm{O}$ poeta promete sentar-se junto às margens doces do rio Amazonas e de lá, meditabundo, longe do barulho dos machados europeus manejados pelas mãos de escravos africanos, sem ver as matas arrasadas nem os troncos chorando a preciosa goma, chorar os vastíssimos sepulcros, que iam desde o mar aos Andes e do Prata ao Amazonas, e cantar as três modestas tabas agora

${ }^{332}$ Ackermann 1964119. 
destruídas, que já foram semelhantes aos cedros gigantescos da corrente empedrada. Nelas personificaria a triste destruição do primitivo habitante americano.

Gonçalves Dias, em negação ao modelo camoniano, denomina-se modesto cantor do povo extinto, ao contrário de Camóes, que manifesta uma voz muito superior, capaz de calar os conquistadores troianos e gregos, como referência a Homero e Virgílio ${ }^{333}$. Gonçalves, durante todo o tempo da sua vida, sofreu com o complexo de inferioridade que possuía o poeta que reconhece a falta de sangue azul, e faz questáo de referir a sua condiçáo inferior ${ }^{334}$, como se buscasse graça ou algum tipo de benevolência pelo seu reconhecimento. Procura não sofrer, mas sofre; diz que não deplora, mas chora; procura manter-se forte, mas reconhece a fraqueza que o acomete; em suma, na sua poética, Gonçalves tem apenas uma ambição: a glória de ser o maior do seu tempo, construindo um conjunto de poemas épicos e uma epopeia para cantar a raça genuinamente brasileira. Mas ao tentar diminuir os seus complexos, o poeta falha, e deixa manifestar na poesia os seus fracassos. Daí o carácter antiépico, o da antiepopeia. O próprio objecto poético - refi o-me aos índios - é um elemento que à sua semelhança foi inferiorizado, e mais ainda, sucumbido ao preço da inferioridade que adquiriu, porque Gonçalves, embora falhe no seu objectivo poético, triunfa entre os primeiros poetas, acabando por ser o mais notável e respeitável de seu tempo.

Nos trechos seguintes, o poeta continua a lamentar as desgraças que acometeram as tribos Timbiras, e então surge um dos cantos mais belos da epopeia, sem dúvida o mais famoso, o mais divulgado, a imagem da "América infeliz":

América infeliz! - que bem sabia,

Quem te criou táo bela e tâo sozinha,

Dos teus destinos maus! Grande e sublime

Corres de pólo a pólo entre os dois mares

Máximos de globo: anos da infância

Contavas tu por séculos! que vida

Não fora a tua na sazão das flo es!

Que majestosos frutos, na velhice,

Não deras tu, filha melhor do terno?!

Velho tutor e avaro cobiçou-te,

${ }^{333}$ Ricardo 196465.

334 Veríssimo 1997 249; Bandeira 199824 (a). 
Desvalida pupila, a herança pingue

Cedeste, fraca; e entrelaçaste os anos

Da mocidade em flor - às cãs e à vida

Do velho, que já pende e já declina

Do leito conjugal imerecido

À campa, onde talvez cuida encontrar-te! (OT 3.78-96)

A imagem da "América infeliz", onde o poeta derrama os seus lamentos, semelhante à imagem de uma criança inocente, cobiçada pelo velho tutor, a imagem da América que cede por ser fraca, por estar nos anos da infância, é um contraste grande com a imagem dos guerreiros indígenas, da bravura dos heróis.

A seguir, o poeta fala das naus de Holanda, dos galeóes de Espanha, das fragatas de França e das caravelas Portuguesas, que aportaram na América (OT 3.99-109). E o poeta denomina estes invasores de monstros marinhos que procuravam asilo numa terra estrangeira. E a tristeza do poeta recai sobre as tarefas dos nativos: enquanto estas embarcaçóes rumavam à América ao invés de fabricarem setas agudas e tacapes válidos, fabricavam-no capelas.

Enfim, a noite que se iniciou no término do primeiro canto, encerrou no início do terceiro, logo após o modesto cantor da tribo extinta derramar os seus lamentos em torno da "América infeliz". A alvorada trouxe um dia límpido e sereno (OT 3.126). Gonçalves prepara o ânimo prazenteiro dos guerreiros que se reúnem para o rito sacro, que consiste na explicação de seus sonhos pelo intérprete divino (OT 3.128-268).

$\mathrm{O}$ contentamento geral produzido pelos vaticínios do Piaga, pressagiando vitória e triunfo, dá origem a um novo incidente de graves consequências e sobre o qual o poeta se estende longamente. Entre Japegoá e Catucaba desenvolve-se uma briga. Japegoá sonhou com a morte, sangue coagulado e armas partidas e reprova, assim, o júbilo precoce pela vitória. A opinião contrária de Catucaba, a acusação de covardia, injúrias e insultos graves tornam inevitável o duelo (OT 3.358-405), cuja descrição é feita de forma concisa (OT 3.400-405), mas viva e impressionante.

Quanto à vertente da desunião, que se manifesta agora na divisão dos Timbiras em dois grupos, que se devia dar basicamente na sequência dos ultrajes dirigidos contra todos os amigos de Japegoá, o poeta contrapóe a pretensão de Itajuba que, interferindo com pujança ferina, restaura a concórdia. $\mathrm{O}$ cacique derruba um camarada cuja ousadia exprime 
insubordinação e amaldiçoa todos os que ousarem travar discórdias, "quando o inimigo boré tão perto soa!" (OT 3.432441). O quadro da discórdia entre Japegoá e Catucaba é uma imitação da obra homérica. $\mathrm{Na}$ segunda rapsódia da Ilíada, o soldado Térsites é surrado em público por Odisseu, pois, cansado de dez anos de guerra, o soldado apresenta uma reclamaçáo e uma reivindicação: para Térsites, os resgates originados de nobres troianos aprisionados pelos gregos revertiam apenas para os chefes, para os aristocratas gregos, tendo estes vantagens da guerra; propóe, além disso, que seria pertinente retornarem aos seus lares.

Para Kothe $e^{335}$, o discurso de Térsites é semelhante ao de um líder sindical dos soldados rasos; e o que diz tem fundamentos práticos, parecendo estar bastante de acordo com o que se poderia imaginar que fosse uma tendência entre a maioria dos soldados. Mas, para conter a audácia do camarada grego, Odisseu investe contra ele, e por isso é ridicularizado, é apresentado ainda como vesgo, corcunda e torto: uma figur inacreditável para um soldado. Para Kothe ${ }^{336}$, a figura ridícula e o papel desenvolvido por Térsites é sem dúvida digna de um quadro antiépico. Mas se, na epopeia homérica, Odisseu precisou de reparar a discórdia embalada por Térsites, antes que esta dividisse os guerreiros, na epopeia gonçalvina, Itajuba, o cacique dos Timbiras, também recorrerá ao mesmo estratagema. Ambas as personagens possuem personalidades diferentes, e por isso estavam sempre em combate:

Catucaba,

Fragueiro, inquieto, sempre aventuroso,

Em cata de mais glória e mais renome,

Sempre à mira de encontros arriscados,

Sempre o arco na mão, sempre embebida

$\mathrm{Na}$ corda tesa e frecha equilibrada.

Ninguém mais solto em vozes, mais galhardo

No guerreiro desplante, ou que mostrasse

Atrevido e soberbo e forte em campo

Quer pujança maior, quer mais orgulho.

Japeguá, corajoso, mas prudente,

Evitava o conflito, via o risco,

${ }^{335}$ Kothe 1987 15-16.

${ }^{336}$ Kothe 198714. 
Media o seu poder e as posses dele

E o azar da luta e descansava em ócio.

Sua própria indolência revelava

Ânimo grande e não vulgar coragem. (OT 3.318-333)

Catucaba interrompe a narração do sonhador de males. Japegoá tenta evitar o conflit . De acordo com o poeta, um era semelhante à luz fugaz presa às plumas de algodão, luz que descortina e logo amortece. Já o segundo era semelhante à faísca, que surda, pouco a pouco vai lavrando, não sendo vista nem sentida até que surge (OT 3.351-356). Um exército épico é unilateral, não apresenta rugas; mas a discórdia entre Catucaba e Japegoá é um episódio antiépico, porque é bilateral. A discórdia interna é a causa de ruína em um exército. Quando deveriam lutar por um interesse comum, os guerreiros dividem-se entre si, e trazem a morte para o seio do exército Timbira:

Já verga o arco, já se entesa a corda,

Já batem pés no solo pulvurento:

Correra o sangue de um, talvez o de ambos,

Que sobre os dois a morte, abrira as asas! (OT 3.401-404)

Mas o episódio de derramamento de sangue entre os guerreiros representa, afinal, um presságio que apenas se enquadra para a confirmação do sonho de Japegoá. O derramamento de sangue entre os guerreiros confirma como seriam os dias vindouros entre as tribos indígenas. Este acto é uma imitação comparável ao episódio em que, no Além, Eneias conhece alguns heróis nascituros, entre eles o jovem Marcelo. A sua referência, cuja morte virá prematuramente, traz a maior frustraçáo à comunidade que nele depositava as maiores esperanças. Para V. Pereira ${ }^{337}$, "Marcelo é o símbolo das dores que a pax Romana há-de custar." Catucaba e Japegoá, por sua vez, são o retrato das afliçóes que sobreviriam às tribos Timbiras.

Certamente para caracterizar quão grave é, na realidade, a situação da tribo Timbira, Gonçalves faz entrar a figura do Piaga; o líder religioso admoesta a Itajuba, advertindo com cautela, e prognosticando que, tendo-se derramado "propíguo sangue", o sonho narrado em último lugar preconiza o infortúnio dos Timbiras. Como contribuição da mesma ideia e para adiantar o enredo, intercala-se ainda a descrição de sonho, tido de particular

${ }^{337}$ V. Pereira 1992107. 
proeminência por ser de Mocajá, que é qualificado como circunspecto, prudente, optimista e objectivo (OT 3.452-468). Mocajá solicita que o Piaga considere o seu sonho nascido de uma fantasia perturbada pelo mau Anhangá.

Mocajá viu, num acampamento inimigo, um "guerreiro como vós”, preparado para o sacrifício. Com o fim de elevar a expectação dos ouvintes, o narrador silencia propositadamente em nome da vítima "Mas não direi, já, quem fosse o triste!" Entretanto a figura que traça do infeliz não deixa dúvida sobre quem possa ser (OT 3.477-482).

Sonho não foi, que o vi, como vos vejo;

Mas não vos direi já quem fosse o triste!

Se vísseis, como eu vi, a fronte altiva,

O olhar soberbo, - aquela força grande,

Aquele riso desdenhoso e fundo...

Talvez um só, nenhum talvez se encontre, eu seja para estar no passo horrendo

Tão seguro de si, tăo descansado!" (OT 3.474-481)

Ogib não tem a menor dúvida de que o personagem descrito não é outro senão o seu filho Jatir. Com voz chorosa e trémula clamava a Tupã, implorava por um esclarecimento, que mal teria feito ao deus para que fosse ferido com o furor e a seta envenenada. Ogib, à semelhança do velho Tupi em I-Juca Pirama, quer uma confissão, embora de todo já soubesse o mau agouro, mas quer ouvir do herói, como quem, duvidando, quer apenas confirmar o que já sabe.

Conheço o filho meu no que disseste,

Guerreiro, como a flor pelo pe fume,

Como o esposo conhece a grata esposa

Pelas usadas plumas da araçóia, (OT 3.496-499)

Mocajá, o prudente, o optimista, “já todo angústias” pela própria narração, evita uma confirmação directa, que Ogib desejaria ouvir; antes, procura consolá-lo recordando uma proeza, ainda viva na memória de todos os guerreiros, praticada por Jatir quando jovem guerreiro. Encerra então a narração do sonho e inicia a lembrança daquele feito destemido (OT 3.516-545).

Todavia, a recordação dos feitos de Jatir não foi capaz de dissipar a incerteza que, unida à admiração pelo herói ausente, 
novamente despertada, e à compaixão de todos por Ogib, constitui naturalmente a origem do conflito em que a cena agora degenera. Choros, lamentaçôes e gritos de mulheres e meninos em desordem e, no meio de tudo isto, a voz de Ogib, "que mal se percebe!"

Todo o campo se aflige, todos clamam:

"Jatir! Jatir! o forte entre os mais fortes."

Ordem não há; mulheres e meninos

Baralham-se em tropel: o pranto, os gritos

Confundem-se: do velho Ogib entanto

Mal se percebe a voz "Jatir" gritando. (OT 3.545-550)

Eis a imagem de melancolia superior às demais no terceiro canto. A ausência de Jatir acentua-se de forma a provocar tumulto entre os membros de sua tribo. Os choros, as lamentaçóes, os gritos são naturalmente elementos pertinentes de uma antiepopeia, porque eles manifestam o lado humano dos heróis. E quando sucumbem à perda inesperada, entram em profundo colapso sentimental. $\mathrm{O}$ próprio poeta, com o interesse de embelezar a cena confusa das lamúrias, faz questão de frisar que a voz de Ogib mal se apercebia, sendo que esta estava presente desde o momento em que se aperceberam da ausência do nobre guerreiro.

Itajuba interfere no rebuliço causado pelos lamentos dos membros da tribo, impóe o silêncio, aconselhando solicitarem ao Piaga que serene o irado Ibaque. Desta forma se transita para a cena extrema do terceiro canto.

O Piaga é a figura central deste episódio. O chefe religioso nega o seu auxílio sob o pretexto de se lembrarem dele somente nas maiores afliçóes, e deixarem sempre o maracá sem ofertas. Quando o líder religioso o finca no terreiro, faz questão de mostrar como o maracá está vazio, queixa-se dos Timbiras e lembra que não sentiu fome porque recebera auxílio de Tupá (OT 3.551-575). Mas Itajuba abranda a sua ira, lamentando o facto de nunca ter visto o maracá vazio, e que haveria de reparar o delito:

Cegou-nos Anhangá, diz Itajuba,

Fincando o maracá nos meus terreiros,

Cegou-nos certo! - nunca o vi sem honras!

Que o vira, bom piaga... oh!não se diga

Que um homem só, dos meus, perece à mingua,

(Quem quer que seja, quanto mais um Piaga_ 
Quando campeam tantos homens d'arco

Nas tabas de Itajuba, - tantas donas

$\mathrm{Na}$ cultura dos campos adestradas.

hoje mesmo farei que ao antro escuro

Caminhem tantos dons, tantas ofertas,

Que o teu santo mistério há de por força,

Quer queiras, quer não, dormir sobre elas! (OT 3.576-588)

Espera com as oferendas aplacar a ira dos deuses, exalta o conselho recebido, e, sem mais dizer, recolhe-se. $O$ poeta ainda menciona o alegre tumulto que se origina entre todos os membros da aldeia, quando se dispóem a cumprir a promessa. E assim encerra-se o terceiro canto, no qual, para Ackermann ${ }^{338}$, Gonçalves Dias lançou os fundamentos para o desenredo final de toda a epopeia.

$\mathrm{O}$ primeiro canto, a iniciar-se com bons indícios, com os primeiros sonhos a anunciarem boas-abastanças sobre os Timbiras, encerra-se com a dúvida infinitamente cruel, a esperança de que a rica oferenda aplaque a ira dos deuses. Mas os maus presságios ficaram ao longo do canto: o sonho de tristeza e morte de Japegoá; o semblante angustiado de Mojacá; o pressentimento de Itajuba semelhante ao de Japegoá; a segunda interpretação do Piaga.

$\mathrm{Na}$ esperança dos favores divinos, o canto melancólico havia de encerrar-se com alguma realização de felicidade, se não fossem as últimas palavras do próprio poeta:

Trabalho no prazer, prazer que moras

Dentro de tanto afá! festa que nasces

Sob auspícios tão maus, possa algum gênio,

Possa Tupã sorrir-te carinhoso,

E das alturas condoer-se amigo

Do triste, órfão de amor, e pai sem filho! ( T 3.602-607)

Não bastava que os presságios optimistas, no início do terceiro canto, sucumbissem ao pessimismo ao longo da narrativa. Este pessimismo é subtraído por um instante por uma esperança, por um novo optimismo no decorrer do poema; mas no encerramento, de uma vez por todas, o poeta elimina quaisquer eventuais agouros de felicidade, anunciando a morte inevitável do herói ausente.

${ }^{338}$ Ackermann 1964 121-122. 
O desfecho deste canto indica que os Timbiras iriam ao encontro de sua destruição. Tal desfecho era de facto planeado pelo poeta, cujo objectivo, de acordo com Henriques Leal ${ }^{339}$, era traçar uma série de quadros de lutas entre Gamelas e Timbiras repelidos de Tapuntapera, uma parte para Mearim e Itapecuru, e outra entrando pelo Amazonas, onde pereceria Itajuba, no cimo de uma copada árvore, picado por uma cobra coral.

Fica assim claro também o motivo pelo qual Gonçalves Dias insere neste canto a lamentação sobre a "América infeliz". Obviamente que não se espera outra coisa senão lágrimas e queixas, de um poeta que se denomina cantor modesto de um povo extinto.

O quarto canto leva-nos ao acampamento dos Gamelas. Este descortina-se improvisadamente, com uma alegre recepção feita a Jurucei, que se apresenta diante da tribo. As primeiras palavras de boas vindas parecem vislumbrar uma esperança em que ecoa uma expressão homérica: "o melífluo Timbira, cujos lábios destilam sons mais doces que os favos" (OT 4.2-3). Jurucei lança ao chão as suas armas partidas, como indicação de que era um mensageiro de paz (OT 4.21-24). A base psíquica em que se desenrola toda a cena vem exposta de diferentes modos e com muitos pormenores. Concomitantemente, o poeta revela os pensamentos que assaltam os Gamelas, ressaltando que a usada gravidade já na garganta a voz lhes retardava (OT 4.19-20) e que o modo deles é serem prudentes, graves e sisudos (OT 4.19-47).

Os títulos "fausto mensageiro, hóspede amigo, ledo núncio de paz" (OT 4.1, 5-6) e as figuras poéticas que descrevem a natureza (OT 4.9-13), assim como todas as decisóes que os Gamelas tomam acerca dos desígnios de Jurucei trazem um anúncio de otimismo. A natureza dissemina o mesmo otimismo e a luminosa e resplandecente beleza tropical respira paz e tranquilidade, criando uma atmosfera em que toda a cena se emoldura impecavelmente ${ }^{340}$.

Posteriormente, a atenção do poeta volta-se para Jurucei que, num monólogo, expốe como, à vista da massa compacta das inúmeras igaras, é levado a enaltecer as seivas aguerridas das duas naçôes (OT 4.75-77). Sobrevem-lhe prófuga lembrança das vicissitudes da guerra (OT 4.79) e finalmente impera no seu espírito a segurança na invencibilidade de Itajuba (OT 4.80-83).

${ }^{339}$ Ackermann 1964122.

${ }^{340}$ Ackermann 1964123. 
Segue-se uma analogia entre este solilóquio e a impressão causada nos Gamelas pela atitude heróica de Jurucei, que lembra àqueles a fatalidade do seu chefe, quando arriscou subjugar os Timbiras (OT 4.84-90). Enquanto o mensageiro "em banquete frugal2 desfruta das honrarias de hóspede ${ }^{341}$ (OT 4.91-104), Gurupema, o filho do malogrado cacique, preside o conselho de guerra. Dentre a alongada fileira dos guerreiros que acodem, destaca-se o formidável Caba-oçu; depois Jepiaba, "o forte entre os mais fortes"; Itapeba, o rival de Gurupema; e Oquema "que por si vale mil arcos", e muitos outros, cuja morte não foi sem glória (OT 4.146-147).

De acordo com Ackermann ${ }^{342}$, aqui se arraiga novamente uma daquelas cenas dramáticas tão eficientemente entretecidas na epopeia. Porque Jurucei traz à memória dos Gamelas a morte cruel do cacique, e isto incita os guerreiros à vingança (OT 4.148155). Gurupema começa a indagar a opiniāo dos camaradas para saber se consideram aceitáveis as condiçóes de aliança que supóe lhes sejam apresentadas (OT 4.155-161). A interrogação acende o descontentamento de Itapeba, que ameaça passar para a hoste do mais poderoso, "que sabe leis ditar" (OT 4.177-183). Depois da aprovação de Itapeba e da opinião de Oquena (OT 4.184-201), Gonçalves insere Caba-oçu, que, furioso com a atrocidade cometida pelo cacique Timbira, inflama o entusiasmo dos Gamelas. Estabelecida a unanimidade, Gurupema renuncia à sua condição de chefe, alistando-se, como simples combatente, na frente constituída.

Ackemann $^{343}$ estabelece uma analogia entre o descontente Japegoá do terceiro canto e a figura de Itapeba (OT 4.254256), mas o poeta assinala a atitude hostil diante de Gurupema. Para Ackermann, Gonçalves certamente teria idealizado um papelespecial para Itapeba. Porém, no quarto canto, faz menção dele apenas para dar maior relevo ao veemente entusiasmo dos guerreiros, que vem descrito logo de seguida. Para isto, o poeta introduz uma nova personagem, Tapuia, que, para Ackermann ${ }^{344}$, é uma analogia da figura de ocajá.

Tapuia, cujo apelido, "o forasteiro", vem amplamente justificado (OT 4.257-271), é um índio muito experiente e

${ }^{341}$ Costa 1934252.

342 Ackermann 1964123.

343 Ackermann 1964124.

${ }^{344}$ Ackermann 1964124. 
prudente, estimado como conselheiro de alto valor. Pronuncia um discurso que deve ser qualificado como obra prima de retórica; primeiro, fala de suas longas jornadas e das pelejas em que participou (OT 4.277-282); fala dos diversos caciques que conheceu, assegurando que nenhum deles jamais teria praticado acção de tal maneira ignominiosa como a que se trama, e manifesta logo de início a sua oposição (OT 4.282-290). Condena, em seguida, a insubordinação de Itapema (OT 4.291-293); previne o perigo de parecer ansioso e confessa que a sua sede de sangue já foi saciada com as lutas horrendas que empreendeu (OT 4.297302).

Tapuia, no seu discurso, declara o direito de Itajuba, e deposita no "rei das selvas" a responsabilidade pelas consequências de sua inveja, vaidade e cegueira (OT 4.304-314). Denuncia os Gamelas por serem insatisfeitos, apesar da sua grandeza e da sua opulência, dos recursos das suas flo estas e rios e do seu poderio belicoso. Repreende-os eticamente por quererem tirar, sem precisão, aos outros o que a eles é indispensável (OT 4.327-329). Nem a disposição dos Timbiras, de entregar ou não o cadáver do cacique vencido, pode depender, de acordo com Tapuia, da necessidade de fazer a guerra (OT 4.330-336).

Por fim, Tapuia propóe aos Gamelas que regressem para as suas tabas; Gurupema, no entanto, resolve esperar a decisão de Tupá, o que Tapuia também rejeita, asseverando que Tupá nega o seu auxílio aos imprudentes (OT 4.337-346).

De acordo com Ackermann ${ }^{345}$, o discurso de Tapuia utiliza todos os recursos do talento oratório e jurídico de Gonçalves Dias. O poeta emprega numerosas interrogaçóes retóricas, expondo o seu ponto de vista ético. $\mathrm{O}$ orador desenvolve aos poucos a sua sentença, a ponto de poder arriscar a proposta dos Gamelas renunciarem ao cadáver do malogrado cacique, o que, no entanto, contradiz um dos costumes indígenas mais sagrados.

$\mathrm{Na}$ transiçáo para a cena peremptória do quarto canto, Gonçalves volta-se para a natureza, a grande personagem auxiliar que actua ao lado de figuras que falam e agem. Menciona a sua simplicidade, isenta de quaisquer ornatos artificiais, mas também a sua majestade, e abre imediatamente a cena com a assembleia pacífica dos negociado es (OT 4.350-371).

Com um procedimento de saudação, apresentam-se um ao outro o representante dos Gamelas e o dos Timbiras.

${ }^{345}$ Ackermann 1964125. 
Literalmente, com insignificantes variações apenas, Jurucei transmite a mensagem do seu cacique, que em todas as alternativas descompassa as propostas de paz esperadas por Gurupema e por ele antecipadamente assinaladas na sua alocução inicial. Ambos falam da sua intenção de evitarem mais derramamento de sangue, com a diferença de Itajuba desprezar a glória de ter vencido sobre a nação perjura.

\author{
"Não ignavo temor a voz me embarga, \\ Emudeço de ver quáo mal conheces \\ Do filho de aguar os altos brios! \\ Esta a mensagem que por mim vos manda: \\ Três grandes tabas, onde heróis pululam, \\ Tantos e mais que nós, tanto e mais bravos, \\ Caídas a seus pés a voz lhe escutam. \\ Não quer dos vossos derramar mais sangue: \\ Tigre cevado em carnes palpitante, \\ Rejeita a fácil presa; nem o tenta \\ De perjuros haver troféus sem glória. \\ Em quanto pois a maça não sopesa, \\ Em quanto no carcaz dormem-lhe as setas \\ Imóveis - atendei! - cortai no bosque \\ Troncos robustos e frondosas palmas \\ E novas tabas construí no campo, \\ Onde o corpo caiu do rei das sevas, \\ Onde empastado inda enrubece a terra \\ Sangue daquele herói que vos infama! \\ Aquela briga enfim de dois, tamanhos, \\ Sinalai; porque estranho caminheiro \\ Amigas vendo e juntas nossas tabas \\ $\mathrm{E}$ a fé que usais guardar, sabendo, exclame: \\ Vejo um povo de heróis, e um grande chefe!"(OT 4.409-432)
}

A negação da guerra, o desejo de alcançar a paz através da aliança, ao invés do combate armado, donde saem os vencedores gloriosos, é por si um acto antiépico. Para o homem primitivo, a união pacífica era um sinal de fracasso, de medo da morte, medo do derramamento de sangue, e não havia, entre os povos primitivos, maior honra e glória do que perecer numa batalha.

A proposta de uniáo náo poderia ter validade, porque ela trairia as convençóes Gamelas, já que o seu cacique havia sucumbido à morte pelas máos do chefe Timbira, e a vingança 
era imprescindível numa tribo indígena americana ${ }^{346}$. A aparente esperança de dias de paz no seio das tribos rivais contrastava com um pessimismo incalculável, porque a guerra movia toda a vida das tribos. Portanto a proposta de Itajuba é por si um acto anti-heróico. Itajuba estava disposto a abdicar da glória de ter assassinado o chefe Gamela, a troco de um acordo de paz, a troco da submissão dos rebeldes. Por outro lado, o cacique Timbira tentava pela paz resguardar aquilo que lhe pertencia por direito.

No entanto, a proposta, que jamais deveria ter acontecido num poema desta natureza, é um ultraje para a honra dos Gamelas. Aos fujóes não restavam alternativas que não fossem o combate armado ou a entrega pacífica. Gurupema qualifica como desleal o duelo em que seu pai fora vencido, e aguarda a restituiçáo do cadáver. Itajuba exige o cumprimento do ajuste estipulado antes do duelo (OT 1.58-59), que consistia na subordinação dos Gamelas e fusão das duas tribos sob o seu comando. Ordena, além disso, que edifiquem novas tabas no local da peleja, as quais promulguem, no mesmo instante, como monumento triunfal, a sua glória.

A exigência de Gurupema de que lhe fosse restituído o cadáver do pai morto em combate, torna-se, até certo ponto, um refle o da conclusão da Ilíada, quando o rei Príamo se dirigiu junto às naus dos Aqueus, para negociar com Aquiles a devoluçáo do cadáver do filho morto em duelo. Se o interesse de Gonçalves era distanciar-se o mais possível das convençóes épicas dos gregos, romanos e portugueses, verdade se diga que o poeta falhou na sua intenção. Porque a sua história é recontada, e todas as vezes que uma história é recontada, ganha uma versão diferente. Portanto, Os Timbiras tornam-se imitação das tais obras.

Por causa da sua arrogância bem como da acção a que se deixa levar - atravessa, com a finalidade de demonstrar a sua habilidade no manejo das armas, e certamente para manifestar o seu respeito e a sua raiva, um cenembi, "ave sagrada», que descansa sobre a copa duma árvore, e isto no domínio de Itajuba (OT 4. 462479) - Gurupema, que, até então, havia apresentado um caráter discrepante, mesquinho e inferior à posição que ocupa, induz o mensageiro Timbira a lançar contra ele gravíssimas acusaçóes, expressóes de escárnio, maldiçóes e a iminência de terríveis retaliaçóes (OT 4.480-502). A fim de mostrar o efeito produzido pelas acusaçóes de Jurucei, Gonçalves inclui, de forma concisa,

${ }^{346}$ Fernandes 1989262. 
um acontecimento significati o: uma flecha, disparada por mão desconhecida, crava o braço do emissário quando ainda falava (OT 4.502-504). Os últimos versos do canto evidenciariam o inopinado desaparecimento do emissário Timbira e os esforços do "timorato" Gurupema por descobrir o autor do incidente.

As últimas palavras de Jurucei manifestam uma bravura diante dos inimigos, semelhante à que devia manifestar o herói de I-Juca Pirama, que nega, para enfim triunfar numa forma dramática pela honra e pela glória, não apenas suas, mas também da nação à qual pertencia. Jurucei estava certo de que os bravos Timbiras haveriam de vingar o seu desaparecimento. Incita, por isso, os Gamelas a organizarem-se para o combate ou a fugir, prolongando assim a morte da nação (OT 4.505-520). As palavras de Jurucei manifestam, sem sombra de dúvidas, a bravura, a glória e a impregnação poderosa das tribos Timbiras pela honra, acto que por si só é um contragolpe à sua condição de emissário da paz. Mas o poeta evidencia a fraqueza de Gurupema:

E como o raio em noite escura

Cegou, desapareceu! De timorato

Procura Gurupema o autor do crime,

E autor lhe não descobre; inquire... embalde!

Ninguém foi, ninguém sabe, e todos viram. (OT 4.520-524)

A figura de Itajuba ocupa a posição central e predominante nos quatro cantos da epopeia. Tudo o que dele se narra e relata, forma, no seu conjunto, a imagem de um homem prendado de todos os requisitos de um homem que nasceu para ser cacique. Demonstra força e habilidade; o seu espírito de justiça, ferido pela postergação dos acordos, é a base sobre a qual se erige o seu plano de vingança. Está de tal maneira compenetrado em ser o primeiro e o melhor, que impóe aos outros esta convicção (OT 1.356-376), ainda que seja necessário derramar sangue de irmáos. Por sua vez, o lado sentimental do herói está manifesto no canto a Coema e na amizade que devota a Jatir.

Para Ackermann ${ }^{347}$, a caracterização dos dois caciques Gamelas dá um brilho mais vivo ao relevo de Itajuba. Apresentam-se como indivíduos brutais, presunçosos, atrevidos e de prudência e dignidade muito inferior a Itajuba. Basta vermos como sucedeu a morte do primeiro cacique, ou atentarmos no caso de Gurupema,

${ }^{347}$ Ackermann 1964127. 
que tolera franca insubordinação e suporta a zombaria de Itapeba; dá aos homens o direito de conservarem ou não o seu posto de chefe, como se fosse um democrata. As últimas palavras do poema denunciam a fraqueza do inimigo de Itajuba. Gurupema é, de facto, um herói antiépico, apresentando-se muito inferior àquele que terá de combater; os seus comandados são inferiores em número aos Timbiras, quando, numa epopeia, o normal são os combates numerosos, em que a grandeza do exército derrotado consiste na elevação do exército vencedor. Mas Gonçalves optou por um modelo mais próximo da Eneida, contrariando a proposta de recriar uma "Ilíada Brasileira". Enquanto Itajuba mantém seguras as rédeas do seu governo, Gurupema deixa curso livre aos acontecimentos. Itajuba convoca os seus homens para uma revista geral e Gurupema reúne os seus guerreiros para um concílio.

As duas tribos apresentam diferenças primordiais. São claramente perceptíveis através de três episódios (OT 1.253265; 1.281-296; 4.118-136). O primeiro refere-se a Jucá, valente Timbira, que, livrando-se de grave perigo, caçou uma onça, com cuja pele se enfeita. O segundo é de Japi, que, no momento de maior expectação da caça, quer atirar a sua flecha a um furioso javali e que, surpreendido pelo toque "membi" de Itajuba, abandona a presa, acudindo obediente ao local de reuniáo dos guerreiros. $\mathrm{O}$ terceiro episódio que ocorre no seio da nação Gamela é bem diverso dos anteriores ${ }^{348}$. Caca-oçu apresenta-se com uma maneira de lutar bestial e sanguinária. É um indivíduo de indescritível indignidade: o poeta recorda uma cena repugnante, na qual o feroz Gamela, depois de despedaçar o crânio de um prisioneiro, bebe o sangue e devora o cérebro da vítima.

Para Ackermann ${ }^{349}$, o poeta possui uma franca simpatia pelos Timbiras, opondo, portanto, uma aldeia de caçadores, obedientes, confiantes em seu cacique, recorrendo ao combate somente quando se trata de proteger a sua honra e o seu território, a uma tribo de guerreiros sedenta de glória e em parte caracterizada como soturna e retraída que invade território estrangeiro sem necessidade, seguindo e aplaudindo o rival insubmisso do seu cacique.

Além do cacique, outra figura muito importante na colectividade indígena é o Piaga, sacerdote da tribo. Na epopeia, Gonçalves retrata-o num quadro de admirável grandeza:

348 Ackermann 1964127.

${ }^{349}$ Ackermann 1964128. 
Sai o piaga no entanto da caverna,

Que nunca humanos olhos penetraram

Com ligeiro cendal os rins aperta,

Cocar de escuras plumas se debruça

Da fronte, em que se enxerga em fundas rugas

$\mathrm{O}$ tenaz pensamento afigurad .

Cercam-lhe os pulsos cascavéis loquazes,

Respondem outros, no tripúdio sacro

Dos pés. Vem majestoso, e grave, e cheio

Do Deus, que o peito seu, tão fraco, habita.

E em quanto o fumo lhe volteia em torno,

Como neblina em torno ao sol que nasce,

Ruidoso maracá nas mãos sustenta,

Solta do sacro rito os sons cadentes. (OT 2.69-82)

Gonçalves apresenta-o no exercício de práticas rituais: transmitindo o dom da invulnerabilidade do corpo de Jaguar morto ao seu filho Itajuba (OT 1.12-17); na qualidade de medianeiro directo entre Tupã e os irmãos da tribo, implorando protecção e sonhos favoráveis e esconjurando o poder do mau Anhangá (OT 2.249-259). O poeta ainda refere-se à tamanha consideração que gozavam o seu conselho e as suas admoestaçóes (OT 3.442-457).

Mas o Piaga também vive o seu momento antiépico: no instante em que deveria rogar pela salvação da tribo dos males prenunciados nas visóes, o sacerdote renuncia ao seu ofício. Renuncia a ser consultado pelos membros da tribo, alegando a falta de complacência dos seus membros:

Consultemos o piaga: às vezes pode

O santo velho, serenando o ibaque,

Amigo bom tornar o Deus malquisto."

Mas ora não! - responde o piaga iroso.

"Só quando ruge a negra tempestade,

"Só quando a fúria d'Anhangá fuzila

Raios do escuro céu na terra aflita

Do piaga vos lembrais?Tanta lembrança,

Tarda e fatal, guerreiros! Quantas vezes

Não fui, eu mesmo, nos terreiros vossos

Fincar o santo maracá? Debalde,

Debalde o fui, que à noite $o$ achava sempre 
Sem oferta, que aos Deuses tanto prazem!

$\mathrm{Nu}$ e despido o vi, como ora o vedes.

(E assim dizendo mostra o sacrossanto

Mistério, que de irado pareceu-lhes

Soltar mais rouco som no seu rugido)

Quem de vós se lembrou que o santo Piaga

$\mathrm{Na}$ lapa dos rochedos se mirrava

Apura míngua? Só Tupã, que ao velho

Deu não sentir os dentes aguçados

Da fome, que por dentro o remordia,

E mais cruel, passada entre os seus filhos!" ( T 3.554-575)

Em face do ego ferido, o Piaga torna-se incapaz de oferecer o seu auxílio aos Timbiras. Também assim se teria comportado Aquiles, raivoso. Diante do episódio de Briseida com Agamémnon, o herói argivo retirou-se da batalha, e a sua remoçáo causou duras provas aos guerreiros gregos. $\mathrm{O}$ orgulho de Aquiles e a presunção de Agamémnon foram reunidos no Piaga gonçalvino. No mundo grego, a hybris era o pecado por excelência contra a saúde cósmica e política; a ira de Aquiles, a soberba de Agamémnon são exemplos deste acontecimento. Por outro lado, a ira e a soberba do Piaga mantêm o mesmo desempenho, porque sem o seu auxílio, a ruína dos Timbiras estava decretada.

A personalidade de Jatir também se revela antiépica pelas descrições entretecidas nos três primeiros cantos. O seu nome aparece pela primeira vez na inspecção dos guerreiros. Itajuba tributa-lhe uma grande amizade (OT 1.297-304). A sua vocação para a solidão é aleivosamente interpretada, por um aguerrido, como ambição desregrada (OT 1.305-309); Ogib defende a reputação do filho, comparando-o ao condor que, ao contrário dos "anus" e "caitetus", se eleva a solitárias alturas. Mas, ao elevar a superioridade de Jatir acima da de Itajuba, Ogib comete uma iniquidade, porque um combatente jamais poderia sobrepujar a honra do seu chefe. Ao exaltar o filho em superior grandeza aos demais Timbiras, Ogib incita no cacique a ira; Itajuba exalta o carácter heróico de Jatir, mas reclama a superioridade para si próprio, repelindo assim a diminuição com que o velho o procura ferir. $\mathrm{O}$ valor guerreiro de Jatir vem claramente caracterizado na narrativa de Mojacá (OT 3.517-545).

Para Ackermann ${ }^{350}$, a descrição de Jatir é lúgubre e fantástica, chamando-nos a atenção para o diálogo entre Ogib e Piaíba

${ }^{350}$ Ackermann 1964129. 
que, ao lado da oração do Piaga e da canção dirigida a Coema, compóem o segundo canto. O panorama é peculiar de uma antiepopeia: a taba está escura, o fogo apagado. Na concepção de determinadas imagens que se apresentam à consciência, não interferem, de imediato, o sentido ocular, e a percepçáo depende excepcionalmente da audição e do tacto, dois sentidos de conhecimentos facilmente ilusórios ${ }^{351}$. Por conseguinte, Gonçalves já prepara o terreno incerto para o misterioso e o sinistro. Acrescenta a disposição psíquica e mental das personagens em questáo: o pai assaz angustiado e apreensivo, que náo pode conciliar o sono, e Piaíba, atribulado pela dor das chagas, de mente perturbada e acossado de frenesi, supondo o velho adormecido.

$\mathrm{O}$ "canto de morte" em homenagem a Coema representa o arcabouço de toda a cena ${ }^{352}$. No seu monólogo, Piaíba fala de seu encontro nocturno com a morte, e do apelo desta a Ogib de ir encontrá-la também, ao anoitecer, junto à sepultura de Coema. A imagem da morte comparada a uma virgem bela e insensível é uma analogia da própria descrição que o poeta fez em Quadras da minha vida, quando a morte tấo insolente é vista como a virtude daqueles que a alcançam. Piaíba desejava-a ardentemente. $\mathrm{O}$ seu anseio é semelhante ao do próprio Gonçalves:

Laje fria dos mortos! quem me dera

Gozar do teu descanso, ir asilar-me

Sob o teu santo horror, e nessas trevas

Do bulício do mundo ir esconder-me!

Oh! laje dos sepulcros! quem me desse

No teu silêncio fundo asilo eterno!

Aí não pulsa o coração, nem sente

Martírios de viver quem já não vive.

O excerto do poema Quadras da minha vida contém os lamentos do poeta que conviveu com inúmeras angústias, chegando ao ponto de pensar em suicídio. As queixas de Piaíba tornam-se análogas às lamúrias do poeta.

Eu via a morte: vi-a bem de perto

Em hora má!

$\mathrm{Vi}^{\prime}$-a de perto, não me quis consigo,

${ }^{351}$ Ackermann 1964129.

352 Ackermann 1964129. 
Por ser tão má.

Só não tem coração, dizem os velhos,

E é bem de ver;

Que, se o tivera, me daria a morte,

Que é meu querer.

Não quis matar-me; mas é bem formosa;

Eu vi-a bem:

É como a virgem, que não tem amores,

Nem ódios tem. (OT 2.372-383)

Gonçalves deseja o descanso na fria lousa e encontra na morte uma espécie de asilo, onde estaria escondido do bulício do mundo e dos martírios de viver como quem já não vive. Piaíba descobre a formosura da morte, mas derrama o seu lamento sobre a falta de coração da morte, o que tornaria o seu depauperamento possível. Lamenta a decisão da morte de não querer matá-lo, acusando-a de impiedade. Por fim, Piaíba transfere este desejo para o velho Ogib, pois admite que a ele fosse agradável a mensagem (OT 2.398-401).

Piaíba expóe uma cadeia de opiniões e consideraçóes contraditórias sobre a morte, umas em aquiescência, e outras em discrepância com o que dela se habitua a dizer. No encerramento do seu canto, Piaíba assevera náo perceber porque se queixa da morte, porquanto ele próprio ignora a sua idade. No decorrer da cena, o demente encontra-se perto da fogueira extinta, remexe a cinza fria, mas está sob a ilusão de se estar aquecendo ao fogo e acalenta o desejo de não ser expulso daí. Em dada circunstância iça a voz, trepidante, mas volta logo aos seus obscuros pensamentos. Sem dar por fé da inquirição de Ogib, que o interroga constantemente, ele torna a repetir: ora os versos iniciais do canto da morte, ora as lamentaçóes sobre as suas dores, com as quais principiou o monólogo.

$\mathrm{O}$ cunho de insegurança, tão sensivelmente apregoado, no conteúdo, na ambientação e na configuração, exacerba a ansiedade no outro personagem, de tal maneira que o poeta chega a afiançar que um delírio quase igual lhe castiga as ideias transtornadas ${ }^{353}$ (OT 2.390, 391). À tensão de espírito e ao assombro de Ogib referem-se os versos que antecedem e interrompem o canto de Piaíba. Gestos e palavras acompanham a obstinação de Ogib, ansioso por notícias do paradeiro e do estado em que se encontra o filho Jatir. Estende a mão e toca no corpo daquele que vaguea

353 Ackermann 1964130. 
pela noite, que tirita de frio e humidade; depois ergue o corpo, salta da rede; Ogib ouve a canção e sente frio, um frio que não é sentido apenas fisicamente - o frio da morte, o frio do calafrio ${ }^{354}$. Gonçalves, enfim, conclui a cena com o pensamento de Ogib voltado para o filho distante. Desesperado, Ogib pede a morte para o velho demente, enquanto implora para si a vida, até que tenha tido a ventura de rever Jatir.

Toda a obra de Gonçalves Dias torna-se antiépica, porque, por detrás de uma felicidade aparente, há sempre um lado taciturno e lúgubre; Os Timbiras estão repletos de trechos líricos cheios de sombras nocturnas ${ }^{355}$. Ogib mantém as esperanças de encontrar o filho, louva-o, exalta-o, mas também demonstra o seu desânimo, chegando a desesperar quando se apercebe de que o filho possa estar prisioneiro em alguma tribo inimiga (OT 3.545-550). No conjunto de toda a epopeia gonçalvina o sopro da antiepopeia é forte. É no silêncio profundo do cair da noite que os guerreiros retornam às suas tabas, tranquilos e confiantes nas capacidades do seu cacique. Assim como a fresca manhá anuncia um belo dia, palpita neles a esperança de que a interpretação de seus sonhos lhes pressagia êxito e vitórias. A natureza espelha a mesma paz que os Gamelas esperam que lhes traga o emissário Jurucei, e o riacho está triste, porque deve levar as suas águas calmas ao rio e à torrente turbulenta (OT 4.26-38). Mas, por detrás dessa felicidade aparente, está a destruiçáo: o poeta questiona quantos veriam depois daquela aurora uma nova alvorada. A paz que os Gamelas esperam não chegaria a vir pois o emissário tornar-se-ia presa dos Gamelas. O riacho não é um pormenor, como diria Ackermann ${ }^{356}$, mas é fundamental para a interpretação da antiepopeia: junto com as águas que caminhavam para o rio, escapava-se a esperança de dias melhores, escapava-se a esperança de paz.

A morte é a única esperança que podemos asseverar das obras de Gonçalves Dias; se no primeiro canto questiona quantos veriam a nova aurora (OT 1.387-391), no segundo, o poeta dá a descrição da aldeia Timbira, estabelece um confronto entre os habitantes das rudes palhoças e os que moram nas construçóes de pedra da civilização europeia, concluindo com a igualdade absoluta de ambos, diante da morte e das humanas atribuiçóes e esperanças (OT 2.39-55).

${ }^{354}$ Ricardo 196465.

${ }^{355}$ Coutinho 198690.

${ }^{356}$ Ackermann 1964132. 
Para Ackermann ${ }^{357}$, os noventa e nove versos do terceiro canto em que Gonçalves, intimamente embriagado pela ruína da "América infeliz" (OT 3.26-125), - talvez a mais bela passagem de toda a epopeia - fala de uma época como denunciante e intercessor do povo aniquilado. "Enuncia aqui in persona, e de forma mais desenvolvida, as mesmas idéias que em Deprecação, pôs na boca do anciáo tupi ${ }^{358}$." O poeta queixa-se da destruição das flo estas nativas e da escravização dos íncolas, fazendo um protesto, quase uma maldição, contra a Europa, a dinamizadora da destruição no seio do novo mundo. O poeta nostálgico evoca o tempo feliz anterior à invasão do europeu ganancioso, e rememora as lutas travadas entre os holandeses, os portugueses, os franceses e os espanhóis, por causa da cobiça desenfreada. A acusação do poeta náo se dirige apenas aos invasores. É contra o filho de aguar que pesa a mais grave acusação:

Fera bravia procurava asilo

Nas fundas matas, e na praia o monstro

Marinho, a quem o mar, já não seguro

Reparo contra a fôrça e indústria humana,

Lançava alheio e pávido na areia?

Agudas setas, válidos tacapes

Fabricavam talvez!... ai não... capelas,

Capelas enastravam para ornato

Do vencedor; - grinaldas penduravam

Dos alindados tetos, por que vissem

Os forasteiros, que os paternos ossos

Deixando atrás, sem manitôs vagavam,

Os filhos de Tupã como os hospedam

$\mathrm{Na}$ terra, a que Tupã não dera ferros! (OT 3.110-124)

Em vez de fabricarem setas agudas e tacapes para a defesa da terra natal, os comandados de Itajuba erroneamente fabricavam ornatos a fim de saudarem os estrangeiros. E seria essa admiração pelos estrangeiros a causa da ruína profunda no seio de sua tribo (Sebreli ${ }^{359}$ dá o exemplo clássico de que esta também seria a causa da destruição das tribos mexicanas:

El aislamiento, por otra parte, llevó a los indígenas americanos a la incapacidad para assimilar a los extraños, para comprenderlos, para

${ }^{357}$ Ackermann 1964133.

358 Ackermann 1964133.

359 Sebreli 199156. 
concebirlos siquiera como seres humanos. Cortés comprendía a los aztecas, aunque no los quisiera, los aztecas no comprendíam a los espańoles. Desde el mismo momento en que confundieron a los conquistadores con dioses o semidioses ya estaban derrotados).

As colónias dos Timbiras eram de tal forma desunidas que, para os colonizadores, era esta a grande vitória, porque se, pelo contrário, os índios se tivessem unido num interesse comum de «expulsar o invasor», certamente teriam os colonizadores maiores dificuldades em conquistar a terra. No entanto, os indígenas desconheciam a importância desta união. Os índios gostavam mais das caçadas e da guerra, não estando de modo algum preocupados com o colonizador que, afinal, em muitas ocasiôes, unia-se em favor da destruição de uma aldeia, e com isso diminuía o número de aldeias, enfraquecendo consequentemente o elemento indígena, dono da terra ${ }^{360}$.

A epopeia de Gonçalves, por fim, não poderia deixar de ser um canto de tristeza, de dores, de melancolia, de nostalgia de um tempo irrecuperável. Mais que isso, o sentimento de perda para o invasor que, potente, impóe-se sobre os íncolas, um sentimento agravado pela recente independência brasileira, quando ainda estava na mente dos brasileiros a lembrançapresente do colonizador. Gonçalves provinha de uma regiấo repleta de conflitos entre brasileiros e portugueses, encontrando nisso o campo fértil para disseminar o seu sentimento, apesar de sua herança paternal estar intimamente ligada a Portugal.

Por fim, não bastante para a composição de uma antiepopeia, Gonçalves comete um "delito": ao erigir a superioridade de Itajuba diante dos caciques Gamelas, o poeta subtrai em grande parte as qualidades de chefes e guerreiros. Nem Gurupema, nem o seu pai morto em combate com o filho de Jaguar são de igual destreza, comparados ao chefe Timbira.

Nenhum dos dois possui as qualidades de chefe e soldado de que dispóe Tabira no poema do mesmo cognome. A subtracção das qualidades dos caciques Gamelas em face do cacique Timbira compromete o objectivo de construir uma "Ilíada Brasileira". O que Gonçalves nos entrega, afinal, não deixa de ser uma "Eneida Brasileira”, porque nesta, Virgílio dá a superioridade a Eneias, despojando Turno de toda a protecção divina e colocando-os em face de um combate injusto.

${ }^{360}$ Asanha 19849. 
Aparentemente, Gurupema não se encontra à altura de combater com Itajuba. A forma apreensiva com que o cacique Gamela encerra o quarto canto, à procura daquele que desferiu a seta sobre Jurucei, demonstra a fraqueza do chefe. Gurupema estava longe das convençóes de uma morte cravejada de setas, caminhando imponente diante dos inimigos, arrancando uma seta que atingira o olho em cheio e exibindo-a com o membro, como se fora um troféu, incitando com palavras à ira no inimigo, ainda que estivesse em situação de absoluto perigo, semelhante ao que fi era Tabira. Gurupema, aliás, demonstra ainda ser inferior a seu pai, que foi capaz de convidar Itajuba para um duelo directo. Apesar de cega, a decisáo do cacique Gamela é também, por si, um acto heróico, porque prefere combater e morrer pela sua tribo, evitando o derramamento de sangue de muitos. Para Bowra ${ }^{361}$, o herói clássico que sacrifica a vida adquire a glória imortal e, de facto, a lembrança da morte impiedosa do cacique permaneceu viva na memória dos Gamelas, a ponto de, em concílio, alguns lembrarem da necessidade de vingança.

O poema encerra com a apreensão de Gurupema. Gonçalves teria desejado compor uma epopeia com dezasseis cantos. No entanto, o restante afundou-se no oceano com o vate maranhense. Foi um acontecimento trágico para o Brasil, que ficou assim privado do mais elevado monumento literário do indianismo que até hoje foi erigido ${ }^{362}$.

O poeta optou por cantar os Timbiras, obviamente porque queria elevá-los moralmente e espiritualmente; conforme Ackermann ${ }^{363}$, os tupis eram o grupo de maior elevação moral de entre todas as tribos, contrastando sobretudo com os Tapuias, habitantes do interior, a quem os Timbiras pertenciam. E, em meio das narraçóes, surgem as palavras do poeta:

Trabalho no prazer, prazer que moras

Dentro de afä! Festa que nasces

Sob auspícios tâo maus, possa algum gênio,

Possa Tupã sorrir-te carinhoso,

E das alturas condoer-se amigo

Do triste, órfāo de amor, e pai sem filho! ( T 3.602-607)

${ }^{361}$ Bowra 196660.

362 Ackermann 1964134.

363 Ackermann 1964103. 
Isto indica que os Timbiras vão de encontro à sua própria destruição; de acordo com Henriques Leal, esta era a proposição de Gonçalves Dias ${ }^{364}$. Eis o resumo apresentado pelo amigo mais próximo e único que lera as partes perdidas do poema:

De pós o encontro das duas tribos inimigas, saem os gamelas vencedores da pugna e são repelidos os timbiras de Tapuitapera (Alcântara), parte recalcados para o Mearim e Itapecuru, e o grosso da tribo, abeirando a costa da Província, interna-se pelo Amazonas, onde se tresmalha, parecendo o chefe que ao acolher-se no cimo de uma copada árvore onde procurava abrigar-se de uma bandeira de resgate é aí picado por uma cobra coral ${ }^{365}$.

De facto, as populaçóes indígenas foram relegadas para o interior do país, longe do alcance dos engenhos e das fazendas ${ }^{366}$. Gonçalves, com louvor, faz uso da verdade histórica quando necessário, para recriar a verdade poética, embora não faça disso o topos da sua obra, porque a verdade poética é o que prevalece. A destruição do índio, conforme se percebe ao longo de toda a obra gonçalvina, deve-se à sua insubmissão ao regime português, de acordo com Sebreli ${ }^{367}$ :

Los antropólogos han mostrado que las sociedades muy primitivas que no han pasado por la revolución agrícola son impossibles de incorporar al mundo civilizado. La integración forzosa suponía um esfuerzo excesivo y los llevaba a la muerte.

É no índio extinto, no homem primitivo e bárbaro, no homem relegado pela sociedade europeia, que Gonçalves derrama o seu canto de consternação e de dor, uma estilização nostálgica daquilo que não se deixa mais cantar.

${ }^{364}$ Ackermann 1964122.

365 Coutinho 198691.

366 Sodré 1969265.

367 Sebreli 199164. 


\section{CONSIDERAÇÓES FINAIS}

Virgílio estava consciente da sua responsabilidade social como poeta e queria deixar, aos Romanos do seu tempo, uma mensagem esperançosa: esperança num futuro de paz, numa nova civilização, num homem, talvez. E que deixava ele? Uma obra estranha, percorrida de ambiguidade, em que os vencedores e vencidos surgiam irmanados pelo sofrimento, em que os próprios deuses se vergavam ao peso da frustração ${ }^{1}$.

Para Di Cesare2: "The poem ends in an uneasy truce, between power and justice, between history and humanity, between arma and pietas." Se olharmos para a origem, teremos um conto interminável, já que nunca se encontram verdadeiros aborígenes; os habitantes vieram sempre de outra parte, "todos los nativos fueron alguna vez extranjeros ${ }^{3}$."

Para Friedrich Schiller ${ }^{4}$, a poesia romântica teria perdido a ingenuidade, aquele nexo imediato com a origem das sensaçóes que caracterizavam as literaturas antigas como modelos de clareza e vigor; tornou-se sentimental, dobrou-se sobre si mesma e alargou o hiato entre a consciência e o mundo. Subjectivismo e ironia preencheram esta lacuna.

Machado de Assis ${ }^{5}$ celebra num poema a vida de Gonçalves Dias. A referida obra centra-se num facto biográfico, que acaba por se transformar em emblema de desastre e incompletude. $\mathrm{O}$ autor dos famosos versos - "Não permita Deus que eu morra,/ Sem que eu volte para lá" - morreu sem alcançar o solo da sua origem, embora já dele se aproximasse. A morte de Gonçalves Dias - com um livro inacabado e fracassado no seu intento de voltar à pátria - adquirem, no texto de Machado de Assis, amplas ressonâncias simbólicas, ligadas à impossibilidade do fechamento do ciclo, tal como ocorre nas travessias épicas. Para sublinhar tais ligaçóes, Machado lança máo de um contraponto e inicia o seu poema evocando a vida de Luís de Camóes.

\footnotetext{
${ }^{1}$ V. Pereira 1992 78-79.

2 Di Cesare 1974239.

${ }^{3}$ Sebreli 199164.

${ }^{4}$ Apud Bosi 1978245.

${ }^{5}$ Longo 200644.
} 
Com a morte prematura de Gonçalves Dias, e como os povos indígenas pereceram, as possibilidades do canto heróico que os consagra também parecem ameaçadas de extinção junto com o poeta - a despeito da vontade de poder que a todos lança, procurando lutar contra as suas tormentas ${ }^{6}$.

Durante o segundo ano da faculdade, Gonçalves Dias escrevera grande parte de um romance em que o próprio figura a e que se intitulava Memórias de Agapito Goiaba. De acordo com Henriques Leal, era composto de três grossos volumes, que o poeta queimou quando esteve na Europa, em 1854, por envolver factos que respeitava a outros que já não viviam ${ }^{7}$. Dessa extensa obra restaram três capítulos que foram publicados no Arquivo, no Maranhão, no Tomo III das Obras Póstumas ${ }^{8}$. Deste fragmento, Souza Pinto destaca um paralelismo que o poeta constrói entre a mata brasileira e os salgueirais conimbricenses, que estáo prefigurados no vigésimo capítulo, cujo título é Uma página de Álbum:

Se já viajastes pelas nossas flo estas do Brasil, tereis, ao anoitecer, parado muitas vezes em algum cabeço pouco elevado, para restaurar os membros fatigados. Sentistes a magestade da solidão das selvas no rumorejar crescente, imenso, inexprimível, dos colossos vegetais, nas variedades das fôlhas, de flo es e de arruídos, e na fôrça da vida que aí se revela debaixo de todas as formas. Talvez se vos figurasse a cada instante ouvir o som de alguma catadupa, como que se ela se arrojasse do píncaro de um rochedo ao fundo de um precipício, - talvez se vos figurasse ouvir a cada instante, no rugir compassado e solene das fôlhas das palmeiras, o arruído de mar longínquo quebrando-se furioso contra os escolhos da praia. Então comprehendestes a poesia das selvas, e a beleza selvagem do viver dos nossos índios; e, comtudo, ainda não podeis conjecturar que melodia exalam os salgueiros do Mondego embalados pela viração do oeste. $\mathrm{O}$ sussurrar das nossas matas é forte e magestoso como o rugir do oceano, o ciciar dos salgueiros é doce como um suspiro de virgem? .

Gonçalves, no entanto, destruiu quase toda a sua obra.

Mas Gonçalves soube produzir um novo indianismo. E no seu indianismo, é o índio quem sistematicamente olha o branco ${ }^{10}$.

${ }^{6}$ Longo 200648.

7 Souza Pinto 1931 9; Ackermann 1964 21; Ricardo 1964153.

${ }^{8}$ Souza Pinto 1931 10; Ackermann 196421.

${ }^{9}$ Souza Pinto 193110.

${ }^{10}$ Marques 2006180. 
Mas Bosi deixa-nos claro: a voz do poeta brasileiro culto soa na boca do Piaga que recorre ao imaginário bíblico para predizer o fim do mundo ${ }^{11}$. A sua prefiguração parece procurar um optimismo dentro de um pessimismo. $\mathrm{O}$ poeta sente-se inferior, é mestiço, possui baixa estatura; como se não bastasse, provém de um país recém-colonizado que alcançara a independência política havia pouco tempo. Estava na metrópole que durante três séculos inteiros governara a sua terra natal. Embora estivesse na pátria de seu pai, parecia, pelo menos literariamente, estar distante de sua terra natal ${ }^{12}$. No meio deste sentimento de abandono, de mágoa, "de fio de esperança que a distância adelgaça ${ }^{13}$ ", o poeta escreve a mais célebre de suas poesias, também tida como a primeira das Poesias americanas: Canção do Exílio, que, segundo Henriques Leal, se encontrava num dos capítulos das Memórias de Agapito

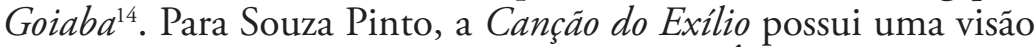
entristecida e aformoseada da pátria tropical. É uma afirmação de americanidade e de brasileirismo ${ }^{15}$ - sentimento que faria o poeta buscar a melhor americanidade possível, o melhor brasileirismo, que lhe fosse original, daí o indianismo.

No Velho Mundo, o grande elo que prende os homens é o sangue nacional ${ }^{16}$. A América é o Novo Mundo. $O$ factor primário de nacionalidade deixa de ser a raça e passa a ser a terra ${ }^{17}$. E isto está na Canção do Exílio. Este vínculo à terra é tão forte que, em alguns países americanos, os nacionais perdem os seus direitos quando deixam de viver lá por muito tempo ${ }^{18}$; e já em alguns países, independentemente da nacionalidade dos pais, os nascidos em solo nacional adquirem o direito de nacionalidade. No indianismo, Gonçalves tenta estabelecer o elo principal, que estava entre os europeus: a raça como factor principal de nacionalidade. É por isso que o poeta tem de usar o índio, a única raça genuína daquelas terras, já que os demais viriam de territórios do velho mundo.

O pessimismo encontra em Gonçalves a fertilidade de que precisa para evoluir. Como se não bastassem a origem humilde

${ }^{11}$ Bosi 2001185.

12 Souza Pinto 193110.

13 Souza Pinto 193111.

14 Souza Pinto 193111.

15 Souza Pinto 193112.

${ }^{16}$ Souza Pinto 193112.

${ }^{17}$ Souza Pinto 193112.

${ }^{18}$ Souza Pinto 193112. 
e os problemas financei os dos tempos de faculdade, o poeta, grande amoroso, diante do altar do amor, sobre o qual o seu coração ardeu incansavelmente ${ }^{19}$, declara entre outras obras suas paixóes. Entre os mais belos poemas destacamos: Se se morre de amor, e Ainda uma vez - Adeus. Na sua lírica amorosa, o poeta demonstra a inquietude do desejo sentimental, subitamente apaixonadiço, ávido de paixão, sem que só uma vez o amor o galardoasse dignamente ${ }^{20}$.

No entanto, Gonçalves falha como poeta. O seu grande projecto era compor uma epopeia. Os Timbiras, que para Souza Pinto, «apesar de fragmentário", é o mais belo dos poemas indianistas ${ }^{21}$, ficou inacabado; numa carta de mil e oitocentos e quarenta e sete, deixa claro a um amigo o seu objectivo e chega a anunciar elementos pitorescos, americanos, que utilizaria no poema: imaginava um poema com magotes de tigres, quatis, cascavéis; mangueiras, jabuticabeiras, jequitibás, ipês arrogantes, sapucaieiras, jambeiros, palmeiras, guerreiros diabólicos, mulheres feiticeiras; sapos e jacarés. Define a futura obra como "gênesis americano" e "Ilíada brasileira"22, "criação recriada". Os acontecimentos iniciariam no Maranhão e terminariam no Amazonas, com a dispersão dos Timbiras as guerras entre eles e também contra os portugueses ${ }^{23}$.

De acordo com Henriques Leal, entre outras produçóes literárias,. Gonçalves Dias trazia consigo, na viagem para o Brasil, os dez cantos inéditos de Os Timbiras. De acordo com Moisés $^{24}$, a epopeia teria dezasseis cantos que constituíriam ao todo três anos de labor. Mas o poeta naufraga e com ele a sua obra ${ }^{25}$. Reza a lenda que Camóes ${ }^{26}$ nadou para salvar a sua primeira versão de Os Lusíadas. Do outro lado, o poeta brasileiro não teve a mesma sorte, não escapando nem a própria vida, deixando do seu legado uma quantidade relativamente diminuta de poesias, pela brevidade da vida, pela morte trágica.

O poeta pretendia ainda escrever a história dos Jesuítas no Brasil. Declarava que seria a história brasileira como nunca antes

\footnotetext{
19 Souza Pinto 193113.

${ }^{20}$ Souza Pinto 193113.

${ }^{21}$ Souza Pinto 192819.

22 Moisés 198936.

${ }^{23}$ Franchetti 200762.

${ }^{24}$ Moisés 1989 36; Coutinho 1986 86; Ricardo 1964 66; Cândido 199385.

${ }^{25}$ Ackermann 196427.

${ }^{26}$ Ackermann 1964134.
} 
tinham escrito; mas também falhou no seu objectivo de escrevê-la. Sabe-se que não passou de manuscritos e anotações que também estavam na bagagem, quando naufragou. E a tal epopeia, de que fala a Henriques Leal e que, de acordo com este, estaria escrita, perdeu-se no mar, para o conforto ou desespero. Henriques Leal supóe que junto com os destroços do navio, estariam as malas com os manuscritos, e que alguém se teria apossado para algum dia se vangloriar dos manuscritos ${ }^{27}$, mas conforme a tripulação, o poeta carregava consigo uma mala com chave, que trazia pendurada junto ao pescoço. E sabe-se que o corpo do poeta, envolto nas águas, também ficou pe dido para sempre ${ }^{28}$.

Dos dezasseis cantos, quando os doze primeiros já estavam prontos, apenas Henriques Leal teve o privilégio de os $\operatorname{ler}^{29}$.

Restando apenas quatro cantos de Os Timbiras, com a morte de Gonçalves Dias o indianismo brasileiro atingiu o seu apogeu e logo em seguida acabaria por cristalizar ${ }^{30}$. Mas para Souza Pinto, uma das possíveis explicações para o facto de Gonçalves Dias não ter concluído a obra pode centrar-se na ideia de que já não seriam apreciados poemas longos. ${ }^{31}$

$\mathrm{Na}$ capital do Maranhão, São Luís, os comprovincianos e admiradores erigiram uma estátua em homenagem a Gonçalves Dias; de acordo com Veríssimo, "de sobre o airoso fuste de uma palmeira de marmore, eleva-se a sua debil e melancolica figura de romantico ${ }^{32}$ ", hipersensível, varrido por ondas de comoção, melancólico, negativista. O brasileirismo gonçalvino é o de quem não se despojou das obsessóes da juventude, ou melhor, de quem, nos alvores do Romantismo, se descobria brasileiro na medida em que se mantinha português: o seu carácter "brasileiro" somente o é por não ter renegado as raízes. A sua identidade de brasileiro (pelo menos naquela altura de nossa história) pressupunha necessariamente o conúbio entre a ecologia nativa e a cultura europeia ${ }^{33}$.

Mas o índio não morreu. Gonçalves desenvolve na sua poesia uma espécie de solicitação do humano, porque, afinal, o índio ainda existe entre nós. Trucidado, reduzido a uma população

\footnotetext{
${ }^{27}$ Ackermann 196427.

${ }^{28}$ Bandeira 199856 (a).

${ }^{29}$ Vide nota 365 p. 187.

${ }^{30}$ Souza Pinto 192822.

${ }^{31}$ Souza Pinto 192822.

${ }^{32}$ Veríssimo 1916254.

${ }^{33}$ Moisés 198942.
} 
menos perceptível pelo número do que por viver nos cafundós deste país cómico; mas existe, ressalta Ricardo ${ }^{34}$.

E São Luis, antes denominada "Atenas brasileira", parece seguir-lhe o exemplo: Atenas nunca mais voltou ao tempo de Péricles; em São Luís também não voltaria a encontrar-se um poeta semelhante a Gonçalves ${ }^{35}$, ou aos ilustres conterrâneos do poeta que estáo representados no seu memorial, na capital maranhense.

${ }^{34}$ Ricardo 196455.

35 Veríssimo 1916254. 


\section{Bibliografia}

\section{Ediçóes}

A. Gonçalves Dias (1998), Gonçalves Dias: Poesia e prosa completas. Org. A. Bueno, Rio de Janeiro, Nova Aguilar.

F. Lourenço (2005), Homero, Ilíada. Lisboa, Cotovia. (2003) Homero, Odisséia. Lisboa, Cotovia.

O. Mendes (2008), Virgilio, Eneida. (bilíngüe), Campinas, Unicamp.

A. Silva (1999), Vigilio, Obras de Virgílio. Lisboa, Temas e Debates.

\section{Estudos}

C. Abbeville (1945), História da Missão dos Padres Capuchinos na Ilha do Maranhão e Terras Circunvizinhas; em que se trata das singularidades admiráveis e dos costumes estranhos dos indios habitantes daquele país. Trad. Sérgio Milliet. São Paulo, Livraria Martins.

F. Ackermann (1964), A obra poética de António Gonçalves Dias. São Paulo, Conselho Estadual de Cultura.

T. Adorno, M. Horkheimer (1985), Dialética do Esclarecimento. Rio de Janeiro, Jorge Zahar.

R. H. Almeida (1997), O Diretório dos Índios. Um projeto de "civilização"no Brasil do século XVIII. Brasília, Editora UnB.

A. Amaral (1924), Elogio da mediocridade. Sáo Paulo, Nova Era.

O. Andrade (1999), "The Cannibalist Manifesto", Third Text 46 92-95.

C. A. André (1993), "Luz e penumbra na literatura humanista dos Descobrimentos", Humanismo Português na Época dos Descobrimentos, Coimbra, Institutos de Estudos Clássicos - Centro de Estudos Clássicos e Humanísticos, 217-256. 
(1992), "Morte e vida na Eneida" in W. Medeiros, A. C. André, V. S. Pereira, A Eneida em Contraluz. Coimbra, Instituto de Estudos Clássicos, 23-76.

L. Arão (2007), "A representação do indígena em Huasipungo de Jorge Icaza", Revista de Estudos Literários Terra Roxa e outras terras 9 107-116.

G. Asanha (1984), A Forma Timbira: estrutura e resistência. São Paulo, USP-FFLCH.

E. Auerbach (1986), Mimeses - A representação da realidade na literatura Ocidental. São Paulo, Perspectiva.

M. Bandeira (1998), "A Vida e a Obra do Poeta" in A. Gonçalves Dias, Gonçalves Dias: Poesia e prosa completas. Org. A. Bueno. Rio de Janeiro, Nova Aguilar 13-56 (a).

_ (1998), "A Poética de Gonçalves Dias” in A. Gonçalves Dias, Gonçalves Dias: Poesia e prosa completas. Org. A. Bueno. Rio de Janeiro, Nova Aguilar 57-70 (b).

Bíblia Sagrada (1966), Trad. Missionários Capuchinhos, Lisboa/ Fátima.

C. Blanckaert (1985), Naissance de Ethnologie?: Anthropologie et missions en Amérique XVI-XVIII siècle. Paris, Les Éditions du CERF.

H. Bloom (1991), A angústia da influência: uma teoria da poesia. Lisboa, Cotovia.

M. Bodkin (1965), Archetypal patterns in poetry: psychologicalstudies of imagination. Londres, Oxford University Press 44-55.

G. Bornheim (1993), "Filosofia do Romantismo" in J. Guinsburg, O Romantismo. São Paulo, Editora Perspectiva 75-111

A. Bosi (2001), Dialética da colonização. São Paulo, Companhia das Letras.

— (2004), História concisa da Literatura Brasileira. São Paulo, Cultrix.

(1993), "Imagens do Romantismo no Brasil" in J. Guinsburg, O Romantismo. São Paulo, Editora Perspectiva 239-256 
C. M. Bowra, (1966), "Some characteristics of literary epic" in S. Commager, Virgil. Englewood Cliffs, Prentice Hall 53-61.

A. F. Brandão (1943), Diálogos das grandezas do Brasil. Rio de Janeiro, Dois Mundos.

J. Bremmer (1983), "Scapegoat Rituals in Ancient Greece", Harvard Studies in Classical Philology 87 299-320.

J. P. Brisson (1972), “Le Pieux Énée” Latomus 31 394-412. (1966), Virgile, son temps et le nôtre. Paris, François Maspero.

K. Büchner (1963), Virgílio. Edizione italiana a cura di Mario Bonaria. Brescia, Paideia.

W. A. Camps, (1969), An introduction to Virgil's Aeneid. Oxford, University Press.

A. Candido (1993), Formação da literatura brasileira: momentos decisivos. Volume 2. Belo Horizonte, Editora Itatiaia.

F. Cardim, (1939), Tratados da Terra e da Gente Do Brasil. São Paulo, Companhia Editora Nacional.

R. Carvalho (1931), Estudos brasileiros. Rio de Janeiro, F. Briguiet.

T. Carvalho (2008), Epopéia e anti-epopéia: de Virgílio a Alegre. Coimbra, Imprensa da Universidade de Coimbra.

L. C. Cascudo (2002), Lendas brasileiras. São Paulo, Global Editora.

E. V. Castro (2002), A inconstância da alma selvagem e outros ensaios de antropologia. São Paulo, Cosac Naify Ediçóes.

— (1986), Araweté: os deuses canibais. Rio de Janeiro, Jorge Zahar.

S. Castro (1996), A carta de Pero Vaz Caminha. Porto Alegre, L\&PM Editores.

M. P. Chagas (1866), Ensaios Críticos. Porto, Viúva Moré.

H. Clastres (1978), Terra sem mal: o profetismo tupi-guarani. São Paulo, Editora Brasiliense.

W. Clausen (1995), A commentary on Virgil: Eclogues. Oxford, Clarendon Press. 
(1966), "An interpretation of the Aeneid" in S. Commager, Virgil. Englewood Cliffs, rentice Hall, 75-88.

(1987), Virgil's Aeneid and the tradition of Hellenistic poetry. Berkeley, University of California Press.

A. Coelho da Silva (2006), "Os jogos e as instituições sociais em sociedades arcaicas e primitivas" in F. S. Lessa, R. Bustamante, Memória e festa. Rio de Janeiro, Mauad Editora 157-164.

I. J. Corrêa (2006), "O elixir do pajé, de Bernardo Guimarães", Ciências \& Letras 39 83-102.

A. Costa, (1934), Introdução à arqueologia brasileira: (etnografia e história). São Paulo, Companhia Editora Nacional.

A. Coutinho, E. F. Coutinho (1986), A literatura no Brasil. Vol. III. Rio de Janeiro/Niterói, José Olympio/ EDUFF.

M. C. Cunha (1998), História dos indios no Brasil. São Paulo, Fapesp/Cia das Letras.

I. D'Evreux (1929), Viagem ao Norte do Brasil, feita nos anos de 1613 e 1614. Trad. C. A. Marques, Rio de Janeiro, Liv. Leite Ribeiro.

M. A. Di Cesare (1974), The altar and the city. A reading of Vergil's Aeneid. New York-London, Columbia University Press.

A. Domingues (2000), Quando os indios eram vassalos. Lisboa, Casa da Moeda.

G. Durand (1983), Mito e sociedade: a mitanálise e a sociologia das profundezas. Lisboa, Regra do Jogo.

L. Edelstein (1967), The Idea of progress in classical antiquity. Baltimore, Md. Johns Hopkins Press.

(1966), The meaning of stoicism. Cambridge.

M. Eliade (1963), Aspects Du Mythe. Paris, Gallimard.

(1969), O mito do eterno retorno. Lisboa, Ediçôes 70.

(1970), O Sagrado e o Profano. Lisboa, Livros do Brasil.

T. S. Eliot (1957), On poetry and poets. London, Faber. 
P. S. Enk (1957), “La Tragédie de Didon”, Latomus 16 628-642.

S. Farron (1982), “The abruptness of the end of Aeneid" Acta Classica 25 136-141.

- (1981), "The death of Turnus viewed in the perspective of its historical background", Acta Classica 24 97-106.

_ (1993), Vergil's Aeneid: a poem of grief and love. Leidin, E. J. Brill.

D. C. Feeney (1983), “The Taciturnity of Aeneas", Classical Quarterly 33 204-219.

F. Fernandes (1989), A organização social dos Tupinambá. São Paulo, Hucitec-UnB.

E. Figueiredo (2005), "Por um comparativismo interamericano", Revista de Letras 45-2 15-32.

L. Figueiredo (1949), Indios do Brasil. Paulo, Livraria José Olympio Editora.

P. Franchetti (2007), Estudos de literatura brasileira e portuguesa. Cotia, Ateliê Editorial.

N. Frye (1957), Anatomy of criticism: four essays. Oxford, University Press.

J. M. Gagnebin (1997), Homero e a dialética do esclarecimento. Campinas, Unicamp.

Gabriel Soares (1938), Tratado Descriptivo do Brasil em 1587. São Paulo, Companhia Editora Nacional.

P. M. Gândavo (1922), História da província Santa Cruz a que vulgarmente chamamos Brasil. São Paulo, Melhoramentos.

O. M. Garcia (1956), Luz e fogo no lirismo de Gonçalves Dias. Rio de Janeiro, Livraria São José.

A. Gonçalves Dias (1909), O Brazil e a Oceania. Rio de Janeiro, H. Garnier.

A. P. Graça (1998), Uma Poética do Genocídio. Rio de Janeiro, Topbooks.

B. Gracián (1969), "El Héroe” in El Héroe. El Discreto. Madrid, Espasa-Calpe 3-50. 
P. Grimal (1989), Virgile ou la seconde naissance de Rome. Paris, Flamarion.

S. Gruzinski (2001), O Pensamento Mestiço. São Paulo, Cia. Das Letras.

M. L. S. Guimarães (1988), "Nação e Civilização nos Trópicos: O Instituto Histórico e Geográfico Brasileiro e o Projeto de uma História Nacional”, Estudos Históricos 1 5-27.

T. Haecher (1966), "Odysseus and Aeneas" in S. Commager, Virgil. Englewood Cliffs, rentice Hall 68-74.

S. J. Harrison (1990), Oxford readings in Virgil's Aeneid. Oxford, University Press.

A. Herculano (1998), "Futuro Literário de Portugal e do Brasil" in A. Gonçalves Dias, Gonçalves Dias: Poesia e prosa completas. Org. A. Bueno. Rio de Janeiro, Nova Aguilar, 97-100.

R. A. Hornsby (1970), Patterns of action in the Aeneid: an interpretation of Virgil's epic similes. Iowa City, University of Iowa Press.

F. Huxley (1958), Selvagens amáveis. São Paulo, Companhia Editora Nacional.

R. Jacobbi (1958), Goethe, Shiller, Gonçalves Dias. Porto Alegre, Fac. de Filosofia do Rio rande do Sul.

W. Jaeger (1995), Paidéia: A formação do homem grego. Trad. Artur M. Parreira. São Paulo, Martins Fontes.

P. Jal (1963), La guerre civile a Rome. Paris, Presses Universitaires de France.

L. Jenny (1979), Intertextualidades. Coimbra, Almedina.

W. R. Johnson (1976), Darkness Visible. A study of Virgil's Aeneid. Berkeley, University California Press.

W. F. J. Knight (1966), Roman Vergil. Harmondsworth, Penguin.

B. Knox (1951), Tragic themes in Western literature: seven essays. New Haven, Yale University Press.

K. Kodama (2005), Os filhos das brenhas e o Império do Brasil: A etnografia no Instituto Histórico e Geográfico do Brasil 
(1840-1860). Rio de Janeiro, PUC - Departamento de História.

F. Kothe (1997), O cânone colonial. Brasília: Brasília, Editora da UnB.

(2000), O cânone imperial. Brasília, Editora da UnB.

(1987), O herói. São Paulo, Editora Ática.

A. Kuper (1997), The invention of primitive society. London/New York, Routledge.

M. E. Ladeira (1982), "Uma Aldeia Timbira" in S. C. Novaes, Habitaçôes Indígenas. São Paulo, Editora Nobel 12-31.

J. S. Leopoldi (2002), "Rosseau - Estado de natureza, o "bom selvagem" e as sociedades indígenas", Revista Alceu 4 158-172.

J. Léry (1941), Viagem à terra do Brasil. trad. Int. notas de S. Milliet. São Paulo, Livraria Martins.

A. Lesky (1996), A tragédia grega. Trad. J. Guinsburg, G. Souza, A. Guzik, São Paulo, Editora Perpectiva.

C. S. Lewis (1966), "Virgil and the subject of secondary epic" in S. Commager, Virgil. Englewood Cliffs, Prentice Hall 62-66.

M. M. Longo (2006), "Guerreiros sem canto", Letras de Hoje 4 41-57.

Machado de Assis (1994), "Notícia da atual literatura brasileira. Instinto de nacionalidade" in Obra completa de Machado de Assis. Rio de Janeiro, Nova Aguilar.

J. Madeira (2000), Camóes contra a Expansão e o Império. Lisboa, Fenda.

W. S. Maguiness (1963), "L'inspiration tragique de l'Énéide”, L'Antiquité Classique 32 447-490.

W. J. Marques (2006), "O índio e o destino atroz", Letras \& Letras 22 175-191.

_- (2003), "O poema e a metáfora", Revista Letras 60 79-93, (a).

_ (2003), "Revista e Ruptura”, II COHILILE - Anais 14 1-8 (b). 
C. Martindale (1993), Redeeming the text: Latin poetry and the hermeneutics of reception. Cambridge, Cambridge University Press.

_ (1984), Virgil and its influence. Bristol, Bristol Classical Press.

C. N. Matos (1988), Gentis Guerreiros: O Indianismo de G.D. São Paulo.

W. Medeiros (1992), "A outra face de Eneias" in W. Medeiros, A. C. André, V. S. Pereira, A Eneida em Contraluz. Coimbra, Instituto de Estudos Clássicos, 7-22.

J. C. Melatti (1987), Indios do Brasil. São Paulo, Hucitec - USP.

M. Moisés (1989), História da literatura brasileira. São Paulo, Cultrix.

M. Montaigne (1976), Ensaios. Lisboa, Amigos do Livro.

J. M. Monteiro (1997), Confronto de culturas: conquista, resistência, transformação. Rio de Janeiro, Expressão e Cultura.

— (2001) Tupis, Tapuias e Historiadores: estudos de história Indigena e do Indigenismo. Unicamp (policop.)

M. C. Moutinho (2000), O indígena no pensamento colonial português. Lisboa, Universitárias Lusófonas.

M. Nóbrega (1931), Cartas do Brasil, 1549-1560. Rio de Janeiro, Academia Brasileira de Letras.

A. P. Oliveira (2005), "A corrupção do universo indianista nas "poesias americanas" de Gonçalves Dias", Revista Trama 2 39-57.

O. Orico (1930), Mitos ameríndios: sobrevivências na tradição e na literatura brasileira. Rio de Janeiro, S. Ed.

B. Otis (1964), Virgil. A study in civilized poetry. Oxford, University Press.

J. Overing (1986), "Images of cannibalism, death and domination in a non-violent society", Journal de la Société des Américanistes 72 133-56.

A. Parry (1987), “The two voices of Virgil's Aeneid” in H. Bloom, 
Virgil' Aeneid (Modern critical interpretations). Chelsea House Publishers. 57-73.

O. Paz (1982), "O mundo heroico" in O Arco e a Lira. Trad. O. Savany. Rio de Janeiro, Nova Fronteira 241-266.

V. S. Pereira (1992), "Sementes de frustração na Eneida" in W. Medeiros, A. C. André, V. S. Pereira, A Eneida em Contraluz. Coimbra, Instituto de Estudos Clássicos, 77-132.

J. Perret (1967), "Optimisme et tragédie dans I'Enéide", Révue d' Études Latines 45 342-363.

M. A. C. N. Pizarro (1970), Gonçalves Dias e o drama romântico. Coimbra, M.A.C.N. (policop.).

J. D. Poz Neto (1991), No país dos Cinta Larga: Uma etnografia do ritual. São Paulo, Universidade de São Paulo (policop.).

D. Proença Filho (1969), Estilos de Época na literatura. São Paulo, Liceu.

M. C. J. Putnam (1988), The poetry of the Aeneid. Ithaca/London, Cornell University Press.

K. Quinn (1968), Virgil's Aeneid. A Critical Description. London/ Henley, Routledge \& Kegan Paul.

M. A. Ribeiro (2000), "A carta de Caminha na literatura e na pintura do Brasil e de Portugal: tradiçấo e contradição", Máthesis 9 19-68.

C. Ricardo (1964), O indianismo de Gonçalves Dias. Sáo Paulo, Conselho Est. de Cultura.

P. Ricoeur (1991), "Life in quest of narrative" in D. Wood, On Paul Ricoeur: narrative and interpretation. Londres, Routledge 20-33.

—— (2005), Sobre a Tradução. Lisboa, Cotovia.

A. Rocha (1980), "Epopéia da hora e a epopéia de sempre", Colóquio-letras 58 119-126.

A. D. Rodrigues (1994), Linguas brasileiras: para o conhecimento das linguas indígenas. Rio de Janeiro, Ediçóes Loyola.

S. Romero (1943), História da literatura brasileira. org. e pref. N. 
Romero. 3.ed. aument. Rio de Janeiro, Liv. José Olympio.

L. Roncari (1995), Literatura brasileira: dos primeiros cronistas aos últimos românticos. São Paulo, Edusp.

M. H. Rouanet (1991), Eternamente em berço esplêndido: a fundação de uma literatura nacional. São Paulo, Siciliano.

J. J. Rousseau (1993), Discurso sobre a origem e os fundamentos da desigualdade entre os homens [1755]; Discurso sobre as ciências e as artes [1750]. São Paulo, Martins Fontes.

O. C. Sáez (2007), “Alimento Humano: O Canibalismo e o Conceito de Humanidade", Antropologia em primeira mão 101 1-23.

(2006), "Autobiografia e sujeito histórico indígena”, Novos Estudos 76 179-195.

S. Santiago (2000), Uma literatura nos trópicos: ensaio sobre dependência cultural. Rio de Janeiro, Editora Rocco.

L. M. Schwarcz (1998), As barbas do imperador. São Paulo, Cia das Letras.

J. J. Sebrelli (1991), "Indigenimo, indianismo, el mito del buen salvage em Iberoamérica”, Cuadernos Hispanoamericanos 487 45-68.

A. Seeger (1980), Os indios e nós: estudos sobre sociedades tribais brasileiras. Rio de Janeiro, Campus.

J. S. Silva Dias (1982), Os Descobrimentos e a Problemática Cultural do Século XVI. Lisboa, Editorial Presença.

J. A. Silva Junior (2006), Doces modinhas pra Iaiá, buliçosos lundus pra Ioiô: poesia romântica e música popular no Brasil do século XIX. São Paulo, Fac. de Filosofia, Letras e Ciências Humanas, (policop.).

J. T. P. Simóes, D. Simóes (2005), Novos estudos estilísticos de I-Juca Pirama (Incursóes semióticas). Rio de Janeiro, Dialogarts.

N. W. Sodré (1944), A formação da sociedade brasileira. São Paulo, Livraria José Olympio Editora.

— (1969), História da literatura brasileira. Rio de Janeiro, 
Civilização Brasileira.

M. Souza Pinto (1931) Gonçalves Dias em Coimbra. Coimbra, Coimbra Ed.

_- (1928), O indianismo na poesia brasileira. Coimbra.

H. P. Stahl (1981), “Aeneas - na 'unheroic' hero?”, Arethusa 14 157-177.

A. The et (1944), Singularidades da França Antarctica, a que outros chamam de América. São Paulo, Companhia Editora Nacional.

F. Tinland (1968), L'homme sauvage - Homo ferus et homo sylvestris. Del'animal à l'homme. Paris, Payot.

T. Todorov (1999), A conquista da América: a questão do outro. Trad. B. Moisés. 2a ed. São Paulo, Martins Fontes.

C. P. Valverde (1997), "Don Juan Valera y El indianismo romântico brasileño", Cuadernos Hispanoamericanos 570 107-123.

J. M. P. Vasconsellos (1868), Selecta Brasiliense. Universal de Laemmert (Digit. Harvard University, 2007)

R. Ventura (1991), Estilo tropical: história cultural e polêmicas literárias no Brasil. São Paulo, Cia das Letras.

J. Veríssimo (1916), História da literatura brasileira. Rio de Janeiro, Livraria Francisco Alves.

A. Vilaça (1998), "Comendo como gente: Formas do canibalismo wari' à luz do perspectivismo", Revista de Antropologia 41 $9-67$.

B. Villalta (1948), Antropofagía ritual americana. Buenos Aires, Emecé.

D. S. Wiesen (1973), "The pessimism of the eighth Aeneid", Latomus 32 737-765.

G. Williams (1983), Tecnique and ideas in the Aeneid. New Haven/London, Yale University Press.

R. Williams (1969), Cultura e sociedade. São Paulo, Editora Nacional. 
R. D. Williams (1992), Aeneas and the Roman hero. Victoria, Nelson.

—, (1987), The Aeneid. London, Allen \& Unwin.

J. R. Wilson (1969), "Action and emotion in Aeneas", Greece \& Rome n. s. 16 67-75.

M. Worton, J. Still (1990), Intertextuality: theories and practices. Manchester; New York, Manchester University Press. 


\section{Volumes publicados na ColecÇÃo "Varia” - SÉRIE MoNogRafiaS}

1. Mariana Montalvão Matias, Paisagens naturais e paisagens da alma no drama senequiano. "Troades" e "Th estes" (Coimbra, CECH, 2009).

2. João Paulo Barros Almeida, Sentimento e conhecimento na poesia de Camilo Pessanha (Coimbra, CECH, 2009).

3. Cristina Santos Pinheiro, Opercurso de Dido, rainha de Cartago, na Literatura Latina (Coimbra, CECH, 2010).

4. Ricardo Nobre, Intrigas Palacianas nos Annales de Tácito. Processos e tentativas de obtenção de poder no principado de Tibério (Coimbra, CECH/CEC, 2010).

5. Weberson Fernandes Grizoste, A dimensão anti-épica de Virgílio e o indianismo de Gonçalves Dias (Coimbra, CECH, 2011). 
Impressão:

Simões \& Linhares, Lda.

Av. Fernando Namora, n. ${ }^{\circ} 83$ Loja 4 3000 Coimbra 

Pelo lado épico, Virgílio celebra a glória e a honra dos romanos; mas pelo lado trágico celebra, com lágrimas, os fatigados momentos que os precursores da nação romana se viram obrigados a enfrentar. Aqui veremos as marcas fundamentais da Eneida no indianismo de Gonçalves Dias, nas suas linhas de continuidade e intertextualidade que o poeta, embora o desejasse, não lhe foi possível evitar. Em momento algum Gonçalves demonstra o seu apreço por uma epopeia de lágrimas e de dores. A sua proposta era um "génesis americano", uma "Ilíada Brasileira", "criação recriada", mas o que nos deixa realmente é uma "Eneida Brasileira", uma epopeia inacabada. 